\title{
Uloga kognitivnih i motivacijskih činitelja u predviđanju konstruktivne komunikacije prilikom sukoba u bliskim vezama
}

\section{Krznarić Jaković, Tina}

Doctoral thesis / Disertacija

2020

Degree Grantor / Ustanova koja je dodijelila akademski / stručni stupanj: University of Zagreb, University of Zagreb, Faculty of Humanities and Social Sciences / Sveučilište u Zagrebu, Filozofski fakultet

https://doi.org/10.17234/diss.2020.203119

Permanent link / Trajna poveznica: https:/urn.nsk.hr/urn:nbn:hr:131:723963

Rights / Prava: In copyright/Zaštićeno autorskim pravom.

Download date / Datum preuzimanja: 2023-04-26

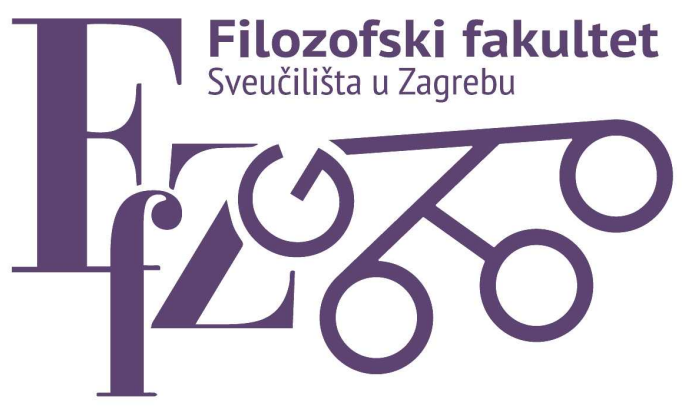

Repository / Repozitorij:

ODRAZ - open repository of the University of Zagreb

Faculty of Humanities and Social Sciences
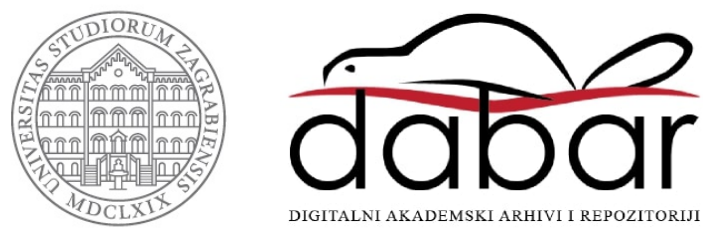


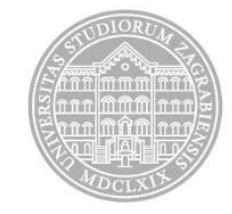

Sveučilište u Zagrebu

Filozofski fakultet

Tina Krznarić Jaković

\section{ULOGA KOGNITIVNIH I MOTIVACIJSKIH ČINITELJA U PREDVIĐANJU KONSTRUKTIVNE KOMUNIKACIJE PRILIKOM SUKOBA U BLISKIM VEZAMA}

DOKTORSKI RAD

Mentor: Dr. sc. Željka Kamenov, red. prof.

Zagreb, 2020. 



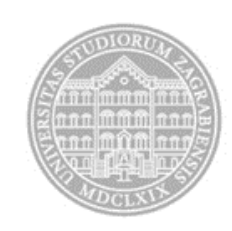

Sveučilište u Zagrebu

Faculty of Humanities and Social Sciences

Tina Krznarić Jaković

\section{THE ROLE OF COGNITIVE AND MOTIVATIONAL FACTORS IN PREDICTING CONSTRUCTIVE COMMUNICATION DURING CONFLICTS IN CLOSE RELATIONSHIPS}

DOCTORAL THESIS

Supervisor: Željka Kamenov, PhD

Zagreb, 2020. 



\section{ZAHVALE}

Hvala svima koji su mi pomogli u izradi ovog rada. Prije svega želim zahvaliti mentorici, prof. dr. sc. Željki Kamenov što me uvela u svijet znanosti i cijelim putem mi pružala podršku svojom iznimnom stručnošću.

Zahvaljujem i članovima povjerenstva za praćenje mog napretka na doktorskom studiju, te prof. dr. sc. Damiru Ljubotini na stručnoj i prijateljskoj potpori kada mi je ona bila najpotrebnija. Zahvaljujem dr. sc. Aleksandri Huić na korisnim sugestijama i konstruktivnim prijedlozima, te dr. sc. Ivanu Tomiću na znanju i spremnosti da pomogne u bilo koje doba. Hvala studentima psihologije na pomoći u pripremi i provedbi istraživanja, kao i sudionicima istraživanja na uloženom vremenu i trudu.

Veliko hvala kolegicama i prijateljicama Jeleni i Lani na bezrezervnoj podršci i spremnosti na razgovor kad god je bilo potrebno.

Ove radnje ne bi bilo bez podrške mojih roditelja, koji su uvijek vjerovali u mene i podupirali me, na čemu im veliko hvala. Hvala i Borisu za svu podršku tijekom cijelog doktorskog studija i što je uvijek bio uz mene, kao i mojim prijateljima koji su se uvijek veselili mojim uspjesima. Hvala i mojoj Eleni na strpljivosti tijekom završnih tjedana rada na doktoratu, te što je predstavljala dodatnu motivaciju za završetak ovog rada. 


\section{O MENTORICI}

Prof. dr. sc. Željka Kamenov zaposlena je kao redovita profesorica u trajnom zvanju na Katedri za socijalnu psihologiju Odsjeka za psihologiju Filozofskog fakulteta Sveučilišta u Zagrebu. Nastavnica je na preddiplomskom, diplomskom, specijalističkom i doktorskom studiju psihologije u okviru kojih vodi kolegije: Socijalna percepcija i stavovi, Neeksperimentalna psihologijska metodologija, Socijalna kognicija, Komunikacijske vještine, Psihologija roda i spola, Psihologija partnerskih odnosa, Kognitivna socijalna psihologija, Suvremeni pristupi istraživanjima bliskih odnosa. Kao nastavnica iz područja socijalne psihologije, metodologije istraživanja i komunikacijskih vještina surađuje i na doktorskim studijima glotodidaktike, kineziologije i socijalnog rada. Zajedno s prof. dr. sc. Vesnom Vlahović-Štetić dobitnica je državne Nagrade Ivan Filipović za doprinos visokom školstvu u RH.

Njeni istraživački i stručni interesi usmjereni su na područje socijalne kognicije (pojam o sebi i drugima, atribucijski procesi, samoregulacija, kognitivni pristup stereotipima, stavovi, stigmatizacija, rodne uloge i stereotipi) kao i na područje bliskih odnosa (privrženost u odrasloj dobi; ljubavni, prijateljski i obiteljski odnosi u odrasloj dobi). Vodila je niz domaćih i međunarodnih znanstvenih projekata, među kojima su „Uloga socio-kognitivnih procesa u samoregulaciji i interpersonalnim odnosima“, „Percepcija, iskustvo i stavovi o rodnoj diskriminaciji u RH“, „Nacionalni i europski identitet“, „,Rodne, generacijske i kulturalne razlike u izražavanju ljubavi među bračnim partnerima“, „Manjinski stres i mentalno zdravlje osoba homoseksualne i biseksualne orijentacije u Hrvatskoj“ te „Obilježja partnera i njihove međusobne interakcije koja doprinose održavanju kvalitetnih partnerskih odnosa u kontekstu destabilizacijskih izazova u suvremenom društvu“".

Pod njenim mentorstvom izrađeno je i obranjeno više od 100 diplomskih radova, dva znanstvena magistarska rada, dva specijalistička rada iz kliničke psihologije i 11 doktorskih disertacija. Objavila je više od 50 izvornih znanstvenih radova, urednica je i koautorica 7 znanstvenih knjiga, koautorica je udžbenika iz psihologije za gimnazije, napisala je dva stručna priručnika te uredila tri knjige sažetaka sa znanstvenih skupova. Održala je desetak pozvanih predavanja i podnijela više od 140 priopćenja na međunarodnim i domaćim znanstvenim i stručnim skupovima.

Članica je Hrvatskog psihološkog društva, Hrvatske psihološke komore, Hrvatskog udruženja za bihevioralno-kognitivne terapije, Društva za psihološku pomoć, International Association for Relationship Research te Society for Personality and Social Psychology. 


\section{SAŽETAK}

Cilj ovog istraživanja bio je ispitati ulogu kognitivnih i motivacijskih odrednica konstruktivne komunikacije pri rješavanju sukoba u intimnim vezama, odnosno provjeriti može li se konstruktivna komunikacija prilikom sukoba predvidjeti korištenjem modela Teorije planiranog ponašanja. Namjera ponašanja najbolji je prediktor stvarnog kasnijeg ponašanja, a Teorija planiranog ponašanja definira da su za formiranje namjere ključni stav prema ponašanju, socijalna norma izvođenja ponašanja, te percipirana bihevioralna kontrola nad ponašanjem. Vremenska perspektiva i atribucijski stil, kao stabilne karakteristike pojedinca, utječu na formiranje stavova, uvažavanje socijalnih normi te percepciju bihevioralne kontrole nad izvođenjem ponašanja, ali i na samu komunikaciju prilikom sukoba. Stoga nas je zanimalo doprinose li vremenska perspektiva i atribucijski stil, uz elemente koje postulira Teorija planiranog ponašanja, boljem predviđanju ponašanja osoba prilikom sukoba. Provedeno je istraživanje u dvije vremenske točke na uzorku od 240 sudionika mlađe odrasle dobi koji su u trenutku provedbe istraživanja bili u ljubavnoj vezi, ali ne i u braku. U prvoj vremenskoj točki ispitani su stavovi o konstruktivnoj komunikaciji, socijalna norma konstruktivne komunikacije, percipirana bihevioralna kontrola nad konstruktivnom komunikacijom prilikom sukoba, namjera buduće konstruktivne komunikacije, vremenska perspektiva te atribucijski stil sudionika. Mjesec dana kasnije uslijedila je druga točka mjerenja u kojoj ispitana stvarna konstruktivna komunikacija prilikom sukoba u proteklih mjesec dana. Metodologijom strukturalnog modeliranja provjereno je pristajanje podataka modelu koji postulira Teorija planiranog ponašanja, te pristajanje podataka proširenom modelu koji uključuje vremenske perspektive, atribuiranja partnerovog negativnog ponašanja i atribucijski stil. Rezultati pokazuju da je konstruktivnu komunikaciju prilikom sukoba moguće predvidjeti modelom definiranim Teorijom planiranog ponašanja, te da stav o ponašanju, socijalna norma i bihevioralna kontrola ne predviđaju konstruktivnu komunikaciju izravno, već posredno preko namjere konstruktivne komunikacije. Osobe koje izražavaju pozitivniji stav prema konstruktivnoj komunikaciji, koje drže da okolina od njih očekuje da komuniciraju na taj način te koje smatraju da su u stanju komunicirati konstruktivno ako to žele, izražavaju veću namjeru budućeg konstruktivnog komuniciranja prilikom sukoba, te posljedično uistinu i komuniciraju više konstruktivno prilikom sukoba s partnerom. Uključenjem vremenskih perspektiva, atribuiranja partnerovog negativnog ponašanja i atribucijskog stila $u$ model, povećava se prediktivnost modela za konstruktivnu komunikaciju prilikom sukoba, ukazujući na važnu ulogu ovih konstrukata u razumijevanju dinamike bliskih odnosa. Istraživanje daje doprinos 
razumijevanju kognitivnih i motivacijskih činitelja kao prediktora konstruktivne komunikacije prilikom sukoba u intimnoj vezi, posebno u segmentu njihova međuodnosa. Dobiveni nalazi, predstavljaju teorijski i metodološki doprinos ovom području, a imaju i važne praktične implikacije za razumijevanje partnerskih odnosa.

Ključne riječi: bliske veze, komunikacija prilikom sukoba u vezi, Teorija planiranog ponašanja, vremenska perspektiva, atribucijski stil, atribuiranje partnerovog negativnog ponašanja 


\section{SUMMARY}

\section{Introduction}

Conflicts occur occasionally in every close relationship and they are inevitable. But the way people communicate during these conflicts is predictive for relationship quality, satisfaction and relationship dissolution. The usual ways in which one communicates during relationships conflicts is called a communication pattern. Some patterns help resolve conflicts, while other patterns intensify conflicts. The constructive communication pattern involves both partners equally in resolving the conflict or stress within the relationship. It refers to a pattern whereby one couple member engages in joint problem solving and mutual disclosure during a conflict situation with the other couple member. Since constructive communication is an intentional behavior, it is plausible that the Theory of planned behavior (TPB) model (Ajzen \& Fishbein, 1977) predicts such behavior. According to the TPB, behaviors can be predicted by behavioral intent which is formed based on attitudes toward the specific behavior, the social norm associated with the behavior and the perceived behavioral control to perform the behavior. Since attitudes, social norm and perceived behavioral control are guided by other cognitive and motivational processes, it is expected that one's time perspective and attributional style should help in understanding relationship communication. Thus, the main goal of this study was to investigate whether constructive communication during conflicts can be predicted using the TPB and to determine if expanding the model by including time perspectives and attributional style improves this prediction.

\section{Methodology}

The sample consisted of 240 young adults, aged between 18 and 30, who were in a serious relationship but not married. The research was conducted in two time points. In the first, elements of the TPP (attitudes towards constructive communication, social norm for such behavior, and perceived behavioral control over constructive communication during conflicts) were assessed using a questionnaire constructed according to Ajzen's (2011) guidelines specifically for this study. Time perspectives (Zimbardo's Time Perspective Inventory, ZTPI, Zimbardo \& Boyd, 1999), attributional style (Attributional Style Questionnaire, ASQ, Peterson, Semmel, Von Baeyer, Abramson, Metalsky, \& Seligman, 1982) and attributions of partner's negative behavior (Relationship Attribution Measure, RAM, Fincham \& Bradbury, 1992) were also assessed. A month later, actual constructive communication during conflicts in the past month were measured using the Communication Patterns Questionnaire's (CPQ) Constructive Communication subscale (Christensen \& Sullaway, 1984). Using structural equation 
modelling, two models were tested: the basic TPB model, and the extended TPB model which included time perspectives, attributional style and attributions of partner's negative behavior.

\section{Results and discussion}

The results revealed that constructive communication during conflicts can be predicted using the TPB's model. A more positive attitude towards constructive communication, a stronger social norm for communicating constructively and higher perceived behavioral norm were associated with a stronger intent to communicate constructively in future conflicts. Behavioral intent predicted actual constructive communication during conflicts. Attitudes, social norm, and perceived behavioral control did not have a direct effect on constructive communication, but rather an indirect one through behavioral intent. Examining the extended model, in which time perspectives, attributional style and attributions of partner's negative behavior were included in the TPB model, it was shown that the extended model improved the prediction of constructive communication compared to the basic TPB model. Past positive and negative time perspectives predicted subjective norm, and present fatalistic time perspective was associated directly with lower behavioral intent to communicate constructively. Those more oriented towards the past showed a stronger norm for constructive communication, although those focused on negative aspects of their past believed they were not able to communicate constructively. Lower behavioral intent was predicted by present fatalistic time perspective, which is in line with previous findings indicating present fatalistic oriented individuals generally tend to underestimated their behavioral intent in self -report measures (Van Ittersum, 2012). Perceived behavioral control was also associated with attributional style's stability dimension. The stability dimension of attributions of partner's negative behavior had a direct effect on constructive communication, as well as an indirect one through attitudes towards constructive communication. Assigning blame to the partner for what he did (dimension of blame in the attributions of partner's negative behavior) had only an indirect effect on constructive communication through perceived behavioral control. Therefore, we can say that those who believe their partner's negative behavior was caused by a one-time only cause as well as those who do not blame their partner for what he did are more likely to communicate constructively.

\section{Conclusion}

The present research contributes to better understanding of intimate relationship conflicts and communication, as well as their antecedents. A deeper understanding of the cognitive and motivational basis of constructive communication, through attitudes, social norm, 
perceived behavioral control, behavioral intent and factors influencing them provides one of the preconditions for the integration of these constructs into a model that not only broadens the theoretical knowledge of the field, but is also applicable in everyday life couple's therapy and interventions. Indirectly, the research fuels further advancement in the study providing interesting directions for future research.

Keywords: intimate relationships, communication during conflicts in close relationships, Theory of planned behavior, time perspectives, attributional style, attributions of partner's negative behavior 


\section{Sadržaj}

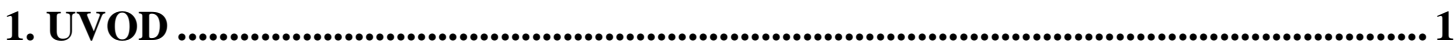

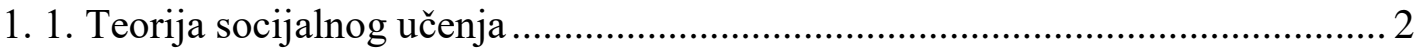

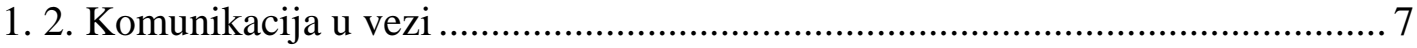

1. 2. 1. Obrasci komunikacije prilikom sukoba .............................................. 11

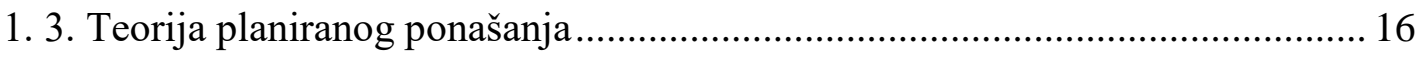

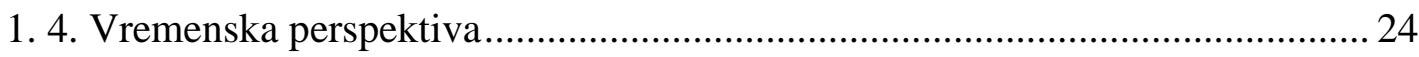

1.4.1. Vremenska perspektiva i bliski odnosi .................................................. 28

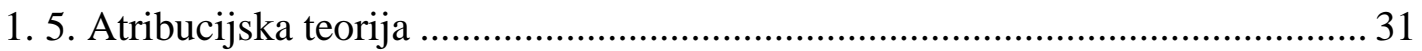

1. 5. 1. Atribuiranje partnerovog ponašanja ....................................................... 33

2. CILJ, PROBLEMI I HIPOTEZE ISTRAŽIVANJA........................................... 39

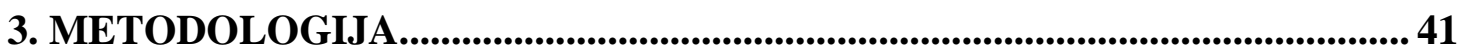

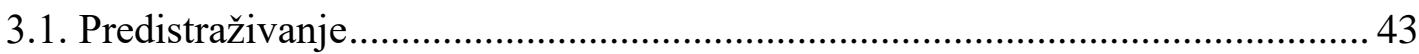

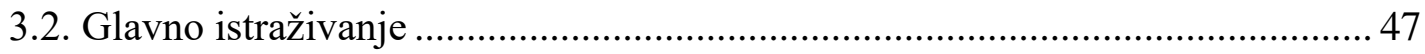

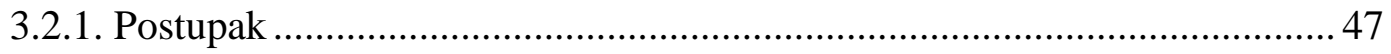

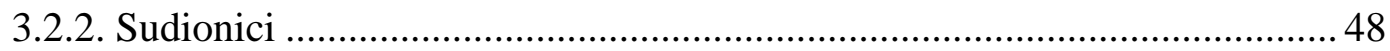

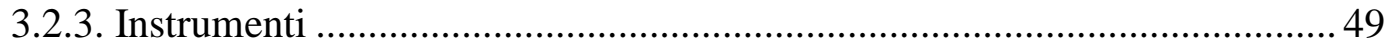

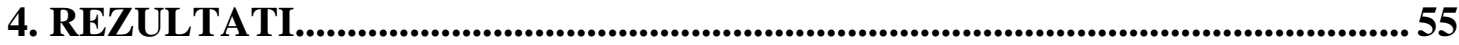

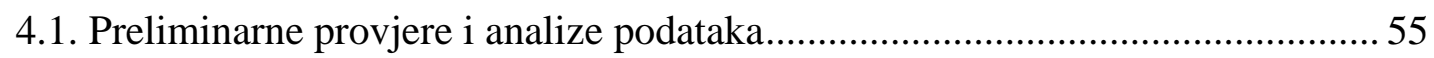

4.1.1. Analiza i tretman podataka koji nedostaju .............................................. 55

4.1.2. Univarijatna i multivarijatna odstupanja rezultata ...................................56

4.1.3. Deskriptivni rezultati i normalitet distribucija ..........................................5 57

4.1.4. Bivarijatne povezanosti među kompozitnim varijablama..........................59

4.2. Provjera modela teorije planiranog ponašanja za predviđanje konstruktivne komunikacije prilikom sukoba metodologijom strukturalnog modeliranja.............. 65

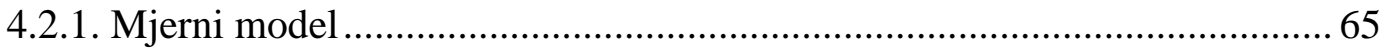

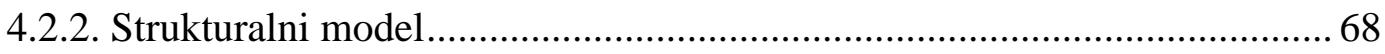


4.3. Proširenje modela teorije planiranog ponašanja dimenzijama atribucija i

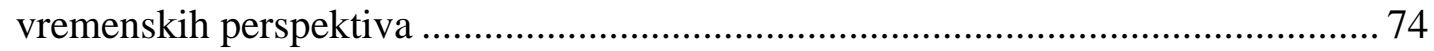

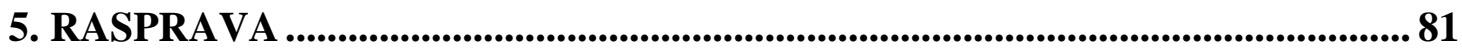

5.1. Učinci stava, subjektivne norme i percipirane bihevioralne kontrole na namjeru konstruktivne komunikacije prilikom sukoba u intimnoj vezi

5.2. Vremenska perspektiva, atribucijski stil i atribuiranje partnerovog negativnog ponašanja $u$ kontekstu teorije planiranog ponašanja............................................ 85

5.3. Metodološka ograničenja i smjernice za buduća istraživanja.......................... 92

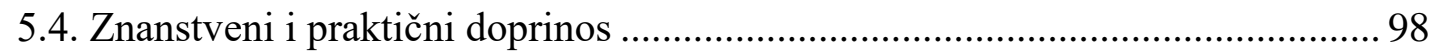

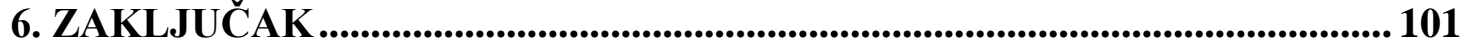

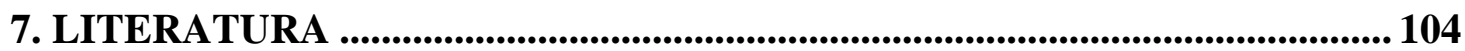

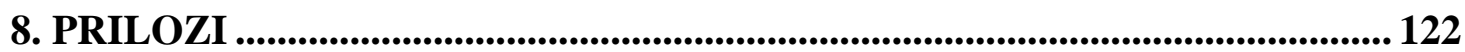

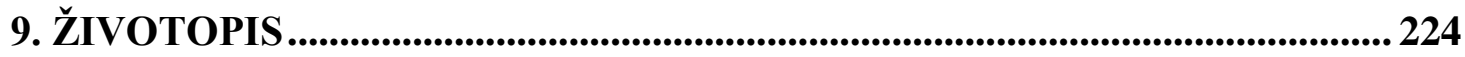

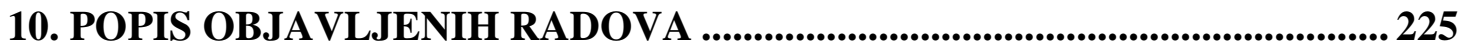




\section{UVOD ${ }^{1}$}

Sukobi su neizbježan dio bliskih odnosa. U svakom bliskom odnosu u nekom trenutku dođe do sukoba, no ono što je bitno za kvalitetu odnosa je način na koji se sukob rješava. Naime, načini rješavanja sukoba su povezani sa zadovoljstvom i kvalitetom braka, a ujedno su i prediktivni za razvod, odnosno prekid veze (Gottman i Levenson, 2000). Uobičajene načine komunikacije nazivamo stilovima ili obrascima komunikacije (Sullaway i Christensen, 1983). Neki omogućavaju rješavanje sukoba, a neki sukobe produbljuju. Prema Christensenu i Shenku (1991) postoje tri stila komunikacije: obrazac konstruktivne komunikacije, obrazac uzajamnog izbjegavanja rasprave i suzdržavanja, te obrazac zahtijevanja promjene i povlačenja, u kojem možemo uočiti obrazac ženskog zahtijevanja i muškog povlačenja te obrazac muškog zahtijevanja i ženskog povlačenja. Konstruktivno rješavanje sukoba karakteriziraju otvorena rasprava o konfliktnim temama, slobodno i pozitivno izražavanje emocija te zajednički trud oko postizanja rješenja u sukobu, a pozitivno je povezano sa zadovoljstvom brakom (Bodenmann, Kaiser, Hahlweg i Fehm-Wolfsdorf, 1998; Heavey, Larson, Zumtobel i Christensen, 1996).

Ovaj rad bavi se predviđanjem konstruktivne komunikacije prilikom sukoba u vezi temeljem elemenata postuliranih Teorijom planiranog ponašanja, odnosno stava prema konstruktivnoj komunikaciji prilikom sukoba, norme konstruktivne komunikacije te percipirane bihevioralne kontrole (Ajzen, 2011). Svrha ovog rada je i poboljšati prediktivnost modela definiranog Teorijom planiranog ponašanja, proširujući ga atribucijskim stilom, atribucijskim stilom vezanim uz vezu te vremenskim perspektivama.

Uvodni dio ovog rada organiziran je u pet cjelina. Prvi dio predstavlja Teoriju socijalnog učenja, polazišnu teoriju za razumijevanje bliskih odnosa, pa tako i komunikacije prilikom sukoba u bliskim vezama. Sadrži povijesni pregled razvoja ove teorije, te njenih implikacija za kvalitetu i zadovoljstvo odnosom, ali i ponašajnih posljedica koje iz nje proizlaze. Prikazana su i neka za temu važna istraživanja bliskih odnosa utemeljena na ovoj teoriji.

Drugi dio uvoda bavi se komunikacijom u bliskim odnosima, te su prikazane definicije komunikacije i predstavljeni neki modeli komunikacije u partnerskim odnosima, kao što je model negativne konfrontacije (Gottman i Krokoff, 1989). Opisana su ključna istraživanja

\footnotetext{
${ }^{1}$ Istraživanje je provedeno u sklopu projekta „Razvoj novog modela komunikacije prilikom sukoba u bliskim vezama“(voditeljica: Tina Krznarić Jaković). Projekt je financiran sredstvima Europskog socijalnog fonda ( $85 \%$ sredstava) te proračunskih sredstava putem Ministarstva znanosti, obrazovanja i sporta (15\% sredstava), kroz natječaj „Istraživačke stipendije za profesionalni razvoj mladih istraživača i poslijedoktoranada““.
} 
komunikacije i njihovih korelata, implikacija i posljedica za odnos. Prikazan je i povijesni razvoj istraživanja komunikacije u partnerskim odnosima, s posebnim naglaskom na komunikaciju prilikom sukoba. Detaljno je su prikazani stilovi komunikacije prilikom sukoba Christensena i Shenka (1991), budući da konstruktivna komunikacija prilikom sukoba operacionalizirana prema njihovim postavkama predstavlja ciljno ponašanje ovog istraživanja. U ovom dijelu uvoda prikazani su i smjerovi razvoja metodologije te postojeći instrumenti za mjerenje komunikacije prilikom sukoba.

U trećem dijelu uvoda predstavljena je Teorija planiranog ponašanja (Ajzen i Fishbein, 1977) koja predstavlja osnovu ovog rada za predviđanje konstruktivne komunikacije prilikom sukoba. Opisan je povijesni razvoj spomenute teorije, njeni dijelovi, ali i određeni nedostaci.

U četvrtom i petom dijelu uvoda naglasak je na konceptima kojima se u ovom radu proširuje model postuliran Teorijom planiranog ponašanja, odnosno vremenskim perspektivama i atribucijskim stilom. Vremenska perspektiva, kojom se ovaj rad bavi u četvrtom dijelu uvoda, je spontani proces kategorizacije doživljaja sebe, svijeta i međuljudskih odnosa u prošlost, sadašnjost ili budućnost, a temeljem kognitivnih procesa utemeljenih na vremenu (Keough, Zimbardo i Boyd, 1999). Definirano je i opisano pet faktora vremenskih perspektiva (prošlost- negativna, prošlost- pozitivna, sadašnjost- hedonistička, sadašnjostfatalistička te budućnost), njihove poveznice s drugim psihološkim konstruktima te ponašajne posljedice. Poseban naglasak stavljen je na opis važnosti razumijevanja vremenskih perspektiva u kontekstu bliskih odnosa, s posebnim naglaskom na partnersku komunikaciju i sukobe.

U petom dijelu uvoda pruža se povijesni pregled razvoja Atribucijske teorije (Weiner, 1983), te istraživanja bliskih odnosa koja iz nje proizlaze. Poseban naglasak je stavljen na atribuiranje partnerovog ponašanja i važnost razumijevanja ovog koncepta za predikciju ishoda veze, te ponašanja u vezi. Opisana je i racionala uključivanja općenitog atribucijskog stila i atribucijskog stila vezanog uz vezu kao elemenata proširenja Teorije planiranog ponašanja za predikciju konstruktivne komunikacije prilikom sukoba u bliskim vezama.

\section{1. Teorija socijalnog učenja}

Teorija socijalnog učenja proizlazi iz biheviorizma, kao i srodna Teorija socijalne razmjene. Obje sugeriraju da je za stabilnost odnosa i zadovoljstvo vezom ključan omjer nagrada i gubitaka u vezi. Ako nagrade premašuju gubitke, osoba će biti sklona nastaviti odnos. No, dok Teorija socijalne razmjene nagradama i gubicima smatra sve što pojedinac procjenjuje 
dobrim ili lošim aspektima partnerskog odnosa, Teorija socijalnog učenja nagrade i gubitke definira u terminima ponašanja koja partneri razmjenjuju u interakcijama. Ponašanje jednog partnera može biti kažnjavajuće ili nagrađujuće za drugog partnera, što dovodi do nagrađujućeg ili kažnjavajućeg odgovora na to isto ponašanje (Bradbury i Karney, 2014). Osnovna premisa teorije socijalnog učenja jest da razmjena nagrađujućih ponašanja pridonosi kvaliteti veze, a da razmjena kažnjavajućih ponašanja šteti vezi (Weiss, Hops i Patterson, 1973). Ovakav naglasak na ponašanje u Teoriji socijalnog učenja rezultat je praktičnih izazova s kojima su se susretali bračni terapeuti 1970-ih godina i njihove potrebe za osmišljavanjem primjenjivih intervencija (Jacobson i Margolin, 1979). Naime, uočeno je da se nezadovoljni parovi najčešće žale upravo na komunikaciju, odnosno prisutnost čestih svađa koje se uvijek iznova ponavljaju u vezi istih tema, ili izostanak kvalitetne i pozitivne komunikacije. Iako drugi teorijski pristupi mogu pružiti objašnjenje zašto se partneri sukobljavaju oko određenih tema, Teorija socijalnog učenja je objasnila što se tijekom sukoba događa te ponudila alate razrješavanja sukoba.

Kelley i sur. (1983) ističu da su interakcije, odnosno razmjena ponašanja, jedini način na koji partneri djeluju jedan na drugoga. Iz svake razmjene ponašanja partneri uče o kvaliteti svoje veze te formiraju očekivanja o budućim ponašanjima partnera. Kada partneri međusobno razmjene nagrađujuća ponašanja, uče da se mogu pouzdati jedno u drugo, da su u stanju adekvatno komunicirati, te da ih partner cijeni, voli i poštuje. Posljedično, njihovo zadovoljstvo vezom raste, što povećava vjerojatnost budućih razmjena pozitivnih ponašanja. Međutim, razmjena kažnjavajućih ponašanja postepeno narušava zadovoljstvo vezom, jer zbog takvih interakcija partneri počinju sumnjati u sposobnost kvalitetne komunikacije kao para, zaključuju da ih partner ne cijeni i ne poštuje, što dalje dovodi do smanjenja zadovoljstva vezom. Kako se smanjuje zadovoljstvo vezom, tako raste vjerojatnost da će buduće interakcije biti negativne. Stoga, Teorija socijalnog učenja opisuje ciklički odnos između ponašanja i zadovoljstva vezom (Slika 1). 


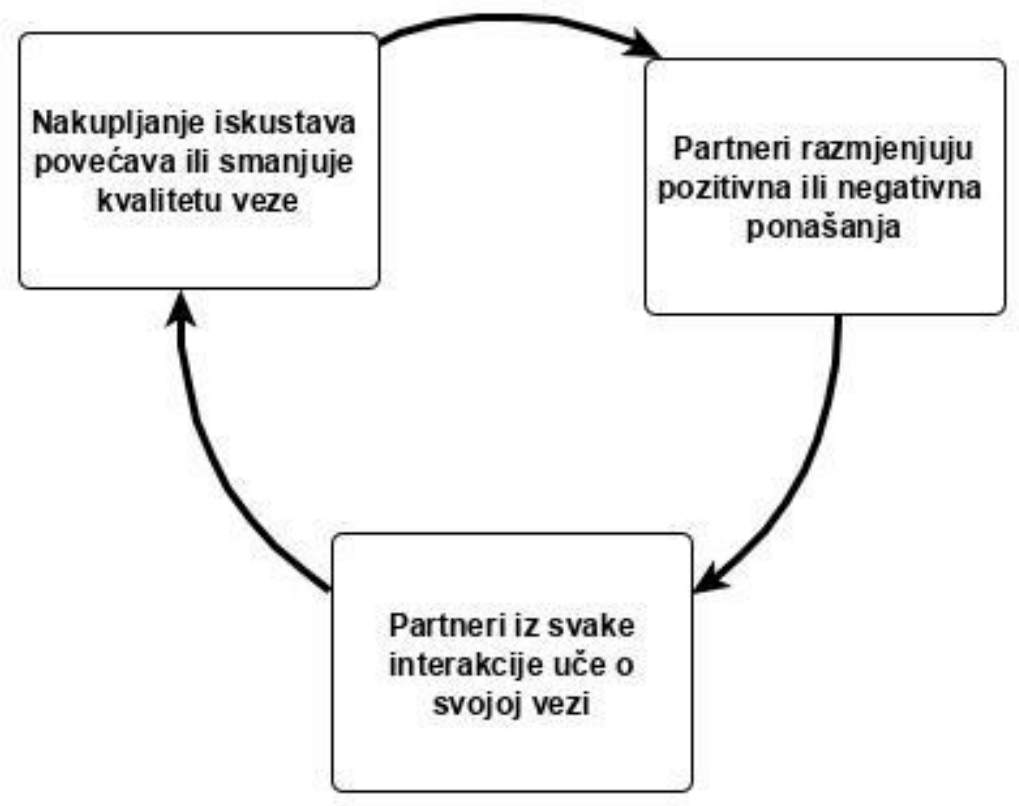

Slika 1. Shematski prikaz Teorije socijalnog učenja u kontekstu bliskih veza (prilagođeno prema Bradbury i Karney, 2014)

Pozitivna komunikacija predstavlja nagrađujuće ponašanje jer vodi rješavanju sukoba, istovremeno partneru šaljući poruku uvažavanja. Opisanim mehanizmom jača vezu i povećava zadovoljstvo vezom oba partnera te povećava vjerojatnost da će i buduća komunikacija biti pozitivna, odnosno konstruktivna. No, postavlja se pitanje zašto se partneri upuštaju u kažnjavajuća, negativna ponašanja kao što su međusobno vrijeđanja, omalovažavanje, vikanje i slično, ako ona toliko štete vezi. Bihevioristički aspekt Teorije socijalnog učenja očituje se u tvrdnji da se pojedinci upuštaju samo u ona ponašanja koja su ranije potkrijepljena ili na neki način nagrađena. Kako je primarni izvor potkrepljenja i nagrada u bliskim vezama partner, to znači da će osoba ponavljati u interakcijama ona ponašanja koja su ranije bila potkrepljena od strane partnera (Bradbury i Karney, 2014). Patterson i Hops (1972) su formirali Teoriju prisile, koja proizlazi iz Teorije socijalnog učenja, a objašnjava da se negativna ponašanja u bliskim odnosima održavaju putem potkrepljenja takvog ponašanja koje partner nesvjesno daje. Teorija prisile pruža uvjerljivo objašnjenje negativnih obrazaca komunikacije u vezi. Primjerice, jedan partner želi da drugi partner nešto učini (npr. iznese smeće), te stoga ljubazno zamoli partnera da to učini. Kada partner ne ispuni zahtjev, prvi partner će ponovno zamoliti, te ukoliko ni tada drugi partner ne ispuni zadatak, uslijedit će prigovaranje, povišenje tona glasa, a možda i svađa. Naposljetku, partner će ispuniti zadatak kako bi prekinuo prigovaranje ili svađu, čime je potkrijepio partnera za buduće prigovaranje ili povišenje tona. Zbog takvog nesvjesnog 
potkrepljenja raste vjerojatnost da će u budućoj sličnoj situaciji partner pribjeći sličnim metodama, budući da je iz opisane interakcije naučio da je to put kojim dobije ono što je tražio. Srodan pristup opisanom je uvjetovanje bijega koje definiraju Gottman i Levenson (1986). Uvjetovanje bijega je pristup koji opisuje da potkrepljenje ponašanja predstavlja i prestanak neugodnog podražaja. Ovaj model objašnjava zašto se u nekim vezama prilikom sukoba iznova pojavljuju i negativna ponašanja koja nikako ne dovode do razrješenja sukoba. Ukoliko se par svađa, te svađa traje prilično dugo, to zasigurno predstavlja neugodan podražaj za oba partnera. No, ako se jedan partner rasplače, baci tanjur u zid ili napusti prostoriju, svađa će vjerojatno odmah prestati. Iako takva ponašanja nikako ne vode rješenju problema, kratkoročno gledano partner koji je izveo takvo ponašanje uklonio je negativan podražaj svađe. Time je dobio potkrepljenje za takvo negativno ponašanje, te je vjerojatnije da će u sličnoj situaciji u budućnosti pribjeći jednakom obrascu. Iako su takva ponašanja, koja u ekstremnom obliku predstavljaju i partnersko nasilje, iznimno štetna za vezu, kratkoročne nagrade koje pružaju čine ih iznimno teškima za mijenjanje (Bradbury i Karney, 2014).

Teoretičari u području Teorije socijalnog učenja su se $u$ početku fokusirali na eksplicitna verbalna i neverbalna ponašanja, odnosno ona koja je moguće opažati, poput komunikacije, napuštanja prostorije ili bacanja tanjura u zid. Međutim, razvojem ovog područja, ubrzo su uvidjeli da obraćanje pozornosti samo na opažljiva ponašanja nije dostatno, te da su za razumijevanje partnerskih interakcija važne i kognitivne i emocionalne reakcije na partnerovo ponašanje (Jacobson, McDonald, Follette i Berley, 1985; Baucom i Epstein, 1989). Naime, uočeno je da implikacije opažljivog ponašanja za vezu ovise o tome kako partner protumači određeno vidljivo ponašanje. Primjerice, osoba može zaključiti da partner nije iznio smeće zato što mu nije stalo do zajedničkog kućanstva ili zato što ne voli partnera. No, osoba može zaključiti da partner nije iznio smeće zato što je imao naporan dan na poslu i vrlo je umoran. Ova dva vrlo različita zaključka o okolnostima opažljivog ponašanja partnera dovest će do sasvim različitih partnerovih reakcija na ponašanje. Stoga su kasnije verzije Teorije socijalnog učenja uzele u obzir da se partnerski odnos može naći u problemima ne samo kada partneri razmjenjuju negativna ponašanja, nego i onda kada počnu partnerovo ponašanje percipirati i interpretirati kao negativno. U ovom aspektu Teorija socijalnog učenja počinje zalaziti u Atribucijsku teoriju (Weiner, 1983), točnije u atribuiranje partnerovog negativnog ponašanja, o čemu će riječi biti u poglavlju 1.5.

Iz istraživanja utemeljenih na Teoriji socijalnog učenja proizašlo je nekoliko važnih nalaza. Promatrajući interakcije partnera prilikom diskusije o problemima u vezi, odnosno prilikom određene vrste sukoba, uočeno je da zadovoljni parovi tijekom takve interakcije 
pokazuju više pozitivnih i manje negativnih ponašanja prema partneru u odnosu na partnere nezadovoljne vezom (Margolin i Wamplod, 1981). Osim što su i sami bili skloniji pokazivati negativna ponašanja, partneri nezadovoljni vezom su i na partnerovo ponašanje reagirali dodatnim negativnim ponašanjem. Ova bihevioralna sekvenca naziva se negativnom recipročnošću (Bradbury i Karney, 2014). Suprotno tome, zadovoljni parovi su bili u stanju zanemariti poneko partnerovo negativno ponašanje, poput neugodnog komentara, te i u takvim situacijama odgovoriti pozitivnim ponašanjem. Kao što ističu Smith, Vivian i O'Leary (1990), iako je partneri najčešće nisu svjesni, negativna recipročnost predstavlja važan prediktor nezadovoljstva vezom.

Teorija socijalnog učenja pružila je snažan teorijski okvir za proučavanje bliskih odnosa i omogućila razvijanje konkretnih alata za poboljšanje partnerskih odnosa. Bradbury i Karney (2014) ističu nekoliko ključnih doprinosa ove teorije. Prvo, naglašavajući važnost interakcije u odnosu, usmjerila je fokus istraživanja na partnersku dijadu i njihovu uzajamnost. Drugo, pruža objašnjenje kako dolazi do promjena u odnosu, čime daje dinamičan pogled na odnos, dok druge teorije zanemaruju aspekt promjene, pružajući statičan pogled. Iako i druge teorije i pristupi svakako uzimaju u obzir da se osjećaji partnera s vremenom mogu promijeniti, jedino Teorija socijalnog učenja objašnjava mehanizme putem kojih do te promjene dolazi. No, ova teorija ima i neke značajne nedostatke. Njome nije moguće objasniti neke vrlo česte obrasce razvoja veze, poput tzv. „uspona i padova“ u vezi. Prema Teoriji socijalnog učenja, zadovoljni parovi bi se trebali ponašati na način koji dodatno povećava zadovoljstvo vezom, a nezadovoljni parovi na načine koji dovode do dodatnog smanjenja zadovoljstva vezom. Drugim riječima, promjene su jednosmjerne. No, istraživanja ukazuju na čestu pojavu drugačijih obrazaca. U mnogim vezama partneri se nađu u lošim razdobljima kada prevlada nezadovoljstvo, no njihov odnos se naknadno popravi. Neki parovi nikada ne prekinu, iako imaju vrlo turbulentan, pa i nasilan odnos. Teoretičari smatraju da objašnjenja ovakvih obrazaca vjerojatnije leže u interakciji individualnih karakteristika partnera, te nekim okolinskim faktorima, koje Teorija socijalnog učenja ne uzima u obzir (Bradbury i Karney, 2014). Nadalje, iako je jedna od glavnih prednosti, snažan fokus na interakcije para predstavlja i glavni nedostatak Teorije socijalnog učenja, jer odgovara na pitanje kako se partneri ponašaju no ne i zašto se tako ponašaju, primjerice zašto su neki parovi mnogo uspješniji od drugih. Problemi u komunikaciji su posljedica mnogo šireg seta karakteristika svakog od pojedinaca koji čine par, no Teorija socijalnog učenja ne pruža smjernice što bi te karakteristike mogle biti. Kako navode Johnson i Bradbury (2015), iako se ne može zanemariti važnost interakcija u razumijevanju bliskih odnosa, cilj budućih istraživanja treba biti uklopiti Teoriju socijalnog učenja u dinamičniji okvir 
konceptualizacije promjenjive prirode bliskih odnosa koja uzima u odnos varijabilitet unutar para i između parova u obrascima razvoja veze, kao i individualne karakteristike partnera. Imajući spomenutu preporuku na umu, ovim istraživanjem se proširuju saznanja utemeljena na Teoriji socijalnog učenja uključivanjem elemenata proizašlih iz pojedinca koji utječu na ponašajne interakcije u vezi. Drugim riječima, zanima nas kako ono što partner donosi u vezu oblikuje njegovo ponašanje u konfliktnim situacijama u vezi.

\section{2. Komunikacija u vezi}

Kvalitetna komunikacija u vezi jedan je od ključnih faktora koji vezu čine uspješnom, budući da su partneri u međuzavisnom odnosu, te su želje, ciljevi i zadovoljstvo jednog partnera povezani sa željama, ciljevima i zadovoljstvom drugog partnera. Kada veza dobro funkcionira, komunikacija je prilično jednostavna, no neizbježno je da će se javiti situacije u kojima će želje ili ciljevi partnera biti međusobno suprotstavljeni (Fletcher i sur., 2013). Tada se javlja sukob, koji Kurt Levine (1948, prema Bradbury i Karney, 2013) definira kao situacije u kojima jedna osoba pokušava ostvariti svoje želje i ciljeve, a pri tome ometa želje i ciljeve druge osobe. Na sukobe mogu utjecati i drugi faktori koji situaciju sukoba čine još kompliciranijom. Osobe ne moraju uvijek biti svjesne jačine svojih emocija vezanih uz određenu temu, često ne znaju izraziti svoja očekivanja, a promjenjivost ciljeva i očekivanja može dovesti do potrebe za novim i teškim pregovaranjima u vezi (Bradbury i Karney, 2014). Parovi se susreću s raznolikim problemima oko kojih se javljaju sukobi u vezi, a među najčešćima su količina i kvaliteta zajednički provedenog vremena, financije, podjela kućanskih poslova, ljubomora, te sukobi vezani uz spolni život ali i nešto rjeđe ali vrlo ozbiljne teme poput zlouporabe opojnih sredstava (Storaasli i Markman, 1990). Bliske veze koje nemaju sukoba su vrlo rijetke i iznimne, a većina parova ima između 1 i 3 sukoba tjedno, uključujući 1 do 2 iznimno neugodna sukoba mjesečno (Guerrero, Andersen i Afifi, 2001). Očekivano, parovi koji češće imaju probleme u vezi i sukobe manje su zadovoljni vezom te češće prekidaju vezu (Kluwer i Johnson, 2007). Češći sukobi u vezi povezani su i s nepovoljnim ishodima na osobnoj razini, poput depresije (Beach i sur., 1998) i slabijeg zdravstvenog stanja (Kiecolt- Glaser i Newton, 2001). Iako su sukobi u vezi neizbježni, ono što je presudno je kako se ti sukobi rješavaju. Stoga možemo reći da je komunikacija prilikom sukoba u vezi najbolji indikator općenite komunikacije u vezi. Poteškoće u komunikaciji, posebno u situacijama sukoba, parovi navode kao najčešći problem u vezi (Storaasli i Markman, 1990). S time se slažu i terapeuti koji su uočili da su problemi u komunikaciji najčešći prigovor s kojim parovi dolaze na terapiju, ali i jedan od najštetnijih i 
najteže promjenjivih elemenata veze (Geiss i O'Leary, 1981). Međutim, pokazalo se da nije jednostavno odrediti što su ispravna i neispravna ponašanja partnera tijekom sukoba. Naime, iako prema Teoriji socijalnog učenja zadovoljstvo vezom pada kada u situaciji sukoba dolazi do kritiziranja i optuživanja, dok konstruktivna komunikacija i izražavanje empatije vode povećanju zadovoljstva vezom (Jacobson i Margolin, 1979; Jacobson, Waldron i Moore, 1980; Smith, Vivian i O’Leary, 1990; Stuart, 1980 prema Gill, Christensen i Fincham, 1999), razvila su se dva oprečna teorijska objašnjenja najboljeg načina komunikacije kada u vezi postoji problem. Prema prvom, tzv. modelu iskrene komunikacije, parovi bi trebali otvoreno izražavati svoje negativne osjećaje i misli, pristupiti rješavanju sukoba izravno i ne ostavljati probleme neriješenima (Fletcher i sur., 2013). Prema ovom shvaćanju, neriješeni problemi bujaju i narušavaju kvalitetu veze. S druge strane, prema modelu dobrog menadžmenta, redovno i otvoreno izražavanje negativnih misli i osjećaja „nagriza“ vezu, te bi sukobima trebalo pristupiti koristeći kompromis, suzdržavanje i prilagodbu. Umjesto opetovanih pokušaja rješavanja nekog problema, parovi bi trebali shvatiti da su neki problemi nerješivi te potisnuti razmišljanje o takvim problemima. Rezultati istraživanja djelomično potvrđuju oba pristupa, o čemu će biti više riječi u nastavku.

U početku istraživanja bliskih odnosa, smatralo se da su sukobi u vezama posljedica obiteljske povijesti pojedinca ili karakternih mana, te da nisu nikako posljedica nečega što se dogodilo među partnerima (Eisenstein, 1956, prema Bradbury i Karney, 2013). Naglim porastom stope razvoda brakova u SAD-u 1980-ih počinje se razvijati gledište da su interakcije među partnerima ključne, te razvijati snažno teorijski utemeljene terapijske intervencije za poboljšanje bračne dinamike. Slijedeći postavke Teorije socijalnog učenja, odnosno ideju da su zadovoljstvo vezom i stabilnost veze prvenstveno pod utjecajem toga kako partneri reagiraju u situacijama sukoba, 1970-ih su znanstvenici počeli opažati komunikaciju bračnih partnera u situacijama sukoba u laboratorijskim uvjetima (Gottman, 1979, Weiss i Heyman, 1997, prema Fletcher i sur. 2013). Željeli su utvrditi kako se komunikacija prilikom sukoba zadovoljnih i nezadovoljnih parova razlikuje, te predvidjeti koji će se parovi u budućnosti razvesti. Osnovna pretpostavka Teorije socijalnog učenja od koje su polazili bila je da partneri u vezama u kojima postoje problemi jednostavno nisu naučili vještine potrebne za uspjeh veze i rješavanje sukoba (Weiss, 1978). Da bi ova pretpostavka bila održiva, nužno je bilo da se načini ponašanja u vezi razlikuju između zadovoljnih i nezadovoljnih parova, što je istraživanjima i potvrđeno. Uočili su da u odnosu na parove koji su zadovoljni svojom vezom, nezadovoljni parovi češce kritiziraju partnera, prekidaju partnera dok govori i obezvrjeđuju partnerovo mišljenje, te se emocionalno ili fizički povlače. Rjeđe predlažu pozitivna rješenja problema, manje su pažljivi 
i izražavaju manje naklonosti prema partneru, te je manja vjerojatnost da će iskazivati pozitivni afekt poput humora (Gottman, 1998). Prema Gottmanovom strukturalnom modelu bračnih interakcija (1998), interakcije nesretnih parova karakterizira (1) manje pozitivnih ponašanja, a više negativnih, (2) veća prediktabilnost ponašanja među partnerima, te (3) duži ciklusi recipročnih negativnih ponašanja. Da u nesretnim vezama ima manje pozitivnih, a više negativnih ponašanja nego u sretnim vezama ne treba iznenađivati. No, važnim se pokazalo kako parovi komuniciraju u svojim svađama, pri čemu je uočeno da nezadovoljni parovi imaju 10 puta veću vjerojatnost koristiti neugodan ton glasa (povišen ton glasa, vikanje, agresivan način govora i sl.). Sadržaj poruke i način kako izgovaramo poruku su dva odvojena kanala komunikacije, a Bradbury i Karney (2013) drže da je za interpersonalne odnose često važnije kako nešto kažemo nego što kažemo. Veća prediktibilnost ponašanja među partnerima nam govori da nezadovoljni parovi, u odnosu na zadovoljne, pokazuju predvidljivije obrasce i strukture razgovora. Kako se nezadovoljan partner ponaša ograničeno je ili upravljano onime što je već ranije rečeno, te se stoga kod nezadovoljnih parova često ponavljaju iste svađe. Riječ je o „zaglavljenosti“ u komunikaciji o kojoj nezadovoljni parovi često izvještavaju, odnosno u tome da bez obzira kako rasprava ili sukob krenu, odvijaju se uvijek na isti način i završe uvijek na istome. U odnosu na zadovoljne parove, nezadovoljni pokazuju dulje cikluse uzajamnih negativnih ponašanja, što se prvenstveno odvija odgovaranjem destruktivnim komunikacijskim strategijama na destruktivne strategije partnera. Provođenjem longitudinalnih istraživanja testirano je predviđaju li negativni komunikacijski obrasci pad u zadovoljstvu vezom kroz vrijeme te razvod. Karney i Bradbury (1995) su meta-analizom 115 longitudinalnih studija utvrdili da su negativne ponašajne interakcije, poput hostilnosti, omalovažavanja ili povlačenja, povezane s većom vjerojatnošću razvoda ili prekida veze i smanjenjem zadovoljstva vezom kod oba partnera u funkciji vremena. Istovremeno, pozitivne ponašajne interakcije, poput konstruktivnog rješavanja problema, izražavanja naklonosti i humora, predviđaju više zadovoljstvo odnosom i veću vjerojatnost da će partneri ostati zajedno. Ovi nalazi potvrđuju pretpostavke Teorije socijalnog učenja. Negativna komunikacija narušava rješavanje problema tako što pobuđuje destruktivne emocionalne i ponašajne reakcije kod partnera, koje se prenose na buduće interakcije i narušavaju kvalitetu veze. Pozitivna ponašanja tijekom sukoba imaju suprotan učinak jer potiču osjećaj empatije, zajedništva i pružaju nagrađujuće ozračje u vezi (Bradbury i Fincham, 1991, Jacobson i Margolin, 1979). Jedan od glavnih dijadnih obrazaca koji objašnjava poguban utjecaj negativne komunikacije, a proizlazi iz Teorije socijalnog učenja, je negativna recipročnost, koju karakterizira pojačani negativni bihevioralni odgovor jedne strane na početno negativno ponašanje druge strane. Takve spirale negativnosti rastu 
prilikom interakcija nezadovoljnih parova iz nekoliko razloga (Fincham i sur., 2013). Prvo, partneri nezadovoljni vezom su skloniji protumačiti partnerov komentar kao namjerno povrjeđujući, o čemu će više riječi biti u poglavlju 1.5. Drugo, čak i kada partner pokuša smireno odgovoriti na početni negativan komentar ili ponašanje partnera, povrijeđene osjećaje neće biti u stanju u potpunosti zatomiti, pa će se oni očitovati barem u neverbalnoj komunikaciji. Stoga će partner vjerojatno percipirati ljutiti ton ili držanje i ponovno odgovoriti neprijateljstvom. Treće, budući da partnere obuzmu ljutnja i povrijeđeni osjećaji, ne reagiraju na pokušaje druge strane da smiri sukob, primjerice ne prihvaćaju ispriku. Budući da partneri vrlo teško napuštaju opisanu spiralu negativnosti, nađu se u situaciji kontinuirane razmjene „milo za drago“ ponašanja, što onemogućava rješavanje problema. Nadalje, budući da prema Teoriji socijalnog učenja partneri iz svake interakcije uče o svojoj vezi i formiraju buduća očekivanja, negativna recipročnost dovodi i do očekivanja budućih negativnosti, što rezultira smanjenjem zadovoljstva vezom.

Iako su inicijalna istraživanja partnerskih sukoba bila temeljena na analizi onoga što je rečeno, te eventualno načina kako je rečeno, odnosno opažljivih ponašanja, ubrzo je uočeno da te varijacije ne objašnjavaju sasvim razlike između zadovoljnih i nezadovoljnih parova. Pokazalo se da se sukobi ne javljaju samo zbog oprečnih ciljeva dvaju partnera, kako je Lewin smatrao, već i zbog sasvim različite percepcije i iskustava vlastite veze koje partneri imaju (Bradbury i Karney, 2013). Dnevničke studije su pokazale da je veće slaganje ili povezanost između dnevnih događaja i zadovoljstva vezom kod nezadovoljnih parova nego što je kod zadovoljnih, bez obzira jesu li događaji bili pozitivni ili negativni (Margolin, 1981). Jedno od ponuđenih objašnjenja ovog nalaza jest hipoteza reaktivnosti, koja pretpostavlja da su nezadovoljni parovi osjetljiviji na događaje u vezi, jer su neprestano na oprezu. Pokušavaju pronaći značenje u svakom partnerovom postupku ili izjavi, bez obzira jesu li dobri ili loši, jer na taj način svaki puta iznova procjenjuju svoju vezu (Jacobson, Follette i McDonald, 1982). S druge strane, zadovoljni parovi su manje osjetljivi na svakodnevne događaje jer imaju više pouzdanja u vlastitu vezu, pa ne postoje tolika svakodnevna odstupanja u zadovoljstvu vezom kao posljedica onoga što je rečeno taj dan. Istovremeno je utvrđeno da je slaganje između izvještaja muževa i žena o dnevnim događajima u vezi vrlo nisko. Slagali su se u svega 50\% slučajeva ili manje u vezi specifičnih događaja za koje je jedan od partnera izjavio da su se dogodili (Christensen i Nies, 1980). Iako je ovaj obrazac bio prisutan u svim vezama, bio je izraženiji kod nezadovoljnih parova. Pristranosti koje su uočene kod nezadovoljnih parova obično su bacale negativno svjetlo na partnera, pogoršavajući odnos. Naime, iako i partneri zadovoljni vezom i oni nezadovoljni vezom upućuju partneru poruke za koje smatraju da su 
pozitivnog tona, te im je cilj da poruka bude pozitivna, partneri nezadovoljni vezom takvu poruku tumače negativno, pripisujući joj negativnu konotaciju (Gottman, 1979). Stoga je postalo jasno da su kognicije partnera ključne za razumijevanje partnerskih sukoba. Stoga su autori počeli razvijati teorijske modele obrazaca komunikacije prilikom sukoba koji su osim ponašajnih aspekata sukoba uključivali i kognitivnu komponentu prisutnu kod pojedinog partnera.

\subsection{Obrasci komunikacije prilikom sukoba}

Prema Gottmanu (1994), temeljem domena zdravlja, fiziologije, ponašanja, afekta, zadovoljstva vezom i rizika prekida možemo razlikovati dva tipa bračnih parova: regulirane $i$ neregulirane. Regulirani parovi su oni koji koriste više pozitivne komunikacije od negativne. Parove se klasificira $u$ jedan od ova dva tipa temeljem njihove vlastite percepcije ponašanja koja iskazuju jedan prema drugome, a zadovoljstvo vezom visoko korelira sa stupnjem reguliranosti parova. Što je par više reguliran, to su u pravilu patneri zadovoljniji vezom. Gottman (1994) smatra da brakovi, pa tako i veze, imaju takozvanu bračnu ekologiju, koju određuje omjer pozitivnih i negativnih interakcija između partnera. Negativna ponašanja variraju od napada na partnera do iskazivanja beznađa i tuge (Shapiro i Gottman, 2004). Jedno od glavnih negativnih ponašanja je prijezir, odnosno namjerno omalovažavanje ili vrijeđanje partnera, koje se može iskazivati verbalno i neverbalno (Shapiro i Gottman, 2004). Dominiranje, defenzivnost i isključivanje partnera su također ponašanja koja partneri mogu iskazivati prilikom negativne interakcije. Nasuprot tome, pozitivne interakcije uključuju mnogo više topline nego negativna ponašanja. Partneri koji iskazuju pozitivna ponašanja često pritom iskazuju interes za interakciju, tražeći pojašnjenja i pokazujući iskrenu zabrinutost (Shapiro i Gottman, 2004). Pozitivne interakcije obično uključuju naklonost, humor, iznenađenje i sreću. Uz to, jasan indikator pozitivne interakcije jest validacija, odnosno otvorenost i prihvaćanje partnerovih stavova, viđenja i osjećaja što prenosi poruku poštovanja, čak i ako se osoba ne slaže s onim što partner govori ili njegovim stavovima (Shapiro i Gottman, 2004). Validaciju prepoznajemo putem uspostavljanja i održavanja kontakta očima, te parafraziranja. Poruka koja se takvom komunikacijom šalje je, da unatoč neslaganjima, partneri poštuju osjećaje i mišljenja drugoga (Holman i Jarvis, 2003). Takve interakcije stvaraju sigurno ozračje u vezi koje povećava vjerojatnost uspješnog razrješenja sukoba. Gottman (1994) je utvrdio da je za stabilnost veze potrebno da postoji pet pozitivnih interakcija na svaku negativnu. Ako takva ravnoteža ne postoji, bračna ekologija se narušava i partneri počinju biti frustrirani i osjetljivi, 
te se počinju učestalo i pretjerano prepirati. To dovodi do pada zadovoljstva vezom i osjećaja blagostanja u vezi (Gottman, 1998; Jelić, Kamenov i Huić, 2014). Time započinje negativna kaskada koja povećava vjerojatnost budućih sukoba i daljnjeg pada zadovoljstva vezom. Regulirani parovi, odnosno oni koji iskazuju više pozitivnih od negativnih interakcija, iskazuju obično jedan od tri stila sukoba: eksplozivni, potvrđujući i izbjegavajući (Gottman, 1994). O ovim stilovima će više riječi biti u nastavku. Kod nereguliranih parova Gottman (1994) razlikuje hostilne i hostilno ravnodušne parove, a oba tipa su karakterizirana negativnim emocijama, međusobnim napadima te prisustvom tzv. četiri jahača apokalipse u interakcijama (kritiziranje, prijezir, defenzivnost i isključivanje partnera), što u konačnici dovodi do raspada veze.

Regulirani eksplozivni parovi imaju vrlo emocionalne veze s ekstremnim razinama i pozitivnog i negativnog afekta. No, omjer od pet pozitivnih na svaku negativnu interakciju je i dalje očuvan, čime je i zadovoljstvo vezom relativno visoko. Parovi takvu vezu opisuju kao strastvenu i uzbudljivu (Gottman, 1994). Oba partnera su aktivno uključena u svaki sukob, te se gotovo nikad ne povlače, nisu pasivni niti izbjegavaju konfrontaciju. Umjesto racionalne rasprave o problemu, eksplozivni parovi žučnom raspravom pokušavaju uvjeriti drugu stranu da promjeni mišljenje. Prema Gottmanu (1994), eksplozivni parovi imaju žestoke ispade kada su u sukobu, no preostali aspekti veze su topli i puni ljubavi. Drugim riječima, negativne emocije koje se pojavljuju prilikom sukoba su izbalansirane ekstremno pozitivnim emocijama koje prevladavaju ostatak vremena. Ono što je ključno kod ovakvih parova je da ne percipiraju zlu namjeru u negativnim postupcima partnera, a što je konstrukt koji dobro zahvaća Mjera atribucija u vezi (Fincham i Bradbury, 1992) o čemu će više riječi biti u poglavlju 1.5.

Drugi regulirani stil sukoba je potvrđujući (Gottman, 1994). Ovakvi parovi, čak i tijekom samog sukoba, se ponašaju na način koji drugom partneru pokazuje da se njegove emocije i stavovi uvažavaju, pri čemu ostaju prilično smireni. Prisutnost takvog uzajamnog poštovanja eliminira brojne poteškoće koje mogu tijekom vremena narušiti vezu (Gottman, 1994). Sukobi izgledaju tako da jedna strana sluša pritužbu druge, pritom iskazujući potporu i zabrinutost, nakon čega slijedi pokušaj uvjeravanja druge strane u ispravnost vlastitog mišljenja. Pokušaji uvjeravanja nikada nisu nasilni i pokazuju poštovanje prema drugoj strani, tako da pozitivne interakcije višestruku nadmašuju broj negativnih interakcija. Kao i eksplozivni stil, kod ovog tipa sukoba ne postoji dojam zle partnerove namjere, hostilnosti ili namjernog povrjeđivanja partnerovih osjećaja. Sukob često poboljšava vezu potvrđujućih parova jer se nakon sukoba bolje međusobno razumiju (Gottman, 1994). Kroz takvu interakciju 
partneri uče da se međusobno cijene i poštuju, te da iskazuju međusobno ljubav, što dovodi do porasta zadovoljstva vezom. Ovakvi parovi ujedno iskazuju najvišu razinu zadovoljstva vezom.

Treći regulirani stil sukoba prema Gottmanu (1994) je izbjegavajući. Riječ je o parovima koji minimiziraju sukob i slažu se da se ne slažu oko nekih tema. Stoga sukobi ostaju neriješeni. Partneri u izbjegavajućem tipu veze će otvoriti sukob i iznijeti svoju stranu, ali će potom minimizirati pokušaje uvjeravanja druge strane $u$ ispravnost svojeg stajališta. Time stječu dojam da potvrđuju međusobnu ljubav i zadovoljstvo vezom, te se slažu da pozitivni aspekti veze nadmašuju važnost tema oko kojih se ne slažu. Ovakav stil ne uključuje hostilnost, a optimalan omjer pozitivnih i negativnih interakcija ostaje očuvan.

Sva tri Gottmanova (1994) regulirana stila komunikacije prilikom sukoba su po svojoj prirodi konstruktivna u smislu omogućavanja partnerima da održe omjer pet pozitivnih interakcija na svaku negativnu. Međutim, ne dovode svi stilovi do razrješenja sukoba ili unaprjeđenja veze, pa se mnogi autori protive Gottmanovom stajalištu da su svi regulirani stilovi po svojoj prirodi konstruktivni. Ograničenja Gottmanovih istraživanja su prvenstveno ta što ne nudi uvid u prediktore stilova komunikacije, što je važno jer se usvajanjem boljih stilova komunikacije može poboljšati zadovoljstvo vezom.

Iako je većina ranije spomenutih nalaza dobivena metodom opažanja, korisnost upitnika za razumijevanje komunikacije prilikom sukoba je očigledna (Bodenmann, Keiser, Hahlweg i Fehm- Wolfsdorf, 1998). Samoizvještaji o percepciji sukoba od strane partnera jednako su važni, ako ne i važniji, od opažanja stručnjaka jer omogućuju uvid u subjektivne podatke i vlastitu definiciju kvalitete komunikacije partnera. Nadalje, upitničke mjere su korisne u terapiji s parovima, kad nije moguće provoditi opsežna opažanja interakcija parova zbog troškova i vremena koje takve metode iziskuju. Stoga je primjena upitnika često nužna kako bi se osmislila adekvatna intervencija ili tretman. Iako su Holman, Busby, Doxey, Loyer- Carlson i Klein (1997) razvili Upitnik za evaluaciju veze (eng. RELATE-Relationship Evaluation Questionnaire), on ne uključuje samo mjeru komunikacije, već i zadovoljstvo vezom te stabilnost veze. Jedna od osnovnih kritika ovog instrumenta jest da ne razlikuje adekvatno prediktor i kriterij (stil sukoba) već ih kombinira u jednu mjeru, što predstavlja problem ukoliko je fokus istraživanja upravo na komunikaciji prilikom sukoba. Razvijeni su i drugi instrumenti za mjerenje komunikacije prilikom sukoba, primjerice Inventar bračne komunikacije (eng. Marital Communication Inventory (MCI), Bienvenu, 1971) te Inventar primarne komunikacije (eng. Primary Communication Inventory (PCI), Navran, 1967). No, ovi instrumenti nisu zahvaćali interaktivnu dimenziju komunikacije prilikom sukoba, te nisu razlikovali faze sukoba. Također, kao i mnogi drugi, pokazivali su problematične razine valjanosti i pouzdanosti 
(Heavey, Larson, Zumtobel i Christensen, 1996). Stoga je konstruiran Upitnik obrazaca komunikacije (eng. Communication patterns questionnaire, $C P Q$, Heavey, Larson, Zumtobel i Christensen, 1996), koji je do danas jedan od najčešće korištenih instrumenata u području bliskih odnosa. Njime se procjenjuje komunikacijsko ponašanje u vezi tijekom tri faze sukoba: kada se pojavi problem, tijekom rasprave o problemu i nakon završetka rasprave. Upitnik razlikuje nekoliko stilova komunikacije prilikom sukoba: konstruktivnu komunikaciju, uzajamno izbjegavanje i suzdržavanje, te zahtijevanje promjene i povlačenje, pri čemu razlikujemo žensko zahtijevanje uz muško povlačenje, te muško zahtijevanje uz žensko povlačenje.

Konstruktivno rješavanje sukoba karakteriziraju otvorena rasprava o konfliktnim temama, slobodno i pozitivno izražavanje emocija te zajednički trud oko postizanja rješenja u sukobu, a pozitivno je povezano sa zadovoljstvom brakom (Bodenmann, Kaiser, Hahlweg i Fehm-Wolfsdorf, 1998; Heavey, Larson, Zumtobel i Christensen, 1996). Upravo će konstruktivno rješavanje problema biti primarni interes ovog istraživanja. Konstruktivna komunikacija prema CPQ je ono što Gottman (1994) naziva potvrđujućim reguliranim stilom sukoba. Pruža partnerima osjećaj sigurnosti u vlastitu vezu i poštovanja od strane partnera, čime jača vezu i povećava vjerojatnost budućih pozitivnih interakcija. U visoko emotivnim situacijama kao što je sukob u vezi sudionicima može biti otežana introspekcija, što kasnije dovodi do iskrivljenja sjećanja na vlastite ili partnerove postupke. Riječ je o tipičnom nedostatku instrumenata koji se oslanjaju na samoizvještaje sudionika, ali problem je u ovoj situaciji dodatno potenciram predmetom mjerenja. Prednost subskale konstruktivne komunikacije Upitnika komunikacijskih obrazaca jest upravo vrlo visoka korelacija samoprocjena na upitniku i opažanja nezavisnih procjenjivača u situacijama sukoba, što ukazuje na visoku valjanost i pouzdanost ovog instrumenta (Heavey, Christensen, Larson i Zumtobel, 1996). Uzajamno izbjegavanje $i$ suzdržavanje svojstveno je partnerima koji ignoriraju postojanje problema i njegovo rješavanje, odnosno ni na koji način ne ulaze u sukob, no niti ne rade na rješavanju postojećeg problema. Zadovoljstvo vezom kod ovakvih je parova sniženo u odnosu na one koji probleme rješavaju konstruktivno, no i dalje nije pretjerano nisko. Gottman (1993), koji ovaj stil naziva reguliranim izbjegavajućim, zaključuje da je u takvim vezama prisutno manje negativnih ponašanja (npr. gađenja, prezira, kritike, okrivljavanja), no i manje pozitivnih ponašanja od onih koji ulaze u sukobe, što objašnjava stabilnost tih parova. Kako neriješeni problemi ipak postoje, zadovoljstvo je sniženo u odnosu na parove koji komuniciraju konstruktivno. Za razliku od Gottmana (1994) koji ovaj stil komunikacije smatra konstruktivnim, Christensen i Shenk (1991) ga drže nekonstruktivnim jer ne dovodi do 
razrješenja sukoba ili unaprjeđenja veze. Treći stil komunikacije je zahtijevanje promjene $i$ povlačenje. Sustavno je utvrđen izrazito negativan efekt ovakvog obrasca na kvalitetu i zadovoljstvo vezom, te visoka povezanost s razvodom (Christensen i Shenk, 1991; Gottman i Levenson, 2000). Ovaj obrazac izgleda tako da jedna osoba pokušava drugu uključiti u raspravu o problemu tako da ju kritizira, žali se i predlaže promjenu, dok njen partner pokušava izbjeći ili okončati taj razgovor promjenom teme, šutnjom ili odlaskom iz nastale situacije (Christensen i Shenk, 1991). Zahtijevanje i kritiziranje od strane partnera često izaziva povlačenje „,napadnute“ strane, što kod strane koja prigovara izaziva još intenzivnije zahtijevanje uključivanja u raspravu. Time se parovi često vrte u začaranom krugu negativne komunikacije. Posljedica je izraženo nezadovoljstvo vezom. Pokazalo se da obično žena zahtijeva, a muškarac se povlači (Christensen i Heavey, 1990; Christensen i Shenk, 1991; Eldridge i sur., 2007; Heavey, Layne i Christensen, 1993; Heavey i sur., 1996), a na podjelu uloga u sukobu utjecaja ima i tema rasprave.

Kurdek (1995) nudi dva moguća objašnjenja uzročno- posljedične veze stila komunikacije prilikom sukoba i zadovoljstva vezom, a čije postojanje je ranije utvrđeno longitudinalnim istraživanjima. Prva pretpostavka temeljena je na teoriji međuzavisnosti (Rusbult, 1983 prema Bradbury i Karney, 2010), koja postulira da omjer percipiranih nagrada i gubitaka u vezi određuje stupanj zadovoljstva vezom. Ukoliko pozitivne obrasce komunikacije razmatramo kao nagrade, a negativne obrasce komunikacije kao gubitke, učestala konstruktivna komunikacija dovodit će do povećanja zadovoljstva vezom, dok će ju destruktivni obrasci smanjivati. Drugo objašnjenje otvara mogućnost da stav jednog partnera (npr. razina zadovoljstva vezom) stvara psihološku klimu koja dovodi do izvođenja određenog ponašanja (npr. stil rješavanja sukoba), što za uzvrat ojačava i potvrđuju početni stav. Tu zapravo govorimo o samoispunjavajućem proročanstvu u vezi (Snyder, Tanke i Berscheid, 1977 prema Aronson, Wilson i Akert, 2005). Samoispunjavajuće proročanstvo u vezi je pojava do koje dolazi kada jedan partner ima očekivanje o tome kakav je drugi partner ili njihova veza (npr. „moj partner je dobra osoba, koja me voli“), to očekivanje utječe na ponašanje prema partneru (npr. ugodan ton glasa prilikom obraćanja partneru, davanje pohvale partneru), što izaziva da se partner ponaša u skladu s početnim očekivanjima (npr. budući da je primio pohvalu, partner se osmjehuje i grli partnera koji ga je pohvalio). Tako se čini da su se prvotna očekivanja pokazala istinitima, odnosno da se „proročanstvo“ ispunilo. U dosadašnjim istraživanjima je primarni fokus bio na obrascu zahtijevanja i povlačenja, upravo zbog njegovih pogubnih posljedica za vezu. Međutim, kako Gottman (1994) ističe, za uspješnost veze nije bitan samo izostanak loših obrazaca komunikacije odnosno negativnih interakcija, već i 
prisustvo pozitivnih. Kako su pokazale Krznarić, Kamenov i Huić (2015), učenje adekvatne komunikacije u vezi po modelu samo po sebi nije dovoljno. Naime, partneri koji su imali pozitivne modele $\mathrm{u}$ roditeljskom odnosu nisu usvojili nužno obrasce konstruktivne komunikacije, no partneri s lošim modelom u roditeljskom odnosu jesu usvojili destruktivne obrasce komunikacije od roditelja. Stoga ostaje nejasno što predviđa konstruktivnu komunikaciju prilikom sukoba, te koji su konstrukti ključni za modifikaciju stila komunikacije prilikom sukoba. U prijašnjim istraživanjima (Pranjić, 2012) faktori povezani s konstruktivnom komunikacijom prilikom sukoba bili su ekspresivnost i stavovi prema rodnim ulogama, te se pokazalo da ekspresivni i egalitarni parovi u situacijama sukoba češće komuniciraju konstruktivno. Međutim, i dalje velik dio varijance konstruktivne komunikacije ostaje neobjašnjen te se postavlja pitanje koji su elementi ključni za razumijevanje konstruktivne komunikacije prilikom sukoba. Odgovor bi mogla ponuditi Teorija planiranog ponašanja (Ajzen, 1980) koja naglašava da je svako voljno ponašanje, što komunikacija prilikom sukoba $\mathrm{u}$ vezi jest, posljedica stava o ponašanju, norme izvođenja takvog ponašanja te percipirane bihevioralne kontrole nad takvim ponašanjem.

\section{3. Teorija planiranog ponašanja}

Evaluiranje je temeljna i neposredna reakcija na svaki objekt koji za pojedinca ima određeni značaj (Jarvis i Petty, 1996, prema Ajzen i Cote, 2008), a rezultira time da nam se određene osobe, proizvodi ili aktivnosti sviđaju ili ne sviđaju, te smo im skloni ili neskloni. Drugim riječima, zauzimamo određeni stav prema predmetu evaluacije. Stav možemo definirati kao dispoziciju da na neki psihološki objekt odgovorimo s određenom razinom naklonosti li nenaklonosti (Eagly i Chaiken, 1993; Fisbein i Ajzen, 1975, prema Ajzen i Cote, 2008). Fazio (1990) stav definira kao naučenu asocijaciju u pamćenju između objekta i pozitivne ili negativne evaluacije tog objekta, pri čemu je snaga stava ekvivalentna snazi te asocijacije. Budući da je spomenuta evaluativna dispozicija hipotetski konstrukt koji nije moguće direktno mjeriti, o njoj možemo zaključivati samo putem opažljivih reakcija na objekt, poput izjava ponašajnih akcija i sl. Sadržaj stavova i vjerovanja nisu urođeni pojedincu, već se formiraju temeljem kulturoloških uvjerenja, društvenih normi i dostupnih informacija (Ajzen i Cote, 2008). Vjerovanja su temelj naših stavova, a nastaju pridruživanjem određenih atributa objektu (Fishbein, 1967, prema Ajzen i Cote, 2008). Ti atributi mogu biti drugi objekti, karakteristike ili događaji. Budući da su te atribucije već evaluirane kao pozitivne ili negativne, automatski i simultano stječemo stav prema objektu, te zbog toga nam se sviđaju objekti za koje vjerujemo 
da imaju poželjne karakteristike, a ne sviđaju nam se objekti čije karakteristike procjenjujemo negativnima. Iako ljudi mogu imati mnogo različitih vjerovanja o nekom objektu, vjeruje se da u određenom trenutku samo mali broj tih vjerovanja utječe na stav.

U ranim danima istraživanja stavova, većina istraživača se slagala da je ljudsko ponašanje upravljano socijalnim stavovima (Thomas i Znaniecki, 1918, Watson, 1925, prema Ajzen i Fishbein, 2005). Dapače, područje socijalne psihologije se u to vrijeme definiralo kao područje istraživanja stavova, jer se smatralo da su stavovi ključni za razumijevanje ljudskog ponašanja. No, unatoč brojnim istraživanjima koja su na prvi pogled potvrđivala ovu pretpostavku, neki istraživači su prigovarali pretpostavci da verbalne reakcije na simboličke podražaje (kao što su stavovi) pružaju uvid u to kako se ljudi ponašaju u stvarnome svijetu (Ajzen i Fishbein, 2005). Kako bi demonstrirao da ljudi kažu jedno, a čine drugo, LaPiere (1934, prema Firmin, 2010) je pratio mladi kineski par na njihovom putovanju u SAD-u i bilježio hoće li ih uslužiti u hotelima i restoranima. Kineski turisti su bili normalno usluženi u gotovo svakom objektu. Posjetili su 66 hotela i 184 restorana, te je svega 1 hotel odbio poslužiti turiste. No, potom je LaPiere (1934, prema Firmin, 2010) poslao pisane upite u posjećene objekte i pitao ih, kada bi ih posjetili kineski turisti, bili ih uslužili. Od 251 anketiranog ugostiteljskog objekta odgovorilo je njih 125. Među njima je $90 \%$ odgovorilo da nikada ne bi ugostili kineske turiste, a preostali su odgovorili da nisu sigurni. Očito je da je diskrepancija između stava i stvarnog ponašanja bila pozamašna. Corey (1937, prema Ajzen i Fishbein, 2005) je ispitao stavove studenata o varanju na ispitima na početku semestra, te je, omogućivši im nekoliko prilika za varanje tijekom semestra, pratio stvarno ponašanje. Nije utvrdio postojanje ikakve povezanosti između stava i ponašanja. Uslijedilo je povećano zanimanje istraživača za ovu temu, pokazalo se da su stavovi slab prediktor ponašanja, pa su mnogi počeli sumnjati u korisnost ispitivanja stavova (Festinger, 1964, prema Ajzen i Fishbein, 2005).

Ponuđeno je nekoliko mogućih objašnjenja nepostojanja povezanosti između stavova $i$ ponašanja. Dio istraživača smatrao je da problem leži u verbalnim mjerama stavova, koje omogućuju davanje socijalno poželjnih odgovora (npr. Campbell, 1950, Guilford, 1954, prema Ajzen i Fishbein, 2005). Stoga su odgovor bile indirektne mjere stavova, koje su mjerile fiziološke reakcije ili upitnici konstruirani tako da nije očito što ispituju. No, ovakve mjere su imale vrlo nisku pouzdanost, te se u nekim slučajevima pokazalo da neprikrivene mjere stavova imaju veću prediktivnu valjanost za ponašanje od prikrivenih mjera stavova (Kidder i Campbell, 1970, prema Ajzen i Fishbein, 2005). Drugo objašnjenje inkonzistencije stavova i ponašanja odnosilo se na multidimenzionalnost stavova. Mnogi teoretičari držali su da fokus na jednu evaluativnu dimenziju stavova ne odgovara kompleksnosti konstrukta (Allport, 1935, 
prema Ajzen i Fishbein, 2005). Već je u to vrijeme bilo jasno da se stavovi sastoje od emocionalne, kognitivne i ponašajne komponente, no dotadašnje mjere su ispitivale samo emocionalnu komponentu. Stoga je prigovor bio da se stavovi ne mogu adekvatno izmjeriti samo jednom komponentom, i to pogrešnom ukoliko želimo predviđati ponašanje, budući da je u tom slučaju potrebno ispitivati bihevioralnu ili kognitivnu komponentu (Katz i Stotland, 1959; Kothandapani, 1971; Ostrom, 1969; Triandis, 1964, sve prema Ajzen i Fishbein, 2005). Iako se činilo da će ovakav pristup polučiti bolje rezultate, mjere emocionalne, kognitivne i bihevioralne komponente su bile $\mathrm{u}$ visokim međusobnim interkorelacijama, te nezadovoljavajuće diskriminativne valjanosti (Widaman, 1985, prema Ajzen i Fishbein, 2005). Korelacije tako mjerenih stavova i ponašanju su i dalje bilo vrlo niske. No, rad Kothandapanija (1971) je pobudio nadu da je predviđanje ponašanja putem stavova ipak moguće. Kothandapani (1971) je ispitivao emocionalnu, kognitivnu i ponašajnu komponentu stavova o kontracepciji, te njihovu vezu s korištenjem kontracepcije. Dobivene su relativno visoke korelacije pojedinih komponenti stavova s ponašanjem (oko $r=.70$ ). Tada je uočena ključna razlika između Kothandapanijeva (1971) i prethodnih istraživanja. Naime, u prethodnim istraživanjima ispitivani su općeniti stavovi za predviđanje specifičnih ponašanja, dok je Kothandapani (1971) ispitivao stavove prema konkretnom ponašanju (stav prema korištenju kontracepcije) $\mathrm{i}$ isto to ponašanje (korištenje kontracepcije). Stoga je zaključeno da mora postojati više razina stavova.

Ajzen i Cote (2008) razlikuju dvije vrste stavova. Globalni stavovi su evaluativne dispozicije objekta prema kojem se ne može poduzeti neka konkretna radnja. To su, primjerice, stav prema Eiffelovom tornju, demokraciji ili nekom pjevaču. Druga skupina su stavovi prema ponašanju, koje definiramo kao evaluativne dispozicije prema specifičnom ponašanju kao objektu. Primjeri takvih objekata su doniranje novca u humanitarne svrhe, zapošljavanje osobe koja je pripadnik manjine, čitanje knjige o određenoj temi i sl. Iako bi bilo razumno očekivati da globalni stavovi predviđaju ponašanje, empirijski podaci opovrgavaju ovakve pretpostavke. Provedene meta-analize sustavno utvrđuju vrlo niske do niske korelacije između globalnih stavova i specifičnih ponašanja (Kraus, 1995, prema Ajzen i Cote, 2008). Poehlman, Uhlmann, Greenwald i Banaji (2009) su meta-analizom na 61 studiji utvrdili da je korelacija između globalnih stavova i eksplicitnog ponašanja svega .35, dok je korelacija između globalnih stavova i implicitnog ponašanja još niža, te iznosi svega .27. Ajzen i Cote (2008) navode kako takvi rezultati ne iznenađuju, jer da bi globalni stavovi predviđali ponašanje, ponašanje o kojem je riječ mora biti valjani indikator latentne dispozicije stava, odnosno mora odražavati globalni stav koji nas zanima. Međutim, ne možemo očekivati da je ijedno zasebno ponašanje dobar reprezentant široke domene stava. Autori tako primjerice navode da nevoljkost slikanja s 
Afroamerikancem (Linn, 1965, prema Ajzen i Cote, 2008) može biti odraz predrasuda prema Afroamerikancima, no može biti i posljedica niza faktora koji nemaju veze s predrasudama. Budući da je svako specifično ponašanje posljedica različitih faktora, Ajzen i Fishbein (1977) postuliraju bihevioralni kriterij u terminima četiri facete: akcija, meta na koju je akcija usmjerena, kontekst u kojem se akcija odvija, te vrijeme odvijanja akcije. $U$ istim terminima moguće je analizirati i bilo koju mjeru stava, a snažnu povezanost stava i ponašanja možemo očekivati samo ukoliko mjera stava i ponašanje dijele istu akciju, metu, kontekst i vrijeme. Opisani princip nazivamo principom kompatibilnosti (Ajzen, 1988, prema Ajzen i Cote, 2008). Globalni stav ipak je moguće zahvatiti posredno ukoliko raspolažemo nizom ponašanja koja uključuju različite akcije usmjerene prema meti, koje se odvijaju u različitim kontekstima i različitim trenucima $u$ vremenu. Agregacijom tih ponašanja, te stoga međusobnim poništavanjem elemenata koji nisu konstantni, ono što bi preostalo bilo bi općenit uzorak ponašanja prema određenom objektu stava. Stoga, možemo očekivati višu povezanost globalnog stava i općenitih uzoraka ponašanja, nego što je povezanost između globalnog stava i jednog određenog eksplicitnog ili implicitnog ponašanja prema objektu stava. Drugim riječima, ako osobu upitamo je li voljna fotografirati se s osobom muslimanske vjeroispovjesti (što je jedno eksplicitno ponašanje), iz njenog odgovora teško možemo zaključiti o njenom globalnom stavu o muslimanima, budući da na njenu spremnost na fotografiranje utječu i drugi faktori, poput sramežljivosti. Međutim, ako ispitamo niz ponašanja prema muslimanima, te potom ta ponašanja agregiramo u općenit uzorak ponašanja, dobivamo bolji dojam o globalnom stavu o muslimanima. Agregirana mjera raznih ponašanja prema muslimanima znatno više korelira s globalnim stavom prema muslimanima, nego što s globalnim stavom prema muslimanima korelira mjera jednog ponašanja vezanog uz muslimane (Ajzen i Cote, 2008). Empirijski podaci ovu pretpostavku i potvrđuju, izvještavajući o porastu korelacija između globalnog stava i općenitog uzorka ponašanja na .61 do .71 (Ajzen i Cote, 2008), u odnosu na povezanost između globalnog stava i mjere jednog određenog ponašanja, bilo implicitnog ili eksplicitnog, koja je obično oko 0.3. Navedeni podaci ističu važnost toga da mjera ponašanja i proučavani stav budu na istoj razini općenitosti i specifičnosti. Ukoliko su kompatibilni, korelacija između stava i ponašanja doseže vrijednost od .83 (Ajzen i Fishbein, 1977). Stoga, ukoliko želimo predvidjeti specifično ponašanje, moramo ispitivati stav prema tom specifičnom ponašanju.

Razvijajući tu ideju dalje, brojni teoretičari su predložili da je namjera izvođenja ponašanja, a ne stav o ponašanju, najbliži kognitivni antecedent izvođenja stvarnog ponašanja (Fishbein i Ajzen, 1975; Gollwitzer, 1993;). Empirijski nalazi su potvrdili ovu pretpostavku. 
Meta- analizama istraživanja u području različitih bihevioralnih domena utvrđena je prosječna korelacija između namjere i konkretnog ponašanja od .47 (Armitage i Conner, 2001; Notani, 1998, prema Ajzen i Fishbein, 2001), .53 (Shepherd, Hartwick, i Warshaw, 1988, prema Ajzen i Fishbein, 2001), .45 (Randall i Wolff, 1994, prema Ajzen i Fishbein, 2005), te .62 (van den Putte, 1993, prema Ajzen i Fishbein, 2005). Meta- analizom spomenutih meta- analiza, ali i drugih, utvrđena je općenita korelacija od .53 između namjere i ponašanja. Na visinu povezanosti između namjere i ponašanja utječe nekoliko faktora. Prvi je stabilnost namjere. Ukoliko se namjera promjeni od trenutka ispitivanja namjere do izvođenja ponašanja nije očekivano da će povezanost biti visoka. Vremenski interval između mjerenja namjere i procjene ponašanja se često uzima kao posredna mjera stabilnosti namjere, jer se pretpostavlja da protokom vremena sve više faktora može utjecati na promjenu namjere (Ajzen i Fishbein, 2005). Randall \& Wolff (1994, prema Ajzen i Fishbein, 2005) su istražujući vezu namjere i ponašanja na setu raznolikih ponašanja primijetili da je korelacija pala s .65 za intervale manje od jednog dana na .40 za intervale od jedne godine i više. Umjesto vremenskog intervala kao indikatora stabilnosti, u nekim istraživanjima je stabilnost namjere ispitivana direktno. Sheeran, Orbell i Trafimow (1999, prema Ajzen i Fishbein, 2005) su dva puta u razmaku od pet tjedana pitali studente namjeravaju li učiti preko praznika. Po završetku praznika, upitali su ih koliko su dana zaista i učili. Korelacija namjere i stvarnog ponašanja kod studenata koji su imali relativno stabilne namjere (nisu se promijenile unutar pet tjedana između ispitivanja) korelacija je bila .58, dok je korelacija namjere i stvarnog ponašanja kod studenata s nestabilnim namjerama bila svega .08 .

Brojni istraživači razlikuju izvođenje ponašanja, kao primjerice dizanje utega, i ostvarenja ciljeva, poput gubitka težine (Ajzen i Fishbein, 1980, Bandura, 1997). Ostvarenje cilja ne ovisi samo o ponašanju osobe, već i o drugim faktorima, stoga ljudi imaju veću kontrolu nad izvođenjem ponašanja nego nad ostvarenjem ciljeva. Čak i neka ponašanja, za koja bismo rekli da su pod voljnom kontrolom, ne ovise u potpunosti o pojedincu. Ajzen i Fishbein (2005) navode primjer darivanja krvi, gdje osoba može biti voljna dati krv, ali iz bilo kojeg medicinskog razloga nije prikladan donor, čime izvođenje ponašanja prestaje biti pod isključivom kontrolom osobe. No, većina ponašanja ipak jesu namjerna ponašanja pod kontrolom osobe. Neki primjeri niskih korelacija namjere i ponašanja dobivenih $u$ istraživanjima su posljedica ispitivanja ponašanja nad kojima osobe imaju nisku kontrolu. Predikcija ponašanja se poboljšava kada uz namjeru uključimo i stvarnu kontrolu nad ponašanjem. To je posebno slučaj kad se pojedinci razlikuju u stupnju stvarne kontrole koju imaju nad izvođenjem određenog ponašanja. No, stvarnu kontrolu za izvođenje ponašanja za 
većinu ponašanja nije moguće točno izmjeriti, što predstavlja metodološki problem. No, moguće je da percepcija kontrole koju pojedinac ima relativno točno odražava njegovu stvarnu kontrolu, zbog čega u mnogim slučajevima može predstavljati posrednu mjeru kontrole i poboljšati predikciju ponašanja (Ajzen i Fishbein, 2005). Mjere percipirane bihevioralne kontrole značajno doprinose postotku objašnjene varijance kriterijskog ponašanja u slučajevima kad je stvarna kontrola niža (Godin, Valois, Lepage i Desharnais, 1992, prema Ajzen i Fishbein, 2005). Konstruktivna komunikacija prilikom sukoba, koja predstavlja ciljno ponašanje u ovom radu, jest namjerno ponašanje jer osoba ima kontrolu nad time kako će se ponašati prilikom sukoba, no kako mjera konstruktivne komunikacije prilikom sukoba uključuje i postupke druge strane u sukobu, kontrola je donekle snižena, pa je korisno u predikciju uključiti mjere percipirane bihevioralne kontrole.

Iz navedenog je jasno da je namjera najbolji prediktor budućeg ponašanja, no postavlja se pitanje što dovodi do formiranja određene namjere. Upravo time bavi se Ajzenova Teorija planiranog ponašanja (Ajzen i Fishbein, 1980). Prema ovoj teoriji (Slika 2), ponašanje je pod utjecajem tri faktora: pozitivna ili negativna evaluacija ponašanja (stav prema ponašanju), percipirani socijalni pritisak da se ponašanje izvrši ili ne izvrši (subjektivna norma), te percipirana sposobnost izvođenja ponašanja (samoefikasnost ili percipirana bihevioralna kontrola). Bihevioralna vjerovanja i s njima povezane evaluacije proizvode općenito pozitivan ili negativan stav prema izvođenju predmetnog ponašanja. Točnije, ako percipirane prednosti premašuje percipirane nedostatke izvođenja ponašanja, osoba će vjerojatno formirati pozitivan stav prema ponašanju. Razmatranja vjerojatnog odobravanja ili neodobravanja ponašanja od strane prijatelja, obitelji, suradnika itd. nazivaju se normativnim vjerovanjima i vode ka percipiranom socijalnom pritisku, odnosno subjektivnoj normi, za izvođenje ili ne izvođenje određenog ponašanja. Kada ljudi misle da njima bitni pojedinci od njih očekuju da izvedu određeno ponašanje ili da se njima bitni pojedinci i sami ponašaju na određeni način, doći će do pritiska subjektivne norme da i sami izvedu ponašanje. No, kada su normativna vjerovanja protivna izvođenju ponašanja, zaustavit će izvođenje ponašanja koje okolina smatra nepoželjnim. Naposljetku, vjerovanja vezana uz prisustvo ili odsustvo faktora koji olakšavaju ili otežavaju izvođenje ponašanja nazivaju se kontrolnim vjerovanjima, te rezultiraju percepcijom da osoba može ili ne može izvesti određeno ponašanje. Ovi faktori se često nazivaju i samoefikasnošću (Bandura, 1977). Navedeni faktori rezultiraju bihevioralnom namjerom. Relativna važnost pojedinog od tri faktora varira ovisno o ponašanju i populaciji (Ajzen i Cote, 2008). Odnos bihevioralne namjere i ponašanja moderiran je stvarnom kontrolom djelovanja. Ukoliko je osoba dovoljno realna u procjenama svojih mogućnosti, 
percipirana sposobnost izvođenja ponašanja i stvarna sposobnost izvođenja ponašanja se izjednačavaju. Važno je napomenuti da bihevioralna, normativna i kontrolna vjerovanja nisu uvijek točan odraz stvarnosti, već mogu biti netočna, pristrana ili iracionalna (Ajzen i Fishbein, 2005). Spomenuta vjerovanja su i pod utjecajem širokog seta kulturoloških, osobnih i situacijskih faktora, pa se mogu razlikovati kod muškaraca i žena, mlađih i starijih, introvertiranih i ekstrovertiranih itd. Mogu biti i pod utjecajem fizičkog okruženja, socijalne okoline, izloženosti određenim informacijama, te širih dispozicija poput vrijednosti ili predrasuda (Ajzen i Fishbein, 2005). Međutim, kada je set vjerovanja formiran, pruža kognitivne temelje stavova, percipirane socijalne norme i percipirane bihevioralne kontrole, te naposljetku i namjere ponašanja. Stavovi, bihevioralna norma i bihevioralna kontrola, iako su konceptualno nezavisni koncepti, mogu korelirati jer se mogu dijelom ili u potpunosti temeljiti na istim informacijama (Ajzen i Fishbein, 2005). Primjerice, ako neko ponašanje rezultira pozitivnim zdravstvenim ishodom, osoba može razviti pozitivan stav prema ponašanju, te istovremeno zaključiti da bi bračni partner ili druga bitna osoba željela da izvodi to ponašanje. Nekoliko meta- analiza pokazalo je da se namjera ponašanja može predvidjeti sa znatnom točnošću iz mjera stavova prema ponašanju, subjektivne norme i percipirane bihevioralne kontrole (Albarrac'in i sur., 2001; Armitage i Conner, 2001; Godin i Kok, 1996; Hagger, Chatzisarantis i Biddle, 2002; Sheeran i Taylor, 1999; Shepherd, Hartwick i Warshaw, 1988; van den Putte, 1993, sve prema Ajzen i Fishbein, 2005). Za širok raspon ponašanja utvrđeno je da stavovi koreliraju s namjerom od .45 do .60 . Za predikciju namjera iz subjektivne norme, korelacije se kreću u rasponu od .34 do .42 , a za predikciju namjere iz percipirane bihevioralne kontrole od .35 do .46 (Ajzen i Fishbein, 2005). 


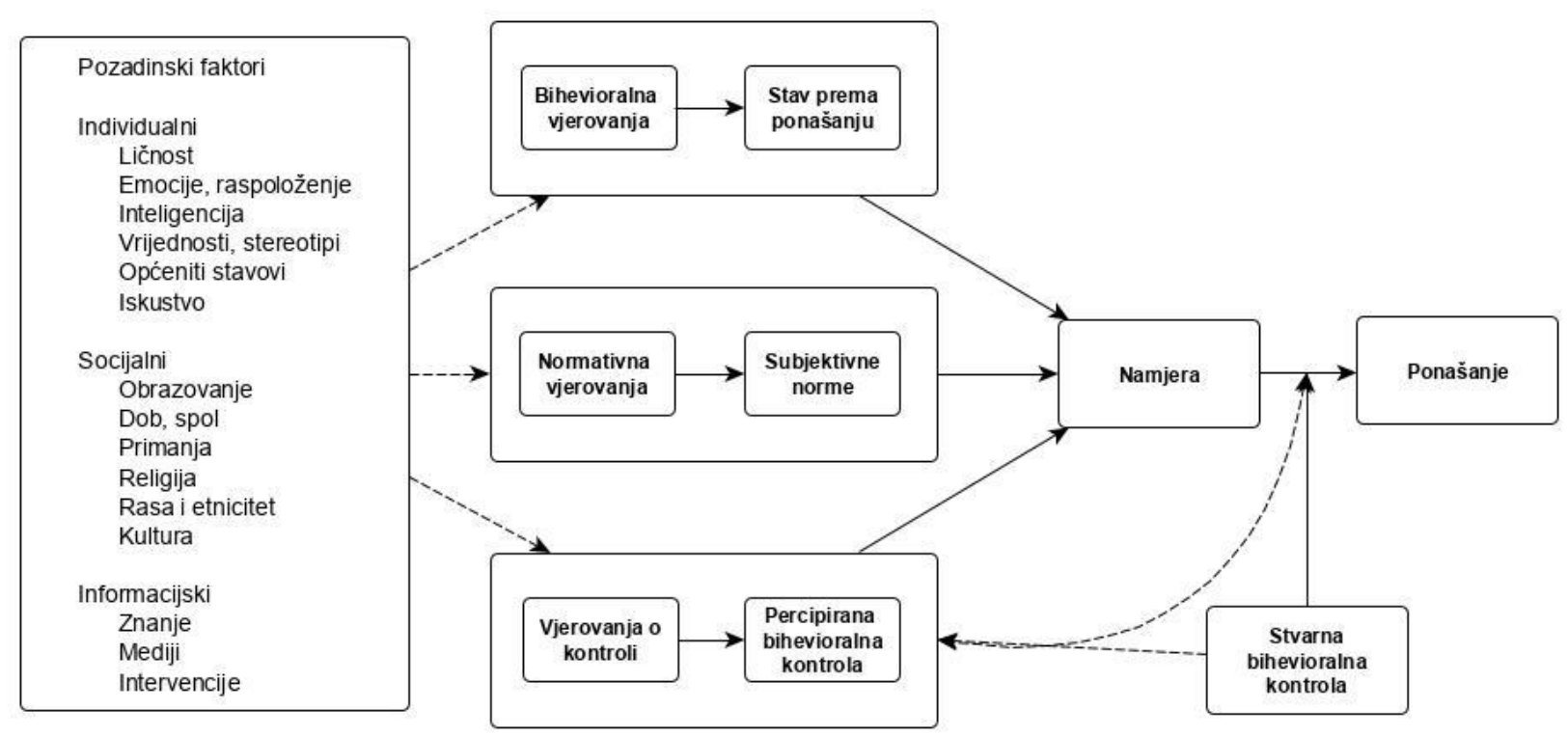

Slika 2. Shematski prikaz Teorije planiranog ponašanja (prilagođeno prema Ajzen i Fishbein, 2005)

Prema Teoriji planiranog ponašanja, pojedinci uzimaju u obzir vjerojatne posljedice ponašanja (bihevioralna vjerovanja), normativna očekivanja značajnih drugih (normativna vjerovanja), te faktore koji mogu pospješiti ili onemogućiti izvođenje ponašanja (percipirana bihevioralna kontrola) (Ajzen i Cote, 2008). U društvu postoji norma pozitivne komunikacije i konstruktivnog rješavanja sukoba. Također, većina ljudi izražava pozitivne stavove prema konstruktivnom rješavanju sukoba. Način na koji se ponašamo prilikom sukoba je pod kontrolom pojedinca, te on samostalno odabire kako će se ponašati u situaciji sukoba. Pozitivan stav prema konstruktivnom rješavanju sukoba, subjektivna norma prema takvom ponašanju te percipirana bihevioralna kontrola izvršavanja tog ponašanja tri su elementa koji bi prema Teoriji planiranog ponašanja (Ajzen i Fishbein, 1980) trebali dovesti do konstruktivnog ponašanja u situaciji sukoba. Međutim, očigledno je da se u mnogim intimnim vezama sukobi ne rješavaju na taj način, što za posljedicu ima visoke stope razvoda u Hrvatskoj i svijetu, prekide veza, a često neadekvatna komunikacija prilikom sukoba rezultira i nasiljem. Iako je nesumnjivo nužno uključiti spomenute elemente Teorije planiranog ponašanja u predviđanje konstruktivnog rješavanja sukoba, različite kognitivne i motivacijske odrednice mogu dodatno djelovati na objašnjenje kako će se pojedinac ponašati prilikom sukoba u intimnim odnosima. Te odrednice možemo smatrati pozadinskim faktorima Teorije planiranog ponašanja. Neke od 
odrednica koje mogu pomoći razumijevanju ove problematike i predviđanju ponašanja su vremenske perspektive i atribucijski stil, o kojima će više riječi biti u poglavljima 1.4. i 1.5.

Teorija planiranog ponašanja do sada je rijetko korištena u kontekstu bliskih odnosa, a prema dostupnim saznanjima u hrvatskom kontekstu nije uopće. Teorija planiranog ponašanja je općenito relativno slabo istraživana u Hrvatskoj, te je do sada objavljeno svega nekoliko radova koji su se bavili ovom teorijom. Prvenstveno je primjenjivana u području predviđanja potrošačkog ponašanja (npr. Tomić, 2016, Ilakovac, 2018), zdravstvenih ponašanja (npr. Kalebić Maglica, 2010, Brkljačić, 2003), te radnog ponašanja (npr. Punek, 2010, Tonković, 2013, Mijoč, 2013). Stoga je posebno zanimljivo primijeniti Teoriju planiranog ponašanja za predviđanje konstruktivne komunikacije prilikom sukoba kod hrvatskih parova.

\section{4. Vremenska perspektiva}

Sadržaj stavova i vjerovanja je formiran prema kulturološkim uvjerenjima, društvenim normama i dostupnim informacijama. Iako određeno vjerovanje može biti točna reprezentacija stvarnosti, često dolazi do pristranosti pod utjecajem raznih kognitivnih i motivacijskih procesa. Kao što navodi Allport (1954), takva vjerovanja mogu biti iracionalna, utemeljena na selektivnim ili pristranim informacijama ili na druge načine ne odgovarati realitetu. Upravo su ti kognitivni i motivacijski procesi koji mogu utjecati na formiranje specifičnih stavova dio koji prema Teoriji planiranog ponašanja nije dovoljno objašnjen. Budući da su prema ovoj teoriji u podlozi stavova prema ponašanju očekivanja pozitivnih ili negativnih ishoda izvođenja određenog ponašanja, koja dovode do evaluacije samog ponašanja kao pozitivnog ili negativnog, jasno je da postoji važna komponenta predviđanja ishoda budućih ponašanja. Odnos prema budućem ponašanju, te odabir budućih ciljnih ponašanja pod utjecajem su vremenske perspektive pojedinca, te je od posebne važnosti vremenska perspektiva budućnosti (Zimbardo i Boyd, 1999). Prema Keough, Zimbardo i Boyd (1999), doživljaj sebe, svijeta i međuljudskih odnosa se filtrira kroz kognitivne procese utemeljene na vremenu. Protok osobnog iskustva učimo spontano kategorizirati u prošlost, sadašnjost ili budućnost. Ovaj temeljni proces, nazvan vremenskom perspektivom, trajni je način odnosa prema ljudima i događajima, a naučen je u ranoj dobi putem kulture, obrazovanja i obiteljskih utjecaja (Nurmi, 1991). Vremenske kategorije prošlosti, sadašnjosti ili budućnosti koriste se pri kodiranju, pohranjivanju i dosjećanju događaja, te pri formiranju očekivanja i ciljeva (Boyd i Zimbardo, 2005). Idealni mentalni okvir, tzv. „uravnotežena vremenska perspektiva“‘, omogućuje osobi da fleksibilno odabire između kategorija prošlosti, sadašnjosti i budućnosti, ovisno o zahtjevima 
situacije, osobnim i društvenim preferencijama ili procjeni raspoloživih resursa. Uravnotežena vremenska perspektiva je vrlo rijetka (Zimbardo i Boyd, 2008). U stvarnosti se kod ljudi razvija tendencija da se prenaglašava jedna od vremenskih kategorija. Tada govorimo o vremenskoj orijentaciji na prošlost, sadašnjost ili budućnost. Kada se učestalo javlja, ova pristranost postaje prediktivna za ponašanje u brojnim svakodnevnim situacijama, te ju možemo smatrati varijablom individualnih razlika ili dispozicijskim stilom (Zimbardo i Boyd, 1999). No, to ne znači da je isključena mogućnost promjene orijentacije u određenim situacijama pod utjecajem okolinskih faktora (Crockett, Weinman, Hankins, Marteau, 2009). Vremenska orijentacija je u podlozi drugih psiholoških konstrukata kao što su postignuće, postavljanje ciljeva, preuzimanje rizika, traženje uzbuđenja, ruminacije, krivnja itd. (Zimbardo i Boyd, 1999).

Jedno od najranijih istraživanja vremenske perspektive proveo je Teahan (1957). U istraživanju u kojem je sudjelovalo 60 učenika sedmih i osmih razreda, sudionike je zatražio da napišu popis tema o kojima su razmišljali ili razgovarali u protekla dva tjedna, nakon čega ih je klasificirao u teme koje se tiču prošlosti, sadašnjosti ili budućnosti. Uočio je da oni učenici koji su naveli više tema usmjerenih na budućnost postižu bolje akademske rezultate, čime je među prvima utvrdio vezu između vremenske orijentacije i akademskog postignuća. Klineberg je 1968. proveo istraživanje na uzorku učenika kojim je pokazao da oni učenici koji su kontinuirano u stanju odgoditi neposredno zadovoljenje potreba ujedno i više usmjereni na budućnost. Na sličnom tragu bio je i Walter Mischel (Mischel, Shoda i Rodriguez, 1989) koji je tijekom 1960-ih i 1970-ih godina provodio tzv. Stanford marshmallow eksperimente u kojima je proučavao mogućnost odgode neposrednog zadovoljenja potreba kod djece predškolske dobi. Kasnijim longitudinalnim praćenjem sudionika dokazao je da ona djeca koja su u stanju odgoditi neposredno zadovoljenje, imajući na umu veće nagrade u budućnosti, postižu bolje ishode na raznim područjima života. Postižu viši akademski uspjeh, uspješniji su na poslu, imaju prikladniji indeks tjelesne mase te su zdraviji itd. Lamm, Schmidt i Trommsdorf (1976) istraživali su nade i strahove njemačkih adolescenata koji su pripadali srednjem ili nižem društvenom sloju. Zamolili su sudionike da navedu neke svoje strahove i ciljeve, te godinu kada vjeruju da bi se mogli ostvariti. Operacionalizacija vremenske perspektive budućnosti pritom je bila to koliko daleko o budućnosti su adolescenti razmišljali. Uspoređujući društvene slojeve, primijetili su da adolescenti srednje klase razmišljaju o daljoj budućnosti nego adolescenti nižeg sloja, čime su pokazali da je vremenska perspektiva povezana sa socio-demografskim varijablama. Uskoro se javila potreba za razvojem upitničkih mjera vremenske perspektive, u čemu je prednjačio Roos (1964) razvivši Inventar vremenskih referenci (eng. Time Reference Inventory). Upitnik je propitivao sudionike, primjerice, je li najsretnije razdoblje njihovog 
života bilo u prošlosti, u sadašnjosti ili im tek prethodi. Uz to, sudionici trebaju navesti koliko će godina imati kada se dogodi događaj iz pitanja. Ovisno o broju čestica razvrstanih u pojedinu temporalnu kategoriju, sudionik dobiva ukupni rezultat vremenske orijentacije na pojedinu dimenziju. Stewart je 1976. razvio Inventar ličnosti (eng. The Stewart Personality Inventory) koji je između ostalog sadržavao i mjere vremenske orijentacije na budućnost, no metrijske karakteristike ovog instrumenta nisu bile zadovoljavajuće, te često nije davao interpretabilne faktore. Prekretnica u istraživanjima vremenske perspektive dogodila se 1999. godine razvojem Zimbardovog inventara vremenskih perspektiva (eng. Zimbardo Time Perspective Inventory, ZTPI), koji je danas uvjerljivo najčešće korišten instrument za mjerenje odnosa prema vremenu te će biti primijenjen i u ovom istraživanju. Zimbardo i Boyd (1999) faktorskom analizom rezultata na ZTPI-ju su otkrili postojanje pet faktora vremenske perspektive: prošlost negativna, prošlost - pozitivna, sadašnjost - hedonistička, sadašnjost - fatalistička i budućnost.

Faktor prošlost - negativna ocrtava općenito pesimističan, negativan i odbojan stav prema prošlosti. Budući da je prošlost rekonstruktivne prirode, ovi negativni stavovi mogu biti posljedica stvarnih negativnih iskustava ili traumatičnih događaja, ali i negativne rekonstrukcije bezazlenih događaja (Zimbardo i Boyd, 1999). Riječ je o osobama nezadovoljavajućih međuljudskih odnosa, s manje prijatelja, koji rijetko doživljavaju zadovoljstvo u životu (Zimbardo i Boyd, 1999). Ovaj faktor vremenske perspektive mogao bi imati utjecaj na stav o ponašanju., očitujući se u negativnijem stavu prema konstruktivnoj komunikaciji.

Faktor prošlost - pozitivna odražava topao i sentimentalan osjećaj prema prošlosti (Boyd i Zimbardo, 2005). Riječ je o osobama koje se rado prisjećaju prošlosti i uživaju u obiteljskim ritualima. Žene postižu nešto više rezultate od muškaraca na ovoj dimenziji (Zimbardo i Boyd, 1999). Za razliku od faktora negativne prošlosti, ovaj faktor opisuje zdrav odnos prema životu. Zimbardo i Boyd (1999) opisuju osobe s dominantnim faktorom pozitivne prošlosti kao pomalo introvertirane, s bliskim prijateljstvima, te većom vjerojatnošću da su trenutno u stabilnoj romantičnoj vezi. Pretpostavljeno je da su osobe prošlosti pozitivne sklonije pozitivnijem stavu o konstruktivnoj komunikaciji.

Faktor sadašnjost - hedonistička reprezentira hedonistički, bezbrižan stav prema životu, te sklonost riziku. Riječ je o osobama usmjerenim na trenutne užitke, bez većih briga oko posljedica u budućnosti (Zimbardo i Boyd, 1999). Osobe s izraženim faktorom hedonističke sadašnjosti su impulzivne, obuzete sadašnjošću i željne stalnog uzbuđenja (Boyd i Zimbardo, 2005). Nisu spremne ništa žrtvovati u sadašnjosti za buduće nagrade. Karakterizira ih slaba samokontrola, te naglasak na traženju uzbuđenja i noviteta. Prema Zimbardo i Boyd (1999) to su pojedinci koji češće konzumiraju alkohol i druga opojna sredstva, nisu religiozni, imaju 
nejasne buduće ciljeve. Prepuni su energije, uključeni u mnogobrojne aktivnosti i sudjeluju u velikom broju raznovrsnih sportova. Osobe ove orijentacije mogle bi imati sniženu namjeru prilagođavanja socijalnim normama o prakticiranju konstruktivne komunikacije.

Faktor sadašnjost - fatalistička se u mnogočemu razlikuje od prethodnog faktora. Riječ je o faktoru koji predstavlja fatalistički, bespomoćan stav prema životu i budućnosti. Osobe s izraženim fatalističkim odnosom prema sadašnjosti vjeruju da imaju vrlo malo kontrole nad događajima u svom životu, da sreća igra veliku ulogu u svakidašnjim događajima, te se prepuštaju „sudbini““. Ovakvo viđenje života negativno korelira s razmišljanjem o budućim posljedicama vlastitih djela (Zimbardo i Boyd, 1999). Prema Zimbardo i Boyd (1999) riječ je o pojedincima koji su nezadovoljni svojim životom i ne vjeruju da je ikakvo poboljšanje moguće. Zbog osjećaja bespomoćnosti, ovi pojedinci imat će sniženu percipiranu bihevioralnu kontrolu vezanu uz izvođenje ponašanja konstruktivne komunikacije.

Faktor budućnost je zastupljen kod pojedinaca sklonih planiranju, kod kojih dominira usmjerenost na ciljeve i buduće nagrade (Zimbardo i Boyd, 1999). Žene postižu značajno više rezultate od muškaraca na ovoj dimenziji. Utvrđena je povezanost sa savjesnošću, preferencijom za konzistentnost, ovisnošću o nagradama, te sniženim traženjem uzbuđenja i noviteta (Zimbardo i Boyd, 2008). Istovremeno, faktor budućnosti negativno je povezan s ponašanjima koja mogu ugroziti buduće ciljeve, kao što su agresivnost, impulzivnost i preuzimanje rizika (Zimbardo i Boyd, 1999). Prema istraživanju Zimbarda i Boyda (1999), osobe s orijentacijom na budućnost su vrlo organizirane, ambiciozne i spremne žrtvovati trenutne užitke za postizanje svojih ciljeva u budućnosti. No, važno je napomenuti da postoje dvije vrste usmjerenosti na budućnost: usmjerenost na buduće ciljeve i strah od budućnosti. Prva vrsta usmjerenosti na budućnost karakteristika je uspješnih, cilju usmjerenih pojedinaca, dok je druga vrsta svojstvena anksioznim pojedincima. Pretjerano strahovanje o budućnosti sprječava osobu da uživa u sadašnjosti i bude zadovoljna svojim životom (Zimbardo i Boyd, 2008). Međutim, ZTPI ne razlikuje ove dvije vrste budućnosti. Pretpostavlja se da su osobe orijentirane na budućnosti sklone prilagođavanju socijalnim normama, posjeduju pozitivan stav o konstruktivnoj komunikaciji te percipiraju svoju bihevioralnu kontrolu visokom. U pojedinim istraživanjima faktorska analiza je ukazala na moguće postojanje šestog faktora koji ocrtava negativan stav prema budućnosti, no većina istraživanja i dalje dobiva petfaktorsko rješenje (Worrell i Mello, 2007). U novije vrijeme pojavilo se nekoliko skraćenih verzija ZTPI-ja (npr. Zhang i sur., 2013; Sircova i sur., 2014; Przepiorka i sur., 2016), no kako su čestice uklanjane temeljem statističkih pokazatelja, upotrebljivost ovakvih skraćenih verzija nije potvrđena $\mathrm{u}$ istraživanjima drugih istraživača. Worrell i sur. (2016) su pristupili smanjenju broja čestica s 
teorijskog stajališta umjesto statističkog, što je rezultiralo dobrom faktorskom strukturom, no razinama pouzdanosti ispod prihvatljivih. Zimbardov inventar vremenskih perspektiva dizajniran je usporedo s razvojem koncepta vremenskih perspektiva, te iako su razvijane i druge mjere za pojedine dimenzije, najčešće budućnost, npr. Consideration of Future Consequences Scale (Petrocelli, 2003), Future Time Orientation Scale (Gjesme, 1979), ZTPI ostaje jedini sveobuhvatni instrument koji pokriva svih pet vremenskih perspektiva.

\subsubsection{Vremenska perspektiva i bliski odnosi}

Bliski odnosi i vremenske perspektive su blisko povezani, budući da svaka bliska veza ima točku početka zajedničkog odnosa. Prije te točke ne postoji zajednička prošlost, te su obje strane prvenstveno usmjerene na sadašnjost (Zimbardo i Boyd, 2008). Kako se veza razvija, zajednička prošlost se povećava i pojedinci počinju formirati očekivanja vezana uz budućnost. Slijedom toga, razvijaju se novi stavovi prema vremenu. Ako svaka veza, bez obzira na trajanje, ima prošlost, sadašnjost i budućnost, očekivano je pretpostaviti da će način kako partneri doživljavaju vrijeme biti značajan faktor u zadovoljstvu vezom, predanosti, kvaliteti i dugovječnosti veze (Zimbardo i Boyd, 2008). Vremenska perspektiva je češće istraživana u području postignuća (akademskog, poslovnog, postavljanje ciljeva) nego u kontekstu bliskih odnosa, no nekoliko nalaza važnih za ovo istraživanje ipak postoji. Tako su primjerice Akirmak, Alhan, Femir, Ince i Tezcan (2012) utvrdili da osobe izražene prošlosti negativne i sadašnjosti fatalističke imaju iskrivljene percepcije sebe, ali i svojih bliskih odnosa, ponajprije ljubavnih veza, dok su oni usmjereni na prošlost pozitivnu i sadašnjost hedonističku pokazivali najtočnije percepcije. Takva iskrivljenja mogu dovesti do razlika u stavovima, normama i percipiranoj bihevioralnoj kontroli za niz ponašanja vezanih uz interpersonalni kontekst. U istraživanju partnerskih dijada, Stolarski, Wojtkowska i Kwiecińska (2015) su pokazali da vremenske perspektive predviđaju indikatore zadovoljstva vezom, pri čemu su utvrđeni efekti i aktera i partnera. Prošlost negativna bila je povezana sa sniženim općenitim zadovoljstvom vezom, dok se prošlost pozitivna pokazala štetnom za seksualno zadovoljstvo. Više općenito zadovoljstvo vezom bilo je povezano s uravnoteženom vremenskom perspektivom. Ono što je posebno zanimljivo, utvrđeno je da se prediktivnost pojedinih vremenskih perspektiva za indikatore zadovoljstva vezom mijenja s protokom vremena provedenog u vezi. Holman i Zimbardo (2009) su utvrdili da pojedinci orijentirani na budućnost primaju više socijalne podrške od obitelji i prijatelja te izvještavaju o više smislenih veza s osobama koje su im važne u životu. Suprotno tome, Öner (2000) pretpostavlja da su osobe usmjerene na budućnost manje 
zadovoljne svojim vezama jer su izbirljivije, opreznije i imaju viša očekivanja vezana uz budućnost svoje veze. Utvrdio je da su vezom najzadovoljniji oni usmjereni na sadašnjost. Taj nalaz je u suprotnosti s ranijim tvrdnjama Zimbarda i Boyda (1999) koji ističu da osobe usmjerene na sadašnjost imaju sniženu emocionalnu stabilnost te da je manje vjerojatno da će razvijati kvalitetne i smislene veze. Međutim, Önerov (2000) nalaz moguće je interpretirati u svjetlu toga da su pojedinci orijentirani na sadašnjost ulažu više truda u vezu u sadašnjem trenutku što rezultira većim zadovoljstvom vezom u bilo kojem trenutku. Međutim, ovim istraživanjem nije ispitana duljina veze sudionika, koja bi dala novo svjetlo na predanost vezi, budući da iz definicije pojedinih vremenskih perspektiva proizlazi da bi pojedinci orijentirani na budućnost trebali biti više predani vezi od onih usmjerenih na sadašnjost. Ako je predanost pojedinaca usmjerenih na sadašnjost zaista manja, to bi značilo da su njihove veze kraće, što je u skladu s ranijim istraživanjima (Stolarski i sur., 2016). Istovremeno, moguće je da pojedinci orijentirani na budućnost postepeno razvijaju vezu, koja je smislenija i ima potencijala da bude dugotrajnija, te će možda tijekom duljeg perioda vremena biti zadovoljniji vezom od onih usmjerenih na sadašnjost. Na spomenuta pitanja moguće je odgovoriti jedino longitudinalnim istraživanjima, koja zasad ne postoje. Öner (2001) je drugim istraživanjem utvrdio da je vjerojatnije da osobe koje izvještavaju o nezadovoljstvu svojom ljubavnom vezom postižu više rezultate na dimenziji budućnosti u odnosu na one koji su zadovoljni vezom. Iako se takav nalaz na prvu čini iznenađujućim, Öner (2001) nalaz argumentira time da su osobe usmjerene na budućnost možda spremnije ostati u vezi kojom nisu zadovoljni i pokušati ju popraviti, u nadi u bolju budućnost. Dodatno objašnjenje iznenađujućih nalaza vezanih uz orijentaciju na budućnost i zadovoljstva vezom jest priroda vremenske orijentacije na budućnost. Naime, osobe usmjerene na budućnost više razmišljaju o budućem statusu svoje veze, prvenstveno o budućem zadovoljstvu vezom te je slijedom toga manje vjerojatno da će u sadašnjosti izjavljivati da su sretni i zadovoljni u vezi, budući da očekuju više od veze u budućnosti. Kamenov i Huić (2012) te Krznarić, Kamenov i Huić (2013) na uzorku mladih odraslih osoba u Hrvatskoj utvrdile su da vremenske perspektive doprinose objašnjavanju aktivnog (osnaživanje veze i rješavanje problema) i pasivnog (izbjegavanje predanosti i preferencija za rutinu) ponašanja u vezi. Osnaživanju veze bile su najsklonije osobe izraženijih adaptivnih vremenskih perspektiva (prošlost pozitivna, sadašnjost hedonistička i budućnost), aktivnom rješavanju problema osobe orijentirane na prošlost i budućnost, što je u skladu s nalazom da su izbjegavanju predanosti najsklonije osobe usmjerene na sadašnjost, te osobe koje imaju negativno viđenje vlastite prošlosti, odnosno orijentirane na negativnu prošlost. Preferenciju za rutinu pokazale su osobe izražene prošlosti pozitivne i budućnosti. Krznarić, Huić i Kamenov 
(2013) su na sličnom uzorku utvrdile i da je kod osoba neadaptivnih vremenskih perspektiva (prošlost negativna i sadašnjost fatalistička) prisutno sniženo zadovoljstvo, stabilnost i kvaliteta veze, te da isti pojedinci ujedno poduzimaju manje koraka za unaprjeđenje veze, kao što su upoznavanje partnerovih prijatelja, roditelja, razmatranje zajedničkog života i slično.

Zimbardo i Boyd (2008) dotakli su se i pitanja sukoba u bliskim odnosima pod vidom vremenskih perspektiva. Ističući da su u pravilu žene više orijentirane na budućnost a muškarci na sadašnjost, pretpostavljaju da bi jedan od uzroka konflikata u heteroseksualnim vezama mogla biti i ta neusklađenost. Takva temporalna neravnoteža u vezi, kako ju nazivaju Zimbardo i Boyd (2008), može rezultirati time da žena počinje zahtijevati određene pomake i promjene u vezi, imajući u vidu zajedničku budućnost, dok je muškarac zadovoljan statusom quo i usmjeren na sadašnjost, te se pred ženinim zahtjevima počinje povlačiti, što može dovesti do sukoba. Očito je da govorimo zapravo o komunikacijskom obrascu ženskog zahtijevanja i muškog povlačenja. Kako se sukob pojačava, negativna viđenja i razmišljanja mogu se prenijeti na druga područja veze, postupno nagrizajući vezu. Prema Zimbardu i Boydu (2008), osvješćivanje međusobnih razlika u vremenskim perspektivama i uzimanjem tih razlika u obzir, moguće je postići kompromis kako bi se smanjili sukobi u sadašnjosti. S vremenom, takav pristup vodi razvoju zajedničke vremenske perspektive kao para, što rezultira uspješnijim vezama.

Rabinovich, Morton i Postmes (2010) su ukazali na važnost vremenske perspektive pri predviđanju ponašanja, dokazavši da je veza između stava o ponašanju i izvođenja ponašanja snažnija kod pojedinaca orijentiranih na budućnost. U istraživanju Krznarić, Kamenov i Huić (2015) vremenske perspektive nisu izravno predviđale stilove komunikacije prilikom sukoba, iako su vremenske perspektive povezane s mnogim ishodima u bliskim odnosima. Moguće je da vremenske perspektive, iako ne djeluju izravno, posredno predviđaju stilove komunikacije prilikom sukoba preko nekih drugih varijabli. Stoga je razumno pretpostaviti da će vremenske perspektive utjecati na sve tri antecedentne komponente Teorije planiranog ponašanja (stav prema ponašanju, subjektivna norma, percipirana bihevioralna kontrola). Iz toga će slijediti namjera ponašanja, koja predviđa stilove komunikacije prilikom sukoba. 


\section{5. Atribucijska teorija}

Kao što je ranije spomenuto, Atribucijska teorija je proizašla iz Teorije socijalnog učenja, te je njena svojevrsna nadogradnja. Atribucija je kauzalno objašnjenje za događaj ili ponašanje (Harvey i Martinko, 2010). Procesom atribuiranja uzroka ljudi pokušavaju objasniti svoja, ali i tuđa ponašanja. Atribucijski proces nešto je u što se ljudi upuštaju mnogo puta svakoga dana, a toliko je automatiziran da toga nismo niti svjesni (Harvey i Martinko, 2010). Međutim, mnoga istraživanja potvrđuju da je stvaranje kauzalnih atribucija presudno za mogućnost prilagodbe u promjenjivoj okolini i prevladavanje teškoća s kojima se svakodnevno susrećemo. Kada je ishod povoljan, atribucije nam pomažu da shvatimo što je dovelo do takvog ishoda kako bismo takva ponašanja mogli ponoviti (Kamenov, 1991, 1998). S druge strane, kada iskusimo negativan ishod, atribucije nam omogućuju prepoznavanje i izbjegavanje faktora koji su do takvog ishoda doveli.

Mnogi smjerovi ranih istraživanja atribucija proizašli su iz Kelleyevog $(1972,1973)$ modela kovarijacije i Weinerovog (1985) rada na atribucijama u kontekstu postignuća. Prema Kelleyju (1972), pojedinci određuju uzrok događaja uzimajući u obzir informacije o konzistenciji, konsenzusu i distinktivnosti predmetnog ponašanja ili događaja. Primjerice, ako neka osoba prekrši dano obećanje, zapitat ćemo se krši li ta osoba i inače obećanja koja nam daje (konzistencija - koliko je ponašanje konzistentno u sličnim situacijama), krše li i druge osobe obećanja koja su nam dala (konsenzus - ponašaju li se i druge osobe slično prema nama), te krši li osoba i obećanja koja je dala drugima (distinktivnost - je li isto ponašanje usmjereno i na druge). Koristeći te informacije, donosimo zaključak o internalnoj (npr. ponašao se tako jer je takav tip osobe) ili eksternalnoj (npr. ponašao se tako zbog situacije ili okolnosti u kojima se našao) atribuciji uzroka. Suprotno tome, Weiner (1985) se usmjerio na motivacijske i afektivne posljedice kauzalnih prosudbi koje ljudi donose za situacije povezane s uspjehom. U svojem ključnom radu o atribucijama u području postignuća, Weiner (1985) opisuje pet dimenzija kauzalnosti: lokus kauzalnosti, stabilnost, podložnost kontroli, namjeru i globalnost. Lokus kauzalnosti opisuje mjesto uzroka ponašanja kao internalnog (unutar osobe) ili eksternalnog (izvan osobe) osobi koja je ponašanje izvela. Stabilnost se odnosi na to je li uzrok stalan ili varira u funkciji vremena. Podložnost kontroli opisuje je li uzrok pod svjesnom kontrolom osobe. Namjera upućuje je li do ponašanja došlo zbog namjernih ili nenamjernih uzroka osobe. Globalnost opisuje je li uzrok specifičan u konkretnoj situaciji ili se može generalizirati na različite okolnosti (Graham, 1991; Weiner, 1979; Weiner 1985). Weinerova (1983) teorija atribucija uključuje i jasnu temporalnu dimenziju. Prva karakteristika povezana s vremenom 
tiče se očekivanja vezanih uz ishode, a utemeljena je na povijesnom slijedu prethodnih iskustava. Kada ljudi razmatraju svoje aktivnosti, donose zaključke o tome koja ponašanja dovode do uspjeha. To čine dijelom temeljem kauzalnih atribucija prijašnjih uspjeha i neuspjeha (Wolf i Savickas, 1985). Ako je određeno ponašanje u prošlosti po mišljenju osobe bilo zaslužno za uspjeh, kako bi ponovila uspjeh osoba će ponoviti ponašanje. Ako je osoba u sličnoj aktivnosti u prošlosti polučila uspjeh, očekivat će i daljnji uspjeh. Jasno je da zapravo govorimo o bihevioralnim vjerovanjima, odnosno stavu prema ponašanju. Prema Ajzenu i Fisbeinu (1977), upravo je evaluiranje određenog ponašanja kao pozitivnog ili negativnog ono što dovodi do formiranja stava o ponašanju. Takve kategorizacije vrše se temeljem dostupnih informacija, te prethodnih iskustava. Weiner (1985) zaključuje da je atribuiranje uzroka ono što oblikuje emocionalni i bihevioralni odgovor na određeni događaj. Važno je istaknuti da atribucije uzroka nisu uvijek točan odraz realnosti. Ljudi su skloni kategorizaciji atribucija na određeni način. Neki su skloniji uspjehe pripisivati sebi, a neuspjehe drugima, dok kod drugih to nije slučaj. Stoga govorimo o atribucijskom stilu.

Atribucijski stil definiramo kao tendenciju da se pozitivni ili negativni ishodi konzistentno pripisuju specifičnom tipu uzroka (internalni/eksternalni, stabilni/nestabilni itd.) (Harvey i Martinko, 2010). Riječ je o stabilnoj osobini pojedinca, koja se očituje na svim područjima života te je konstantna kroz vrijeme (Gotlib, Lewinsohn, Seely, Rohde i Redner, 1993). Neki autori atribucijski stil čak smatraju karakteristikom ličnosti (Cheng i Furnham, 2003). Ljudi nisu jednako skloni atribuciji uzroka u svakoj situaciji. Veća je vjerojatnost da će uzroke atribuirati događajima koji su im osobno važni, negativni su, predstavljaju prijetnju ili su iznenadni i neočekivani (Weiner, 1983). Važno je napomenuti da kada je situacija potpuno jasna, svi pojedinci će donijeti jednak zaključak o uzroku događaja, bez obzira na atribucijski stil. Međutim, u situacijama koje nisu posve jasne ili postoji dvojba oko uzroka, utjecaj atribucijskog stila bit će mnogo snažniji (Harvey i Martinko, 2010).

Pozitivan (optimističan) atribucijski stil karakteriziraju stabilne, globalne i internalne atribucije uspjeha ili povoljnih ishoda, zbog čega su osobe ovog atribucijskog stila sklone dobro se osjećati u vezi svojih postupaka i sebe kao osobe (Harvey i Martinko, 2010). Osjećaj kompetencije i kontrole koju osoba posljedično osjeća, povećava vjerojatnost adaptivnog funkcioniranja, pa se ovaj atribucijski stil često naziva i adaptivnim (Weiner, 2008). Pojedinci pozitivnog atribucijskog stila uspijevaju zaštititi samopouzdanje pripisujući negativne ishode nestabilnim i specifičnim, te prije svega eksternalnim uzrocima. Stoga ih doživljeni neuspjesi ne sprječavaju u očekivanju budućih pozitivnih ishoda. Razumljivo je da zbog navedenog 
pojedinci ovakvog atribucijskog stila izvještavaju o optimističnijem viđenju budućnosti i posljedično manje stresa u svakodnevnom životu (Weiner, 2008).

Negativan (pesimističan) atribucijski stil, koji se često naziva i neadaptivnim, svojstven je osobama koje su sklone donošenju internalnih, stabilnih i globalnih atribucija negativnih ishoda. Ovakav stil usko je povezan s depresijom, a prema Petersonu i Villanovi (1988) svaka od dimenzija odgovorna je za specifičan aspekt depresije. Internalna objašnjenja negativnih ishoda uzrokuju gubitak samopouzdanja, dimenzija stabilnosti povezana je s bespomoćnošću, a globalne atribucije s deficitima volje. Stoga su pojedinci ovog atribucijskog stila izloženiji većem riziku od pojave depresivnih poremećaja kao odgovora na nepovoljne događaje (Seligman, Abramson, Semmel i von Baeyer, 1979). Budući da osoba ne očekuje buduće uspjehe, javlja se stres, a dolazi i do pada motivacije (Abramson, Seligman i Teasdale, 1978). U ovom kontekstu iznimno je važno istaknuti i dimenziju podložnosti kontroli. U kombinaciji s navedenim atribucijama, osjećaj da pojedinac nema kontrolu nad ishodima posebno je opasan za pojavu depresije. Model naučene bespomoćnosti Abramsona, Seligmana i Teasdalea (1978) u podlogu pojave depresije stavlja upravo negativan atribucijski stil. Pretpostavka modela je da kada osoba doživljava manjak kontrole nad negativnim ishodima dolazi do osjećaja bespomoćnosti. Uz internalnu atribuciju negativnog ishoda, koja vodi padu samopouzdanja, vodi ka depresiji. O dimenzijama stabilnosti i globalnosti ovisi pojavnost depresije, pa tako ako dolazi do stabilne atribucije trajanje depresije će biti duže. Ukoliko pojedinac napravi i globalnu atribuciju, depresivno viđenje će biti obuhvatnije i vezano uz mnoga ili sva područja života (Abramson, Seligman i Teasdale, 1978). Temeljem modela naučene bespomoćnosti, prema Teoriji planiranog ponašanja, atribucijski stil bi trebao biti povezan s percipiranom bihevioralnom kontrolom, u smjeru da osobe negativnog atribucijskog stila doživljavaju osjećaj manje kontrole nad ishodima, odnosno manju subjektivnu sposobnost izvođenja određenog ponašanja.

\section{5. 1. Atribuiranje partnerovog ponašanja}

Recentnija istraživanja govore u prilog postajanja atribucijskih stilova specifičnih domeni, opovrgavajući postojanje globalnog atribucijskog stila (Madeira Graham, 2003). Mjera atribucija u vezi, korištena u ovom istraživanju, dizajnirana je specifično za mjerenje atribucija partnerovog ponašanja, a pokazala se visoko prediktivnom za razvode i bračni distres, te ostaje jednom od najistraživanijih mjera u ovom području (Madeira Graham, 2003). Kako partnerova negativna ponašanja pobuđuju više atribucija od pozitivnih ponašanja (Holtzworth-Munroe i 
Jacobson, 1985), gotovo sva istraživanja partnerskih atribucija koriste upravo negativna ponašanja, zbog čega je odabran upravo ovaj instrument.

Postojeća istraživanja atribucija u interpersonalnom kontekstu većinom se usmjeravaju na dimenziju lokusa kauzalnosti iz dva razloga. Prvo, prema Andersona i Riegeru (1991), ljudi prirodno razmišljaju o atribucijama na dimenzijama lokusa i kontrole, donekle zanemarujući dimenzije stabilnosti i globalnosti. Međutim, kako istraživanja atribucija u bliskim odnosima zahtijevaju od osoba da odrede uzroke ponašanja svojeg partnera, dimenzija podložnosti kontroli počinje sadržavati više faceta. Ona se može odnositi na percipiranu kontrolu nad ponašanjem koju ima partner koji izvodi ponašanje, na kontrolu osobe da spriječi partnera u izvođenju ponašanja ili mogu li ljudi općenito kontrolirati taj uzrok (kontrola koja se odnosi specifično na partnera). Drugi razlog je taj što je lokus kauzalnosti ključan za to hoće li pripisivanje uzroka partnerovog ponašanja rezultirati pozitivnim ili negativnim posljedicama za vezu. Internalna atribucija partnerovog negativnog ponašanja u kombinaciji s prosudbom da je uzrok pod kontrolom partnera imat će pogubniji učinak na vezu u odnosu na eksternalnu atribuciju koja samom eksternalnošću implicira manjak kontrole nad uzrokom. Stoga, hoće li atribucija imati štetan utjecaj na vezu ili neće proizlazi iz dimenzije lokusa, ali ti učinci mogu biti definirani dimenzijama stabilnosti, globalnosti i kontrole.

Kako su uglavnom dominirala istraživanja atribucija u području postignuća, uključivala su tradiciju razmatranja lokusa kauzalnosti kao ili internalnog ili eksternalnog. Takva racionala ima smisla kada razmatramo atribucije koje osobe čine kao odgovor na doživljavanje uspjeha ili neuspjeha, kao i kada nas zanima efekt tih atribucija na kasnije pokušaje u zadacima povezanim s postignućem (Anderson, 1991; Anderson i Slusher, 1986; Weiner, 1985). Dihotomija internalnog- eksternalnog lokusa kauzalnosti u ovakvim okolnostima je logična jer je ishod dihotoman: osoba je postigla ili uspjeh ili neuspjeh u zadatku. U slučaju uspjeha, osoba može pripisati zasluge sebi (npr. naporno je učila, pametna je, što čini internalnu atribuciju) ili situaciji (npr. ispit je bio lagan, što je eksternalna atribucija). U situaciji neuspjeha, također može uzrok pripisati sebi (npr. nije dovoljno pametna) ili situaciji (npr. ispit je bio pretežak). Stoga su u domeni postignuća relevantni uzroci sposobnost, uloženi trud odnosno napor, težina zadatka i sreća (Kamenov, 1991; Graham, 1991; Weiner, 1985). Kako su istraživanja u području postignuća dugo bila okosnica istraživanja atribucija, ne začuđuje da podjela na internalne i eksternalne uzroke zaživjela i u istraživanjima atribucija u interpersonalnim odnosima. Novija istraživanja proširuju dimenziju lokusa kauzalnosti, napominjući važnost uzimanja u obzir interpersonalnog konteksta, posebice interpersonalnog konteksta kao što su romantične veze (Rempel i sur., 2001). No, istraživanja atribucija u području postignuća i 
bliskih odnosa imaju nekoliko ključnih razlika. Prvo, u atribucijama postignuća osobe atribuiraju uzroke ishoda koje su sami doživjeli. U tim okolnostima, internalna atribucija se odnosi na osobu. No, u području bliskih odnosa osobe ne objašnjavaju uzroke svojih ponašanja, već partnerovih ponašanja. Istovremeno, objašnjavaju uzroke partnerovih ponašanja usmjerenih prema njima. Stoga su istovremeno oni koji percipiraju ponašanje i njegov uzrok, ali i objekti partnerovog ponašanja. Kada procjenjivači naprave internalnu atribuciju, određuju određenu partnerovu dispoziciju kao uzrok ponašanja. Suprotno tome, eksternalna atribucija se može odnositi na situacijske faktore (npr. partner doživljava stres na poslu) ili mogu vidjeti sebe kao uzrok partnerovog ponašanja (npr. partner je postupio tako kako je postupio zbog nečega što su oni skrivili, odnosno samookrivljavanje). Međutim, ova distinkcija internalno eksternalno ne zahvaća nužno čitav raspon atribucija koje osobe može napraviti vezano uz partnerovo ponašanje. Točnije, mogu uzrok partnerovog ponašanja pripisati tome što partner osjeća prema njima ili njihovoj vezi, odnosno mogu napraviti takozvanu interpersonalnu atribuciju koja uzrok pronalazi u samom odnosu i dinamici između partnera.

Istraživanja atribucijskog stila u kontekstu intimnih odnosa razvijala su se prilično neovisno o istraživanjima općenitog atribuiranja iz nekoliko razloga. Prvenstveno, istraživanja temeljnih atribucija bazirala su se na ispitivanju atribuiranja vezanih uz strance ili hipotetske osobe, a na temelju vrlo ograničenog seta dostupnih informacija, primjerice opisa hipotetske situacije (Fincham, 2001), što baca sumnju na relevantnost nalaza za kontekst bliskih odnosa. Naime, Knight i Vallacher (1981, prema Fincham, 2001) su pokazali da osobe čine suprotne atribucije ponašanja stranca ako očekuju da će osobu ponovno sresti nekada u budućnosti, u odnosu na situaciju kada vjeruju da su s tom osobom trenutno u interakciji. Kada su vjerovali da su trenutno u interakciji s osobom, njeno pozitivno ponašanje su pripisivale dispozicijskim uzrocima, a negativno situacijskim. Ako su vjerovali da će osobu tek jednom sresti nekada u budućnosti, negativna ponašanja pripisivali su dispozicijama, a pozitivna situaciji. Istovremeno, osobe koje nisu bile u nikakvoj interakciji s osobom o čijem ponašanju donose sud, niti su očekivala da će ikada biti, nisu činile različite atribucije uzroka pozitivnog i negativnog ponašanja. Stoga je razumno za pretpostaviti da će činjenica da su s nekom osobom u trajnom odnosu (vezi) itekako promijeniti način atribuiranja uzorka ponašanja te osobe. Istraživanja atribucija u kontekstu partnerskih odnosa potekla su iz kliničkih saznanja o učestalosti kojom osobe navode stabilne i općenite karakteristike partnera kao uzrok problema u vezi (Kelley, 1979), što je potaklo istraživanja o pripisivanju različitih uzroka negativnih ponašanja od strane osobe koja je ponašanje napravila i njihovog partnera (Orvis i sur., 1976; Passer, Kelley i Michela, 1978; Harvey, Wells i Alvarez, 1978, prema Fincham, 2003). Rana istraživanja 
atribucija u romantičnim vezama predvodili su Fincham, Bradbury i njihovi suradnici (Bradbury i Fincham, 1992; Bradbury, Beach, Fincham, i Nelson, 1996; Fincham, 1985; Fincham, Beach, i Baucom, 1987; Fincham, Beach, i Nelson, 1987; Fincham i Bradbury, 1987, 1988, 1992; 1993; Fincham i O’Leary, 1983; Karney i Bradbury, 1995; Miller i Bradbury, 1995; v. Bradbury i Fincham, 1990 za pregled). Pokušavali su utvrditi obrasce atribuiranja koji čine razliku između zadovoljnih i nezadovoljnih bračnih parova, s fokusom na razvoju strategija koje bi omogućile nezadovoljnim parovima da čine adaptivnije atribucije. Glavni nalaz tih istraživanja bio je da osoba koja je napravila nešto negativno uzrok tog ponašanja traži u situaciji, dok njihov partner ponašanje pripisuje karakteristikama ili stavovima osobe, ali i da način atribuiranja partnerovog ponašanja kovarira sa zadovoljstvom veze. Ako je osoba općenito zadovoljna vezom, bit će sklona partnerovo negativno ponašanje, kao što je zaboravljanje godišnjice, pripisati nestabilnim, specifičnim uzorcima koji su izvan partnera (eksternalni su). Primjerice, može zaključiti da je uzrok ranije spomenuti stres na poslu, dakle privremena situacija, koja se odnosi samo na taj jedan događaj kada je partner zaboravio godišnjicu, te nije posljedica partnerovih karakteristika kao osobe. Na taj način osoba umanjuje značaj negativnog događaja i njegove posljedice za vezu, što pridonosi očuvanju veze. Istovremeno, osoba koja je zadovoljna vezom, pozitivna partnerova ponašanja, kao dobivanje neočekivanog dara od partnera, će pripisati njemu (internalni uzrok), te stabilnim i globalnim uzrocima. Može zaključiti da je partner poklonio neočekivani dar jer je iznimno pažljiv, što je njegova unutarnja karakteristika, stabilna u vremenu i odražava se u svim područjima njihove veze. S druge strane, proces atribuiranja partnerovog ponašanja će biti obrnut ukoliko osoba nije zadovoljna vezom. Tada će negativne događaje pripisivati partneru, te stabilnim i globalnim uzrocima, a pozitivne događaje uzrocima koji su izvan partnera, koji nisu stabilni i specifični su. Takvo atribuiranje postavlja očekivanja i budućih partnerovih negativnih ponašanja, umanjuje zadovoljstvo vezom i stabilnost veze (Fletcher i sur., 2013).

Stil atribuiranja kojim se umanjuju negativni događaji, a naglašavaju pozitivni događaji se često naziva i adaptivnim, dok je neadaptivan stil atribuiranja partnerovog ponašanja onaj kojim se uvećava značaj negativnih događaja, a umanjuje značaj pozitivnih događaja. Odnos načina atribuiranja partnerovog ponašanja i zadovoljstva vezom je recipročan, što znači da adaptivno atribuiranje povećava zadovoljstvo vezom, a zadovoljstvo vezom utječe na način atribuiranja budućih partnerovih postupaka. Uz tri opisane dimenzije atribucija partnerovog ponašanja (internalost, stabilnost i globalnost), posebno se važnima za odnos pokazuju dimenzije sebičnosti, namjere i pripisivanja krivnje, koje zajednički nazivamo pripisivanjem odgovornosti (Simpson i Campbell, 2013). Dok atribucije internalnosti, stabilnosti i globalnosti 
prvenstveno pomažu formiranju očekivanja o budućim partnerovim postupcima, dimenzije sebičnosti namjere i krivnje upućuju na pozadinske motive partnerovog ponašanja koji osobi puno govore o vezi (Holmes, 1981). Način atribuiranja partnerovih ponašanja je prema Teoriji socijalnog učenja direktno povezan s našim reakcijama. Time se stvara zatvoreni krug u kojem pozitivne atribucije vode konstruktivnom ponašanju prilikom sukoba, a negativne atribucije destruktivnim ponašanjima. Stoga očekujemo da će specifični stil atribuiranja ponašanja partnera u intimnom odnosu imati nezavisan doprinos objašnjavanju samog ponašanja, odnosno konstruktivnog rješavanja sukoba. Istraživanja podupiru ovu pretpostavku. Naime, 12mjesečnim longitudinalnim praćenjem parova potvrđeno je da je način atribuiranja koji potiče sukobe (neadaptivan stil atribuiranja) povezan s više negativnih ponašanja tijekom sukoba $u$ vezi (Fincham, 2009). Isto tako, neadaptivne atribucije koje ujedno potiču sukobe povezane su s negativnim afektima koji se javljaju tijekom sukoba, poput ljutnje i plača, smanjenom učinkovitošću pokušaja rješavanja problema i recipročnošću partnerovog negativnog ponašanja. Pritom su utvrđene veze snažnije kod nezadovoljnih parova u odnosu na zadovoljne parove. Krznarić i Kamenov (2016) pokazale su da su osobe koje percipiraju da partner prema njima izražava antagonizam sklone negativne partnerove postupke pripisivati partneru, te stabilnim i globalnim uzrocima, ujedno smatrajući da je partner postupio namjerno negativno, iz sebičnih pobuda, te da ga treba kriviti za takav postupak. Način kako atribuiraju partnerovo negativno ponašanje i percepcija da partner prema njima izražava anatgonizam predviđaju kvalitetu veze, potvrđujući ciklični odnos ponašanja u vezi, percepcije uzroka ponašanja i kvalitete veze.

Budući da je konstruktivno rješavanje sukoba ponašanje koje je pod voljnom kontrolom pojedinca, stav prema takvom načinu rješavanja sukoba, socijalna norma konstruktivnog rješavanja sukoba te percipirani stupanj kontrole koju imamo nad izvođenjem takvog ponašanja, elementi su koji utječu na formiranje namjere konstruktivnog rješavanja sukoba $u$ budućnosti. Postojanje namjere konstruktivne komunikacije prilikom budućih sukoba osnovni je preduvjet stvarnog izvođenja takvog ponašanja, te je namjera ponašanja ujedno najbolji prediktor stvarnog ponašanja. No, u kontekstu konstruktivnog rješavanja sukoba postoje bitni pozadinski faktori koji utječu na formiranje stava o konstruktivnom rješavanju sukoba, socijalne norme izvođenja tog ponašanja te percipirane bihevioralne kontrole nad konstruktivnim rješavajem sukoba. Neki od njih su vremenske perspektive i atribucijski stil pojedinca. Budući da su i vremenske perspektive i atribucijski stil uglavnom stabilni u vremenu, smatramo ih dispozicijama nastalim pod utjecajem ranih iskustava, a koje kao prizma kroz koju filtriramo svakodnevna iskustva utječu na formiranje stavova, socijalnih normi i pecipiranu 
bihevioralnu kontrolu ponašanja. Uz navedene elemente, za konstruktivno rješavanje sukoba bitno je i uvjerenje zašto se partner u vezi ponaša na određeni način, odnosno atribuiranje partnerovog ponašanja u vezi. Ono na način rješavanja sukoba djeluje izravno, izazivajući različitu reakciju ovisno o prosudbi koji se motivi nalaze u pozadini određenog ponašanja koje je partner izveo. Ovisno o pripisanom uzroku partnerovog ponašanja, osoba će različito komunicirati s partnerom u situaciji sukoba. Pretpostavljeni odnos među ovim konstruktima prikazan je na slici 3. Polazeći od njega definirani su sljedeći cilj, problemi i hipoteze istraživanja.

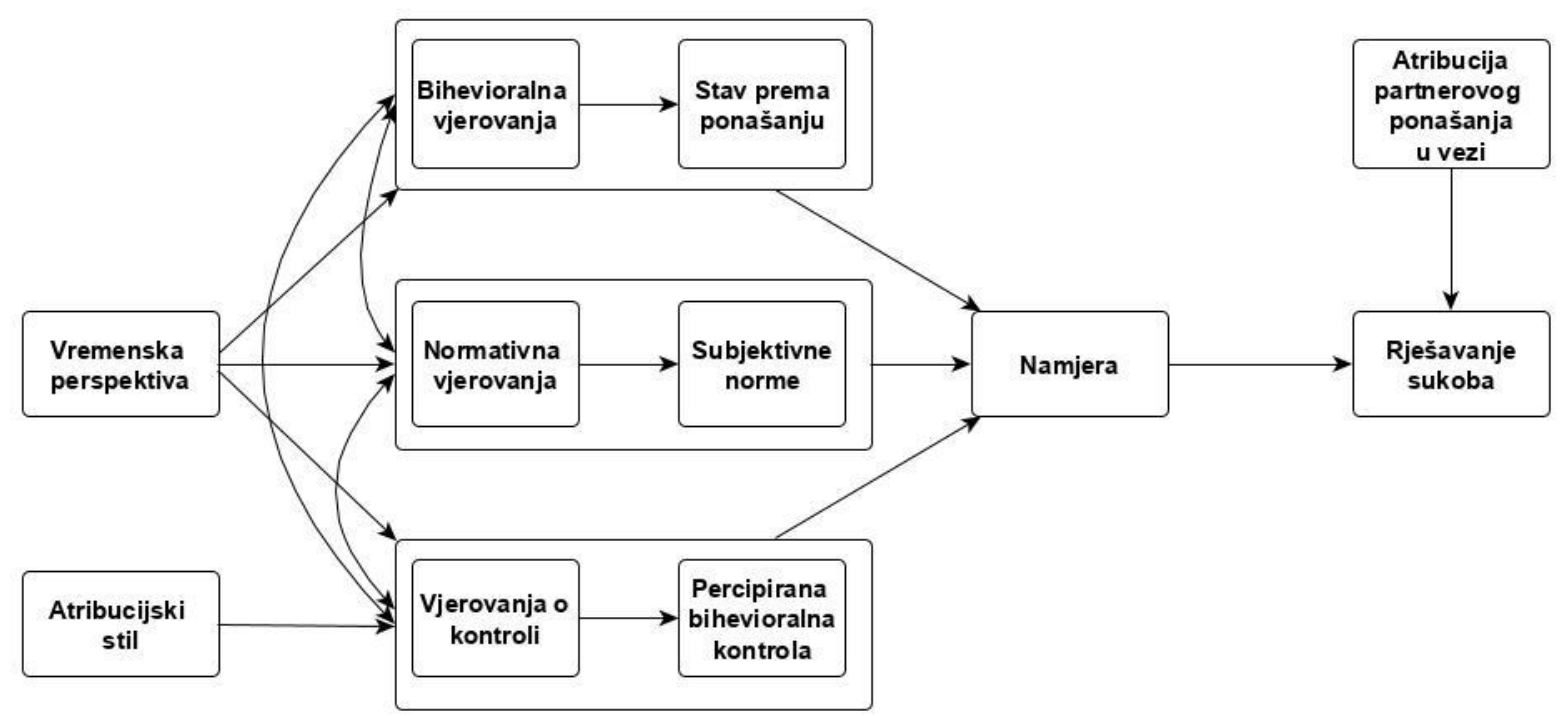

Slika 3. Pretpostavljeni model koji će biti provjeravan u istraživanju. 


\section{CILJ, PROBLEMI I HIPOTEZE ISTRAŽIVANJA}

Cilj istraživanja je ispitati ulogu kognitivnih i motivacijskih odrednica konstruktivne komunikacije pri rješavanju sukoba u intimnim vezama. Specifičnije, provjerit ćemo doprinose li vremenska perspektiva i atribucijski stil, uz elemente koje postulira Teorija planiranog ponašanja (stav prema ponašanju, subjektivne norme o ponašanju, percipirana bihevioralna kontrola) boljem predviđanju ponašanja osoba prilikom sukoba. Drugim riječima, testirat ćemo model u kojem vremenska perspektiva i atribucijski stil preko elemenata Teorije planiranog ponašanja djeluju na namjeru, a potom preko namjere i na konstruktivnu komunikaciju prilikom sukoba. Namjera predstavlja posredujuću varijablu (medijator) između ranije navedenih konstrukata i ciljnog ponašanja, odnosno konstruktivne komunikacije prilikom sukoba.

U skladu s ciljem istraživanja, formulirani su sljedeći problem $(\mathrm{P})$ i hipoteze $(\mathrm{H})$ :

P 1: Ispitati povezanost stava prema ponašanju, subjektivne norme i percipirane bihevioralne kontrole objašnjenju namjere za konstruktivno rješavanje sukoba i konstruktivnog rješavanja sukoba.

H 1: Pozitivan stav prema konstruktivnom rješavanju sukoba, izraženija subjektivna norma konstruktivne komunikacije, te viša percipirana bihevioralna kontrola pozitivno su povezani s namjerom konstruktivne komunikacije i izraženošću ciljnog ponašanja, odnosno konstruktivnog rješavanja sukoba.

P 2: Ispitati povezanost namjere ponašanja i ciljnog ponašanja, odnosno stvarne konstruktivne komunikacije prilikom sukoba.

H 2: Namjera konstruktivne komunikacije prilikom budućih sukoba pozitivno je povezana sa stvarnom konstruktivnom komunikacijom prilikom sukoba u sljedećih mjesec dana.

P 3: Ispitati povezanost pojedinih vremenskih perspektiva i stava prema konstruktivnom rješavanju sukoba, subjektivne norme za izvođenje tog ponašanja, te percipirane bihevioralne kontrole.

H 3a: Orijentacije na pozitivnu prošlost, hedonističku sadašnjost i budućnost pozitivno koreliraju sa stavom prema konstruktivnom rješavanju sukoba.

H 3b: Orijentacije na hedonističku i fatalističku sadašnjost negativno koreliraju sa subjektivnom normom izvođenja ponašanja.

H 3c: Fatalistička sadašnjost negativno korelira sa percipiranom bihevioralnom kontrolom.

P 4: Ispitati povezanost atribucijskog stila i percipirane bihevioralne kontrole. 
H 4: Pozitivan atribucijski stil bit će pozitivno, a negativan atribucijski stil negativno povezan s percipiranom bihevioralnom kontrolom.

P 5: Ispitati povezanost specifičnog atribucijskog stila $u$ kontekstu intimne veze $i$ konstruktivnog rješavanja sukoba.

H 5: Osobe koje pozitivnije atribuiraju ponašanje partnera u intimnoj vezi bit će sklonije konstruktivnom rješavanju sukoba, dok će sklonost negativnom atribuiranju ponašanja partnera biti povezana s destruktivnim ponašanjima prilikom sukoba.

P 6: Ispitati doprinose li vremenske perspektive $i$ atribucijski stil, te atribucije ponašanja partnera u intimnoj vezi dodatnom objašnjenju konstruktivnog ponašanja prilikom sukoba, uz elemente Teorije planiranog ponašanja (stava prema ponašanju, subjektivne norme o izvođenju ponašanja, percipirane bihevioralne kontrole).

H 6: Vremenske perspektive, atribucijski stil, te atribucije ponašanja partnera u intimnoj vezi imaju statistički značajan inkrementalni doprinos objašnjenju konstruktivnog ponašanja prilikom sukoba, povrh doprinosa koji imaju varijable proizašle iz Teorije planiranog ponašanja. Drugim riječima, Prošireni model Teorije planiranog ponašanja objašnjava statistički značajno više varijance konstruktivnog ponašanja od osnovnog modela Teorije planiranog ponašanja. 


\section{METODOLOGIJA}

Kako bismo odgovorili na postavljene probleme i provjerili predloženi model, provedeno je kvantitativno istraživanje u dvije vremenske točke, između kojih je bio vremenski odmak od mjesec dana. Budući da se istraživanje bavilo predviđanjem konstruktivne komunikacije prilikom sukoba, u prvoj točki mjerenja glavnog istraživanja ispitani su prediktori konstruktivne komunikacije prilikom sukoba. Mjesec dana kasnije, provjerena je stvarna konstruktivna komunikacija prilikom sukoba koji su se u vezi dogodili u proteklih mjesec dana. Time je omogućeno sigurnije zaključivanje o prediktivnosti ispitivanih faktora, budući da je nužno da prediktori vremenski prethode kriteriju.

Prije opisa metodologije glavnog istraživanja, čiji su rezultati primarni interes ovog rada, bilo je potrebno provesti nekoliko faza predistraživanja. U nastavku će se detaljnije opisati tijek predistraživanja i zaključci proizašli iz analiza rezultata dobivenih predistraživanjem. Kako je osnovni cilj predistraživanja bila konstrukcija mjere namjere konstruktivne komunikacije prilikom sukoba prema Teoriji planiranog ponašanja, konzultacije sa studentima (Tablica 1) koje su prve provedene, omogućile su generiranje preliminarnih čestica spomenute mjere koje su pridružene preliminarnim česticama konstruiranim temeljem ranijih spoznaja o sukobima u vezama. U prvoj fazi predistraživanja primijenjena je preliminarna verzija tako formirane mjere namjere konstruktivne komunikacije prilikom sukoba, te preliminarna verzija prevedene Mjere atribucija u vezi (Fincham i Bradbury, 1992). Studenti su pritom naveli i eventualne teškoće ili nejasnoće s kojima su se susreli tijekom ispunjavanja upitnika, te ponudili prijedloge za poboljšanje. Uvažavajući prijedloge studenata, kao i temeljem metrijskih karakteristika utvrđenih prvom fazom predistraživanja, formirane su konačne verzije instrumenata koje su primijenjene u drugoj fazi predistraživanja. Druga faza predistraživanja predstavljala je preliminarnu primjenu svih instrumenata koji će biti korišteni u glavnom istraživanju jednakim postupkom kao što je bilo predviđeno za glavno istraživanje. Stoga je druga faza predistraživanja provedena u dvije vremenske točke, kao i glavno istraživanje.

U Tablici 1. prikazani su svi koraci koji su prethodili glavnom istraživanju, kao i koraci glavnog istraživanja. Uz objašnjenje svih koraka predistraživanja i glavnog istraživanja, pojasnit će se postupak formiranja uzorka sudionika predistraživanja i glavnog istraživanja. 
Tablica 1. Prikaz strukture istraživanja i predistraživanja

\begin{tabular}{|c|c|c|c|c|c|}
\hline \multicolumn{4}{|c|}{ PREDISTRAŽIVANJE } & \multicolumn{2}{|c|}{ GLAVNO ISTRAŽIVANJE } \\
\hline \multirow{2}{*}{$\begin{array}{c}\text { Konzultacije sa } \\
\text { studentima }\end{array}$} & \multirow{2}{*}{$\begin{array}{c}\text { 1. faza } \\
\text { predistraživanja }\end{array}$} & \multicolumn{2}{|c|}{ 2. faza predistraživanja } & \multirow[t]{2}{*}{ 1. točka mjerenja } & \multirow[t]{2}{*}{ 2. točka mjerenja } \\
\hline & & 1. točka mjerenja & 2. točka mjerenja & & \\
\hline $\begin{array}{l}\text { 1. } \text { Otvoreni upitnik za } \\
\text { generiranje čestica } \\
\text { Mjere namjere } \\
\text { konstruktivne } \\
\text { komunikacije } \\
\text { prilikom sukoba }\end{array}$ & $\begin{array}{ll}\text { 1. } & \text { Dob i spol } \\
\text { 2. } & \text { Duljina veze } \\
\text { 3. } & \text { Preliminarna } \\
& \text { verzija Mjere } \\
\text { namjere } \\
\text { konstruktivne } \\
\text { komunikacije } \\
\text { prilikom sukoba } \\
\text { 4. } & \begin{array}{l}\text { Preliminarna } \\
\text { verzija Mjere }\end{array} \\
\text { atribucija u vezi } & \text { Indeks kvalitete } \\
\text { veze }\end{array}$ & $\begin{array}{ll}\text { 1. } & \begin{array}{l}\text { Sociodemografska } \\
\text { pitanja }\end{array} \\
\text { 2. } & \text { Mjere namjere } \\
& \text { konstruktivne } \\
& \text { komunikacije prilikom } \\
& \text { sukoba } \\
\text { 3. } & \text { Mjera atribucija u vezi } \\
\text { 4. } & \text { Zimbardov inventar } \\
& \text { vremenskih } \\
\text { perspektiva }\end{array}$ & $\begin{array}{ll}\text { 1. } & \text { Upitnik } \\
\text { komunikacijskih } \\
\text { obrazaca prilikom } \\
\text { sukoba }\end{array}$ & $\begin{array}{ll}\text { 1. } & \text { Sociodemografska } \\
\text { pitanja } \\
\text { 2. }\end{array}$ & $\begin{array}{l}\text { 1. Subskala } \\
\text { konstruktivne } \\
\text { komunikacije } \\
\text { Upitnika } \\
\text { komunikacijskih } \\
\text { obrazaca prilikom } \\
\text { sukoba }\end{array}$ \\
\hline
\end{tabular}




\subsection{Predistraživanje}

Ciljevi predistraživanja bili su 1. konstrukcija mjere namjere konstruktivne komunikacije prilikom sukoba prema Teoriji planiranog ponašanja, te 2. prijevod i provjera metrijskih karakteristika hrvatske inačice Mjere atribucija u vezi. U nastavku bit će opisan postupak konstrukcije Mjere namjere konstruktivne komunikacije prilikom sukoba, te postupak prijevoda i provjere metrijskih karakteristika Mjere atribucija u vezi na hrvatski jezik.

\subsubsection{Konzultacije sa studentima i prva faza predistraživanja}

\section{$\underline{\text { Konstrukcija Mjere namjere konstruktivne komunikacije prilikom sukoba }}$}

Kako je za svako istraživano ciljno ponašanje nužno konstruirati specifičan upitnik Teorije planiranog ponašanja, osnovna svrha provedenih konzultacija sa studentima i predistraživanja bila je konstrukcija takvog upitnika, te validacija instrumenata koji ranije nisu korišteni na hrvatskim uzorcima. Upitnik je konstruiran slijedom koraka definiranih smjernicama Icaka Ajzena (http://people.umass.edu/ aizen/pdf/tpb.measurement.pdf, preuzeto 28.12.2017.). Za konstrukciju upitnika ključno je definiranje konstruktivne komunikacije prilikom sukoba u terminima cilja, ponašanja, konteksta i vremenskih elemenata, te je konstruktivna komunikacija kao način rješavanja sukoba definirana kao ponašanje koje uključuje otvorenu rasprava o konfliktnim temama, slobodno i pozitivno izražavanje emocija te zajednički trud oko postizanja rješenja u sukobu (Bradbury i Karney, 2014). Kao ciljna populacija određenu su osobe u dobi od 18 do 30 godina koje su trenutno u romantičnoj vezi. Kako bismo generirali čestice direktne mjere potrebne za konstrukciju upitnika osmišljeno je pet do šest čestica za procjenu svakog od glavnih konstrukata modela (stav, percipirana norma, percipirana bihevioralna kontrola i namjera). Čestice su utemeljene na spoznajama proizašlim iz literature i ranijim istraživanjima. Istovremeno je $u$ fazi konzultacija sa studentima na manjem uzorku studenata preddiplomskog studija psihologije Filozofskog fakulteta u Zagrebu $(N=29)$ primijenjen upitnik otvorenog oblika vezan uz konstruktivnu komunikaciju prilikom sukoba (Prilog 1.). Temeljem sadržajne analize odgovora ove grupe sudionika generirane su čestice koje su pridodane česticama direktnih mjera, te su zajedno sačinjavale preliminarnu verziju Mjere namjere konstruktivne komunikacije prilikom sukoba.

Preliminarni upitnik Mjere namjere konstruktivne komunikacije prilikom sukoba sadržavao je definiciju ciljnog ponašanja, navedenu kako ne bi među sudionicima postojala nedoumica što je konstruktivna komunikacija prilikom sukoba. Uključivao je 72 čestice, a 
zadatak sudionika bio je ocijeniti učestalost određenog ponašanja (npr. „Koliko često Vaša partnerica nije bila voljna ili spremna na konstruktivno rješavanje sukoba"?), dati stupnjevani vrijednosni sud određenog ponašanja (npr. „Za mene je konstruktivno rješavanje sukoba u vezi vrlo neugodno - vrlo ugodno.“) ili izraziti stupanj slaganja s tvrdnjom (npr. „Uvjeren sam da kad bih htio da bih mogao konstruktivno rješavati sukobe u vezi. "). Odgovori na sve čestice davani su odabirom jedne od vrijednosti na skali sa sedam uporišnih točaka.

U prvoj fazi predistraživanja korišten je prigodan uzorak studenata psihologije, koji su sačinjavale 164 osobe $u$ rasponu dobi od 18 do 21 godine $(\mathrm{M}=21.10, \mathrm{SD}=1.95)$. Uzorak je činilo 128 žena (78\%) i 36 muškaraca (22\%). Svi sudionici su u trenutku sudjelovanja bili u ljubavnoj vezi.

Kao što je ranije navedeno, osnovni cilj provedbe predistraživanja bila je konstrukcija i provjera metrijskih karakteristika Mjere namjere konstruktivne komunikacije prilikom sukoba. Pri odabiru čestica za konačnu verziju Mjere namjere konstruktivne komunikacije prilikom sukoba razmatrani su deskriptivni pokazatelji, indeksi asimetričnosti (eng. skewness) i spljoštenosti distribucija (eng. kurtosis), nespuriozna korelacija čestice i ukupnog rezultata na subskali (eng. corrected item-total correlation) te pouzdanost skale koja ne sadrži tu česticu (eng. Cronbach's Alpha if item deleted) (Prilog 7). U konačnu verziju uključivane su čestice većeg varijabiliteta, koje ne pokazuju izraženija odstupanja od normalne distribucije, visoko koreliraju s ukupnim rezultatom na skali, a da pritom ne umanjuju pouzdanost skale kojoj pripadaju. Istovremeno se uvažavao i sadržajni kriterij, kako ne bi bilo zadržano više sličnih tvrdnji koje ne donose nove informacije o konstruktu. Naposljetku, kako u upitniku postoje korespondentne tvrdnje koje se razmatraju u paru, izbacivana je i korespondentna čestica neodgovarajuće tvrdnje. Za odabir čestica za konačnu verziju instrumenta ključna je bila konfirmatorna faktorska analiza provedena na mjernim modelima pojedinih elemenata Mjere namjere konstruktivne komunikacije prilikom sukoba, o čemu će više riječi biti u potpoglavlju 4.2.1.

\section{Prijevod i provjera hrvatske verzije Mjere atribucija u vezi}

Drugi cilj predistraživanja bio je prijevod i provjera hrvatske verzije Mjere atribucija u vezi, budući da je riječ o instrumentu koji ranije nije primjenjivan na hrvatskim uzorcima niti je postojao hrvatski prijevod. Mjera atribucija u vezi (eng. Relationship Attribution Measure, $R A M)$ autora Finchama i Bradburyja (1992) procjenjuje atribucijski stil pojedinca u kontekstu intimne veze. Ovom mjerom od 28 čestica identificira se tip atribucija koje sudionik čini za partnerovo negativno ponašanje. Mjera navodi 4 hipotetska negativna postupka partnera (npr. 
„,Vaša djevojka kritizira nešto što ste rekli“), a sudionik ocjenjuje vjerojatan uzrok takvog ponašanja pomoću skale sa 6 uporišnih točaka duž 6 dimenzija: lokus, stabilnost, globalnost, te namjeru, sebičnost i krivnju. Kombinacijom posljednje tri dimenzije formira se tzv. indeks odgovornosti. Temeljem ovog instrumenta može se izračunati više rezultata (prema navedenim dimenzijama ili ukupni rezultat), ovisno o specifičnom cilju istraživanja. Za potrebe ovog istraživanja korištene su mjere za svih 6 dimenzija: lokus odnosno internalnost, stabilnost, globalnost, namjera, sebičnost i krivnja, koje se dobivaju jednostavnom linearnom kombinacijom istovjetnih čestica kroz 4 hipotetske situacije.

Mjera atribucija u vezi prevedena je za potrebe ovog istraživanja dvostrukim prijevodom na hrvatski jezik (vidi Prilog 3.). Dvostruki prijevod omogućava usporedbu točnosti i kvalitete prijevoda s originalnim instrumentom, a proveden je na način da je autorica ovog rada prevela originalni instrument s engleskog na hrvatski jezik, te je potom nezavisni prevoditelj, neupućen u originalni instrument, preveo Mjeru atribucija u vezi s hrvatskog na engleski jezik. Potom su uspoređene originalna Mjera atribucija u vezi na engleskom jeziku i engleska verzija istog instrumenta dobivena dvostrukim prijevodom. Kako nije bilo značajnih sadržajnih odstupanja između spomenute dvije verzije, zaključeno je kako je hrvatski prijevod Mjere atribucija u vezi prikladan i primjeren za provedbu daljnjih koraka istraživanja. Temeljem rezultata provedenog predistraživanja, te provjerom metrijskih karakteristika, hrvatska verzija Mjera atribucija u vezi se pokazala primjerenom za daljnju upotrebu, te zadovoljavajućih metrijskih karakteristika (Prilog 3). Faktorskom analizom dobiveno je jednofaktorsko rješenje kojim je objašnjeno $22 \%$ varijance. Pouzdanost čitave skale iznosila je $\alpha=.86$. Pouzdanost subskala bila je sljedeća: lokus $\alpha=.69$, stabilnost $\alpha=.73$, globalnost $\alpha=$ .55 , namjera $\alpha=.65$, sebičnost $\alpha=.69$ i krivnja $\alpha=.70$.

\subsubsection{Druga faza predistraživanja}

Cilj druge faze predistraživanja, osim provjere konačnih verzija svih instrumenata za koje je planirano korištenje u glavnom istraživanju, bila je i provjera prikladnosti svih elemenata postupka istraživanja, kao što je regrutacija anketara sudionika, sustav dodjeljivanja šifri sudionicima i slično. U svrhu provedbe druge faze predistraživanja, regrutirani su studenti psihologije za ulogu pomoćnih anketara. Na osnovi procjene studenata koliko sudionika u dobi od 18 do 30 godina koji su trenutno u ljubavnoj vezi mogu prikupiti, dodijeljen im je odgovarajući broj papirnatih upitnika. Sudionici su na upitniku trebali navesti šifru poznatu samo njima, koja je služila uparivanju podataka istog sudionika u obje točke mjerenja. Upitnike 
su vraćali putem studenata anketara u zalijepljenoj kuverti. U prvoj točki mjerenja druge faze predistraživanja primijenjene su konačne verzije Mjere namjere konstruktivne komunikacije u sukobu, konačna hrvatska verzija Mjere atribucija u vezi te Zimbardov upitnik vremenskih perspektiva, kao mjere prediktora konstruktivne komunikacije prilikom sukoba. Nakon mjesec dana sudionicima je proslijeđena poveznica na online upitnik napravljen u sustavu SurveyMonkey, što je predstavljalo drugu točku mjerenja. U drugoj točki mjerenja primijenjen je Upitnik komunikacijskih obrazaca prilikom sukoba, a u daljnje analize uključeni su podaci dobiveni na subskali konstruktivne komunikacije, što je predstavljalo mjeru kriterija. Detaljan opis ovog instrumenta nalazi se u Potpoglavlju 3.2.3.

U prvoj točki mjerenja upitnik je ispunilo 335 sudionika, no potpune podatke u obje točke mjerenja je imalo svega 110 sudionika, od čega 37 muškaraca (33.6\%) i 73 žene (66.4\%). Sudionici su imali između 18 i 30 godina, prosječne dobi 21.5 godina (SD = 3.037). Svi sudionici su u trenutku sudjelovanja bili u ljubavnoj vezi koju su procjenjivali ozbiljnom, ali ne u braku, a 8 sudionika (7.3\%) je živjelo s partnerom/icom. Većina sudionika odrasla je u velikom gradu (49.1\%) ili gradu s do 500000 stanovnika (7.3\%), a manje je bilo onih iz manjih gradova $(24.5 \%)$ te sela $(18.2 \%)$.

Uočeno je da je znatan broj sudionika $(N=97)$ ispunio online upitnik u drugoj točki mjerenja no navedena šifra se nije podudarala niti s jednom šifrom u prvoj točki mjerenja, zbog čega podatke nije bilo moguće upariti. Ovakav ishod sugerirao je da je potrebno modificirati postupak prikupljanja podataka u glavnom istraživanju, budući da se dio sudionika vjerojatno nije sjećao šifre koju su naveli u prvoj točki mjerenja. Studenti su za sudjelovanje u konzultacijama i obje faze predistraživanja regrutirani direktnim pozivom na sudjelovanje od strane nastavnika, te putem informacija objavljenih na mrežnim stranicama Odsjeka za psihologiju Filozofskog fakulteta u Zagrebu. Za sudjelovanje su nagrađeni eksperimentalnim satima, vrstom bodova čiji određeni broj moraju prikupiti tijekom studija kao sastavni dio programa studija psihologije. 


\subsection{Glavno istraživanje}

\section{$\underline{\text { 3.2.1. Postupak }}$}

Glavno istraživanje provedeno je početkom 2016. godine online putem, uz pomoć studenata psihologije. Studenti psihologije su tijekom nastave regrutirani za sudjelovanje u istraživanju u ulozi pomoćnih istraživača. U ulozi studenta anketara u istraživanju je sudjelovao 71 student preddiplomskog i diplomskog studija psihologije, a za pomoć u provođenju istraživanja nagrađeni su eksperimentalnim satima. Objašnjena im je svrha istraživanja, postupak koji će ono uključivati te su studenti zainteresirani za sudjelovanje trebali procijeniti koliko sudionika mogu prikupiti i ostaviti e-mail adresu doktorandici. Doktorandica je potom stupila u kontakt sa svakim pojedinim studentom, poslavši mu na e-mail adresu točan broj šifri ovisno o pretpostavci studenta koliko će sudionika prikupiti. Uz šifre, studenti su primili uputu studentima anketarima, uputu sudionicima, te uputu uz upitnik. Zadatak studenata anketara je bio regrutirati sudionike za istraživanje u dobi od 18 do 30 godina koji se trenutno nalaze $u$ vezi, te im proslijediti šifru specifičnu za sudionika, uputu sudionicima, uputu uz upitnik te link na online istraživanje. Ovakvim postupkom omogućeno je da sudionici imaju u pisanoj formi svoju šifru koju su trebali upisati u obje vremenske točke kako bi se povezali podaci istog sudionika. Istovremeno postupak je jamčio potpunu anonimnost budući da doktorandica nije znala kome je dodijeljena koja šifra, a student anketar nije imao pristup podacima. Sudionike smo uputom zamolili da na sve upitnike odgovaraju pažljivo i iskreno, te im naglasili da je istraživanje anonimno. Obavijestili smo ih da ćemo ih nakon mjesec dana ponovno kontaktirati kako bi ispunili upitnike predviđene drugom točkom mjerenja.

Glavno istraživanje provedeno je u dvije vremenske točke (Tablica 2) putem online sustava SurveyMonkey. Sustav je jednostavan za korištenje te nisu bile očekivane poteškoće s obzirom na dob sudionika koja ukazuje barem na bazično snalaženje s računalima. U prvoj vremenskoj točki ispitani su konstrukti modela Teorije planiranog ponašanja koristeći novokonstruiranu Mjeru namjere konstruktivne komunikacije prilikom sukoba te konstrukti vremenske perspektive, atribucijskog stila, atribuiranja partnerovog negativnog ponašanja, te kvalitete veze. Kako bismo upitnike mogli povezati s drugim upitnikom koji će ispunjavati, od sudionika smo tražili da upišu šifru koja im je dodijeljena. Točan redoslijed primijenjenih upitnika prikazan je u Tablici 2.

Mjesec dana nakon ispunjavanja prvog upitnika, sudionicima je upućen link na drugi upitnik uz uputu i molbu da se odazovu istraživanju. U drugoj točki mjerenja primijenjen je Upitnik komunikacijskih obrazaca prilikom sukoba koji je sadržavao subskalu Konstruktivne 
komunikacije kao ciljnog ponašanja u ovom istraživanju. Uz spomenuti upitnik, sudionicima je postavljeno i pitanje jesu li još uvijek u vezi $\mathrm{s}$ istom osobom $\mathrm{s}$ kojom su bili prilikom ispunjavanja prvog upitnika. Podaci sudionika koji više nisu bili u vezi s istom osobom isključeni su iz daljnjih analiza. Po ispunjavanju upitnika druge točke mjerenja, sudionicima je upućen e-mail zahvale za sudjelovanje te adresa na koju se mogu obratiti ukoliko ih zanimaju rezultati provedenog istraživanja.

Tablica 2. Instrumenti primijenjeni u 1. i 2. točki mjerenja

\begin{tabular}{|c|c|c|}
\hline & Instrument & Konstrukt(i) \\
\hline \multirow{5}{*}{ 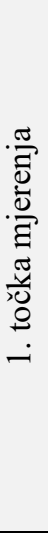 } & Demografski podaci & Dob, spol, trajanje veze \\
\hline & $\begin{array}{l}\text { Mjera namjere konstruktivne } \\
\text { komunikacije prilikom sukoba }\end{array}$ & $\begin{array}{l}\text { Stav, percipirana norma, percipirana bihevioralna } \\
\text { kontrola i namjera ponašanja vezani uz konstruktivnu } \\
\text { komunikaciju prilikom sukoba }\end{array}$ \\
\hline & Mjera atribucija u vezi & Atribucije uzroka partnerovog negativnog ponašanja \\
\hline & $\begin{array}{l}\text { Zimbardov inventar vremenskih } \\
\text { perspektiva }\end{array}$ & $\begin{array}{l}\text { Izraženost vremenskih perspektiva prošlosti negativne, } \\
\text { prošlosti pozitivne, sadašnjosti fatalističke, sadašnjosti } \\
\text { hedonističke, te budućnosti }\end{array}$ \\
\hline & Upitnik atribucijskog stila & Izraženost pozitivnog/ negativnog atribucijskog stila \\
\hline 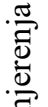 & Pitanje o statusu veze & $\begin{array}{l}\text { Je li sudionik } \mathrm{i} \text { dalje } \mathrm{u} \text { vezi } \mathrm{s} \text { istom osobom od prije } \\
\text { mjesec dana }\end{array}$ \\
\hline $\begin{array}{l}\text { i } \\
\frac{\pi}{0} \\
0 \\
\text { i }\end{array}$ & $\begin{array}{l}\text { Upitnik komunikacijskih obrazaca } \\
\text { prilikom sukoba (subskala } \\
\text { Konstruktivne komunikacije) }\end{array}$ & Konstruktivna komunikacija prilikom sukoba u vezi \\
\hline
\end{tabular}

\subsubsection{Sudionici}

Istraživanje je provedeno na prigodnom uzorku 240 sudionika u dvije točke mjerenja. Uzorak su činile mlade odrasle osobe u dobi od 18 do 30 godina $(M=21.9 ; S D=3.01)$ koje za sebe izjavljuju da su trenutno u ozbiljnoj ljubavnoj vezi. Uzorak je sačinjavalo 50,4\% žena. Sudionici su bili u vezama trajanja od 1 mjeseca do 120 mjeseci $(M=29.56 ; S D=23.57)$, a većina sudionika (87.5\%) ne živi s partnerom. Većinu uzorka čine mlade osobe iz cjelovitih obitelji, a svega 9.2\% sudionika izjavljuje da su im roditelji razvedeni. Uzorak je heterogen prema veličini mjesta iz kojega sudionici potječu: $22.5 \%$ sudionika dolazi iz sela ili manjeg mjesta (do 10000 stanovnika), 32.1\% iz manjeg grada (do 100000 stanovnika), 8.8\% iz gradova s do 500000 stanovnika, a 36.7\% uzorka čine sudionici koji dolaze iz mjesta s više od 500000 stanovnika. 
Sudionici su bili regrutirani putem društvene mreže studenata psihologije i same doktorandice. Sudionicima je bilo rečeno da se radi o doktorskom istraživanju na temu bliskih odnosa, a čije rezultate će moći dobiti na zahtjev po završetku istraživanja. U prvoj točki mjerenja sudjelovala su 322 sudionika, a drugoj točki mjerenja odazvala su se 242 sudionika, što ukazuje na osipanje uzorka u odnosu na 1 . točku mjerenja u visini od $25.16 \%$. Iz daljnje obrade su isključeni i podaci jednog sudionika koji u drugoj točki mjerenja više nije bio u vezi ili nije više bio $\mathrm{u}$ vezi $\mathrm{s}$ istom osobom kao u prvoj točki mjerenja. Zbog odstupanja $u$ predviđenoj dobi, jedan sudionik isključen je iz daljnjih obrada, te konačni uzorak ovog istraživanja čini 240 sudionika.

\subsubsection{Instrumenti}

\section{$\underline{\text { Mjera namjere konstruktivne komunikacije prilikom sukoba }}$}

Mjera namjere konstruktivne komunikacije prilikom sukoba u sukobu konstruirana je za potrebe ovog istraživanja, te testirana predistraživanjem. U glavnom istraživanju primijenjena je verzija upitnika od 72 čestice sa 7 uporišnih točaka, a potom je provedena konfirmatorna faktorska analiza (vidi potpoglavlje 4.2.1.), temeljem koje je broj čestica reduciran na 38. Početna verzija upitnika od 72 čestice uključivala je i direktne mjere stava (4 čestice, npr. Konstruktivno rješavanje sukoba u vezi za mene je iznimno loše/iznimno dobro.), subjektivne norme (4 čestice, npr. Od mene se očekuje da konstruktivno rješavam sukobe u vezi.) i percipirane bihevioralne kontrole (5 čestica, npr. Hoću li ili neću konstruktivno rješavati sukobe u vezi ovisi isključivo o meni.,) kao i mjere faktora nižeg reda čijim se množenjem dobivaju mjere stava, subjektivne norme i percipirane bihevioralne kontrole. Mjere faktora nižeg reda čiji umnožak predstavlja mjeru stava su bihevioralna vjerovanja (11 čestica, npr. Konstruktivno rješavanje sukoba unaprijedit će našu vezu.) i subjektivna vrijednost očekivanog ishoda (11 čestica, Unaprijediti našu vezu za mene bi bilo iznimno loše/iznimno dobro.), a riječ je o korespondentnim tvrdnjama. Korespondentne tvrdnje su i čestice normativnih deskriptivnih vjerovanja (5 čestica, npr. Moji roditelji smatraju da trebam konstruktivno rješavati sukobe u vezi.) i motivacije za postupanje u skladu s tuđom željom (5 čestica, npr. Općenito govoreći, koliko Vam je stalo do toga što Vaši roditelji misle da biste trebali činiti?), čiji umnožak predstavlja mjeru subjektivne norme. Mjeru subjektivne norme čine i umnošci subjektivne injunktivne norme (5 čestica, npr. Mislite li da će Vaše ženske prijateljice u budućnosti komunicirati konstruktivno prilikom sukoba?) i mjera jesu li sudioniku određene osobe uzori (5 
čestica, npr. Jesu li Vam Vaše ženske prijateljice uzor kako se treba ponašati u vezi?). Mjera percipirane bihevioralne kontrole dobivena je množenjem mjera kontrolnih vjerovanja (7 čestica, npr. Kada bi me moje emocije potpuno obuzele, to bi mi otežalo konstruktivno komuniciranje prilikom sukoba.) i snage kontrolnih faktora (7 čestica, npr. Koliko često Vas Vaše emocije potpuno obuzmu?), kao mjera nižeg reda. Zadatak sudionika je na skali sa 7 uporišnih točaka izraziti vrijednosni sud vezan uz konstruktivnu komunikaciju (npr. Konstruktivno rješavanje sukoba u vezi za mene je 1- dosadno do 7-zanimljivo), izraziti stupanj slaganja s pojedinom tvrdnjom (npr. Većina ljudi čije mišljenje cijenim bi odobravala da konstruktivno rješavam sukobe $u$ vezi., 1- u potpunosti se ne slažem do 7- u potpunosti se slažem), te učestalost pojedinih događaja (npr. Koliko često prisutnost $i$ uplitanje drugih osoba ometa rješavanje sukoba između Vas i Vaše/g partnera/ice?, 1- jako rijetko do 7- jako često).

Postupkom konfirmatorne faktorske analize, o čemu će više riječi biti u potpoglavlju 4.2.1., ispitani su mjerni modeli obje varijante mjera. Temeljem provedenih analiza, čestice umnožaka pokazale su se prikladnijom mjerom stava, subjektivne norme i percipirane bihevioralne kontrole. Podaci za konfirmatorne faktorske analize direktnih mjera stava, subjektivne norme i percipirane bihevioralne kontrole nalaze se u Prilozima 8d i 8e. Množenjem korespondentnih čestica dobiveno je 19 umnožaka koji su ušli u daljnju analizu, uz četiri čestice direktne mjere namjere, što rezultira s ukupno 42 čestice početnog upitnika na kojima su rađene daljnje analize. Faktorska analiza provedena na česticama stava, subjektivne norme i percipirane bihevioralne kontrole pokazala je jasno trofaktorsko rješenje, kojim je objašnjeno ukupno 38.52\% varijance. Pouzdanost subskale stava u glavnom istraživanju iznosila je $\alpha=$ .88 , subskale subjektivne norme $\alpha=.84$, te percipirane bihevioralne kontrole $\alpha=.66$.

\section{$\underline{\text { Mjera atribucija u vezi }}$}

Mjera atribucija u vezi (eng. Relationship Attribution Measure, RAM) autora Finchama i Bradburyja (1992) jedan je od instrumenata koji ispituje atribucijski stil specifičan za domenu, omogućava procjenu atribucijskog stila pojedinca u kontekstu intimne veze. Preveden je za potrebe ovog istraživanja dvostrukim prijevodom na hrvatski jezik (vidi Prilog 3.). Sadrži 28 čestica pomoću kojih se identificira tip atribucija koje sudionik čini za partnerovo negativno ponašanje. Mjera se sastoji od opisa 4 hipotetska negativna postupka partnera (npr. „Vaša djevojka kritizira nešto što ste rekli“), a zadatak sudionika je pomoću skale sa 6 uporišnih točaka vjerojatan uzrok takvog ponašanja prema 6 dimenzija: lokus, stabilnost, globalnost, te namjeru, sebičnost i krivnju. Temeljem ovog instrumenta može se izračunati više rezultata 
(prema navedenim dimenzijama ili ukupni rezultat), ovisno o specifičnom cilju istraživanja. Za potrebe ovog istraživanja korištene su mjere za svih 6 dimenzija: lokus odnosno internalnost, stabilnost, globalnost, namjera, sebičnost i krivnja, koje se dobivaju zbrajanjem odgovarajućih čestica kroz 4 hipotetske situacije. U ovom istraživanju unutarnja konzistentnost pojedinih subskala Mjere atribucija u vezi izražena Cronbachovim alfa koeficijentom iznosila je $\alpha=.64$ za internalnost, $\alpha=.69$ za stabilnost, $\alpha=.7$ za globalnost, $\alpha=.66$ za namjeru, $\alpha=.75$ za sebičnost te $\alpha=.77$ za krivnju. Kako je riječ o instrumentu prevedenom za potrebe ovog istraživanja, očekivana latentna struktura je provjerena konfirmatornom faktorskom analizom. Iako je uobičajena faktorska analiza rezultirala jednofaktorskim rješenjem, provedena konfirmatorna faktorska analiza potvrdila je opravdanost korištenja zasebnih koeficijenata za svaku dimenziju. S obzirom na superiornost konfirmatorne faktorske analize za ovo pitanje, prednost će biti dana višefaktorskom rješenju. Više riječi o mjernim modelima Mjere atribucija u vezi bit će u potpoglavlju 4.2.1.

\section{Upitnik atribucijskog stila}

Upitnik atribucijskog stila (eng. Attributional Style Questionnaire, ASQ, Peterson, Semmel, Von Baeyer, Abramson, Metalsky, Seligman, 1982), temelji se na samoizvještajima sudionika koji ukazuju kojim uzrocima osoba pripisuje određene ishode u životu. Daje rezultat za eksplanatorni stil negativnih i pozitivnih događaja duž tri kauzalne dimenzije: internalni/eksternalni, stabilni/nestabilni, te globalni/specifični uzrok. ASQ se sastoji od opisa 12 hipotetskih situacija, pola pozitivnih (npr. Susrećete prijatelja i on hvali Vaš izgled.) a pola negativnih (npr. Već neko vrijeme bezuspješno pokušavate naći posao.), a zadatak sudionika je ocijeniti vjerojatni uzrok situacije duž tri kauzalne dimenzije, koristeći skalu sa 7 uporišnih točaka (npr. od 1-potpuno ovisi o drugim ljudima i okolnostima (eksternalan uzrok) do 7potpuno ovisi o meni (internalan uzrok)). Čestice instrumenta navedene su u Prilogu 9. Moguće je dobiti šest različitih ukupnih rezultata koji ukazuju na to u kojoj mjeri sudionik čini globalne, internalne i stabilne atribucije uzroka pozitivnih i negativnih događaja. Rezultati se dobivaju zbrajanjem odgovora na korespondentnim česticama (npr. za globalnost u raznim situacijama), zasebno za pozitivne i negativne događaje. Uz to, moguće je dobiti rezultate ukupnog kompozitnog pozitivnog i negativnog atribucijskog stila, ali i atribucijskog stila vezanog uz socijalne odnose ili postignuće (zasebnim zbrajanjem rezultata po pojedinim dimenzijama za situacije socijalnih odnosa i postignuća). No, kako smo temeljem provedenih konfirmatornih 
faktorskih analiza ${ }^{2}$ odlučili koristiti zasebne koeficijente za internalnost, stabilnost i globalnost (za sve opisane situacije zajedno), ispitana je pouzdanost tih subskala. Internalnost je pokazala Cronbachov alfa koeficijent od $\alpha=.54$, stabilnost $\alpha=.65$, te globalnost $\alpha=.75$.

\section{Zimbardov inventar vremenskih perspektiva}

Zimbardov inventar vremenskih perspektiva (Zimbardo i Boyd, 1999) sastoji se od 56 čestica (vidi Prilog 4), koje predstavljaju tvrdnje o vrijednostima, uvjerenjima i preferencijama pojedinaca. Inventar korišten u ovom istraživanju na hrvatski jezik preveli su Bunjevac, Bokulić, Matić, Punek, Tomaš i Vrlec (2009), te provjerili valjanost i pouzdanost na uzorku od 438 studenata Sveučilišta u Zagrebu. Sudionik izražava stupanj slaganja s pojedinom tvrdnjom na skali procjene s pet uporišnih točaka (1 - uopće se ne odnosi na mene, 3 - podjednako se odnosi i ne odnosi na mene, 5 - u potpunosti se odnosi na mene). Nakon rekodiranja obrnuto kodiranih čestica, uprosječe se odgovori na svim tvrdnjama koje čine pojedinu skalu vremenske perspektive. Moguće je dobiti rezultate na pet subskala, a petfaktorsku strukturu potvrđuje i provedena faktorska analiza.

Prva subskala je „,prošlost-negativna“, koja se sastoji od 10 čestica, a opisuje općenito negativan stav prema vlastitoj prošlosti (npr. „,Bolna iskustva iz prošlosti često se ponavljaju u mojim mislima"). Cronbachov alfa koeficijent ove subskale u glavnom istraživanju iznosio je $\alpha=.82$, a objašnjava $9.8 \%$ varijance. Drugi faktor, ,prošlost-pozitivna“, odražava pozitivan stav prema prošlosti. Sastoji se od 9 čestica i objašnjava 4,5\% ukupne varijance. Jedna od čestica ovog faktora je ,,Uživam u pričama o tome kako je bilo u 'dobra stara vremena'“. Cronbachov alfa koeficijent spomenute subskale je bio $\alpha=$.71. Treći faktor je faktor „sadašnjostihedonističke“, koji ukazuje na bezbrižan stav prema životu i usmjerenost na trenutne užitke, je faktor „sadašnjosti-hedonističke“. Neke od čestica zasićenih ovim faktorom su „Kad bih mogao, živio bih svaki dan kao da mi je posljednji“ i „Ponašam se impulzivno “, a objašnjava 8.9\% ukupne varijance, te ima Cronbachov alfa koeficijent od $\alpha=.82$. „Sadašnjost-fatalistička“ ukazuje na bespomoćnost i osjećaj nemoći u vezi kontroliranja svoje okoline. Čestica visoko zasićena ovim faktorom je npr. „Moj životni put kontroliraju sile na koje ne mogu utjecati“. Subskala sadašnjost-fatalistička imala Cronbachov alfa koeficijent $\alpha=.74$, sastoji se od 9

${ }^{2}$ Zbog uštede prostora, provedene konfirmatorne faktorske analize faktora koji nisu ušli u krajnji model nisu opisivane, no dostupne su na zahtjev. O mjernim modelima faktora uključenih u krajnji model bit će više riječi u poglavlju o rezultatima. 
čestica, te objašnjava 3.9\% ukupne varijance. Faktor „budućnost““ “ sastoji se od 13 čestica, te odražava usmjerenost na budućnost i veću sklonost planiranju, a primjer čestice zasićene ovim faktorom je ,Vjerujem da bi dan trebalo svakog jutra unaprijed isplanirati“. Imao je Cronbachov alfa koeficijent $\alpha=.81$, a objašnjava $6.3 \%$ ukupne varijance.

\section{$\underline{\text { Upitnik komunikacijskih obrazaca prilikom sukoba }}$}

Upitnik komunikacijskih obrazaca prilikom sukoba (eng. Communication patterns questionnaire, $C P Q$ ) autora Christensena i Sullawaya (1984) je podijeljen na 3 dijela koji ispituju ponašanja partnera u 3 faze sukoba - kad se pojavi neki problem u vezi (4 čestice, npr. „Kad se u vezi pojavi neki problem, oba partnera izbjegavaju raspravljati o problemu“), tijekom rasprave (18 čestica, npr. ,,Tijekom rasprave o problemu u vezi, žena vrši pritisak na muškarca da počne ili prestane nešto činiti dok se muškarac tomu odupire. ") i nakon rasprave o problemu u vezi (13 čestica, npr. ,Nakon rasprave o problemu u vezi, Muškarac traži podršku drugih osoba (roditelja, prijatelja, djece). “). Svaki dio se sastoji od simetričnih (npr. „Oba partnera izbjegavaju raspravljati o problemu“) i asimetričnih čestica (npr. „Muškarac pokušava započeti raspravu, dok žena pokušava izbjeći raspravu. "), a sudionici svaku česticu trebaju procijeniti na skali s 9 uporišnih točaka prema tome koliko često se navedeni obrazac interakcije javlja kad su suočeni s nekim problemom. Instrument sadrži 4 subskale: uzajamnu konstruktivnu komunikaciju, muško zahtijevanje uz žensko povlačenje, žensko zahtijevanje uz muško povlačenje, te uzajamno izbjegavanje i suzdržavanje. Ciljno ponašanje koje se željelo ispitati ovim istraživanjem jest obrazac konstruktivne komunikacije, te su stoga u daljnje analize uključene čestice samo te subskale. Kao što je ranije spomenuto, za potrebe ovog istraživanja konstruirana je Mjera namjere konstruktivne komunikacije prilikom sukoba, koja mjeri prediktore konstruktivne komunikacije prilikom sukoba (stav prema konstruktivnoj komunikaciji, socijalna norma konstruktivne komunikacije i percipirana bihevioralna kontrola, te namjera konstruktivne komunikacije u budućim sukobima). Kriterijsko ponašanje koje ovi prediktori predviđaju je konstruktivna komunikacija prilikom sukoba mjerena subskalom konstruktivne komunikacije Upitnika komunikacijskih obrazaca prilikom sukoba. Subskala konstruktivne komunikacije (eng. Communication patterns questionnaire, CPQ) autora Christensena i Sullawaya (1984) sadrži 7 čestica, a ukupni rezultat subskale konstruktivne komunikacije dobiva se tako da se od zbroja rezultata na česticama koja ukazuju na pozitivna ponašanja prilikom sukoba oduzima zbroj čestica koje ukazuju na negativna ponašanja u 
situaciji sukoba. U glavnom istraživanju utvrđena je pouzdanost za ovu subskalu od $\alpha=.73$. Provedena konfirmatorna fatorska analiza ukazuje na jednofaktorsko rješenje kojim je objašnjeno $35,45 \%$ varijance.

\section{Sociodemografski podaci}

Sudionici su odgovorili na deset pitanja koja su se odnosila na njihova sociodemografska obilježja. Među njima su: spol, dob, veličina mjesta boravka, veličina mjesta u kojem su proveli veći dio svog života, jesu li im oba roditelja živa, te ukoliko jesu li roditelji u braku, ukoliko su roditelji razvedeni koliko su godina imali u trenutku razvoda roditelja, jesu li u ozbiljnoj vezi, trajanje veze, te žive li s partnerom/icom. 


\section{REZULTATI}

\subsection{Preliminarne provjere $i$ analize podataka}

Kako bismo mogli provesti analize koje će pružiti odgovore na postavljene probleme, provedene su određene preliminarne analize i provjere podataka. Ove analize i provjere uključuju tretman podataka koji nedostaju u bazi, detekciju i tretman univarijatno ili multivarijatno odstupajućih podataka, analizu osnovnih deskriptivnih pokazatelja i matrice bivarijatnih korelacija kompozitnih varijabli, te faktorske analize.

\subsubsection{Analiza i tretman podataka koji nedostaju}

Analizom podataka koji nedostaju (tzv. missing value analysis) u bazi s odgovorima 240 sudionika zaključeno je da problem izostanka pojedinih odgovora nije zastupljen u značajnijoj mjeri, te da ne postoji sustavnost u obrascu nedostajućih odgovora. Postotak podataka koji nedostaju kreće se od nultog za većinu čestica, do maksimalnih $2.9 \%$ u slučaju jedne čestice Mjere atribucija u vezi (,Vaša djevojka se drži hladno i distancirano. Ponašanje moje djevojke je takvo zbog mene (npr. kakav sam tip osobe, moje trenutno raspoloženje)"). Moguće je da je riječ „distancirano“ uzrokovala porast nedostajućih odgovora za ovu česticu, budući da je značenje ove riječi moglo biti nepoznato dijelu sudionika.

Budući da je obrazac nedostajućih podataka slučajan (tzv. missing completly at random), kao tretman nedostajućih podataka odabrana je metoda procjene nedostajućih podataka. Naime, odbacivanjem sudionika kojima nedostaje neki podatak gubi se značajan dio podataka te se ta metoda ne preporučuje (Tabachnick i Fidell, 2013). Zamjena nedostajućeg podatka aritmetičkom sredinom, iako ne utječe na aritmetičku sredinu, može utjecati na parametre fit-a, no u našem istraživanju je nedostajućih podataka bilo ispod 2\% po pojedinoj varijabli. Upotrebom metode dostupne u programu SPSS (eng. Series mean), vrijednosti koje nedostaju zamijenjene su prosjekom odgovarajuće varijable na cijelom uzorku. Odabrana metoda imputacije vrijednosti ne utječe na aritmetičke sredine pojedinih varijabli, te njihovih kompozita, no rezultira smanjenjem standardne devijacije varijabli budući da povećava udio rezultata koji ne odstupaju od prosjeka. Odabrana metoda je primjerena, budući da su nedostajući podaci bili raspoređeni slučajno, te se sudionici s nedostajućim podacima na određenoj varijabli nisu značajno razlikovali od ostalih u odgovorima na drugim varijablama. Nakon što su formirane kompozitne varijable, temeljem podataka sa zamijenjenim nedostajućim vrijednostima, provjerena su univarijatna i multivarijatna odstupanja rezultata na kompozitnim varijablama. 


\subsubsection{Univarijatna i multivarijatna odstupanja rezultata}

Univarijatno odstupajući podaci (tzv. outliers) su slučajevi s neočekivanom vrijednošću na jednoj varijabli, dok su multivarijatna odstupanja slučajevi s neočekivanim ili neuobičajenim kombinacijama odgovora na više varijabli (Tabchnick i Fidell, 2013). Kako bismo utvrdili univarijatna odstupanja, generirana je tablica frekvencija $\mathrm{i} z$ vrijednosti rezultata na kompozitnim mjerama. Ustanovljeno je da nema univarijatnih odstupanja na većini mjera. $\mathrm{Na}$ onim mjerama na kojima ima, ustanovljeno je da riječ o odstupanjima dva sudionika $\mathrm{s}$ vrijednostima većim od 3,5 z na više od četiri mjere. Kako postojanje odstupanja na više mjera sugerira da je riječ zapravo o multivarijatnim odstupanjima, odlučeno je da će se prvo provesti analiza multivarijatnih odstupanja te time potvrditi jesu li spomenuta dva sudionika i multivarijatno odstupajuća.

Kao kriterij za provjeru postojanja multivarijatnih aberacija tj. odstupajućih kombinacija varijabli koje su u fokusu ovog istraživanja, izračunate su Mahalanobisove distance. Mahalanobisova distanca ukazuje na udaljenost vrijednosti pojedinog sudionika od centroida ostalih slučajeva, kada je centroid točka sjecišta središnjih vrijednosti svih varijabli u zamišljenom multivarijatnom prostoru (Tabachnick i Fidell, 2013). Uz kriterij $p<.001$ te $d f=$ 29 (broj varijabli za koje se vrši provjera), kritična vrijednost hi kvadrata u ovom istraživanju iznosi 58,301 (Tabachnick i Fidell, 2013). Uvidom u Mahalanobisove distance više od kritične vrijednosti zaključeno je da postoje četiri sudionika s multivarijatnim odstupanjima. Odstupanja ukazuju na statistički značajne razlike u izraženosti relevantnih varijabli kod ova četiri sudionika u odnosu na ostatak uzorka, a provedbom t- testova utvrđeno je da ova skupina sudionika partnerovo negativno ponašanje pripisuje više stabilnim $(t=2,476, p=, 014)$ i više sebičnim uzrocima $(t=2.016, p=, 045)$, izražava slabiju namjeru konstruktivne komunikacije u budućnosti $(t=-2,315, p=, 021)$, te izvještava o manje konstruktivne komunikacije u vlastitoj vezi u proteklih mjesec dana $(t=-4,437, p=, 000)$. Spomenuta četiri odstupajuća slučaja uključuju i dva sudionika kod kojih je uz multivarijatna odstupanja utvrđeno postojanje i univarijatnih odstupanja.

Prilikom isključivanja sudionika iz obrade temeljem Mahalanobisovih distanci postoji opasnost isključivanja sudionika koji čine neku specifičnu manju skupinu na koju nije moguće generalizirati rezultate istraživanje ili skupinu određenih specifičnih obilježja (Tabachnick i Fidell, 2013). Stoga su napravljene dodatne analize u vidu niza regresijskih jednadžbi kojima je provjereno koje varijable razlikuju 4 sudionika kod kojih su uočena multivarijatna odstupanja od ostatka uzorka. Nisu uočeni nikakvi sustavni obrasci razlikovnih varijabli za odstupajuće 
slučajeve, te je zaključeno da ih smijemo isključiti iz analize. Postojanje multivarijatnih odstupanja može prikriti postojanje drugih takvih rezultata (Tabachnick i Fidell, 2013), zbog čega smo nakon izbacivanja multivarijatno odstupajuća četiri slučaja cijeli postupak utvrđivanja odstupanja ponovili, čime je utvrđeno da više ne postoje Mahalanobisove distance iznad kritične vrijednosti hi kvadrata. Ukupan broj sudionika na kojima se provode daljnje analize stoga iznosi $N=236$.

\subsubsection{Deskriptivni rezultati i normalitet distribucija}

Prije provedbe analiza koje će ponuditi odgovore na postavljene istraživačke probleme, analizirani su deskriptivni pokazatelji kompozitnih varijabli korištenih u ovom istraživanju (Tablica 3). U Tablici 3 možemo uočiti da, u pogledu vremenskih perspektiva, kod sudionika dominiraju orijentacije na prošlost pozitivnu, sadašnjost hedonističku te budućnost, čiji su prosječni rezultati iznad središnje vrijednosti skale, a istovremeno su sudionici izražavali niže vrijednosti rezultata na subskalama prošlosti negativne i sadašnjosti fatalističke, s prosječnim vrijednostima ispod središnje vrijednosti skale. Ovakav prosječan profil očekivan je s obzirom na uzorak mlađih osoba, s relativno visokim udjelom studenata ili fakultetski obrazovanih osoba.

Pozitivan rezultat na internalnosti Mjere atribucija u vezi ukazuje da su sudionici skloniji pripisivati partnerov negativan postupak partneru i njegovim osobinama, nego što uzrok pronalaze u sebi. Uzrok partnerovog negativnog ponašanja ne smatraju stabilnim, već ga u većoj mjeri pripisuju trenutnim okolnostima, no istovremeno smatraju da je ono što je dovelo do partnerovog negativnog ponašanja prisutno i u drugim područjima njihove veze. Odgovori na pitanja smatraju li da je partner postupio namjerno loše, te treba li ga kriviti zbog njegovih postupaka su oko središnje vrijednosti skale, no u manjoj mjeri smatraju da je partner postupao iz sebičnih pobuda. Uočavamo prilično velika raspršenja rezultata subskale odgovornosti upitnika Mjere atribucija u vezi, što ukazuje na veću međusobnu razliku u odgovorima na ovim česticama među sudionicima, u odnosu na subskalu kauzalnosti.

Rezultati sudionika na tri dimenzije Upitnika atribucijskog stila (ASQ) su podjednaki, te se nalaze nešto iznad sredine teorijskog raspona ukupnih rezultata skale (12 do 84), što ukazuje na ponešto izraženiju sklonost sudionika ovog istraživanja pripisivanju uzroka događaja sebi, stabilnim uzrocima te percepcije da su uzroci globalne naravi. Podsjetimo, temeljem provedenih konfirmatornih faktorskih analiza odlučeno je da će biti korišteni indeksi 
stabilnosti, globalnosti i internalnosti formirani kao linearne kombinacije čestica za pojedinu dimenziju kroz svih 12 opisanih hipotetskih situacija.

Ukupni rezultati na skali konstruktivne komunikacije, mogu biti i negativni, budući da se ukupni rezultat formira oduzimanjem zbroja negativnih ponašanja od zbroja pozitivnih ponašanja. Stoga je teorijski ukupni raspon rezultata od -33 do 23. Dobiveni rezultati sugeriraju značajno prevladavanje pozitivne komunikacije u vezama sudionika uključenih u istraživanje, što je i očekivano s obzirom na uzorak mladih odraslih osoba koji kvalitetu svojih veza procjenjuju visokom.

Tablica 3. Aritmetičke sredine, standardne devijacije i mjere oblika distribucije kompozitnih varijabli $(N=236)$

\begin{tabular}{|c|c|c|c|c|c|}
\hline Instrument & & $M$ & $S D$ & $\begin{array}{c}\text { Asimetričnost } \\
\text { distribucije } \\
\text { (eng. }^{\text {engs }}\end{array}$ & $\begin{array}{c}\begin{array}{c}\text { Spljoštenost } \\
\text { distribucije } \\
\text { (eng. }\end{array} \\
\text { kurtosis) }^{\text {b }}\end{array}$ \\
\hline \multirow{6}{*}{$\begin{array}{c}\text { Zimbardov } \\
\text { inventar } \\
\text { vremenskih } \\
\text { perspektiva }\end{array}$} & Prošlost pozitivna & 3,54 & 0,039 &,- 351 &, 421 \\
\hline & Prošlost negativna & 2,64 & 0,046 &, 137 &,- 396 \\
\hline & Sadašnjost & 3,45 & 0,036 &,- 147 & ,495 \\
\hline & hedonistička & & & & \\
\hline & Sadašnjost fatalistička & 2,65 & 0,040 &, 124 &,- 318 \\
\hline & Budućnost & 3,47 & 0,038 &,- 459 & ,436 \\
\hline \multirow{6}{*}{$\begin{array}{c}\text { Mjera atribucija } \\
\text { u vezi }\end{array}$} & RAM internalnost & 1,41 & 0,271 & ,542 & ,650 \\
\hline & RAM'stabilnost & 11,01 & 0,231 & ,026 &,- 630 \\
\hline & RAMc globalnost & 14,85 & 0,278 &,- 437 &,- 053 \\
\hline & RAM namjera & 11,54 & 3,990 &, 152 &,- 404 \\
\hline & RAM sebičnost & 9,54 & 3,834 & ,360 &,- 444 \\
\hline & RAM krivnja & 10,52 & 4,253 & ,345 &,- 544 \\
\hline \multirow{3}{*}{$\begin{array}{c}\text { Upitnik } \\
\text { atribucijskog } \\
\text { stila }\end{array}$} & $\mathrm{ASQ}^{\mathrm{d}}$ internalnost & 42,25 & 5,370 &,- 082 & ,625 \\
\hline & ASQ stabilnost & 42,21 & 5,520 &,- 912 & 1,240 \\
\hline & ASQ globalnost & 42,40 & 5,390 &,- 930 & 1,676 \\
\hline $\begin{array}{c}\text { Upitnik } \\
\text { komunikacijskih } \\
\text { obrazaca }\end{array}$ & $\begin{array}{l}\text { Konstruktivna } \\
\text { komunikacija }\end{array}$ & 12,19 & 0,470 &,- 718 & ,081 \\
\hline
\end{tabular}

${ }^{\text {a }}$ Standardna pogreška mjere asimetričnosti distribucije iznosi , 158

b Standardna pogreška mjere spljoštenosti distribucije iznosi ,316 
Temeljem podataka o asimetričnosti i spljoštenosti distribucija iz Tablice 2., te uvidom u histograme distribucija kompozitnih varijabli, uočavamo da distribucije ne odstupaju značajno od normaliteta, odnosno ne odstupaju u mjeri koja bi utjecala na rezultate istraživanja. Kako ističu Tabachnick i Fidell (2013), formalni statistički testovi normaliteta distribucije ne bi trebali biti primaran izbor zbog njihove velike strogosti koja dovodi do odbacivanja nul hipoteze i u slučajevima vrlo malih odstupanja distribucije od normalne. S većim uzorcima važniji su veličina indeksa asimetričnosti i vizualni oblik distribucije nego razina statističke značajnosti. Također, u većim uzorcima odstupanje indeksa spljoštenosti distribucije od nule imaju zanemariv utjecaj na rezultate. Kako navodi Waternaux (1976, prema Tabachnick i Fidell, 2013), pozitivna ili negativna odstupanja u spljoštenosti distribucije dovode do podcjenjivanja varijance, no taj efekt pozitivne spljoštenosti nestaje s više o 100 sudionika, a efekt negativne spljoštenosti nestaje u uzorcima većim od 200. Slijedeći smjernice koje su postavili Gravetter i Wallnau (2014), te George i Mallery (2010), koje ističu kao prihvatljiv raspon vrijednosti asimetričnosti i spljoštenosti distribucije \pm 2 kako bismo distribuciju mogli smatrati normalnom, zaključujemo da su rezultati kompozitnih varijabli korištenih u ovom istraživanju normalno distribuirani.

\subsubsection{Bivarijatne povezanosti među kompozitnim varijablama}

Tablica 4 sadrži korelacije kompozitnih varijabli koje se koriste u daljnjim istraživanjima. Kako bismo provjerili oblik povezanosti, za varijable koje imaju ne-nulte povezanosti napravljeni su dijagrami raspršenja, koje ovdje nije moguće prikazati. Dijagrami raspršenja upućuje na linearne povezanosti. Kako bismo provjerili postojanje multikolinearnosti korišten je VIF pokazatelj (eng. variance inflation factor). Kako su svi VIF pokazatelji imali vrijednost ispod 2.5, a graničnom vrijednošću indikativnom za multikolineranost se smatra 3 (Field, 2013), zaključujemo kako ne postoji problem multikolinearnosti. U prilog tome govori i nepostojanje visokih koeficijenata korelacije $u$ Tablici 3. Problem singulariteta također nije prisutan, budući da kompoziti nisu formirani tako da uključuju druge kompozite ili njihove elemente. 
Tablica 4. Matrica bivarijatnih korelacija kompozitnih varijabli $(N=236)$

\begin{tabular}{|c|c|c|c|c|c|c|c|c|c|c|c|c|c|c|c|c|c|c|}
\hline & 1. & 2. & 3. & 4. & 5. & 6. & 7. & 8. & 9. & 10. & 11. & 12. & 13. & 14. & 15. & 16. & 17. & 18. \\
\hline 1. Prošlost negativna & 1 & & & & & & & & & & & & & & & & & \\
\hline 2. Prošlost pozitivna &,- 125 & 1 & & & & & & & & & & & & & & & & \\
\hline 3. Sad. hedonistička &, 104 &, $352^{* *}$ & 1 & & & & & & & & & & & & & & & \\
\hline 4. Sad. fatalistička &, $345 * *$ & ,075 &, $395 * *$ & 1 & & & & & & & & & & & & & & \\
\hline 5. Budućnost &,- 088 &, 070 &,$- 263 * *$ &,$- 298 * *$ & 1 & & & & & & & & & & & & & \\
\hline 6. RAM internalnost &,- 056 & ,080 &,- 003 &, 029 &, 031 & 1 & & & & & & & & & & & & \\
\hline 7. RAM stabilnost &, $130^{*}$ &,- 123 & ,016 &, $159 *$ &,$- 199 * *$ &, 062 & 1 & & & & & & & & & & & \\
\hline 8. RAM globalnost &, 054 &, 010 &, 054 & ,025 & ,000 &,$- 180 * *$ &, $306 * *$ & 1 & & & & & & & & & & \\
\hline 9. RAM namjera & ,092 &,- 086 &,- 003 & ,088 &,- 071 &,$- 172 * *$ &, $410^{* *}$ &, $471 * *$ & 1 & & & & & & & & & \\
\hline 10. RAM sebičnost &, 024 &,- 007 & 053 & ,091 &,- 091 &, 058 &, $447 * *$ &, $379 * *$ &, $649 * *$ & 1 & & & & & & & & \\
\hline 11. RAM krivnja &, 019 & ,108 &, 071 &, 111 & ,006 &, 029 &, $306 * *$ &, $429 * *$ &, $561 * *$ &, $656 * *$ & 1 & & & & & & & \\
\hline 12. ASQ internalnost & ,090 &,- 113 &,- 099 &, 045 &,- 060 &,- 117 &, $173^{* *}$ &, $205 * *$ &, 117 & ,038 &, 072 & 1 & & & & & & \\
\hline 13. ASQ stabilnost &, $258^{* *}$ &,$- 226 * *$ &,- 061 &, $201 * *$ &,$- 184 * *$ &,- 080 &, $266^{* *}$ &, $181 * *$ &, $218^{* *}$ &, $241 * *$ &, $170 * *$ &, $488 * *$ & 1 & & & & & \\
\hline 14. ASQ globalnost &, $239 * *$ &,$- 171 * *$ &,- 033 & ,163* &,- 106 &,- 040 &, $180^{* *}$ &, $233 * *$ &, $136^{*}$ &, $253 * *$ &, 127 &, $458 * *$ &, $675^{* *}$ & 1 & & & & \\
\hline 15. TPP stav &,- 006 &, $170^{*}$ & ,103 &,- 065 &, $182^{*}$ &,- 012 &,$- 301 * *$ &,- 002 &,$- 131^{*}$ &,$- 248 * *$ &,- 125 &,- 088 &,- 128 &,- 043 & 1 & & & \\
\hline 16. TPP norma &, $185 * *$ &, $193 * *$ &, $149^{*}$ &, 041 & ,083 &,- 042 &,- 093 &, 024 &,- 034 &,- 052 & ,080 &,- 049 &,- 045 &, 012 &, $190 * *$ & 1 & & \\
\hline 17. TPP kontrola &, $281 * *$ & ,025 &, $206 * *$ &, $226 * *$ &,- 044 &,- 034 &, $129 *$ &, $231 * *$ & ,066 &, $178 * *$ &, $261 * *$ &, 019 &, $258^{* *}$ &, $254 * *$ &, 024 &, $195 * *$ & 1 & \\
\hline 18. TPP namjera &,- 105 &, $143^{*}$ & ,080 &, $207 * *$ &, $183 * *$ & ,019 &,$- 317 * *$ &,- 046 &,- 082 &,$- 175^{* *}$ &,- 110 &,$- 173 * *$ &,$- 256 * *$ &,$- 198 * *$ &, $559 * *$ &, $265 * *$ &, $161 * *$ & 1 \\
\hline $\begin{array}{l}\text { 19. Konstruktivna } \\
\text { komunikacija }\end{array}$ &,$- 195^{* *}$ &, $155^{*}$ &, 055 &,$- 175^{* *}$ &, $186 * *$ &, 052 &,$- 307 * *$ &,$- 204 * *$ &,$- 330 * *$ &,$- 328 * *$ &,$- 303 * *$ &,- 113 &,$- 285 * *$ &,$- 228 * *$ &, $271 * *$ &, $139 *$ &, $224 * *$ & ,436** \\
\hline
\end{tabular}

$* * p<.01, * p<.05$

RAM - Mjera atribucija u vezi (eng. Relationship attribution measure)

ASQ - Upitnim atribucijskog stila (eng. Atribution style questionnaire)

TPP - Upitnik Teorije planiranog ponašanja 
Prvi problem propituje jesu li stav prema ponašanju, subjektivna norme i percipirana bihevioralna kontrola pozitivno povezani s namjerom za konstruktivno rješavanje sukoba $\mathrm{i}$ konstruktivnim rješavanjem sukoba. Elementi postulirani Teorijom planiranog ponašanja (stav, percipirana norma, te bihevioralna kontrola) pozitivno umjereno koreliraju s namjerom konstruktivne komunikacije, što je i očekivano. Kao najsnažnija pojedinačna odrednica namjere ističe se stav prema ponašanju $(r=, 566, p<0,01)$. Stav je ujedno prediktivan za percipiranu normu, s kojom nisko pozitivno korelira $(\mathrm{r}=, 190, \mathrm{p}<0,01)$, no nije povezan $\mathrm{s}$ percipiranom bihevioralnom kontrolom $(\mathrm{r}=, 024)$. Percipirana norma i percipirana bihevioralna kontrola su u pozitivnoj niskoj korelaciji $(\mathrm{r}=, 195, \mathrm{p}<0,01)$, što je u skladu s postavkama Teorije planiranog ponašanja, jer ukazuje da osobe koje u višoj mjeri smatraju da se konstruktivna komunikacija od njih očekuje, drže i da se uistinu mogu prilikom sukoba ponašati konstruktivno ako to žele. Svi elementi Teorije planiranog ponašanja pozitivno koreliraju s kriterijskom varijablom konstruktivne komunikacije prilikom sukoba, što potvrđuje postavljenu hipotezu. Rezultati potvrđuju i drugu hipotezu, budući da je namjera konstruktivne komunikacije prilikom budućih sukoba pozitivno povezana sa stvarnom konstruktivnom komunikacijom prilikom sukoba u sljedećih mjesec dana $(r=, 436, \mathrm{p}<0,01)$.

Svrha provedene korelacijske analize ujedno je bilo definiranje potencijalnih odrednica konstruktivne komunikacije. Kako je definirano problemom 6, glavni problem ovog istraživanja propituje povećavaju li neke od odrednica (vremenske perspektive, atribucijski stil, te atribucijski stil specifičan za domenu) prediktivnost modela postuliranog Teorijom planiranog ponašanja za konstruktivno komunikaciju prilikom sukoba u bliskim vezama. Iz Tablice 4. je vidljivo da dimenzije vremenske perspektive koreliraju s kriterijskom varijablom konstruktivne komunikacije, ali i elementima teorije planiranog ponašanja (stav, percipirana norma, percipirana bihevioralna kontrola i namjera), a čime se bavio treći istraživački problem. Za kriterijsku varijablu najsnažnijim korelatom se pokazala dimenzija prošlosti negativne ( $r=$ -,195, p < 0,01). Stav pozitivo korelira s prošlošću pozitivnom $(r=, 170, \mathrm{p}<0,05)$ i budućnošću $(r=, 182, \mathrm{p}<0,05)$, no ne i hedonističkom sadašnjošću $(r=, 103$, n.s.). Subjektivna norma je povezana s prošlošću pozitivnom $(r=, 185, \mathrm{p}<0,01)$ i negativnom $(r=, 193, \mathrm{p}<0,01)$ te sadašnjošću hedonističkom $(r=, 149, \mathrm{p}<0,05)$, dok percipirana bihevioralna kontrola negativno korelira s prošlošću negativnom $(r=-, 281, \mathrm{p}<0,01)$, sadašnjošću hedonističkom $(r$ $=-, 206, \mathrm{p}<0,01)$ te sadašnjošću fatalističkom $(r=-, 226, \mathrm{p}<0,01)$. Valja napomenuti da je riječ o niskim korelacijama. Iako su uočeni neki očekivani obrasci, određene povezanosti nisu bile pretpostavljene hipotezama 3a, 3b i 3c, pa možemo zaključiti da su hipoteze djelomično potvrđene. Dimenzije vremenskih perspektiva očekivano međusobno koreliraju, iako 
iznenađuje nalaz da prošlost negativna korelira isključivo sa sadašnjošću fatalističkom ( $r=$ ,345, p < 0,01). Primjerice, Huić, Krznarić i Kamenov (2018) su utvrdile korelacije prošlosti negativne sa svim ostalim dimenzijama vremenskih perspektiva izuzev sadašnjosti fatalističke. Uvidom u Tablicu 4, možemo vidjeti da je riječ o koeficijentima korelacije dimenzije prošlosti negativne i ostalih vremenskih perspektiva (izuzev budućnosti) koje bi s većim uzrokom sudionika vjerojatno prešle prag statističke značajnosti, pa je moguće da su utvrđene neznačajne korelacije posljedica nešto manjeg broja sudionika.

Četvrti problem propitivao je povezanost atribucijskog stila i percipirane bihevioralne kontrole. Očekivano, dimenzije generalnog atribucijskog stila ne koreliraju s odrednicama Teorije planiranog ponašanja, izuzev u slučaju percipirane bihevioralne kontrole koja pozitivno korelira s mjerama stabilnosti $(r=, 258, \mathrm{p}<0,01)$ i globalnosti $(r=, 254, \mathrm{p}<0,01)$. Kako je umjerena korelacija korespondentnih dimenzija atribucijskih mjera specifičnih za domenu i mjera općenitog atribucijskog stila očekivana, korelacije utvrđene s kontrolom treba podrobnije ispitati, kako bi se isključila mogućnost da je riječ o artefaktu uzrokovanom korelacijama istih dimenzija na ASQ i RAM. O tome će više riječi biti u nastavku. Stabilnost i globalnost ujedno negativno nisko koreliraju $\mathrm{s}$ konstruktivnom komunikacijom. Internalnost, stabilnost i globalnost su međusobno u umjerenim pozitivnim korelacijama.

Peti problem bavio se pitanjem povezanosti stila atribuiranja partnerovog negativnog ponašanja i konstruktivnog rješavanja sukoba. Atribucijski stil specifičan za domenu, odnosno rezultati na dimenzijama Mjere atribucija u vezi koreliraju s odrednicama Teorije planiranog ponašanja, te konstruktivnom komunikacijom. Osobe koje pozitivnije atribuiraju ponašanje partnera u intimnoj vezi bit će sklonije konstruktivnom rješavanju sukoba, dok će sklonost negativnom atribuiranju ponašanja partnera biti povezana $s$ destruktivnim ponašanjima prilikom sukoba. Osobe koje partnerovo negativno ponašanje pripisuju uzrocima stabilnim u vremenu $(r=-, 307, \mathrm{p}<0,01)$, smatraju da je riječ o uzrocima koji se odražavaju u različitim domenama veze $(r=-, 204, \mathrm{p}<0,01)$, te koji partnerovim postupcima pripisuju zlu namjeru ( $\mathrm{r}$ $=-, 330, \mathrm{p}<0,01)$ i sebične pobude $(r=-, 328, \mathrm{p}<0,01)$, te smatraju da partnera treba kriviti zbog njegovih postupaka $(r=-, 303, p<0,01)$ izvještavaju o manje konstruktivne komunikacije prilikom sukoba u vezi. Možemo zaključiti da je time peta hipoteza potvrđena.

Stabilnost $(r=-, 301, \mathrm{p}<0,01)$, zla namjera $(r=-, 131, \mathrm{p}<0,01)$ i sebičnost $(r=-, 248$, $\mathrm{p}<0,01)$ pripisana uzroku partnerova negativnog ponašanja povezani su s negativnim stavom prema konstruktivnoj komunikaciji prilikom sukoba. Atribucije partnerova negativnog ponašanja nisu korelirale $\mathrm{s}$ normom konstruktivne komunikacije. U kojoj mjeri sudionici partnerovo negativno ponašanje pripisuju stabilnim uzrocima $(r=-, 129, \mathrm{p}<0,05)$, prisutnim u 
drugim domenama veze $(r=-, 231, \mathrm{p}<0,01)$, te koliko partnerov postupak pripisuju sebičnim uzrocima $(r=-, 178, \mathrm{p}<0,01)$ i pripisuju mu krivnju $(r=-, 261, \mathrm{p}<0,01)$ korelira negativno $\mathrm{s}$ percipiranom bihevioralnom kontrolom nad ponašanjem konstruktivne komunikacije prilikom sukoba. Sve dimenzije Mjere atribucija u vezi, izuzev internalnosti, negativno nisko koreliraju s konstruktivnom komunikacijom. Dimenzije Mjere atribucija u vezi umjereno pozitivno međusobno koreliraju, izuzev internalnosti koja nije povezana s pripisivanjem partnerovog negativnog ponašanja sebičnim uzrocima, te okrivljavanjem partnera za negativne postupke.

U prethodnom smo koraku provjerili prediktivni potencijal svake pojedine odrednice konstruktivne komunikacije, međutim na temelju provedenih obrada ne možemo znati koliki je ukupni prediktivni potencijal grupe odrednica za pojedini element Teorije planiranog ponašanja ili samu konstruktivnu komunikaciju. S obzirom na to da su odrednice unutar iste grupe međusobno korelirane (npr. dimenzije atribucija u vezi) te da se njihovi prediktivni doprinosi preklapaju, provedene su kompletne regresijske analize na svakoj grupi odrednica zasebno za stav, percipiranu normu, percipiranu bihevioralnu kontrolu, namjeru ponašanja, te konstruktivnu komunikaciju. U Tablici 5. nalaze se rezultati kompletnih regresijskih analiza u kojima su prediktori bili dimenzije vremenskih perspektiva, atribucija u vezi, te općih atribucija. 
Tablica 5. Rezultati kompletne regresijske analize prediktora za pojedine elemente Teorije planiranog ponašanja, te konstruktivnu komunikaciju kao kriterije $(\mathrm{N}=236)$.

\begin{tabular}{|c|c|c|c|c|c|}
\hline & Stav & Norma & Kontrola & Namjera & Kon. kom. \\
\hline Prediktor & $\beta$ & $\beta$ & $\beta$ & $\beta$ & $\beta$ \\
\hline 1. Prošlost negativna & ,031 &, $226^{* *}$ &, $193 * *$ & ,009 &,- 099 \\
\hline 2. Prošlost pozitivna & , 108 &, $156^{*}$ &,- 014 &, 050 & ,067 \\
\hline 3. Sad. hedonistička & , 129 & 105 &, $154 *$ &, $161 *$ & , 123 \\
\hline 4. Sad. fatalistička &,- 059 &,- 065 &, 054 &,$- 189 * *$ &,- 085 \\
\hline 5. Budućnost &, $137 *$ & 072 &, 055 & ,095 & , 127 \\
\hline 6. RAM internalnost &, 043 &,- 047 &,- 045 & ,068 & 034 \\
\hline 7. RAM stabilnost &,$- 218 * *$ &,- 057 &, 026 &,$- 252 * *$ &,- 108 \\
\hline 8. RAM globalnost & ,111 &,- 001 &, $167 *$ & ,059 &,- 010 \\
\hline 9. RAM namjera & ,119 &,- 026 &,$- 240 * *$ & , 165 &,- 089 \\
\hline 10. RAM sebičnost &,$- 274 * *$ &,- 127 & ,017 &,- 120 &,- 067 \\
\hline 11. RAM krivnja &,- 015 & , 177 &, $253 * *$ &,- 051 &,- 160 \\
\hline 12. ASQ internalnost &,- 081 &,- 049 &,$- 157 *$ &,- 065 &, 042 \\
\hline 13. ASQ stabilnost &,- 023 &,- 050 &, $183^{*}$ &,- 076 &,- 088 \\
\hline 14. ASQ globalnost &, 119 & 084 &, 106 &,- 016 &,- 049 \\
\hline $\mathbf{R}^{2}$ &, 184 &, 125 & ,264 & ,201 & 243 \\
\hline \multicolumn{6}{|c|}{$* p<0,05, * * p<0,01 ; \beta$ beta - ponder; $\mathrm{R}^{2}$ koeficijent multiple korelacije } \\
\hline \multicolumn{6}{|c|}{ RAM - Mjera atribucija u vezi (eng. Relationship attribution measure) } \\
\hline \multicolumn{6}{|c|}{ ASQ - Upitnim atribucijskog stila (eng. Atribution style questionnaire) } \\
\hline
\end{tabular}

Usporedbom Tablica 4. i 5. uočavamo da su neki prediktori koji su bivarijatno korelirali s kriterijima rezultirali neznačajnim $\beta$ ponderima, što je posljedica međusobnih korelacija određenih prediktora. Kako prema Teoriji planiranog ponašanja namjera proizlazi iz stava, percipirane norme i percipirane bihevioralne kontrole, moguće je da prediktori namjere navedeni u Tablici 4. nemaju direktan efekt na namjeru, već posredstvom stava, percipirane norme i percipirane bihevioralne kontrole. Iako ćemo ovu pretpostavku provjeriti strukturalnim modeliranjem, u svrhu definiranja strukturalnog modela, provedena je hijerarhijska regresijska analiza u kojoj su u prvom koraku dodani prediktori iz Tablice 4., a u drugom stav, percipirana norma i percipirana bihevioralna kontrola. U prvom koraku je objašnjeno 20.1\% varijance namjere konstruktivne komunikacije prilikom sukoba, a u drugom koraku je postotak objašnjene varijance porastao na $44,2 \%$, te su oba koraka bila značajna. Stav $(\beta=, 471, \mathrm{p}<$ $0,01)$, percipirana norma $(\beta=, 198, \mathrm{p}<0,01)$ i percipirana bihevioralna kontrola $\left(\beta=, 157^{* *}\right)$ pokazali su se značajnim prediktorima u drugom koraku, a značajni prediktor iz prvog koraka 
sadašnjost hedonistička je postao statistički neznačajan $(\beta=, 104$, n.s.). Preostala dva značajna prediktora iz prvog koraka, sadašnjost fatalistička $(\beta=-, 140, \mathrm{p}<0,05)$ i RAM stabilnost $(\beta=-$ ,134, p < 0,01), u drugom koraku su zadržala značajnu prediktivnost, iako je došlo do smanjenja $\beta$ pondera, što sugerira postojanje djelomične medijacije putem stava, percipirane norme te percipirane bihevioralne kontrole. Konstruktivan komunikacija prilikom sukoba u bliskim vezama nije imala značajnih prediktora u regresijskom modelu koji je uključivao dimenzije vremenskih perspektiva, općih atribucija i atribucija u vezi.

U nastavku će biti provjereno pristajanje podacima modela prediktora konstruktivne komunikacije postuliranog Teorijom planiranog ponašanja, te ukoliko će model biti zadovoljavajući, bit će proširen značajnim prediktorima stava, percipirane norme, percipirane bihevioralne kontrole te namjere ponašanja utvrđenih provedenim regresijskim analizama.

\subsection{Provjera modela teorije planiranog ponašanja za predviđanje konstruktivne} komunikacije prilikom sukoba metodologijom strukturalnog modeliranja

Kako bismo provjerili model Teorije planiranog ponašanja u kontekstu konstruktivne komunikacije prilikom sukoba, korištena je metoda strukturalnog modeliranja (engl. structural -equation modeling, SEM), koja omogućuje testiranje strukturalnog modela, uključujući međusobne kauzalne odnose, između latentnih varijabli konfirmatornim pristupom (Bentler, 1988). Metodologija strukturalnog modeliranja procjenjuje pristajanje predloženog modela stvarnim podacima istovremenim testiranjem niza strukturalnih ( $\mathrm{tj}$. regresijskih) jednadžbi koje opisuju odnose između varijabli pretpostavljenih modelom. Obrade strukturalnog modeliranja provedene su u računalnom programu IBM SPSS Amos.21, pri čemu su parametri procjenjivani metodom najveće vjerojatnosti (engl. maximum likelihood).

\subsubsection{Mjerni model}

Kako bismo neki model mogli provjeriti strukturalnim modeliranjem, prvo moramo uspostaviti mjerne modele svih njegovih latentnih varijabli (Byrne, 2001). To činimo provedbom konfirmatorne faktorske analize kojom se provjeravaju saturacije manifestnih varijabli ili indikatora latentnom varijablom. Mjerni model koji odgovara podacima pretpostavka je testiranja punog modela koji uključuje i odnose među latentnim varijablama. Definiranjem mjernog modela određuju se indikatori svakog konstrukta koji će biti korišteni u daljnjim obradama, te se definiraju čestice pomoću kojih će se formirati indikatori (Byrne, 
2001). Povećanjem broja indikatora smanjuje se vjerojatnost pristajanja modela podacima (Anderson i Gerbing, 1984; Williams i Holahan, 1994; Ding i sur., 1995), te povećava se potreban broj sudionika u istraživanju (Bollen, 1989). Stoga je uputno da se ograniči broj indikatora po latentnoj varijabli, no da ne bude manji od tri ili četiri (Bollen, 1989). Broj manifestnih varijabli po latentnoj varijabli smanjen je tehnikom parceliranja ${ }^{3}$ (eng. parceling). Takve združene čestice ili paketići (engl. item parcels) redovito imaju i bolje psihometrijske karakteristike od pojedinačnih čestica (Hall, Snell i Singer Foust, 1999). Paketići naspram čestica redovito imaju višu pouzdanost, više komunalitete, te viši omjer zajedničke naspram jedinstvene faktorske varijance, a smanjena je i vjerojatnost većih odstupanja u distribucijama (Little, Cunningham, Shahar i Widaman, 2002). Iako postoji više načina kako se mogu formirati paketići, Monte Carlo simulacije i druga metodološka istraživanja daju prednost planiranom naspram slučajnom združivanju. Planirano združivanje trebalo bi se provoditi kombinirajući čestice koje dijele neki sekundarni faktor u isti paketić, čime nemodelirani utjecaj postataje unikvitet indikatora, što izolira faktorska zasićenja i strukturalne procjene od kontaminiranja sekundarnim faktorom (Hall i sur., 1999). Stoga je za potrebe ovog istraživanja parceliranje provedeno prema postupku koji opisuju Little, Cunningham, Shahar i Widaman (2002) i koji uzima u obzir veličine saturacija pojedinih manifestnih varijabli konstruktom. Paketići su formirani jednostavnom linearnom kombinacijom čestica sličnog sadržaja i ujednačenih saturacija konstruktom.

U nastavku će biti opisano formiranje paketića za pojedine elemente modela prema Teoriji planiranog ponašanja (Slika 2). Prema modelu, stav je umnožak korespondentnih čestica bihevioralnih vjerovanja i subjektivne vrijednosti očekivanog ishoda (npr. Konstruktivno rješavanje sukoba omogućit će da partner/ica i ja imamo kvalitetniju vezu (uopće nije vjerojatno do vrlo vjerojatno) pomnoženo s Imati kvalitetniju vezu s partnerom/icom za mene bi bilo (iznimno loše do iznimno dobro)). Subjektivna norma je umnožak normativnog vjerovanja i motivacije za ponašanje u skladu s očekivanjima, dok percipiranu bihevioralnu kontrolu predstavlja umnožak kontrolnih vjerovanja i percipirane snage kontrolnih faktora. Stoga su formirani umnošci korespondentnih čestica za svaku subskalu upitnika, te su izračunate pouzdanosti novoformiranih čestica i njihove korelacije $\mathrm{s}$ ukupnim rezultatom (Prilog 7b). Latentne varijabla stava, norme, percipirane bihevioralne kontrole i namjere definirane su pomoću čestica ukoliko je četiri ili manje indikatora, ili paketića ukoliko je više

\footnotetext{
${ }^{3} \mathrm{U}$ nedostatku adekvatnijeg prijevoda, kao hrvatski naziv ove tehnike u radu se koristi parceliranje, dok se produkti parceliranja (eng. parcels) nazivaju paketićima.
} 
čestica. Čestice koje formiraju putem umnožaka i paketića pojedinu latentnu varijablu modela mogu se vidjeti u Prilogu 7c. U Tablici 5. možemo naći i dobivene indekse pristajanja podacima za svaki mjerni model: hi-kvadrat test $\left(\chi^{2}\right)$, vrijednost hi-kvadrat testa podijeljenu pripadajućim stupnjevima slobode $\left(\chi^{2 / d f)}\right.$, indeks najboljeg pristajanja $(G F I)$, indeks komparativnog pristajanja $(C F I)$ te prosječnu standardnu rezidualnu pogrešku (RMSEA).

Tablica 6. Struktura mjernih modela svih latentnih varijabli testiranih u strukturalnom modelu te njihovi indeksi pristajanja podacima $(N=236)$.

\begin{tabular}{|c|c|c|c|c|c|c|c|}
\hline \multirow[b]{2}{*}{ Latentna varijabla } & \multirow[b]{2}{*}{$\begin{array}{c}\text { Broj } \\
\text { indikatora }\end{array}$} & \multirow[b]{2}{*}{ Vrsta indikatora } & \multicolumn{5}{|c|}{ Indeksi pristajanja mjernih modela } \\
\hline & & & $\begin{array}{c}\chi^{2} \\
(\mathrm{df})^{4}\end{array}$ & $\chi^{2} / \mathrm{df}$ & GFI $^{5}$ & $\mathrm{CFI}^{6}$ & RMSEA $^{7}$ \\
\hline Stav & 3 & $\begin{array}{l}\text { paketići umnožaka } \\
\text { korespondentnih } \\
\text { čestica }\end{array}$ & $\begin{array}{c}, 694 \\
(1)\end{array}$ & ,694 & ,998 & 1,000 & 000 \\
\hline Percipirana norma & 3 & $\begin{array}{l}\text { paketići umnožaka } \\
\text { korespondentnih } \\
\text { čestica }\end{array}$ & $\begin{array}{c}, 671 \\
(1)\end{array}$ &, 671 & ,998 & 1,000 & ,000 \\
\hline $\begin{array}{l}\text { Percipirana } \\
\text { bihevioralna kontrola }\end{array}$ & 3 & $\begin{array}{l}\text { paketići umnožaka } \\
\text { korespondentnih } \\
\text { čestica }\end{array}$ & $\begin{array}{c}, 383 \\
(1)\end{array}$ & ,383 & ,999 & 1,000 & ,000 \\
\hline Namjera & 3 & čestice & $\begin{array}{l}, 118 \\
(1)\end{array}$ & ,118 & 1,000 & 1,000 & ,000 \\
\hline
\end{tabular}

Napomena: U testiranim mjernim modelima dopustili smo postojanje korelacija između parova pogrešaka čestica skala koje su nam sugerirali modifikacijski indeksi, a koje su bile sadržajno opravdane; $\mathrm{p}<0,05 ; \chi 2$ hi-kvadrat test; df broj stupnjeva slobode; GFI indeks najboljeg pristajanja (eng. goodness of fit index); CFI indeks komparativnog pristajanja (eng. comparative fit index); RMSEA prosječna standardna rezidualna pogreška (eng. root mean square error of approximation)

Provedene konfirmatorne faktorske analize pokazuju značajnost manifestnih varijabli kao indikatora latentnih varijabli, a u skladu s preporukama Byrne (2001), nakon što su provjereni mjerni modeli svake latentne varijable zasebno, mjerni modeli teorijski povezanih konstrukata testirani su zajedno. Iako je najčešće korišteni indeks pristajanja hi-kvadrat test, on je gotovo uvijek značajan za modele testirane na velikom uzorku $(N>200)$ (Brown, 2006.), pa se danas najčešće koristi uz korekciju s obzirom na broj stupnjeva slobode. Vrijednosti ovog indikatora koje ukazuju na pristajanje modela podacima su $\chi 2 / d f \leq 5$ (Jackson i sur., 1993; Marsh i Hocevar, 1985), a iz Tablice 5. je vidljivo da svi naši mjerni modeli udovoljavaju ovom kriteriju. Sljedeći korišteni indeks pristajanja je prosječna standardna rezidualna pogreška

\footnotetext{
${ }^{4}$ neznačajan $\chi^{2}$ ukazuje na pristajanje modela podacima

${ }^{5}$ manji ili jednak od 1 ; vrijednost 1 ukazuje na savršeno pristajanje

${ }^{6}$ varira u rasponu od 0 do 1 , a što je vrijednost bliža 1 , to je bolje pristajanje

7 vrijednost ispod,05 predstavlja odlično pristajanje podacima, vrijednost ispod,08 prihvatljivo pristajanje (Browne i Cudeck, 1993)
} 
(root-mean-square-residual, RMSEA) koja je za sve je modele bila jednaka vrijednosti 0,000, što upućuje na izvrsno pristajanje modela podacima. Indeks najboljeg pristajanja (goodness-offit indeks, GFI) i indeks komparativnog pristajanja (comparative-fit-indeks, $C F I$ ) odnose se na ukupnu količinu objašnjene varijance te se kreću u intervalu između vrijednosti 0 i 1, pri čemu vrijednosti bliže 1 ukazuju na bolje pristajanje modela. Kako svi modeli imaju ove vrijednosti više od ili jednake 0,998 , konfirmatorna faktorska analiza potvrdila je jednodimenzionalnost svih mjernih modela (Cole, 1987; Nunnally i Bernstein, 1994), pa mogu biti korišteni u ovom obliku u strukturalnom modelu odrednica konstruktivne komunikacije prilikom sukoba.

\subsubsection{Strukturalni model}

Nakon uspostave mjernih modela latentnih varijabli, testiran je strukturalni model teorije planiranog ponašanja za predviđanje konstruktivne komunikacije prilikom sukoba. Prema teorijskom modelu, značajne odrednice namjere konstruktivne komunikacije su stav o konstruktivnoj komunikaciji, percipirana norma te percipirana bihevioralna kontrola vezana uz konstruktivnu komunikaciju. Namjera je direktan prediktor samog ponašanja konstruktivne komunikacije prilikom sukoba. Specificiran je prvi strukturalni model (Slika 4) kod kojeg varijable stava, percipirane norme, te bihevioralne kontrole na konstruktivnu komunikaciju prilikom sukoba djeluju isključivo neizravno, preko namjere konstruktivne komunikacije. Oslobođene su usmjerene veze (regresijski koeficijenti) između svih prediktorskih varijabli (stav, percipirana norma, te bihevioralna kontrola), namjere te konačno konstruktivne komunikacije prilikom sukoba. Ovaj model raspolaže s 91 nezavisnom informacijom ${ }^{8}$. Prilikom skaliranja latentnih varijabli, saturacija manifestne varijable koja ima najvišu saturaciju latentnom varijablom fiksirana je na vrijednost 1 . Ovim modelom procjenjuju se 32 parametara. Ovakvom specifikacijom modela dobiva se identificirani (eng. overidentified) model sa 59 stupnjeva slobode, budući da broj ulaznih podataka premašuje broj parametara koje je potrebno procijeniti. Pokazatelji slaganja prvog modela su $\chi^{2}=91.214, p=0.005 ; \chi^{2} / d f=1.546 ; G F I=$ 0.946; $C F I=0.976 ; R M S E A=0.048$ (90\% interval pouzdanosti [0.027, 0.067]). Iako je ovim modelom objašnjeno $21.6 \%$ varijance konstruktivne komunikacije prilikom sukoba, te $56.7 \%$ varijance namjere konstruktivne komunikacije, te su se svi prediktori pokazali značajnima, indeksi pristajanja ukazuju na nešto slabije slaganje modela s podacima. Kako bismo dobili

\footnotetext{
${ }^{8}$ Izračunato prema formuli $[p \times(p+1)] / 2$ gdje je $p$ broj opaženih varijabli ili paketića koji se unose u analizu (Tabachnick i Fidell, 2013)
} 
model koji bolje pristaje podacima, testirani model prilagođavali smo temeljem modifikacijskih indeksa, koji nam daju procjene u kojoj će mjeri ukupna $\chi^{2}$ vrijednost pasti ako se određeni fiksirani parametar u modelu „oslobodi“ (Byrne, 2001), npr. ako se dopusti postojanje korelacije između dvije varijable modela. Takve izmjene su napravljene samo ukoliko su bile i teorijski opravdane, pa je tako u sljedećem koraku dopuštena i direktna veza percipirane bihevioralne kontrole na konstruktivnu komunikaciju prilikom sukoba. Drugi i konačni strukturalni model prikazan je na Slici 5. 


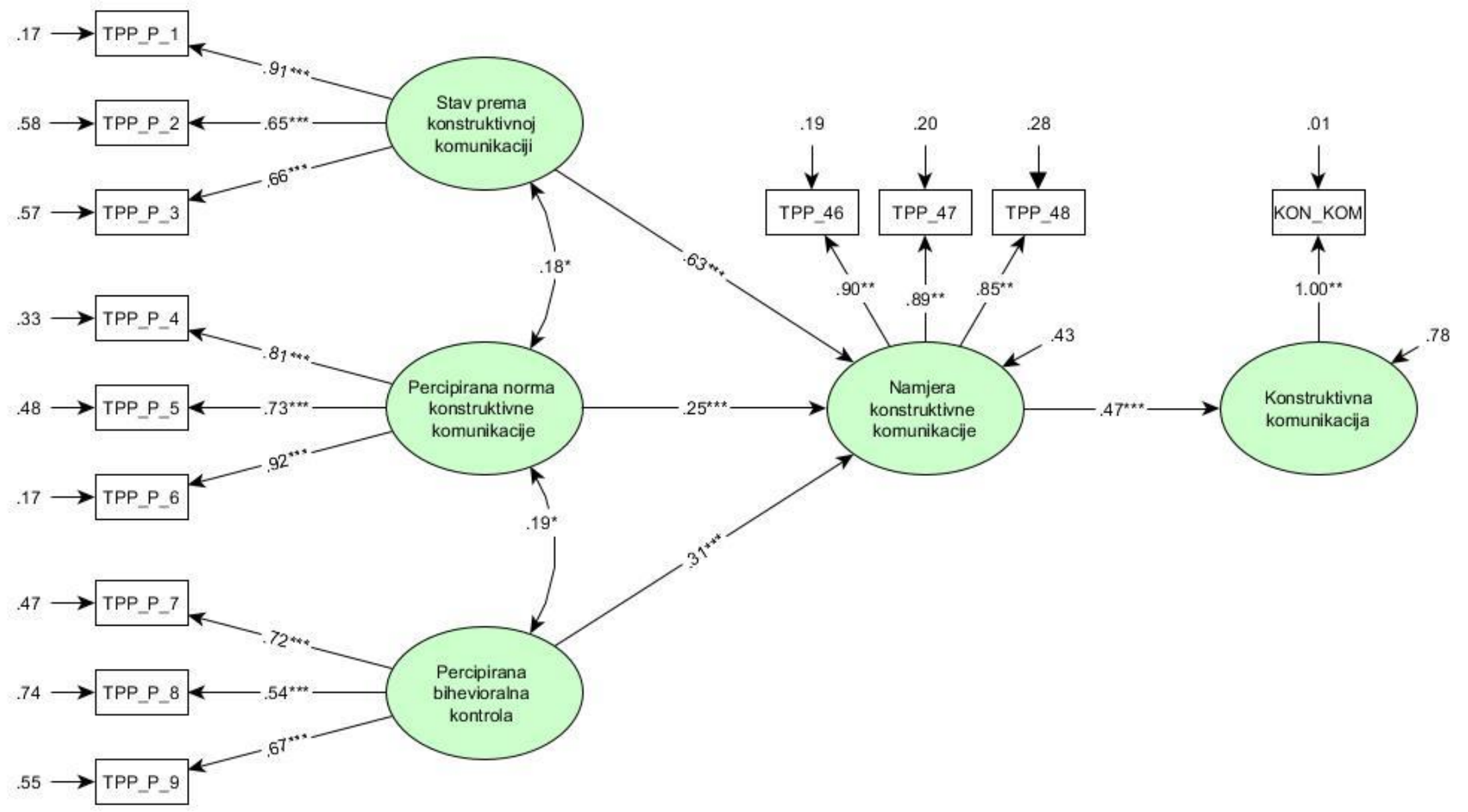

Slika 4. Strukturalni model odnosa elemenata Teorije planiranog ponašanja pri predikciji konstruktivne komunikacije prilikom sukoba $(N=236)$. Parametri su standardizirani, procijenjeni ML metodom. $* \mathrm{p}<0.05, * * \mathrm{p}<0.01, * * * \mathrm{p}<0.000$ 


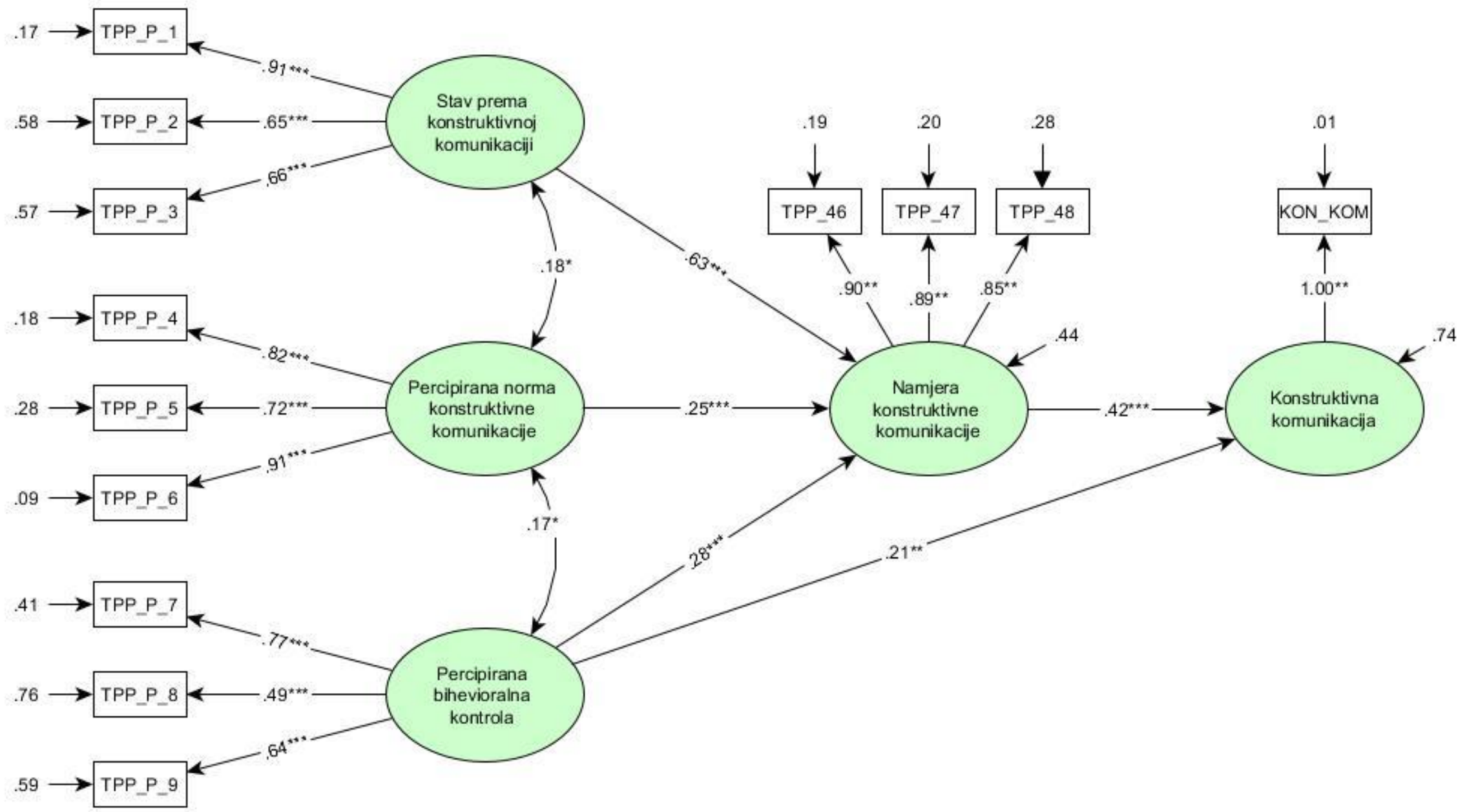

Slika 5. Konačni strukturalni model odnosa elemenata Teorije planiranog ponašanja pri predikciji konstruktivne komunikacije prilikom sukoba $(N=236)$. Parametri su standardizirani, procijenjeni ML metodom. ${ }^{*} \mathrm{p}<0.05,{ }^{* *} \mathrm{p}<0.01,{ }^{* * *} \mathrm{p}<0.000$ 
Modificirani model je također imao 91 nezavisnu informaciju, a njime su procijenjena 34 parametra, što je rezultiralo s 57 stupnjeva slobode. Ovako specificirani model imao je mnogo bolje indekse pristajanja od prethodnog modela: $\chi^{2}=71.510, p=0.094 ; \chi 2 / d f=1.254$; $G F I=0.956 ; C F I=0.989 ; R M S E A=0.033(90 \%$ interval pouzdanosti $[0.000,0.055])$. Nizak i neznačajan rezultat hi kvadrat testa dobiven za ovaj model ukazuje na to da se empirijska matrica ne razlikuje od procijenjene populacijske matrice kovarijanci. Omjer vrijednosti $\chi^{2} \mathrm{i}$ stupnjeva slobode ispod je granične vrijednosti 2 (Ullman, 2013), što ukazuje na vrlo dobro slaganje s podacima. $C F I$ indeks je visoko iznad granice od 0.90 koja upućuje na prihvatljivo slaganje modela (Hu i Bentler, 1995). I vrijednost RMSEA indeksa upućuje na dobro pristajanje modela podacima, budući da se nalazi ispod vrijednosti od 0.05 koja upućuje na vrlo dobro slaganje modela s podacima (Browne i Cudeck, 1993). Relevantni pokazatelji slaganja ukazuju na to da revidirani model postavljen prema Teoriji planiranog ponašanja dobro opisuje empirijske podatke. U odnosu na prvi model, u kojem ne postoji direktan veza percipirane bihevioralne kontrole na komunikaciju prilikom sukoba u bliskim vezama, drugi model gdje ta veza postoji bolje reprezentira podatke (Tablica 7). Naime, razlika $\chi^{2}$ testa od 19.704, uz 2 stupnja slobode, ukazuje na postojanje statistički značajne razlike u smjeru boljeg pristajanja drugog modela podacima, na razini $p<0.01^{9}$. Kako je ujedno riječ o ugniježđenim modelima, odnosno do prvog modela možemo doći polazeći od modificiranog modela i postavljajući ograničenja modela (eng. constraints), ova dva modela možemo direktno uspoređivati. Stoga, u svrhu međusobne usporedbe modela, među indekse pristajanja uključen je i indeks koji se odnosi na parsimoničnost u procjeni pristajanja modelu - konzistentni Akaikeov kriterij informacije (engl. consistent Akaike's information criterion, CAIC). Ovaj indeks odnosi se na razmjer $\mathrm{u}$ kojem će se procjena parametara na originalnom uzorku replicirati u budućim uzorcima, pri čemu njegova manja vrijednost upućuje na bolje pristajanje modela podacima (Byrne, 2001). CAIC indeks potvrđuje bolje pristajanje podacima modificiranog modela koji sadržava direktnu vezu percipirane bihevioralne kontrole na konstruktivnu komunikaciju prilikom sukoba.

U konačnom modelu varijable stava, percipirane norme i bihevioralne kontrole objasnile su 55.8\% varijance namjere konstruktivne komunikacije, te uz namjeru kao odrednice konstruktivne komunikacije prilikom sukoba su objasnile $25.7 \%$ varijance tog kriterija. Rezultati dobiveni metodologijom strukturalnog modeliranja koje uključuje latentne varijable

\footnotetext{
${ }^{9}$ Uz kriterij $p<.001$ i $d f=2$, kritična vrijednost hi kvadrata iznosi 13.816 (Tabachnick i Fidell, 2013).
} 
(Slika 5) pokazuju da se na aktualnom uzorku stav pokazao najznačajnijim prediktorom namjere konstruktivne komunikacije $(\beta=0.63, p<0.01)$, slijedi percipirana bihevioralna kontrola $(\beta=0.28, p<0.01)$, dok je percipirana norma najslabiji prediktor namjere $(\beta=0.25$, $p<0.01)$. Istovremeno, percipirana norma slabo je korelirala s ostala dva prediktora $(r=.18, p$ $<0.05$, te $r=.17, p<0.05$ ), no stav i percipirana bihevioralna kontrola nisu međusobno korelirali ( $r=0.04, n . s$.). Namjera značajno predviđa konstruktivnu komunikaciju prilikom sukoba $(\beta=0.42, p<0.01)$, a značajnim direktnim prediktorom se pokazala i percipirana bihevioralna kontrola $(\beta=0.21, p<0.01)$. Procijenjeni su parametri ukupnih, izravnih i neizravnih (medijacijskih) efekata, a prikazani su u Tablici 8.

Tablica 7. Indeksi pristajanja za testirane strukturalne modele odrednica konstruktivne komunikacije prilikom sukoba u bliskim vezama $(N=236)$.

\begin{tabular}{|c|c|c|c|c|c|c|}
\hline \multirow[t]{2}{*}{ Model } & \multicolumn{6}{|c|}{ Indeksi pristajanja modela podacima } \\
\hline & $\chi^{2}(\mathbf{d f})^{10}$ & $\chi^{2} / \mathbf{d f}^{11}$ & GFI $^{12}$ & CFI $^{13}$ & RMSEA $^{14}$ & $\mathrm{CAIC}^{15}$ \\
\hline $\begin{array}{lllr}\text { Početni strukturalni } & \text { model } & \text { odrednica } \\
\text { komunikacije prilikom } & \text { sukoba } & \text { u bliskim } \\
\text { vezama postuliranih } & \text { Teorijom } & \text { planiranog } \\
\text { ponašanja (Slika 4) } & & \end{array}$ & $\begin{array}{c}91.214^{* *} \\
(59)\end{array}$ & 1.546 & .946 & .976 & .048 & 298.056 \\
\hline $\begin{array}{l}\text { Modificirani strukturalni model odrednica } \\
\text { komunikacije prilikom sukoba u bliskim } \\
\text { vezama postuliranih Teorijom planiranog } \\
\text { ponašanja (Slika 5) }\end{array}$ & $\begin{array}{c}71.510 \\
(57)\end{array}$ & 1.254 & .956 & .989 & .033 & 291.280 \\
\hline
\end{tabular}

Kao što Teorija planiranog ponašanja i predviđa, nema izravnog efekta stava prema ponašanju i percipirane norme ponašanja na samo ponašanje, već je efekt posredovan putem namjere. $\mathrm{S}$ druge strane, percipirana bihevioralna kontrola djeluje izravno, ali dijelom $\mathrm{i}$ posredstvom namjere na konstruktivnu komunikaciju prilikom sukoba. Sumativno, namjera je medijator efekta stava, percipirane norme te percipirane bihevioralne kontrole na komunikaciju prilikom sukoba u bliskim vezama.

\footnotetext{
${ }^{10}$ neznačajan $\chi^{2}$ ukazuje na pristajanje modela podacima

${ }^{11} \chi^{2} /$ df omjer manji od 2 smatra se vrlo dobrim pristajanjem modela podacima

12 manji ili jednak od 1; vrijednost 1 ukazuje na savršeno pristajanje

${ }^{13}$ varira u rasponu od 0 do 1 , a što je vrijednost bliža 1 , to je bolje pristajanje

14 vrijednost ispod ,05 predstavlja odlično pristajanje podacima, vrijednost ispod ,08 prihvatljivo pristajanje (Browne i Cudeck, 1993)

${ }^{15}$ omogućuje usporedbu modela, niža vrijednost sugerira bolje pristajanje podacima
} 
Tablica 8. Procijenjeni parametri ukupnih, izravnih i neizravnih (medijacijskih) efekata pri istraživanju povezanosti elemenata Teorije planiranog ponašanja i konstruktivne komunikacije prilikom sukoba kao kriterija, preko namjere konstruktivne komunikacije kao medijatora. Parametri su standardizirani, dobiveni $M L$ metodom u okviru modeliranja s latentnim varijablama $(N=236)$.

\begin{tabular}{lccc}
\hline Prediktor & Ukupni efekt & Izravni efekt & Neizravni efekt \\
\hline Stav prema konstruktivnoj komunikaciji & $.265^{* *}$ & .000 & $.266^{* *}$ \\
Percipirana norma konstruktivne komunikacije & $.104^{* *}$ & .000 & $.104^{* *}$ \\
Percipirana bihevioralna kontrola & $.325^{* *}$ & $.209^{* *}$ & $.118^{* *}$ \\
\hline$* * p<.01 ; * p<.05$ & & &
\end{tabular}

\subsection{Proširenje modela teorije planiranog ponašanja dimenzijama atribucija i vremenskih perspektiva}

Kako bismo odgovorili na šesti istraživački problem, doprinose li vremenska perspektiva i atribucijski stil, uz elemente koje postulira Teorija planiranog ponašanja (stav prema ponašanju, subjektivna norma te percipirana bihevioralna kontrola) boljem predviđanju ponašanja osoba prilikom sukoba, u model ćemo uvrstiti prediktore identificirane provedenim regresijskim jednadžbama (vidi Tablicu 4). Prije specificiranja takvog proširenog modela, potrebno je utvrditi mjerne modele svakog pojedinog prediktora provedbom konfirmatorne faktorske analize. Kao što je bio slučaj i s prethodno testiranim mjernim modelima, broj indikatora smanjen je tehnikom parceliranja, osim u slučaju Mjere atribucija u vezi koja je imala 4 čestice po dimenziji. Popis čestica koje su sačinjavale pojedini paketić nalaze se u prilozima 7c, 9b i 10b. Za pojedine prediktore ispitano je nekoliko mogućih modela, temeljenih na različitom formiranju paketića, a odabrani su oni modeli koji pristaju podacima ili su najbliže pristajanju podacima. Pristajanje mjernih modela latentnih prediktorskih varijabli podacima može se vidjeti u Tablici 8. Mjerni modeli svih prediktorskih varijabli pokazali su vrlo dobro pristajanje podacima, uz mjere pristajanja GFI iznad ,992, CFI od ,993 ili više, RMSEA ispod , 05 , te omjer $\chi^{2} / d f$ ispod 1,5 . 
Tablica 9. Struktura mjernih modela latentnih varijabli prediktora te njihovi indeksi pristajanja podacima $(N=236)$.

\begin{tabular}{lccccccc}
\hline \multicolumn{1}{c}{ Latentna varijabla } & Broj & Vrsta & \multicolumn{3}{c}{ Indeksi pristajanja mjernih modela } \\
& indikatora & indikatora & $\chi^{\mathbf{2}}(\mathbf{d f})^{\mathbf{1 6}}$ & $\chi^{\mathbf{2} / \mathbf{d f}^{\mathbf{1 7}}}$ & $\mathbf{G F I}^{\mathbf{1 8}}$ & $\mathbf{C F I}^{\mathbf{1 9}}$ & $\mathbf{R M S E A}^{\mathbf{2 0}}$ \\
\hline ZTPI prošlost negativna & 5 & paketići &, $713(2)$ &, 356 &, 999 & 1,000 &, 000 \\
ZTPI prošlost pozitivna & 3 & paketići &, $774(1)$ &, 774 &, 998 & 1,000 &, 000 \\
ZTPI sadašnjost & 5 & paketići & $4,983(4)$ & 1,246 &, 992 &, 998 &, 032 \\
hedonist. & & & & & & \\
ZTPI sadašnjost fatalist. & 3 & paketići &, $809(1)$ &, 809 &, 998 & 1,000 &, 000 \\
ZTPI budućnost & 4 & paketići & $1,026(1)$ & 1,026 &, 998 & 1,000 &, 011 \\
RAM stabilnost & 4 & čestice & $2,929(2)$ & 1,464 &, 994 &, 993 &, 044 \\
RAM globalnost & 4 & čestice & $1,143(2)$ & 0,571 &, 998 & 1,000 &, 000 \\
RAM namjera & 4 & čestice &, $921(2)$ &, 460 &, 998 & 1,000 &, 000 \\
RAM sebičnost & 4 & čestice &, $304(2)$ &, 152 &, 999 & 1,000 &, 000 \\
RAM krivnja & 4 & čestice & $1,591(2)$ &, 795 &, 997 & 1,000 &, 000 \\
ASQ stabilnost & 4 & paketići & $1,980(2)$ &, 990 &, 996 & 1,000 &, 000 \\
\hline
\end{tabular}

Napomena: U testiranim mjernim modelima dopustili smo postojanje korelacija između parova pogrešaka paketića koje su nam sugerirali modifikacijski indeksi, a koje su bile sadržajno opravdane; $\mathrm{p}<0,05 ; \chi^{2}$ hi-kvadrat test; df broj stupnjeva slobode; GFI indeks najboljeg pristajanja (eng. goodness of fit index); CFI indeks komparativnog pristajanja (eng. comparative fit index); RMSEA prosječna standardna rezidualna pogreška (eng. root mean square error of approximation)

ZTPI - Zimbardov upitnik vremenskih perspektiva (eng. Zimbardo time perspective inventory)

RAM - Mjera atribucija u vezi (eng. Relationship attribution measure)

ASQ - Upitnim atribucijskog stila (eng. Atribution style questionnaire)

S obzirom na zadovoljavajuće mjerne modele, specificiran je strukturalni model koji predstavlja proširenje modela Teorije planiranog modela. Riječ je o dva međusobno ugniježđena modela. Strukturalni model je specificiran vodeći se rezultatima regresijskih jednadžbi, no kako se rezultati dobiveni strukturalnim modeliranjem mogu ponešto razlikovati od rezultata regresijskih analiza, provjereno je postojanje veza svakog od prediktora s ostalim elementima modela, kao i postojanje direktnih veza s kriterijem konstruktivne komunikacije prilikom sukoba. Kako bismo dobili model koji prema svim indeksima pristajanja pristaje podacima, tako specificirani model postupno je prilagođavan vodeći se modifikacijskim indeksima ukoliko su sugerirane izmjene bile teorijski opravdane, te uklanjajući statistički neznačajne veze. Konkretno, dimenzije vremenskih perspektiva sadašnjost hedonistička i budućnost nisu se pokazale prediktivnima niti za jedan element postuliran Teorijom planiranog

\footnotetext{
16 neznačajan $\chi^{2}$ ukazuje na pristajanje modela podacima

${ }^{17} \chi^{2} / \mathrm{df}$ omjer manji od 2 smatra se vrlo dobrim pristajanjem modela podacima

${ }_{18}$ manji ili jednak od 1; vrijednost 1 ukazuje na savršeno pristajanje

${ }^{19}$ varira u rasponu od 0 do 1 , a što je vrijednost bliža 1 , to je bolje pristajanje

${ }^{20}$ vrijednost ispod ,05 predstavlja odlično pristajanje podacima, vrijednost ispod ,08 prihvatljivo pristajanje (Browne i Cudeck, 1993)
} 
ponašanja, niti za kriterij konstruktivne komunikacije prilikom sukoba. Nadalje, iako su regresijske jednadžbe sugerirale postojanje 5 prediktorski značajnih dimenzija Mjere atribucija u vezi (RAM), u kompletnom strukturalnom modelu samo su dimenzije sebičnosti i krivnje zadržale prediktivnu značajnost. Dimenzija stabilnosti općeg atribucijskog stila (ASQ) zadržana je u modelu, budući da je imala statistički značajnu regresijsku vezu s percipiranom bihevioralnom kontrolom. Opisane izmjene rezultirale su modelom na Slici 2, kojim su procijenjena 104 parametra, uz 562 stupnja slobode. Bez obzira na povoljan omjer broja ulaznih informacija i parametara za procjenu, budući da se radi o razmjerno kompleksnom modelu bilo je očekivano da bude donekle penaliziran kod onih pokazatelja slaganja koji uzimaju u obzir parsimoničnost (npr. RMSEA, prema Hooper, Coughlan i Mullen, 2008). Međutim, dobiveni indeksi pristajanja pokazali su se zadovoljavajućima: $\chi^{2}=795.439, p=0.000 ; \chi 2 / d f=1.41$; $G F I=0.848 ; C F I=0.921 ; R M S E A=0.042(90 \%$ interval pouzdanosti $[0.035,0.048])$. Modelom je objašnjeno 32,5\% kriterijske mjere konstruktivne komunikacije prilikom sukoba, te $57,2 \%$ namjere konstruktivne komunikacije.

Rezultati dobiveni metodologijom strukturalnog modeliranja koje uključuje latentne varijable (Slika 6) ukazuju na to da je na aktualnom uzorku varijabla stava prema konstruktivnoj komunikaciji najbolji prediktor namjere konstruktivne komunikacije prilikom sukoba $(\beta=.630$, $p<.01)$. Subjektivna norma konstruktivne komunikacije $(\beta=.251, p<.01)$ i percipirana bihevioralna kontrola $(\beta=.240, p<.01)$ pokazale su se podjednako snažnim prediktorima namjere konstruktivne komunikacije. Uz navedene elemente postulirane Teorijom planiranog ponašanja, namjeru je predviđala i vremenska perspektiva sadašnjosti fatalističke $(\beta=-.124, p$ $<.05)$. Namjera se pokazala najsnažnijim pojedinačnim prediktorom stvarne konstruktivne komunikacije $(\beta=.310, p<.01)$, uz dimenziju stabilnosti Mjere atribucija u vezi $(\beta=-.268, p$ $<.01)$, te percipiranu bihevioralnu kontrolu $(\beta=.211, p<.01)$ koja je uz neizravan efekt preko namjere imala i direktan efekt na konstruktivnu komunikaciju prilikom sukoba (procijenjeni parametri ukupnih, izravnih i neizravnih efekata prikazani su u Tablici 9.). Dimenzija stabilnosti Mjere atribucija u vezi pokazala se relativno snažnim statistički značajnim prediktorom stava o konstruktivnoj komunikaciji $(\beta=-.398, p<.01)$, objasnivši $15.8 \%$ varijance. Usmjerenost na prošlost, odnosno dimenzije vremenskih perspektiva prošlosti negativne $(\beta=.160, p<.05)$ i prošlosti pozitivne $(\beta=.320, p<.01)$ predviđaju subjektivnu normu konstruktivne komunikacije, pri čemu je prošlost pozitivna snažniji prediktor norme konstruktivne komunikacije. Ovim dvjema varijablama objašnjeno je $12.8 \%$ varijance subjektivne norme. Istovremeno, pokazalo se da ove dvije latentne varijable nisu u međusobnoj korelaciji, što je donekle neočekivano. Neočekivano je i nepostojanje statistički značajne 
korelacije između prošlosti negativne i sadašnjosti fatalističke. Međutim, prošlost pozitivna ( $r$ $=.570, p<.01)$ jest umjereno pozitivno korelirale sa sadašnjošću fatalističkom. Prediktorima percipirane bihevioralne kontrole pokazale su se dimenzija krivnje Mjere atribucija u vezi $(\beta=$ $-.290, p<.01)$ te dimenzija stabilnosti općeg atribucijskog stila $(\beta=-.240, p<.05)$, koje su zajedno objasnile $28.4 \%$ varijance percipirane bihevioralne kontrole. 


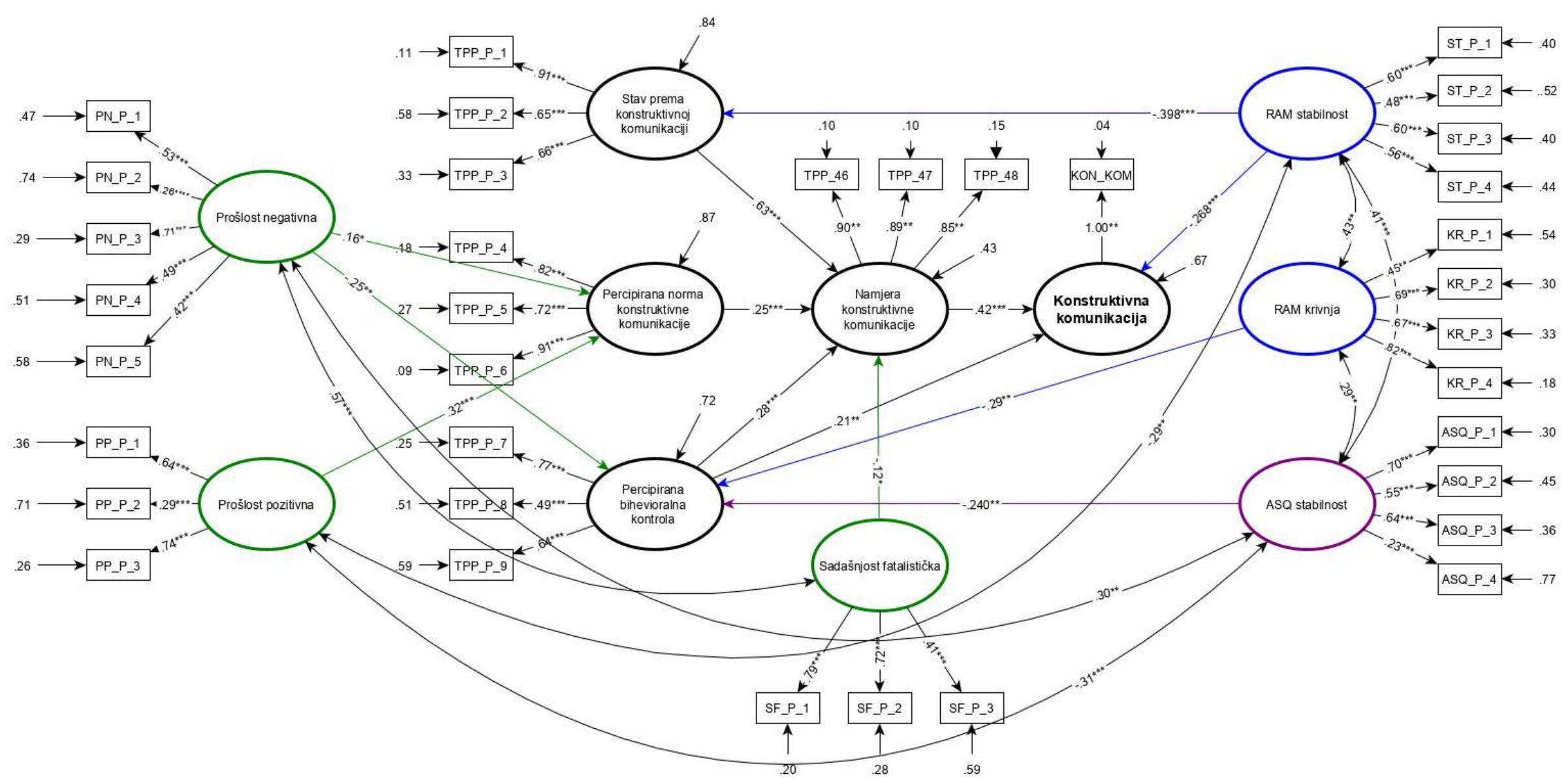

Slika 6. Strukturalni model odnosa elemenata Teorije planiranog ponašanja, vremenskih perspektiva i atribucija pri predikciji konstruktivne komunikacije prilikom sukoba $(N=236)$. Parametri su standardizirani, procijenjeni ML metodom. $* \mathrm{p}<0.05, * * \mathrm{p}<0.01, * * * \mathrm{p}<0.000$ 
Tablica 10. Procijenjeni parametri ukupnih, izravnih i neizravnih (medijacijskih) efekata u proširenom modelu Teorije planiranog ponašanja pri predviđanju konstruktivne komunikacije prilikom sukoba. Parametri su standardizirani, dobiveni $M L$ metodom u okviru modeliranja s latentnim varijablama $(N=$ 236).

\begin{tabular}{lccc}
\hline Prediktor & Ukupni efekt & Izravni efekt & Neizravni efekt \\
\hline Stav prema konstruktivnoj komunikaciji & $.190^{* *}$ & .000 & $.296^{* *}$ \\
Subjektivna norma konstruktivne komunikacije & $.076^{* *}$ & .000 & $.076^{* *}$ \\
Percipirana bihevioralna kontrola & $.283^{* *}$ & $.211^{* *}$ & $.072^{* *}$ \\
Prošlost negativna & $-.060^{* *}$ & .000 & $-.060^{* *}$ \\
Prošlost pozitivna & $.024 * *$ & .000 & $.024^{* *}$ \\
Sadašnjost fatalistička & $-.037 * *$ & .000 & $-.037^{* *}$ \\
RAM stabilnost & $-.344^{* *}$ & $-.268 * *$ & $-.076^{* *}$ \\
RAM krivnja & $-.082 * *$ & .000 & $-.082^{* *}$ \\
ASQ stabilnost & $-.068^{* *}$ & .000 & $-.068^{* *}$ \\
\hline$* * p<.01 * p<.05$ & & & \\
RAM - Mjera atribucija u vezi (eng. Relationship attribution measure) & & & \\
ASQ - Upitnim atribucijskog stila (eng. Atribution style questionnaire) & & &
\end{tabular}

Kako bismo odgovorili na šesti problem, potrebno je usporediti osnovni model koji je uključivao samo elemente postulirane Teorijom planiranog ponašanja i prošireni model koji je uz elemente postulirane Teorijom planiranog ponašanja uključivao i dimenzije atribucija, te vremenske perspektive (Tablica 11). Uspoređujući indekse pristajanja, vidljivo je da osnovni model nešto bolje pristaje podacima. Razlika $\chi 2$ iznosi 723.929, što uz 506 stupnjeva slobode predstavlja statistički značajnu razliku $\chi 2$, uz razinu rizika od $1 \%{ }^{21}$. Korigirani Akaikeov kriterij informacije također daje prednost osnovnom modelu. No, pritom valja imati na umu da svi navedeni indeksi snažno penaliziraju povećanje broja parametara, odnosno favoriziraju parsimoniju. Imajući na umu znatno veću složenost proširenog modela, što ujedno dovodi do povećanja broja parametara, očekivano je da indeksi pristajanja favoriziraju osnovni model. Međutim, unatoč povećanoj složenosti, prošireni model prema svim pokazateljima vrlo dobro pristaje podacima, a istovremeno objašnjava 6,8\% varijance kriterija konstruktivne komunikacije više nego osnovni model, što je povećanje postotka objašnjene varijance za 26,4\%. Stoga držimo da se pri analizi fenomena konstruktivne komunikacije prilikom sukoba svakako u obzir trebaju uzeti i saznanja dobivena proširenim modelom Teorije planiranog

${ }^{21}$ Uz kriterij $p<.001$ i $d f=500$, kritična vrijednost hi kvadrata iznosi 576.493 (Tabachnick i Fidell, 2013). 
ponašanja, budući da je prediktivnost dodatnih varijabli tolika da ju se ne može zanemariti, unatoč indeksima pristajanja koji nedvosmisleno favoriziraju prvi model.

Tablica 11. Usporedba osnovnog i proširenog modela odrednica konstruktivne komunikacije prilikom sukoba u bliskim vezama temeljem indeksa pristajanja i postotka objašnjene varijance kriterija $(N=236)$

\begin{tabular}{|c|c|c|c|c|c|c|c|}
\hline \multirow[t]{2}{*}{ Model } & \multicolumn{6}{|c|}{ Indeksi pristajanja modela podacima } & \multirow{2}{*}{$\begin{array}{l}\text { \% objašnjene } \\
\text { varijance } \\
\text { kriterija }\end{array}$} \\
\hline & $\chi^{2}(\mathrm{df})^{22}$ & $\chi^{2} / \mathbf{d f}^{23}$ & GFI $^{24}$ & CFI $^{25}$ & RMSEA $^{26}$ & $\mathrm{CAIC}^{27}$ & \\
\hline $\begin{array}{lr}\text { Osnovni } & \text { strukturalni } \\
\text { model } & \text { odrednica } \\
\text { komunikacije } & \text { prilikom } \\
\text { sukoba (Slika 5) } & \end{array}$ & $71.510(57)$ & 1.254 & .956 & .989 & .033 & 291.280 & 25.7 \\
\hline $\begin{array}{lr}\begin{array}{l}\text { Prošireni } \\
\text { model }\end{array} & \text { strukturalni } \\
\text { odrednica } \\
\text { komunikacije } & \text { prilikom } \\
\text { sukoba (Slika 6) }\end{array}$ & $\begin{array}{c}795.439 * * \\
(563)\end{array}$ & 1.41 & .848 & .921 & .042 & 1461.214 & 32.5 \\
\hline
\end{tabular}

${ }^{22}$ neznačajan $\chi^{2}$ ukazuje na pristajanje modela podacima

${ }^{23} \chi^{2}$ dff omjer manji od 2 smatra se vrlo dobrim pristajanjem modela podacima

${ }^{24}$ manji ili jednak od 1; vrijednost 1 ukazuje na savršeno pristajanje

${ }^{25}$ varira u rasponu od 0 do 1 , a što je vrijednost bliža 1 , to je bolje pristajanje

26 vrijednost ispod ,05 predstavlja odlično pristajanje podacima, vrijednost ispod ,08 prihvatljivo pristajanje (Browne i Cudeck, 1993)

${ }^{27}$ omogućuje usporedbu modela, niža vrijednost sugerira bolje pristajanje podacima 


\section{RASPRAVA}

Cilj ovog istraživanja bio je ispitati ulogu kognitivnih i motivacijskih odrednica konstruktivne komunikacije pri rješavanju sukoba u intimnim vezama. Specifičnije, zanimalo nas je može li se konstruktivna komunikacija prilikom sukoba u intimnim vezama predvidjeti temeljem modela Teorije planiranog ponašanja, proširenog konstruktima vremenskih perspektiva i atribucijskog stila. U skladu s postavljenim istraživačkim problemima, u ovom su radu ispitani relativni doprinosi elemenata Teorije planiranog ponašanja, odnosno stava prema ponašanju, subjektivne norme i percipirane bihevioralne kontrole objašnjenju namjere za konstruktivno rješavanje sukoba, kao i objašnjenju samog ciljnog ponašanja - konstruktivnog rješavanja sukoba. Ispitane su interkorelacije svih elemenata Teorije planiranog ponašanja, kao i povezanost namjere ponašanja i stvarnog ponašanja. Konstruiran je prediktivni model konstruktivne komunikacije prilikom sukoba koji uključuje sve elemente Teorije planiranog ponašanja. Početni model zatim je proširen varijablama vremenskih perspektiva, atribucijskog stila te stila atribuiranja partnerovog negativnog ponašanja. Dobiveni rezultati bit će komentirani u nastavku.

\subsection{Učinci stava, subjektivne norme i percipirane bihevioralne kontrole na namjeru konstruktivne komunikacije prilikom sukoba u intimnoj vezi}

Teorija planiranog ponašanja postavlja dvije medijacijske pretpostavke. Prvo, efekt stava i subjektivne norme na ponašanje je u potpunosti posredovan namjerom, dok je efekt percipirane bihevioralne kontrole djelomično posredovan namjerom ponašanja. Drugo, efekti svih bioloških, socijalnih, okolinskih, kulturoloških i drugih utjecaja su posredovani elementima Teorije planiranog ponašanja te nemaju izravan utjecaj na namjeru ponašanja $i$ samo ponašanje (Sutton, 2002). Stoga smo, sukladno prvoj i drugoj postavljenoj hipotezi, očekivali da će pozitivan stav prema konstruktivnom rješavanju sukoba, izraženija subjektivna norma konstruktivne komunikacije, te viša percipirana bihevioralna kontrola biti pozitivno povezani s namjerom konstruktivne komunikacije, te posljedično i sa samim ponašanjem konstruktivne komunikacije prilikom sukoba. Rezultati analiza provedenih u okviru prvog problema, te strukturalnog modeliranja Teorije planiranog ponašanja (Slika 5), potvrdili su ovu pretpostavku. Varijable stava, subjektivne norme i percipirane bihevioralne kontrole objasnile su 55.8\% varijance namjere konstruktivne komunikacije. Testirajući osnovni strukturalni model odrednica komunikacije prilikom sukoba (Slika 5) utvrđeno je da su varijable stava, subjektivne 
norme i percipirane bihevioralne kontrole posredno, preko namjere kao odrednice konstruktivne komunikacije prilikom sukoba, objasnile $25.7 \%$ varijance konstruktivne komunikacije prilikom sukoba. Postotak objašnjene varijance namjere konstruktivne komunikacije značajno je viši od prosječnog postotka objašnjene varijance $(37 \%) \mathrm{u}$ istraživanjima Teorije planiranog ponašanja, a koju su svojom meta-analizom utvrdili Armitage i Conner (2001) na uzorku od 185 studija. Ajzen (1991) ističe da stavovi, subjektivna norma i percipirana bihevioralna kontrola imaju varijabilne efekte na namjeru ovisno o različitim ponašanjima i situacijama. Stoga, iako sva tri elementa imaju učinak na namjeru, u određenim situacijama neki od konstrukata može imati veću prediktivnu vrijednost od drugih.

U našem istraživanju najsnažniji prediktor namjere ponašanja je stav prema konstruktivnoj komunikaciji, što je u skladu s Ajzenovim i Fishbeinovim (2005) viđenjem Teorije planiranog ponašanja. Stav je dugi niz godina smatran jedinim relevantnim prediktorom ponašanja, o čemu je više riječi bilo u uvodu. Prediktivnost stava za određeno ponašanje povećana je ispitivanjem stava o specifičnom ponašanju te mjerenjem istog tog ponašanja. Kao što ističe Ajzen (1991), da bi stavovi bili visoko prediktivni za ponašanje, posredstvom namjere ponašanja, mora se ispitivati stav o konkretnom ponašanju, a ne o stav o širokom setu sličnih ponašanja. Ovaj uvjet je u našem istraživanju bio zadovoljen, što objašnjava visoku prediktivnost stava. Ako pogledamo čestice formirane za ispitivanje elemenata Teorije planiranog ponašanja (Prilog 7a), primjećujemo da je stav prema konstruktivnoj komunikaciji ispitan dvojako. Osim direktnih mjera stava, mjera stava je formirana i umnošcima bihevioralnih vjerovanja i korespondentnih subjektivnih vrijednosti ishoda. Kao što možemo vidjeti iz Priloga 7c, u strukturalni model Teorije planiranog ponašanja uključene su samo mjere stava formirane umnošcima, budući da direktne mjere stava nisu pokazale zadovoljavajuće pristajanje podacima. Iako se mora uzeti u obzir mogućnost da direktne mjere stava možda nisu dobro odabrane, izglednije je da je jednostavno riječ o superiornosti mjera stava nastalih kombiniranjem čestica bihevioralnih vjerovanja i subjektivnih vrijednosti ishoda. Takve mjere omogućuju razlikovanje vjerovanja o posljedicama konstruktivne komunikacije (npr. „,Konstruktivno rješavanje sukoba omogućit će da partner/ica i ja imamo kvalitetniju vezu. ") te pripisivanja vrijednosti takvom ishodu (npr. ,,Imati kvalitetniju vezu s partnerom/icom za mene bi bilo iznimno loše/iznimno dobro. "). Takvo mjerenje stava pruža potpuniji uvid u sadržaj stava, ali i antecedente stava. Deskriptivni podaci za čestice bihevioralnih vjerovanja ukazuju da visoko pozitivna uvjerenja o konstruktivnoj komunikaciji, budući da su aritmetičke sredine spomenutih čestica bile iznad 5, većinom čak iznad 6, uz skalu sa sedam uporišnih točaka. Međutim, ako pobliže pogledamo korespondentne čestice subjektivnih vrijednosti 
ishoda, uočit ćemo da u slučaju nekih parova čestica bihevioralno vjerovanje je visoko procijenjeno, ali je subjektivna vrijednost ishoda procijenjena znatno nižom, ili obrnuto. Takvi rezultati pružaju dodatan argument superiornosti ovakvog načina ispitivanja stavova. Naime, na primjeru čestice „Konstruktivno rješavanje sukoba unaprijedit će našu vezu. “ kao mjere bihevioralnog vjerovanja, možemo primijetiti da su sudionici u odnosu na rezultate ostalih čestica izrazili nešto niže slaganje s ovom tvrdnjom $(M=5.92, S D=.45)$, no unaprjeđenju veze su pripisali visoku subjektivnu vrijednost ishoda $(M=6.70, S D=.64)$. Nekorištenjem ovakvog načina mjerenja stava ne bismo bili u mogućnosti uočiti ovakve specifičnosti koje pružaju bolji uvid $\mathrm{u}$ razloge konstruktivne komunikacije prilikom sukoba, što otvara i kvalitetnije mogućnosti intervencije u terapiji parova. U Hrvatskoj je do sada provedeno relativno malo istraživanja koja su provjeravala postavke Teorije planiranog ponašanja, a u području bliskih odnosa nije ih bilo. Ona istraživanja koja jesu provjeravala Teoriju planiranog ponašanja, koristila su direktne mjere stava, subjektivne norme i percipirane bihevioralne kontrole, zanemarujući Ajzenove (2011) smjernice, čime je propuštena mogućnost adekvatnog zahvaćanja kompleksnog konstrukta kao što je stav o konkretnom ponašanju. Potvrđujući superiornost ovakvog načina ispitivanja stava o ponašanju, ovim istraživanjem pružena je mogućnost za daljnja istraživanja optimalnih načina mjerenja specifičnih stavova.

Subjektivna norma konstruktivne komunikacije te percipirana bihevioralna kontrola nad tim ponašanjem pokazale su se podjednako snažnim prediktorima namjere konstruktivne komunikacije prilikom sukoba. Prethodna istraživanja na mlađoj populaciji utvrdila su da subjektivna norma ima mnogo manji doprinos objašnjenju namjere nego stavovi i percipirana bihevioralna kontrola (Hagger i sur., 2002; Rivis i Sheeran, 2003). Podjednaka važnost subjektivne norme i percipirane bihevioralne kontrole dobivena u našem istraživanju može se objasniti specifičnostima vezanim uz ciljno ponašanje. Naime, komunikacija prilikom sukoba nije u potpunosti jednostrana, te se bazira na principu akcije i reakcije. Stoga je moguće da su naši sudionici (ispravno) percipirali da konstruktivna komunikacija prilikom sukoba u vezi nije sasvim pod njihovom voljnom kontrolom, kao što su to možda neka druga ponašanja. Osim utjecaja partnera na komunikaciju, sudionici su možda zaključili i da je situacija sukoba u vezi visoko emotivna situacija, pa su pretpostavili da bi njihove emocije mogle djelovati na izvođenje ponašanja, smanjujući njihovu percepciju bihevioralne kontrole. S druge strane, Hagger i sur. (2007) govore o razlikama između individualističkih i kolektivističkih kultura, utvrdivši veću važnost subjektivne norme u predviđanju namjere ponašanja u kolektivističkim kulturama nego individualističkim. Ovdje valja istaknuti da su Hagger i sur. (2007) kolektivističkim kulturama smatrali istočnoeuropske zemlje, odnosno tranzicijske zemlje, u 
koje po svim karakteristikama spada i Hrvatska. Iako je koncept individualizma i kolektivizma u svojem izvornom obliku donekle zastario, moguće je da su Hagger i sur. (2007) svojim istraživanjem individualizma i kolektivizma zapravo zahvatili koncept tradicionalnosti društva. Krasnner i sur. (2017) su proučavajući sjevernoameričke, južnoameričke, azijske kulture te kulture bivšeg europskog istočnog bloka utvrdili da nije sasvim opravdano zemlje bivšeg istočnoeuropskog bloka svrstavati u kolektivističke kulture, no da se istovremeno ne mogu smatrati niti individualističkim kulturama, već se na dimenziji kolektivizma i individualizma nalaze između primjerice SAD-a i Južne Koreje. Trommsdorff, Mayer i Albert (2004) su proučavajući individualizam i kolektivizam kroz tri generacije u Njemačkoj utvrdili da, iako su mlađe generacije sklonije individualizmu, i dalje postoji snažna orijentacija na zajedništvo koju tradicionalni Triandisov (1993) model individualizma i kolektivizma smatra dimenzijom kolektivizma. Međutim, autori ističu da je više riječ o europskim vrijednostima nego uobičajenoj podjeli na individualistička i kolektivistička društava, prema kojoj bi se Njemačka, ali i Hrvatska, mogle svrstati u individualistička društva. To dijelom objašnjava naš nalaz o podjednakoj važnosti subjektivne norme i percipirane bihevioralne kontrole u objašnjavanju namjere konstruktivne komunikacije. Naime, nalazi upućuju na znatno viši doprinos subjektivne norme u kolektivističkim društvima, te znatno viši doprinos percipirane bihevioralne kontrole $\mathrm{u}$ individualističkim društvima. Čini se da se Hrvatska nalazi između ova dva ekstrema, što se odražava u našim rezultatima gdje je percepcija što drugi očekuju da napravimo u datoj situaciji podjednako važna kao i percipirana kontrola da izvedemo određeno ponašanje pri formiranju namjera budućih postupaka. Percipirana bihevioralna kontrola $u$ našem je istraživanju imala i izravan doprinos na konstruktivnu komunikaciju prilikom sukoba, što je u skladu s Ajzenovim (2011) pretpostavkama. S obzirom na prirodu ponašanja komunikacije prilikom sukoba, koja dijelom ovisi i o partneru i njegovim reakcijama, ne možemo govoriti o potpunoj voljnoj kontroli nad izvođenjem ponašanja. No, u slučaju konstruktivne komunikacije prilikom sukoba u intimnoj vezi kao ciljnog ponašanja, percipirana bihevioralna kontrola dijelom zaista odražava stvarnu kontrolu nad ponašanjem, što je preduvjet postavljanja očekivanja da će percipirana bihevioralna kontrola na ponašanje djelovati i izravno, a ne samo posredno preko namjere (Ajzen i Madden, 1986). Naši rezultati potvrđuju ovu pretpostavku.

Iako su prema Ajzenovom (2011) modelu Teorije planiranog ponašanja međusobne korelacije stava, subjektivne norme i percipirane bihevioralne kontrole očekivane, naš model (Slika 5) samo dijelom potvrđuje to očekivanje. Naime, iako stav nisko, ali značajno korelira sa subjektivnom normom $(r=.18)$, te subjektivna norma s percipiranom bihevioralnom 
kontrolom $(r=.17)$, ne postoji korelacija stava i percipirane bihevioralne kontrole. Ovakav nalaz dodatna je potvrda svjesnosti sudionika našeg istraživanja da je konstruktivna komunikacije prilikom sukoba u intimnoj vezi voljno ponašanje, koje u određenom segmentu ovisi i o partneru, no da su u mogućnosti izvesti spomenuto ponašanje ukoliko tako žele. Stoga, percepciju kontrole nad ponašanjem u podjednakoj mjeri izražavaju i sudionici pozitivnog i negativnog stava prema konstruktivnoj komunikaciji prilikom sukoba. Nepostojanje korelacije između stava i percipirane bihevioralne kontrole upućuje i na mogućnost postojanja moderatorskog efekta, budući da je jedan od preduvjeta moderacije nepostojanje povezanosti između moderatora i nezavisne varijable. Brojne studije ukazale su na moderatorski učinak percipirane bihevioralne kontrole na vezu između stavova i subjektivne norme s namjerom ponašanja, na način da je veza između stavova i bihevioralne namjere, te subjektivne norme i bihevioralne namjere bila snažnija kod osoba s višom razinom percipirane bihevioralne kontrole, u odnosu na osobe niže percipirane bihevioralne kontrole (Bansal i Taylor, 2002; Connor i McMillan, 1999; Kidwell i Jewell, 2003; McMillan i Conner, 2003; Povey, Conner, Sparks, James i Shepard, 2000; Umeh i Patel, 2004; Castanier i sur., 2013; Yzer, 2014). Stoga bi u budućim istraživanjima svakako trebalo ispitati i moderatorski efekt percipirane bihevioralne kontrole.

\subsection{Vremenska perspektiva, atribucijski stil $i$ atribuiranje partnerovog negativnog ponašanja u kontekstu teorije planiranog ponašanja}

Nakon što je utvrđena prediktivna snaga osnovnog modela Teorije planiranog ponašanja za predviđanje konstruktivne komunikacije prilikom sukoba u bliskoj vezi, zanimalo nas je hoće li uključivanje vremenskih perspektiva, atribucijskog stila, te stila atribuiranja partnerovog negativnog ponašanja unaprijediti objašnjavanje konstruktivne komunikacije prilikom sukoba. Unatoč povećanoj složenosti, koja se odražava u smanjenju indeksa pristajanja u odnosu na osnovni model, model proširen spomenutim dodatnim konstruktima vrlo dobro pristaje podacima. Istovremeno objašnjava $6,8 \%$ varijance kriterija konstruktivne komunikacije više nego osnovni model, što je povećanje postotka objašnjene varijance za 26,4\%. Budući da prediktivnost dodatnih varijabli nije zanemariva, bez obzira na ponešto slabije indekse pristajanja, možemo zaključiti da prošireni model s dodanim varijablama vremenskih perspektiva, atribucijskog stila i načina atribuiranja partnerovog negativnog ponašanja omogućuje bolje predviđanje konstruktivne komunikacije prilikom sukoba. 
U okviru trećeg problema, ispitana je povezanost vremenskih perspektiva s elementima postuliranim Teorijom planiranog ponašanja. Očekivali smo da orijentacije na pozitivnu prošlost, hedonističku sadašnjost i budućnost pozitivno koreliraju sa stavom prema konstruktivnom rješavanju sukoba, a da orijentacije na hedonističku i fatalističku sadašnjost negativno koreliraju sa subjektivnom normom izvođenja ponašanja. Pretpostavljeno je i da će osobe izraženije fatalističke sadašnjosti imati sniženu percipiranu bihevioralnu kontrolu. No, rezultati su ukazali na drugačije obrasce povezanosti, čime hipoteze nisu potvrđene. Relevantnim dimenzijama pokazale su se samo dimenzije prošlosti (pozitivna i negativna), te sadašnjosti fatalističke. Dimenzije budućnosti i sadašnjosti hedonističke nisu bile povezane $\mathrm{s}$ ostalim elementima modela. Ajzen i Fishbein (2005) pozadinske faktore elemenata Teorije planiranog ponašanja objašnjavaju kao varijable koje objašnjavaju dio varijabiliteta stava o ponašanju, subjektivne norme i percipirane bihevioralne kontrole, te ih u modelu smještaju kao prethodnice istih (Slika 2). U tom smislu, dimenzije vremenskih perspektiva pokazale su se pozadinskim faktorima samo subjektivne norme i percipirane bihevioralne kontrole, dok stav prema konstruktivnoj komunikaciji nisu predviđale. Prošlost pozitivna i negativna pozitivno nisko su korelirale sa subjektivnom normom, pri čemu je povezanost prošlosti pozitivne bila dvostruko viša nego povezanost prošlosti negativne. Osobe koje su više usmjerene na prošlost više su usmjerene na odnose. To posebno vrijedi za osobe dominantne perspektive pozitivne prošlosti, koje su najviše usmjerene na odnose, održavaju najdugotrajnija prijateljstva i najbliskije su s članovima obitelji od svih vremenskih perspektiva (Zimbardo i Boyd, 1999). S obzirom da veliku važnost pridaju održavanju bliskih odnosa, moguće je da će biti motivirane ponašati se u skladu s očekivanjima drugih kako ne bi ugrozile te odnose. Istovremeno, svoje odnose s drugima percipiraju skladnima i ljude iz svoje okoline pozitivnima te je stoga očekivano da vjeruju da se njima bliski ljudi ponašaju na pozitivan način, te da od njih očekuju isto. Konstruktivna komunikacija prilikom sukoba smatra se u društvu pozitivnim ponašanjem te postoji snažna društvena norma da bi se tako trebalo ponašati prilikom sukoba. S druge strane, osobe izražene prošlosti negativne su osobe s nezadovoljavajućim međuljudskim odnosima, s manje prijatelja, no istovremeno osobe koje se ne vole isticati te su povučene. Usmjerene su na odnose, ali na negativne aspekte odnosa, o kojima često ruminiraju. Riječ je o osobama izraženije depresivnosti i anksioznosti, s lošijim mišljenjem o sebi. Iako sami često imaju nezadovoljavajuće bliske odnose, vjeruju da se njima bitne osobe ponašaju konstruktivno tijekom sukoba te isto ponašanje očekuju i od njih, bez obzira ispunjavaju li oni ta očekivanja ili ne, što se odražava u pozitivnoj povezanosti sa subjektivnom normom konstruktivne komunikacije. Prošlost negativna bila je povezana i s percipiranom bihevioralnom kontrolom, 
na način da su osobe izraženije prošlosti negativne imale osjećaj manje sposobnosti izvođenja ponašanja konstruktivne komunikacije prilikom sukoba, odnosno imale su sniženu percipiranu bihevioralnu kontrolu. Ako pobliže pogledamo profil prošlosti negativne, ovaj nalaz je razumljiv. Zbog ranijih negativnih iskustava, bilo stvarnih ili negativnih interpretacija neutralnih iskustava, osobe izražene prošlosti negativne ne vjeruju da se u budućim situacijama mogu ponašati konstruktivno, budući da u prošlim situacijama u bliskim vezama nisu mogle reagirati adekvatno, na što upućuje i manja stabilnost veza osoba usmjerenih na negativnu prošlost (Krznarić, Huić i Kamenov, 2013).

Sadašnjost fatalistička imala je direktan učinak na namjeru, a ne posredan preko stava, subjektivne norme i percipirane bihevioralne kontrole, te je stoga ne možemo smatrati pozadinskim faktorima u smislu kako ih tumače Ajzen i Fishbein (2005). Sadašnjost fatalistička s namjerom konstruktivne komunikacije u budućim sukobima korelirala je nisko negativno, ukazujući na tendenciju da su osobe koje smatraju da nemaju kontrolu nad vlastitim životom, te koje vjeruju da njihovi postupci i djela ne utječu na ishode u njihovom životu manje sklone imati namjeru u budućim sukobima s partnerom komunicirati konstruktivno. Takav rezultat je razumljiv, iako nije bilo očekivano da će postojati direktan efekt vremenskih perspektiva na namjeru ponašanja. Naime, stav prema nekom ponašanju, očekivanja drugih treba li se osoba ponašati na određeni način te doživljaj vlastite sposobnosti za izvođenje određenog ponašanja postaju irelevantni za formiranje namjere izvođenja samog ponašanja ukoliko osoba vjeruje da izvođenje tog ponašanja neće utjecati na ishod ikakve situacije. Zbog takvog uvjerenja neće biti motivirana za izvođenje ponašanja, što će se očitovati u sniženoj namjeri ponašanja. Također, osobe izražene sadašnjosti fatalističke imaju sklonost izvještavati o manjoj namjeri ponašanja nego što ona uistinu jest (Van Ittersum, 2012), što je također moglo dovesti do negativne povezanosti između ove vremenske perspektive i namjere konstruktivne komunikacije prilikom sukoba. Također je moguće da Teorija planiranog ponašanja nije podjednako učinkovita $u$ predviđanju ponašanja pojedinaca usmjerenih na sadašnjost, budući da slijed namjere praćene stvarnim ponašanjem iziskuje određenu razinu planiranja. Stoga je ova teorija možda primjerenija osobama usmjerenim na budućnost, budući da osobe izražene orijentacije na sadašnjost, posebno sadašnjost fatalističku, karakterizira manjak usmjerenosti ka planiranju budućnosti. Prošlost negativna i sadašnjost fatalistička su u umjerenoj pozitivnoj međusobnoj korelaciji, te osobe koje imaju negativno viđenje vlastite prošlosti ujedno imaju osjećaj manjka kontrole nad vlastitim životom i budućnosti, što zajedno upućuje da depresivni profil. Takav nalaz je u skladu s brojnim ranijim nalazima u području (Zimbardo i Boyd, 1999), budući da je riječ o neadaptivnim dimenzijama vremenskih perspektiva, povezanih s negativnim ishodima 
u životu. Prošlost pozitivna nije bila povezana s preostale dvije dimenzije vremenskih perspektiva u modelu. Vremenske perspektive nisu imale izravne efekte na konstruktivnu komunikaciju prilikom sukoba, ali su značajni na razini rizika od $1 \%$ bili neizravni niski efekti svih triju spomenutih vremenskih perspektiva na komunikaciju prilikom sukoba u vezi. Sukladno pretpostavljenom proširenom modelu Teorije planiranog ponašanja, očekivani su neizravni efekti i nepostojanje izravnih efekata. Efekt prošlosti pozitivne je bio pozitivan, što znači da osobe izraženije prošlosti pozitivne imaju veću vjerojatnost da će prilikom sukoba komunicirati konstruktivno, dok je ta vjerojatnost za osobe izražene prošlosti negativne i sadašnjosti fatalističke bila snižena (Tablica 10).

Osnovni model Teorije planiranog ponašanja proširen je i općenitim atribucijskim stilom, što je sadržano u četvrtom problemu. Pritom se relevantnom pokazala samo dimenzija stabilnosti, ali ne i dimenzije internalnosti i globalnosti. Dimenzija stabilnosti, odnosno indikator u kojoj mjeri osoba pozitivne događaje u svojem životu pripisuje uzrocima koji su stabilni u vremenu i uvijek prisutni, poput osobnih karakteristika, a negativne događaje nestabilnim uzrocima kao što su jednokratni događaji, predviđala je percipiranu bihevioralnu kontrolu konstruktivne komunikacije prilikom sukoba. Osobe sklonije pozitivne događaje pripisivati stabilnim, a negativne nestabilnim uzrocima, imale su doživljaj veće vlastite sposobnosti konstruktivne komunikacije prilikom sukoba. Time je djelomično potvrđena hipoteza vezana uz četvrti problem, budući da je pripisivanje negativnih uzroka nestabilnim uzrocima, a pozitivnih događaja stabilnim uzrocima aspekt pozitivnog atribucijskog stila za koji se pretpostavljalo da će biti povezan s povišenom percipiranom bihevioralnom kontrolom. Pozitivni atribucijski stil se zapravo sastoji od atribucija u vlastitu korist (za pozitivne događaje smo sami odgovorni i zaslužni, a negativni događaji su posljedica okolnosti ili slučaja), no on ujedno uključuje i element nerealističnog optimizma (Taylor i Brown, 1988). Nerealistični optimizam je vrsta obrambene atribucije pri kojoj osobe smatraju da će im se u budućnosti događati dobre stvari, a da će ih sve loše zaobići i neće se dogoditi baš njima. Stoga je razumljivo da osobe koje vjeruju da će im se u budućnosti događati dobre stvari, vjeruju da će moći komunicirati konstruktivno ako tako žele, budući da je riječ o ishodu koji se smatra generalno poželjnim ponašanjem. Dimenzija stabilnosti atribucija važna je u razumijevanju bihevioralne kontrole. Iako atribucijski stil mjeren Upitnikom atribucijskog stila ne mjeri dimenziju podložnosti kontroli događaja, kasnijim istraživanjima se ta dimenzija pokazala najvažnijom za razumijevanje raznih ishoda u životu, dok se dimenzija globalnosti pokazala najmanje značajnom (primjerice, Deuser i Anderson, 1995). Istraživanja su pokazala da je atribucijski stil kod kojeg osoba koja nema osjećaj kontrole nad svojim životom, događajima i 
ishodima i pritom pripisuje negativne događaje internalnim, stabilnim i globalnim faktorima, jasno povezan s depresivnom simptomatologijom, te da predstavlja faktor rizika za pojavu depresije i psihičkih poteškoća (Peterson i sur, 1982). Weinerov model o motivaciji za postignućem (1983; prema Wolf i Savickas, 1985) pretpostavlja da očekivanje uspjeha u budućnosti ovisi o atribucijama za prethodne ishode. Pritom je posebno važna dimenzija stabilnosti - ukoliko je uzrok pripisan stabilnim uzrocima, kao što je sposobnost, osoba će očekivati isti ishod za situacije u budućnosti. Uočavamo jasnu vezu vremenskih perspektiva i atribucijskog stila, posebno dimenzija prošlosti i atribucijske dimenzije stabilnosti. Ako pojedinac svoju prošlost doživljava pozitivno i vjeruju da su u njegovom dosadašnjem životu prevladavale pozitivne situacije (karakteristike prošlosti pozitivne) vjerovat će da su takvi ishodi posljedica stabilnih faktora u njegovom životu. Suprotno tome, ako ima negativno viđenje dosadašnjeg života te prethodna iskustva tumači negativno (što je tipično za prošlost negativnu) smatrat će da do takvih uvijek negativnih ishoda vode stabilni uzroci. Ovakvu racionalu potvrđuju i naši nalazi koji su utvrdili pozitivnu umjerenu korelaciju prošlosti negativne i stabilnosti, pri čemu viši rezultat na dimenziji stabilnosti ukazuje na veću sklonost pripisivanja negativnih ishoda nestabilnim uzrocima, a pozitivnih stabilnim. Ujedno, prošlost pozitivna bila je povezana umjereno negativno s dimenzijom stabilnosti.

U našem istraživanju korištene su dvije mjere atribucijskog stila, Upitnik atribucijskog stila koji mjeri općeniti atribucijski stil i Mjera atribucija u vezi, koja pruža uvid u način pripisivanja uzroka partnerovog negativnog ponašanja, te je specifična za kontekst ljubavne veze. Razlikovanje atribucijskog stila specifičnog za domenu od općenitog atribucijskog stila posljedica je različitog teorijskog viđenja atribucija. Pobornici općenitog atribucijskog stila vjeruju da postoji generalna sklonost atribuiranju na određeni način koja se odražava u raznim domenama života. Istraživanja nisu u potpunosti potvrdila ovu pretpostavku (Cutrona i sur., 1995). Cutrona i sur. (1995) utvrdili su da su rezultati na Upitniku atribucijskog stila slab prediktor atribucija za stvarne događaje u životu u raznim domenama, što je upućivalo na zaključak da i situacijski faktori imaju važnu ulogu. Stoga je sve više istraživača počelo izražavati sklonost korištenju mjera atribucija specifičnih za domenu, opravdavajući racionalu da iako postoji općeniti atribucijski stil, atribucijski stil za pojedine domene je specifičan, iako dijeli dio varijance s dimenzijama općenitog atribucijskog stila. Takvu teorijsku osnovu podržavaju i nalazi ovog istraživanja, kao i raniji nalazi Krznarić i Kamenov (2016), te Krznarić, Kamenov i Huić (2017). Mjera atribucija u vezi, kojom je utvrđen stil atribuiranja partnerovog negativnog ponašanja, ima više dimenzija, no za prošireni model Teorije planiranog ponašanja u našem istraživanju relevantnima su se pokazale samo dvije dimenzije: 
stabilnost i krivnja. Stabilnost se tiče procjene koliko je uzrok partnerovog negativnog ponašanja stabilan u vremenu, odnosno hoće li biti prisutan i u budućim situacijama, dok je krivnja odraz uvjerenja treba li partnera kriviti za njegov negativan postupak (Bradbury i Fincham, 1992). Dimenzija stabilnosti općenitog atribucijskog stila očekivano je bila povezana s dimenzijom stabilnosti atribucijskog stila specifičnog za kontekst intimne veze. Dok se u dimenziji stabilnosti općenitog atribucijskog stila odražava sklonost pripisivanju uzroka događaja u vlastitom životu, atribucije u domeni intimne veze tiču se pripisivanja uzroka partnerovog negativnog ponašanja, odnosno održavaju promišljanje zašto je partner napravio nešto negativno u kontekstu veze. Ove dvije vrste atribucija stabilnosti prema našim rezultatima koreliraju umjereno pozitivno. Negativni događaji u vezi prouzročeni partnerovim negativnim ponašanjem predstavljaju na neki način i negativan događaj u vlastitom životu, stoga je shvatljivo da dijele dio zajedničke varijance u interpretaciji uzroka takvih događaja. Dimenzija stabilnosti općenitog atribucijskog stila nisko pozitivno je korelirala i s pripisivanjem krivnje partneru za njegovo negativno ponašanje. Drugim riječima, osobe koje su sklonije negativne događaje u svojem životu pripisivati stabilnim uzrocima, sklonije su smatrati da partner zaslužuje da ga se krivi za nešto loše što je učinio. Očekivano, okrivljavanje partnera za loš postupak i uvjerenje da je uzrok partnerovog negativnog ponašanja stabilan u vremenu također su povezani, pa su dimenzije krivnje i stabilnosti Mjere atribucija u vezi korelirale umjereno pozitivno. Ako osoba vjeruje da je partner postupio loše zbog stabilnog uzroka, primjerice zbog svoje ličnosti, razumljivo je da će vjerovati da partnera treba kriviti zbog toga. S druge strane, ako je partner postupio negativno zbog promjenjivih okolnosti, kao što je trenutna situacija na poslu ili iznimno stresan dan, tada ga niti ne treba kriviti zbog toga jer je to bio jednokratan događaj. Heider (1958, prema McNulty i Karney, 2001) je doveo u vezu atribucije krivnje i stabilnosti, objašnjavajući da pripisivanje krivnje za određeni postupak osobi automatski znači pripisivanje krivnje za stabilnu osobinu. Suprotno tome, pronalaženje opravdanja za partnerovog negativan postupak, što je suprotan pol dimenzije pripisivanja krivnje $u$ konceptualnom smislu, razdvaja postupak od osobe čime se nužno stvara atribucija nestabilnog uzroka.

Kao i s dimenzijom stabilnosti općenitog atribucijskog stila, i dimenzija stabilnost Mjere atribucija $u$ vezi bila je negativno povezana $s$ vremenskom perspektivom prošlosti pozitivne. Budući da su osobe dominantne orijentacije na prošlost pozitivnu svoj cjelokupan život i bliske odnose sklone gledati u pozitivnom svjetlu, te su najzadovoljnije svojim bliskim odnosima, sklone su partnerov loš postupak pripisati nestabilnom uzroku i protumačiti da je riječ o uzroku koji neće biti prisutan u budućim situacijama. Takvo viđenje partnerskog odnosa, 
odnosno atribuiranje koje jača vezu i povjerenje u partnera, ponovno se očituje u činjenici da osobe usmjerene na prošlost pozitivnu imaju najdugotrajnije i najstabilnije ljubavne veze u odnosu na osobe drugih vremenskih perspektiva.

Dimenzije stila atribuiranja partnerovog negativnog ponašanja, odnosno Mjere atribucija u vezi, predviđale su i pojedine elemente modela Teorije planiranog ponašanja. Pripisivanje partnerovog negativnog ponašanja stabilnim uzrocima predviđalo je stav prema konstruktivnoj komunikaciji. Utvrđena korelacija bila je umjerena negativna, ukazujući na to da osobe koje su sklonije smatrati da su uzroci partnerovog negativnog ponašanja stabilni u vremenu ujedno imaju negativniji stav prema konstruktivnoj komunikaciji prilikom sukoba. Moguće je da, s obzirom na uvjerenje da je uzrok negativnog ponašanja stabilan u vremenu, vjeruju kako njihovi postupci poput konstruktivnog komuniciranja u situacijama sukoba neće promijeniti takav stabilan uzrok pa razvijaju stav o beskorisnosti takvog vida komunikacije. Stabilnost uzroka kojem pripisujemo partnerovo negativno ponašanje, osim neizravnog učinka na konstruktivnu komunikaciju preko stava o konstruktivnoj komunikaciji, imala je i izravan učinak na konstruktivnu komunikaciju prilikom sukoba. Stabilnost je korelirala $\mathrm{s}$ konstruktivnom komunikacijom nisko negativno, upućujući na to da su osobe koje partnerovo negativno ponašanje pripisuju stabilnim uzrocima sklone u vlastitoj ljubavnoj vezi zapažati manje konstruktivne komunikacije. Pritom valja imati na umu da je mjera konstruktivne komunikacije prilikom sukoba u našem istraživanju „kontaminirana“ dijelom i partnerovim postupcima, pa je moguće da je smanjena procjena konstruktivne komunikacije odraz uvjerenja da partner ima takvu ličnost ili drugu stabilnu karakteristiku zbog koje komunicira neadekvatno i zbog koje postupa negativno, što bi bio stabilan uzrok. Istovremeno, osoba koja smatra da partner postupa negativno zbog stabilnih uzroka, biti će manje sklona energiju usmjeravati u konstruktivnu komunikaciju kojom bi mogla riješiti probleme u vezi jer će zbog pripisivanja stabilnosti uzroka vjerovati da su problemi nerješivi. Dimenzija stabilnosti atribucija uzroka partnerovog negativnog ponašanja bitna je za razumijevanje više raznih ponašanja u vezi, prvenstveno za odustajanje od pokušaja rješavanja problema u vezi koje proizlazi iz uvjerenja da su problemi nerješivi. U korijenu ove pojave leži fenomen naučene bespomoćnosti, koju je Martin Seligman (1972) definirao kao pasivno prihvaćanje neugodnih aspekata u životu ili neugodnih iskustava i podražaja, bez pokušaja utjecanja na situaciju, bilo bijegom iz situacije ili suprotstavljanjem izvoru neugode. Ovakvo stanje proizlazi iz ranijih iskustava osobe, koja je bila izložena neugodnoj bezizlaznoj situaciji te je naučila da nad njom nema nadzora. Problem se javlja kada osoba generalizira takvu reakciju i na one situacije u kojima postoji mogućnost utjecaja na situaciju. Naučena bespomoćnost je i ključ za razumijevanje 
depresivnosti, koja se javlja kada osoba očekuje negativna iskustva u budućem životu, pri čemu vjeruje da nad time neće imati nikakve kontrole i mogućnosti utjecaja kako bi takva iskustva spriječila ili promijenila. Osobe kod kojih je prisutna naučena bespomoćnost probleme u vezi pripisuju stabilnim uzrocima, očekuju da će isti uzroci biti prisutni i u budućnosti, te neće niti pokušavati problem riješiti jer će ga smatrati nerješivim iako on to vjerojatno nije.

Uvjerenje da partnera treba kriviti zbog njegovih negativnih postupaka, odnosno dimenzija krivnje Mjere atribucija u vezi, bila je povezana s percipiranom bihevioralnom kontrolom nisko negativno. To znači da što je osoba sklonija kriviti partnera zbog njegovih negativnih postupaka, manje je sklona osjećati da može komunicirati konstruktivno, odnosno da svojim postupcima može dovesti do konstruktivnog komuniciranja nje i partnera kao para prilikom sukoba. Dimenzija krivnje ima jasnu implicitnu konotaciju da partner nešto negativno čini namjerno, a ne slučajno. Iako u Mjeri atribucija u vezi postoji dimenzija koja propituje je li partner nešto negativno napravio namjerno ili nesvjesno, ona se nije pokazala relevantnom u našem modelu. Međutim, u ranijim istraživanjima često se pokazalo da je zapravo „upletena“ u dimenziju krivnje na način da u mnogim slučajevima predstavlja preduvjet za krivljenje partnera (McNulty i Karney, 2001).

Usporedbom osnovnog modela Teorije planiranog ponašanja i modela proširenog vremenskim perspektivama, općenitim atribucijskim stilom i atribuiranjem partnerovog negativnog ponašanja na prvi pogled uočavam da je osnovni model parsimoničniji što se odražava u boljim indeksima pristajanja podacima, budući da je parsimonija relevantan faktor u izračunu indeksa pristajanja. No i prošireni model dobro pristaje podacima, pa je za zaključak o opravdanosti proširenja modela presudan bio postotak objašnjene varijance kriterija, odnosno konstruktivne komunikacije prilikom sukoba. Dok osnovni model Teorije planiranog ponašanja objašnjava otprilike jednu četvrtinu varijance (točnije 25.7\%), prošireni model je objasnio jednu trećinu varijance (odnosno 32.5\%), što je zamjetno povećanje. Stoga je nedvojbeno opravdano proširenje modela uključenim varijablama, budući da pruža novi uvid u problematiku i razjašnjava dio kompleksnosti fenomena komunikacije prilikom sukoba u bliskim vezama.

\subsection{Metodološka ograničenja i smjernice za buduća istraživanja}

Provedeno istraživanje imalo je određena metodološka ograničenja, na koja je potrebno osvrnuti se. Sudionici su za potrebe ovog istraživanja regrutirani putem socijalnih mreža studenata psihologije, a kriterij za odabir je bio da je riječ o osobama u dobi od 18 do 30 godina koje su se u trenutku provedbe istraživanja nalazile u ozbiljnoj ljubavnoj vezi. Dob od 18 do 30 
godina odabrana je kao razdoblje mlađe odrasle dobi, u kojem se formiraju stabilne ljubavne veze te obrasci ponašanja u istima. Međutim, ne postoji konsenzus među istraživačima što je mlađa odrasla dob. Neki istraživači smatraju da je riječ o dobi od 18 do 25 godina (v. Tatalović Vorkapić, 2013; Savin - Williams i Ream, 2006, Whitton i Kuryluk, 2012), no drugi ističu promjene prisutne u modernom društvu poput kasnijeg zasnivanja ozbiljnih veza i roditeljstva, dužeg perioda obrazovanja, kasnijeg zapošljavanja te dužeg ostanka u roditeljskom domu, što je posebno očito u Hrvatskoj. Zbog toga pomiču granice mlađe odrasle dobi do 30 (v. Cui, Fincham i Pasley, 2008), pa čak i 40 godina života. Tako primjerice Državni zavod za statistiku mlađom odraslom dobnom skupinom smatra osobe od 20 do 39 godina (Pekač i Petrić, 2015). Stoga je moguće da bi odabirom drugačijih dobnih granica mlađe odrasle dobi bili dobiveni ponešto drugačiji rezultati. No, uzevši u obzir da je prosječna dob stupanja u brak u Hrvatskoj za žene 28,2 godine, a za muškarce 31 godinu, a da je prosječna dob prvorotkinje 28,6 godina (Državni zavod za statistiku, 2017), postavljanje dobnih granica između 18 i 30 godina za potrebe ovog istraživanja čini se opravdanom. No, trebamo biti svjesni ograničene mogućnosti generalizacije rezultata na druge dobne skupine.

Također, upitna je mogućnost generalizacije nalaza na osobe u drugim oblicima partnerskih odnosa (primjerice, „neozbiljna“" veza, brak, kohabitacija). Naime, u istraživanju su sudjelovale osobe koje su u ozbiljnoj ljubavnoj vezi, pri čemu je ozbiljna veza definirana kao ona za koju sam sudionik vjeruje da je ozbiljna. Iako je opravdano koristiti ovakav subjektivni kriterij jer se osobni osjećaj važnosti bliskog odnosa ne može u potpunosti objektivizirati, ozbiljnost veze se mogla pobliže operacionalizirati. Primjerice, $u$ istraživanje su mogli biti uključeni oni sudionici koji su partnera upoznali s prijateljima ili obitelji, koji su razmatrali mogućnost zajedničkog života ili slično. Na taj način bio bi uveden „objektivniji“ kriterij ozbiljnosti veze. No, s obzirom na predmet istraživanja, osobna percepcija ozbiljnosti veze čini se najprimjerenijom.

U uzorku su prevladavali sudionici koji svoju vezu procjenjuju kvalitetnom, odnosno oni koji su svojom vezom uglavnom zadovoljni. Riječ je o čestom problemu u istraživanjima u domeni intimnih odnosa, koji je problem dobrovoljnosti sudjelovanja u istraživanjima. Naime, veća je vjerojatnost da će u istraživanjima ljubavnih odnosa na sudjelovanje pristati osobe koje svoji odnos procjenjuju kvalitetnim, dok osobe u manje kvalitetnim odnosima nisu sklone o istima izvještavati. Riječ je o problemu koji nije moguće izbjeći, no povećani varijabilitet kvalitete veze rezultirao bi vjerojatno povećanim varijabilitetom na mjerama ostalih konstrukata u istraživanju, zbog čega bi posljedično zabilježeni efekti bili još izraženiji. Lavner, Karney i Bradbury (2016) utvrdili su da komunikacija u vezi relativno slabo predviđa 
zadovoljstvo vezom, što je u skladu s nalazima Lawrencea i Bradburyja (2007) da samo teži oblici loše komunikacije, primjerice s elementima nasilja, narušavaju procjene zadovoljstva vezom. Međutim, zadovoljstvo vezom je relativno snažan prediktor komunikacije u vezi, što donekle upućuje na smjer kauzalnosti.

Način regrutacije sudionika također predstavlja mogući nedostatak. Budući da su podaci prikupljani anonimno i online putem nakon što su sudionici regrutirani od strane studenata psihologije, postoji mogućnost da su neke osobe dale neistinite sociodemografske podatke. Međutim, s obzirom da su dobiveni očekivani smjerovi povezanosti, malo je vjerojatno da je u uzorku bio znatniji broj takvih slučajeva. Kako su sudionici regrutirani iz socijalnih mreža studenata, prikupljeni uzorak nije reprezentativan za populaciju mladih od 18 do 30 godina u Hrvatskoj. Veća je zastupljenost obrazovanijih osoba, te osoba iz urbanih sredina nego što je u općoj populaciji. Moguće je da obrazovanije osobe adekvatnije komuniciraju i verbalno izražavaju osjećaje, te da su stoga sudionici u našem uzorku skloniji konstruktivnoj komunikaciji prilikom sukoba. Razina obrazovanja također se može odražavati i u izraženosti stavova prema takvoj komunikaciji, te prvenstveno subjektivnoj normi ponašanja. Naime, pojedinci se obično učestalije druže s osobama sličnog socioekonomskog statusa, te je moguće da se u grupama različitog socioekonomskog statusa percipiraju različita očekivana ponašanja u raznim domenama, pa tako i u ophođenju u vezi. Razina obrazovanja i veličina mjesta u kojoj su osobe odrasle donekle je povezana i s izraženošću stava o rodnoj i spolnoj ravnopravnosti (Shu, 2004; Boehnke, 2011) što se može snažno odražavati na prevladavajući način komunikacije u vezi te izraženost obrasca konstruktivne komunikacije u vezi kao rodno ravnopravnog obrasca (Pranjić, 2012).

Budući da su temelj ovog istraživanja povezanosti među varijablama, u ovom istraživanju, kao i u srodnima, prisutne su metodološke manjkavosti povezane s upotrebom samoprocjena konstrukata od interesa. Relevantne varijable ispitane su metodom samoiskaza, te je moguće da je došlo do tzv. efekta zajedničke metode (eng. common method effect). Ovaj efekt se očituje u vidu precijenjenih korelacija među varijablama uslijed primjene iste metode mjerenja varijabli (Podsakoff i sur., 2003). Iako je vjerojatno da je efekt zajedničke metode djelovao na intenzitet povezanosti među varijablama u određenoj mjeri, nije izgledno da je on isključivi razlog nalaska spomenutih korelacija. Naime, postulati Teorije planiranog ponašanja potvrđeni su brojnim ranijim istraživanjima, a povezanosti konstrukata vremenskih perspektiva i atribucijskog stila te atribuiranja partnerovog negativnog ponašanja $s$ konstruktivnom komunikacijom potvrđene su više puta, uz prisutnost snažnog teorijskog uporišta. Osnovni problem samoprocjena je da mogu biti opterećene sklonošću sudionika davanju socijalno 
poželjnih odgovora. Ta sklonost posebno dolazi do izražaja u slučaju osjetljivih pitanja, kakva pitanja u domeni bliskih odnosa i jesu. Iako je prilično jasno da društvo favorizira konstruktivnu komunikaciju prilikom sukoba, te je agresivno ponašanje u bliskim vezama javno definirano kao neprihvatljivo, očigledno je takvo ponašanje i dalje prisutno u hrvatskom društvu. No, moguće je da je sudionicima teško priznati postojanje takvih ponašajnih obrazaca u njihovim vezama, te da je došlo u određenoj mjeri do socijalno poželjnog odgovaranja. Međutim, socijalno poželjno odgovaranje na varijablama stava, subjektivne norme, percipirane bihevioralne kontrole i namjere konstruktivne komunikacije, kao i na mjeri same konstruktivne komunikacije u vezi očitovalo bi se u smanjenju raspona zabilježenih odgovora, što bi se očitovalo u smanjenju zabilježenih efekata. Stoga, ukoliko je i došlo do učestalijeg davanja socijalno poželjnih odgovora, oni su umanjili stvarne efekte te bi dobiveni rezultati bili još izraženiji da do istoga nije došlo. No, iako je u upitniku naglašeno da nema točnih i netočnih odgovora i da sudionici trebaju odgovarati iskreno, ostaje prisutan metodološki propust ovog istraživanja što sklonost socijalno poželjnom odgovaranju nije odmjerena nekom od dostupnih skala, a njeni efekti statistički eliminirani iz dobivenih rezultata. Zbog efekta zajedničke metode i problema vezanih uz samoprocjene u budućim istraživanjima bilo bi korisno ispitati istraživane fenomene različitim metodama. Konstrukt konstruktivne komunikacije bi bio posebno pogodan za opažanje, međutim zasigurno bi rezultati bili ponešto različiti zbog artificijelnosti takve situacije i posljedičnog smanjenja vanjske valjanosti. Stoga se čini da, unatoč eventualnim problemima koji se javljaju s upitničkim mjerama, ova metoda ostaje najprikladnija za ispitivanje konstruktivne komunikacije prilikom sukoba u bliskim vezama.

Unutarnje procese koji nisu dostupni opažanju idealno bi bilo mjeriti za vrijeme tog ponašanja. No, kako to nije moguće bez da se ciljano ponašanje prekida, takve konstrukte možemo mjeriti prije ili poslije ponašanja. Ovo istraživanje je provedeno $u$ dvije vremenske točke. U prvoj točki odmjereni su elementi definirani Teorijom planiranog ponašanja (stav prema konstruktivnoj komunikaciji, subjektivna norma, percipirana bihevioralna kontrola, te namjera konstruktivne komunikacije), dimenzije vremenskih perspektiva, atribucijski stil i atribuiranje partnerovog negativnog ponašanja. Mjesec dana nakon prve točke mjerenja, uslijedila je druga u kojoj je izmjerena izraženost konstruktivne komunikacije tijekom sukoba u vezi koji se dogodio u proteklih mjesec dana, odnosno između dvije vremenske točke mjerenja. Pritom treba imati na umu da nije svim sudionicima protekao jednak vremenski interval od sukoba u vezi do ispitivanja komunikacije prilikom sukoba. Moguće je da su neki sudionici imali sukob dvadesetak dana prije mjerenja, a neki svega dva dana. Zbog toga prisjećanje sukoba i njegovih karakteristika nije bilo jednako pouzdano kod svih sudionika, što 
predstavlja ograničenje ovog istraživanja. U budućim istraživanjima mogao bi se osmisliti nacrt u kojem bi ispitanici odmah po okončanju sukoba samostalno pristupili poveznici na kojoj bi se nalazio upitnik, te izvijestili o komunikaciji prilikom proteklog sukoba. Moguće je da je u nekim vezama bilo i više od jednog sukoba u jednomjesečnom razdoblju, što je kod sudionika moglo dovesti do određene razine nesigurnosti temeljem kojeg sukoba da ispune upitnik. No, budući da znamo da su obrasci komunikacije u vezi s istim partnerom prilično stabilni, razumno je pretpostaviti da su se svi sukobi odvili na sličan način, te da je samo manji broj sudionika bio suočen sa spomenutom nedoumicom.

Mjerenje elemenata Teorije planiranog ponašanja u jednoj točki, te kasnije mjerenje ciljnog ponašanja ključno je $u$ ispitivanjima primjene Teorije planiranog ponašanja. Naime, to što prediktori vremenski prethode kriteriju, u ovom slučaju konstruktivnoj komunikaciji prilikom sukoba, jedan je od preduvjeta zaključivanja o uzročnosti. Međutim, iako ovakav nacrt pruža više argumenata za zaključivanje o uzročnosti u odnosu na klasičan kros-sekcijski nacrt korelacijskog tipa, i ovome je svojstvena nemogućnost kauzalnog zaključivanja o odnosima među varijablama. Sussman i Gifford (2019) problematizirali su pitanje kauzalnosti u Teoriji planiranog ponašanja. Prema Teoriji planiranog ponašanja, stav, subjektivna norma i percipirana bihevioralna kontrola dovode do stvaranja namjere ponašanja. Opisani odnos je uzročno- posljedičan i jednosmjeran. No, Sussman i Gifford (2019) uočavaju da je ta pretpostavka rijetko ili gotovo nikada testirana. Kada i jest ispitivan smjer kauzalnosti, to se činilo statistički, a ne eksperimentalno. Sussman i Gifford (2019) navode nekoliko argumenata $\mathrm{u}$ prilog pretpostavci da formiranje namjere ponašanja mijenja stav, subjektivnu normu $\mathrm{u}$ percipiranu bihevioralnu kontrolu, čime i suprotan smjer kauzalnosti postaje moguć. To su prvenstveno istraživanja u području kognitivne disonance, efekt lažnog konsenzusa i efekt javnog izražavanja predanosti. Primjerice, navode kako kognitivna disonanca objašnjava da nakon što pojedinac odluči uložiti novac kladeći se na određenog konja, čin postavljanja bihevioralne namjere posljedično mijenja stav o tom konju koji postaje pozitivniji (Brownstein, Read i Simon, 2004, prema Sussman i Gifford, 2019). Navode i da osobe koje odluče prekršiti neko pravilo, posljedično počinju smatrati da i drugi krše isto pravilo, odnosno namjera ponašanja se odražava na promjenu subjektivne norme (Monin i Norton, 2003, prema Sussman i Gifford, 2019). Armor i Taylor (2003, prema Sussman i Gifford, 2019) su pokazali da jednom kad se formira namjera ponašanja, raste percipirana bihevioralna kontrola vezana uz to ponašanje. Pretpostavku o suprotnom smjeru kauzalnosti od namjere ponašanja ka stavu, subjektivnoj normi i percipiranoj bihevioralnoj kontroli istražili su provođenjem korelacijskom studijom, eksperimentalno u laboratorijskim uvjetima te terenskim kvazi- eksperimentom. 
Utvrdili su postojanje recipročnih veza, odnosno povratne sprege, između stava i subjektivne norme s jedne strane i namjere ponašanja s druge strane. Dakle, iako stav i subjektivna norma utječu na formiranje namjere ponašanja, jednom formirana ponašajna namjera mijenja stav o ponašanju i subjektivnu normu. Nije utvrđen efekt za percipiranu bihevioralnu kontrolu. Stoga je jedno od ograničenja našeg istraživanja zasigurno i postojanje neispitane mogućnosti povratne sprege među elementima modela Teorije planiranog ponašanja. Međutim, Sussman i Gifford (2019) naglašavaju da je opisani problem smjera kauzalnosti prvenstveno svojstven kros- sekcijskim nacrtima koji ispituju Teoriju planiranog ponašanja, a u kojima se model Teorije planiranog ponašanja i ciljno ponašanje ispituju u istom trenutku. Iako su takva istraživanja najčešća, riječ je o metodološki nelogičnim istraživanjima iz nekoliko razloga. Prvo, najčešće se zaustavljaju na ispitivanju namjere, te često niti ne ispituju stvarno ponašanje, pretpostavljajući u literaturi često spominjanu postavku da je namjera ponašanja najbolji prediktor stvarnog ponašanja. Drugo, ako i ispituju stvarno ponašanje, nije moguće ispitati buduće ponašanje jer se sve mjeri u istom trenutku pa se zapravo utvrđuje veza trenutnog stava, trenutne subjektivne norme, trenutne percipirane bihevioralne kontrole te namjere ponašanja s prošlim ponašanjem. Dakle, zahvaćaju se stav i subjektivna norma koji su već izmijenjeni povratnom spregom nakon ranijeg izvođenja ispitivanog ponašanja. Primjerice, ako ispitujemo stav, subjektivnu normu i percipiranu bihevioralnu kontrolu vezanu uz izvođenje vježbi povećanja tjelesne snage, te kao mjeru ponašanja ispitanike pitamo koliko puta su u nekom prethodnom razdoblju izvodili takve vježbe, samo izvođenje ili ne izvođenje tih vježbi već je promijenilo njihov stav o vježbanju i percepciju o tome vježbaju li i drugi. Sussman i Gifford (2019) napominju da je problem smjera kauzalnosti u znatno manjoj mjeri prisutan $u$ istraživanjima, kao što je i naše, koja u odvojenim vremenskim točkama ispituju elemente modela Teorije planiranog ponašanja i ciljno ponašanje. Vremenski odmak između mjerenja prediktora i kriterija omogućuje puno veći stupanj sigurnosti u zaključke o smjeru kauzalnosti. Stoga je jedna od prednosti našeg istraživanja upravo nacrt u kojem je konstruktivna komunikacija prilikom sukoba u vezi izmjerena mjesec dana nakon mjerenja stava, subjektivne norme, percipirane bihevioralne kontrole i namjere konstruktivne komunikacije prilikom sukoba.

Primjena ovakvog nacrta omogućila je provedbu istraživanja u uvjetima koji su mnogo sličniji onima u kojima se fenomeni od interesa prirodno manifestiraju, no što bi to bio slučaj kod provedbe sličnog istraživanja u kontroliranim uvjetima. Eksperimentalna istraživanja komunikacije prilikom sukoba postoje, no karakterizira ih značajno snižena vanjska valjanost budući da se znatno razlikuju od životnih situacija u kojima se partnerski sukobi inače odvijaju. 
Najčešće je zapravo riječ o razgovorima o temama za koje istraživači procjene da bi mogle biti konfliktne ili osjetljive, iako određenim parovima možda uopće nisu. Stoga su danas takva istraživanja mnogo manje zastupljena nego ranijih desetljeća. Imajući u vidu artificijelnost ispitivanja komunikacije u eksperimentalnim uvjetima, očigledno je da je ispitivanje komunikacije prilikom sukoba upitničkom mjerom bilo prikladnije s obzirom na ciljeve ovog rada.

\subsection{Znanstveni i praktični doprinos}

Provedeno istraživanje jedna je od rijetkih primjena Teorije planiranog ponašanja $u$ području bliskih odnosa, posebice partnerskih odnosa. Ovaj rad pruža podršku prediktivnosti Teorije planiranog ponašanja i u kontekstu ponašanja koja nisu u potpunosti pod kontrolom pojedinca, već je riječ o ponašanjima s dimenzijom interakcije između dvije osobe, kao što je slučaj s komunikacijom prilikom sukoba. Provedenim istraživanjem, model Teorije planiranog ponašanja proširen je vremenskim perspektivama, atribucijskim stilom i stilom atribuiranja partnerovog negativnog ponašanja, što do sada nije bio slučaj $u$ istraživanjima Teorije planiranog ponašanja. Vremenske perspektive i atribucije pokazale su se teorijski važnim antecedentima ključnih elemenata Teorije planiranog ponašanja, doprinoseći fundusu znanja o samoj teoriji, ali i razumijevanju mehanizama preko kojih dispozicijske karakteristike poput vremenskih perspektiva i stila atribuiranja djeluju na namjeru ponašanja, te posljedično i samo ponašanje konstruktivne komunikacije prilikom sukoba u partnerskom odnosu.

Doprinos ovog istraživanja predstavlja i činjenica da se istraživačke nalaze koji su dosad uglavnom dobiveni u zapadnom kulturalnom kruga SAD-a, Kanade i središnje Europe prenosi u bitno drugačiji društveni kontekst partnerskih odnosa koji prevladava u jugoistočnoj Europi. Većina nalaza replicirana je našim istraživanjem i u hrvatskom kontekstu. Potvrđeno je funkcioniranje Teorije planiranog ponašanja za predviđanje komunikacije prilikom sukoba, te važnost uključivanja vremenskih perspektiva i atribucijskog stila u razumijevanje dinamike partnerskih odnosa. Istovremeno, istraživanje je rezultiralo i nekim nalazima koji odudaraju od prevladavajućih zaključaka stranih istraživanja. Vremenska perspektiva budućnosti nije se pokazala prediktivnom za elemente modela Teorije planiranog ponašanja, kao niti za konstruktivnu komunikaciju prilikom sukoba. Dimenzija globalnosti također nije relevantna i nije pronašla svoje mjesto u proširenom modelu, a svega su se dvije dimenzije atribuiranja partnerovog negativnog ponašanja pokazale relevantnima u kontekstu našeg istraživanja, iako je riječ o dobro istraženim konceptima u domeni bliskih odnosa. a koji U slučaju da se u 
narednim provjerama ovi odstupajući nalazi pokažu stabilnima, možemo razmatrati mogućnost postojanja kros-kulturalno specifičnih odrednica konstruktivne komunikacije prilikom sukoba u bliskim vezama.

U današnje doba sve učestalijih razvoda brakova, ali i sve većeg broja prekida koje ljudi doživljavaju u životu, od posebne je važnosti razumijevanje komunikacije u bliskim vezama. Naime, upravo je neadekvatna komunikacija najčešći povod ili uzrok prekida. Stoga je nužno bolje razumijevanje elemenata uključenih u pozitivne, ali i negativne obrasce komunikacije. Poseban značaj i važnost istraživanjima komunikacije u vezi pruža subjektivna važnost bliskih veza koje osobe navode. To je posebice tako u istraživanoj dobnoj skupini, među mladima na prijelazu u odraslu dob, koji izvještavaju o zaokupljenosti romantičnim osjećajima, te stavljaju poseban naglasak na važnost veza u svom životu. Nezadovoljavajuća komunikacija najčešći je razlog zašto parovi traže stručnu pomoć (Doss, Simpson i Christensen, 2004), a terapeuti procjenjuju da neadekvatna komunikacija najviše oštećuje partnerski odnos (Geiss i O'Leary, 1981). Stoga je poboljšanje komunikacije bio primarni cilj vodećih modela prevencije (Woods i sur., 2014) i intervencije (Benson i sur., 2012), potaknut tom percipiranom potrebom i pretpostavkom da je komunikacija ključan prediktor zadovoljstva vezom. Unatoč rezultatima nekih istraživanja koja ukazuju da odnos komunikacije i zadovoljstva vezom nije tako jednostavan, te da samo neki oblici nepoželjne komunikacije ozbiljno narušavaju vezu, komunikacija ostaje najjasniji prediktor, te prediktor na koji je lakše utjecati intervencijama nego na primjerice dispozicijske varijable. Intervencije usmjerene na poboljšanje komunikacije često se nisu pokazale dovoljno efikasnima, no našim istraživanjima otvoren je put razumijevanju mehanizama koji dovode do namjere konstruktivne komunikacije prilikom sukoba, a posljedično i stvarne konstruktivne komunikacije prilikom sukoba u bliskoj vezi. Stoga bi kvalitetne intervencije trebale staviti naglasak na promjenu neadekvatnih stavova o konstruktivnoj komunikaciji, uz istovremeno naglašavanje prisutnosti norme takvog ponašanja te jačanje osjećaja samoefikasnosti odnosno kontrole nad izvođenjem takvog ponašanja. Uz osvješćivanje važnosti stavova, subjektivne norme i percipirane bihevioralne kontrole, takve intervencije trebale bi uključivati podučavanje parova o situacijskim odrednicama koje su se pokazale bitnima za percepciju bihevioralne kontrole nad konstruktivnom komunikacijom (primjerice, koliko je važno diskusiju o temi sukoba pokrenuti u situaciji kada partneri nisu umorni, kada nisu prisutni drugi ljudi i slično). Takve intervencije, utemeljene na Teoriji planiranog ponašanja, nadilaze razinu podučavanja kvalitetnoj komunikaciji u smislu kako razgovarati o problemu, te bi stoga mogle imati robusnije i dugotrajnije učinke od klasičnih intervencija u ovom području. Nadalje, naše istraživanje ukazalo je na važnost atribucijskog 
stila, odnosno načina na koji objašnjavamo pozitivne i negativne događaje u vlastitom života i uzroka kojima pripisujemo partnerovo negativno ponašanje. Intervencijama bi partnerima trebalo ukazati na "slijepe točke" u njihovom atribuiranju i osvijestiti cikličnost veza između komunikacije, atribuiranja i zadovoljstva vezom koja proizlazi iz Teorije socijalnog učenja. Osvješćivanjem tih uglavnom nesvjesnih procesa povećala bi se vjerojatnost zaustavljanja i prekidanja negativnog ciklusa koji vodi deterioraciji veze. Osim atribucijskog stila, važnim su se pokazale i vremenske perspektive. Ispravljanjem pretjerane izraženosti neadaptivnih dimenzija, kao posljedica ranih iskustava, mogla bi se ostvariti veća podudarnosti vremenskih orijentacija između partnera ali i kvalitetnije funkcioniranje pojedinca, što bi posljedično dovelo do povećanja percipirane bihevioralne kontrole nad konstruktivnom komunikacijom, subjektivne norme takve vrste komunikacije, te namjere komuniciranja na konstruktivan način u budućim sukobima. 


\section{ZAKLJUČAK}

Provedenim istraživanjem ispitali smo ulogu kognitivnih i motivacijskih činitelja $u$ predviđanju konstruktivne komunikacije prilikom sukoba u bliskim vezama. Zanimalo nas je može li se konstruktivna komunikacija prilikom sukoba u bliskim vezama predvidjeti korištenjem modela Teorije planiranog ponašanja, odnosno temeljem stava o ponašanju, subjektivne norme, percipirane bihevioralne kontrole te namjere konstruktivne komunikacije prilikom sukoba. U okviru prvog problema, rezultati su potvrdili hipotezu pokazavši da su pozitivan stav prema konstruktivnom rješavanju sukoba, izraženija subjektivna norma konstruktivne komunikacije, te viša percipirana bihevioralna kontrola pozitivno povezani s namjerom konstruktivne komunikacije i izraženošću ciljnog ponašanja, odnosno konstruktivnog rješavanja sukoba. Kao najsnažnija pojedinačna odrednica namjere ističe se stav prema ponašanju, iako su za namjeru ponašanja prediktivni i subjektivna norma konstruktivne komunikacije i percipirana bihevioralna kontrola nad konstruktivnom komunikacijom. Svi elementi Teorije planiranog ponašanja pozitivno koreliraju s kriterijskom varijablom konstruktivne komunikacije prilikom sukoba. Mogućnost predviđanja konstruktivne komunikacije prilikom sukoba provjerena je metodologijom strukturalnog modeliranja, koja je ukazala na to da model Teorije planiranog ponašanja dobro pristaje podacima, te objašnjava jednu četvrtinu varijance konstruktivne komunikacije prilikom sukoba.

Model Teorije planiranog ponašanja proširen je dimenzijama vremenskih perspektiva, atribucijskog stila i atribuiranja partnerovog negativnog ponašanja. Provjerene su povezanosti pojedinih vremenskih perspektiva sa stavom prema konstruktivnom rješavanju sukoba, subjektivnom normom izvođenja ponašanja, te percipiranom bihevioralnom kontrolom. Analiza izravnih i neizravnih učinaka rezultirala je sljedećim zaključcima. Suprotno očekivanjima, dimenzije sadašnjosti hedonističke i budućnosti nisu bile povezane s elementima modela Teorije planiranog ponašanja. Iako je očekivano da orijentacije na pozitivnu prošlost, hedonističku sadašnjost i budućnost pozitivno koreliraju sa stavom prema konstruktivnom rješavanju sukoba, rezultati su opovrgnuli ovu pretpostavku, budući da niti jedna dimenzija vremenskih perspektiva nije bila povezana sa stavom prema konstruktivnoj komunikaciji prilikom sukoba. Orijentacija na prošlost, i pozitivnu i negativnu, predviđala je subjektivnu normu konstruktivne komunikacije, iako je bilo očekivano da će prediktori subjektivne norme biti dimenzije sadašnjosti fatalističke i hedonističke. Sadašnjost fatalistička previđala je direktno namjeru konstruktivne komunikacije, no nije bila povezana s percipiranom bihevioralnom kontrolom, a što je bilo pretpostavljeno u okviru trećeg problema. Moguće 
objašnjenje direktne veze sadašnjosti fatalističke i namjere konstruktivne komunikacije krije se u sklonosti osoba izražene sadašnjosti fatalističke da sustavno izvještavaju o manjoj namjeri ponašanja nego što ona uistinu jest, odnosno da podcjenjuju vlastitu namjeru ponašanja. Nadalje, moguće je da je model Teorije planiranog ponašanja općenito manje prikladan za predviđanje ponašanja osoba usmjerenih na sadašnjost fatalističku, budući da im je svojstven manjak usmjerenosti na planiranje budućih ponašanja. Prošlost negativna također je predviđala percipiranu bihevioralnu kontrolu, na način da su osobe negativnih životnih iskustava, poučene ranijim negativnim događajima $u$ životu koje možda nisu mogle kontrolirati, bile sklone vjerovati da imaju manju kontrolu nad konstruktivnom komunikacijom.

Atribucijski stil, specifičnije dimenzija stabilnosti, predviđala je percipiranu bihevioralnu kontrolu, iako dimenzija globalnosti nije pronašla svoje mjesto u modelu, pa možemo reći da je hipoteza u okviru četvrtog problema djelomično potvrđena. U model je uključen i specifičan atribucijski stil u kontekstu intimne veze, odnosno pripisivanje uzroka partnerovog negativnog ponašanja, za koji je bilo predviđeno da će osobe koje pozitivnije atribuiraju ponašanje partnera u intimnoj vezi biti više sklone konstruktivnom rješavanju sukoba, dok će sklonost negativnom atribuiranju ponašanja partnera biti povezana sa sniženim konstruktivnim ponašanjima prilikom sukoba. Važnima su se pokazale svega dvije dimenzije atribuiranja partnerovog negativnog ponašanja. Prva je stabilnost koja je izravno previđala konstruktivnu komunikaciju, ali i stav prema konstruktivnoj komunikaciji, djelujući tako i neizravno na konstruktivnu komunikaciju. Druga dimenzija je pripisivanje krivnje partneru za njegovo negativno ponašanje, koja nije izravno djelovala na konstruktivnu komunikaciju, već samo neizravno djelujući preko percipirane bihevioralne kontrole.

Možemo reći da osobe usmjerene na svoja prošla iskustva, bilo pozitivna ili negativna, imaju pozitivniji stav o konstruktivnoj komunikaciji prilikom sukoba. Pozitivniji stav o konstruktivnoj komunikaciji imaju i osobe koje smatraju da njihov partner nije postupio loše zbog nekog uzroka koji je njemu svojstven i uvijek prisutan, već vjeruju da je riječ o jednokratnom događaju. Osobe koje su svjesne i negativnih aspekata svoje prošlosti vjeruju da su sposobnije konstruktivno komunicirati prilikom sukoba, kao i osobe koje smatraju da partnera ne treba kriviti zbog njegovog negativnog postupka, te su sklone negativne događaje u svojem životu pripisivati vremenski nestabilnim uzrocima, a pozitivne uzrocima koji su uvijek prisutni, poput primjerice vlastitih osobina. Osobe pozitivnijeg stava o konstruktivnoj komunikaciji, koje vjeruju da njima bitne osobe također u situacijama sukoba komuniciraju konstruktivnu te i od njih samih očekuju da se tako ponašaju, te osobe koje vjeruju da su sposobne komunicirati konstruktivno su osobe koje učestalije planiraju konstruktivno 
komunicirati tijekom budućih sukoba u vezi. Osim važne uloge opisanih elemenata, uočeno je da osobe koje smatraju da ne mogu utjecati na ishode u svojem životu rjeđe planiraju u budućnosti komunicirati konstruktivno. Namjera konstruktivne komunikacije zaista i predviđa kasniju stvarnu konstruktivnu komunikaciju. Ovim radom potvrđena je vrijednost uključivanja dimenzija vremenskih perspektiva $\mathrm{i}$ atribucija za razumijevanje mehanizama u pozadini konstruktivne komunikacije prilikom sukoba u bliskoj vezi.

Istraživanje daje doprinos razumijevanju kognitivnih i motivacijskih činitelja kao prediktora konstruktivne komunikacije prilikom sukoba u intimnoj vezi, posebno u segmentu njihova međuodnosa. Navedeno predstavlja preduvjet boljoj integraciji ovih varijabli u postojeći modele Teorije planiranog ponašanja, a, posredno, i potpunijem shvaćanju kompleksnosti obrazaca komunikacije prilikom sukoba te učinkovitijem planiranju intervencija namijenjenih poboljšanju partnerskih odnosa. 


\section{LITERATURA}

Abramson, L. Y., Seligman, M. E. P. i Teasdale, J. D. (1978). Learned helplessness in humans: critique and reformulation. Journal of Abnormal Psychology, 87(1), 49-74.

Ajzen, I. (1991). The theory of planned behavior. Organizational Behavior and Human Decision Processes, 50(2), 179-211. http://dx.doi.org/10.1016/0749-5978(91)90020-T

Ajzen, I. (2011). Constructing a theory of planned behaviour questionnaire, preuzeto 28.12.2017. s http://people.umass.edu/aizen/pdf/tpb.measurement.pdf.

Ajzen, I. i Cote, N.G. (2008). Attitudes and the Prediction of Behavior. U W. D. Crano i R. Prislin (ur.). Attitudes and attitude change (str. 289- 311). New York: Psychology Press.

Ajzen, I. i Fishbein, M. (1977). Attitude- Behavior Relations: A theoretical analysis and review of empiricle research. Psychological Bulletin, 84, 888-918.

Ajzen, I. i Fishbein, M. (1980). Understanding attitudes and predicting social behavior. Englewood-Cliffs, NJ: Prentice- Hall.

Ajzen, I. i Fishbein, M. (2005). The Influence of Attitudes on Behavior. U D. Albarracín, B. T. Johnson i M. P. Zanna (ur.), The handbook of attitudes (str. 173-221). Mahwah, NJ, US: Lawrence Erlbaum Associates Publishers.

Ajzen, I. i Madden, T. J. (1986). Prediction of goal directed behavior: Attitudes, intentions, and perceived behavioral control. Journal of Experimental Social Psychology, 22, 453-474.

Akirmak, U., Alhan, S., Femir, B., Ince, B. i Tezcan, S. (2012). How is time perspective related to individual's perceptions of self and of interpersonal relationships? U M. P. Paixão, V. E. C. Ortuño, P. Cordeiro i R. David (ur.). First International Conference on Time Perspective: Converging Paths in Psychology, Time Theory and Research, Book of Abstracts. University of Coimbra, Portugal.

Anderson, C. A. (1991). How people think about causes: Examination of the typical phenomenal organization of attributions for success and failure. Social Cognition, 9(4), 295-329. 
Anderson, C. A. i Riger, A. L. (1991). A controllability attributional model of problems in living: Dimensional and situational interactions in the prediction of depression and loneliness. Social Cognition, 9(2), 149-181.

Anderson, C. A. i Slusher, M. P. (1986). Relocating motivational effects: A synthesis of cognitive and motivational effects on attributions for success and failure. Social Cognition, 4(3), 270-292.

Anderson, J. C. i Gerbing, D. W. (1984). The effect of sampling error on convergence, improper solutions, and goodness-of-fit indices for maximum likelihood confirmatory factor analysis. Psychometrika, 49, 155-172.

Armitage, C. J. i Conner, M. (2001). Efficacy of the theory of planned behaviour: A metaanalytic review. British Journal of Social Psychology, 40, 471-499.

Aronson, E., Wilson, T. D. i Akert, R. M. (2005). Socijalna psihologija. Zagreb: Mate.

Bandura, A. (1997). Self-efficacy: The exercise of control. New York: Freeman.

Bansal, H. S. i Taylor, S. F. (2002). Investigating interactive effects in the theory of planned behavior in a service-provider switching context. Psychology \& Marketing. 19, 407425.

Baucom, D. H. i Epstein, N. (1989). The role of cognitive variables in the assessment and treatment of marital discord. U M. Hersen, R. M. Eisler, i P. M. Miller (ur.). Progress in behavior modification, 24 (str. 223-248). Newbury Park: Sage.

Beach, S. R. H., Fincham, F. D. i Katz, J. (1998). Marital therapy in the treatment of depression: toward a third generation of therapy and research. Clinical Psychology Review, 18, 635661.

Benson, L., Mcginn, M. \& Christensen, A. (2012). Common Principles of Couple Therapy. Behavior therapy, 43, 25-35. 10.1016/j.beth.2010.12.009.

Bentler, P.M. (1989). Causal modeling via structural equation systems. U J. R. Nesselroade i R. B. Cattell (ur.), Handbook of Multivariate Experimental Psychology: Perspectives on Individual Differences. 2nd ed. (str. 317-335). New York, NY: Plenum Press. 
Bienvenu, M. J. (1971). An Interpersonal communication inventory. The Journal of Communication, 21, 381- 388.

Bodenmann, G., Kaiser, A., Hahlweg, K. i Fehm-Wolfsdorf, G. (1998). Communication patterns during marital conflict: A cross-cultural replication. Personal Relationships, 5, 343-356.

Boehnke, M. (2011). Gender Role Attitudes around the Globe: Egalitarian vs. Traditional Views. Asian Journal of Social Science, 39(1), 57-74.

Bollen, K. A. (1989). Structural equations with latent variables. New York: John Wiley.

Bradbury, T. N. i Fincham, F. D. (1990). Attributions in marriage: Review and critique. Psychological Bulletin, 107(1), 3-33.

Bradbury, T. N. i Fincham, F. D. (1992). Attributions and behavior in marital interaction. Journal of Personality and Social Psychology, 63(4), 613-628.

Bradbury, T. N. i Karney, B. R. (2014). Intimate relationships. New York: WW Norton.

Bradbury, T. N., Beach, S. R., Fincham, F. D. i Nelson, G. M. (1996). Attributions and behavior in functional and dysfunctional marriages. Journal of Consulting and Clinical Psychology, 64(3), 569-576.

Brkljačić, T. (2003). Razvoj modela za predviđanje davateljskog ponašanja. Neobjavljeni doktorski rad. Zagreb: Filozofski fakultet u Zagrebu.

Browne, M.W. i Cudeck, R. (1993). Alternative ways of assessing model fit. U K. A. Bollen i J. S. Long (ur.) Testing structural equation models (str. 136-162). Newbury Park, CA: Sage.

Bunjevac, T., Bokulić, M., Matić, J., Punek, J., Tomaš, T. i Vrlec, A. (2009). Zimbardov inventar vremenske perspektive. Neobjavljeni rad.

Byrne, B. M. (2001). Structural Equation Modeling with AMOS. Basic Concepts, Application, and Programming. London: Lawrence Erlbaum Associates.

Castanier, C., Deroche, T. i Woodman, T. (2013). Theory of planned behaviour and road violations: The moderating influence of perceived behavioural control. Transportation Research Part F: Traffic Psychology and Behaviour, 18,148-158. 
Cheng, H. i Furnham, A. (2003). Attributional style and self-esteem as predictors of psychological well being. Counselling Psychology Quarterly, 16(2), 121-130.

Chonody, J. M., Gabb, J., Killian, M. i Dunk- West, P. (2016). Measuring Relationship Quality in an International Study: Exploratory and Confirmatory Factor Validity. Research on Social Work Practice, 1- 11. doi.org/10.1177\%2F1049731516631120

Christensen, A. i Heavey, C. L. (1990). Gender and social structure in the demand-withdraw pattern of marital conflict. Journal of Personality and Social Psychology, 59, 73-81.

Christensen, A. i Nies, D. C. (1980). The Spouse Observation Checklist: Empirical analysis and critique. American Journal of Family Therapy, 8(2), 69-79.

Christensen, A. i Shenk (1991). Communication, conflict and psychological distance. Journal of Consulting and Clinical Psychology, 59 (3), 458-463.

Christensen, A. i Sullaway, M. (1984). Communication Patterns Questionnaire. Neobjavljeni rad. Los Angeles: Sveučilište California.

Conner, M. i McMillan, B. (1999). Interaction effects in the theory of planned behavior: Studying cannabis use. British Journal of Social Psychology. 38, 195-222.

Cui, M., Fincham, F. D. i Pasley, B. K. (2008). Young adult romantic relationships: the role of parents' marital problems and relationship efficacy. Personality and Social Psychology Bulletin,3 4(9), 1226- 1235. doi: 10.1177/0146167208319693.

Cutrona, C. E., Russell, D. i Jones, R. D. (1985). Cross- situational consistency in causal attributions: does attrobutional style exist? Journal of Personality and Social Psychology, 47, 1043- 1058.

Deauser, W. E. i Anderson, C. A. (1995). Controllability attributions and learned helplessness: some methodological and conceptual problems. Basic and Applied Social Psychology, 6, 297- 318.

Ding, L., Velicer,W. F. i Harlow, L. L. (1995). Effects of estimation methods, number of indicators per factor, and improper solution on structural equation modeling fit indices. Structural Equation Modeling, 2, 119-144. 
Doss, B. D., Simpson, L. E. i Christensen, A. (2004). Why do couples seek marital therapy? Professional Psychology: Research and Practice, 35(6), 608-614.

Državni zavod za statistiku (2017). Članak povodom Dana žena 2017. Preuzeto 05.08.2019. s https://www.dzs.hr/Hrv/important/Interesting/Dan_Zena/index.html.

Eldridge, K. A., Sevier, M. C., Jones, D., Atkins, C. i Christensen, A. (2007). DemandWithdraw Communication in Severely Distressed, Moderately Distressed, and Nondistressed Couples: Rigidity and Polarity During Relationship and Personal Problem Discussions. Journal of Family Psychology, 21(2), 218-226.

Fazio, R.H. (1990). Multiple processes by which attitudes guide behavior: The MODE model as an integrative framework. U M. P. Zanna (ur.). Advances in experimental social psychology, 23 (str. 75-109). San Diego: Academic Press.

Field, A. (2013). Discovering statistics using SPSS (4th edition). London: SAGE Publications Ltd.

Fincham F. D. (2003). Attributions and close relationships: From balkanization to integration. U G. J. Fletcher i M. Clark (ur.). Blackwell handbook of social psychology: Interpersonal processes. Oxford: Blackwells.

Fincham, F. D. (1985). Attribution processes in distressed and nondistressed couples: II. Responsibility for marital problems. Journal of Abnormal Psychology, 94(2), 183-190.

Fincham, F. D. (2009). Conflict, marital. U H. T. Reis i S. Sprecher (ur.). Encyclopedia of human relationships, Vol. 2. (str. 298 - 303). Los Angeles: Sage Reference Publication.

Fincham, F. D. i Bradbury, T. N. (1987). The impact of attributions in marriage: A longitudinal analysis. Journal of Personality and Social Psychology, 53(3), 510-517

Fincham, F. D. i Bradbury, T. N. (1988). The impact of attributions in marriage: An experimental analysis. Journal of Social and Clinical Psychology, 7, Special Section: Attributions (2-3), 147-162.

Fincham, F. D. i Bradbury, T. N. (1993). Marital satisfaction, depression, and attributions: A longitudinal analysis. Journal of Personality and Social Psychology, 64(3), 442-452. 
Fincham, F. D., Beach, S. R. H. i Baucom, D. H. (1987). Attribution processes in distressed and nondistressed couples: 4. Self-partner attribution differences. Journal of Personality and Social Psychology, 52(4), 739-748.

Fincham, F. D., Beach, S. R. H. i Nelson, G. (1987). Attribution processes in distressed and nondistressed couples: 3. Causal and responsibility attributions for spouse behavior. Cognitive Therapy and Research, 11(1), 71-86.

Fincham, F. i O'Leary, K. D. (1983). Causal inferences for spouse behavior in maritally distressed and nondistressed couples. Journal of Social and Clinical Psychology, 1(1), $42-57$.

Fincham, F.D. i Bradbury, T.N. (1992). Assessing attributions in marriage: The Relationship Attribution Measure. Journal of Personality and Social Psychology, 62, 457-468.

Firmin, M. W. (2010). Commentary: The seminal contribution of Richard LaPiere's attitudes vs actions (1934) research study. International Journal of Epidemiology, 39 (1), 18-20, https://doi.org/10.1093/ije/dyp401

Fishbein, M. i Ajzen, I. (1974). Attitudes towards objects as predictors of single and multiple behavioral criteria. Psychological Review, 81, 59-74.

Fletcher, G. J. O., Simpson, J. A., Campbell, L. i Overall, N. C. (2013). The science of intimate relationships. New York: Wiley-Blackwell.

Geiss, S. K. i O'Leary, K. D. (1981). Therapist ratings of frequency and severity of marital problems: implications for research. Journal of Marital and Family Therapy, 7, 515520.

George, D. i Mallery, M. (2010). SPSS for Windows Step by Step: A Simple Guide and Reference, 17.0 update (10a ed.). Boston: Pearson.

Gill, D. S., Christensen, A. i Fincham, F. D. (1999). Predicting marital satisfaction from behavior: Do all roads really lead to Rome? Personal Relationships, 6(3), 369-387.

Gjesme T. (1979). Future time orientation as a function of achivement motives, ability, delay of gratification and sex. The Journal of Psychology. 101, 173-188. 
Gollwitzer, P. M. (1993). Goal achievement: The role of intentions. U W. Stroebe i M. Hewstone (ur.), European review ofsocial psychology, 4 (str. 141-185). Chichester, UK: Wiley.

Gotlib, I. H., Lewinsohn, P. M., Seeley, J. R., Rohde, P. i Redner, J. E. (1993). Negative Cognitions and Attributional Style in Depresses Adolescents: An Examination of Stability and Specificity. Journal of abnormal psychology, 102(4), 607-615.

Gottman, J. M. (1979). Marital interaction: Experimental investigations. New York: Academic Press.

Gottman, J. M. (1994). What predicts divorce: The relationship between marital process and marital outcomes. Hillsdale, NJ: Lawrence Erlbaum.

Gottman, J. M. (1998). Psychology and the study of marital processes. Annual Review of Psychology, 49, 169-197.

Gottman, J. M. (1999). The marriage clinic: A scientifically based marital therapy. New York: W.W. Norton.

Gottman, J. M. i Levenson, R. W. (1986). Assessing the role of emotion in marriage. Behavioral Assessment, 8, $31-48$.

Gottman, J. M. i Krokoff, L. J. (1989). Marital interaction and satisfaction: A longitudinal view. Journal of Consulting and Clinical Psychology, 57(1), 47-52.

Gottman, J.M. i Levenson, R.W. (2000). The timing of divorce: Predicting when a couple will divorce over a 14-year period. Journal of Marriage and Family, 62, 737-745.

Graham, S. (1991). A review of attribution theory in achievement contexts. Educational Psychology Review, 3(1), 5-39.

Gravetter, F. i Wallnau, L. (2014). Essentials of statistics for the behavioral sciences (8th ed.). Belmont, CA: Wadsworth.

Guerrero, L. K., Andersen, P. A. i Afifi, W. A. (2001). Close encounters: Communicating in relationships. Mountain View, CA: Mayfield.

Hagger, M. S., Chatzisarantis, N. L. i Biddle, S. J. (2002). A meta-analytic review of the theories of reasoned action and planned behaviour in physical activity: predictive 
validity and the contribution of additional variables. Journal of Sport and Exercise Psychology, 24, 3-32.

Hagger, M. S., Chatzisarantis, N. L., Barkoukis, V., Wang, J., Hein, V., Pihu, M., Soos, I. i Karsai, I. (2007). Cross-cultural generalizability of the theory of planned behaviour among young people in physical activity context. Journal of Sport \& Exercise Psychology, 29, 1-19.

Harvey, P. i Martinko, M. (2010). Attribution Theory and Motivation. U N. Borkowski, (ur.), Organizational Behavior, Theory and Design in Health Care. Boston: Jones and Bartlett Publishers.

Heavey, C. L., Larson, B., Zumtobel, D. C. i Christensen, A. (1996). The communication patterns questionnaires: The reliability and validity of a constructive communication subscale. Journal of Marriage and the Family, 58, 796-800.

Heavey, C. L., Layne, C. i Christensen, A. (1993). Gender and conflict structure in marital interaction: A replication and extension. Journal of Consulting and Clinical Psychology, $61(1), 16-27$.

Holman, E. A. i Zimbardo, P. G. (2009). The social language of time: The time perspectivesocial network connection. Basic and applied social psychology, 31(2), 136-147. http://dx.doi.org/10.1080/01973530902880415

Holman, T. B. i Jarvis, M. O. (2003). Hostile, volatile, avoiding, and validating couple- conflict types: An investigation of Gottman's couple-conflict types. Personal Relationships, 10, 267-282.

Holman, T. B., Busby, D. M., Doxey, C., Loyer-Carlson, V. i Klein, D. M. (1997). The RELATionship Evaluation, Provo, UT: The Marriage Study Consortium.

Holmes, J. G. (1981). The exchange process in close relationships: Microbehavior and macromotives. U M. L. Lerner i S. Lerneer (ur.). The justice motive in social behavior (str. 261 -284). New York: Plenum Press.

Holtzworth-Munroe, A. i Jacobson, N. S. (1985). Causal attributions of married couples: When do they search for causes? What do they conclude when they do? Journal of Personality and Social Psychology, 48, 1398-1412. 
Hooper, D., Coughlan, J. i Mullen, M. R. (2008). Structural equation modelling: guidelines for determining model fit. Electronic Journal of Business Research Methods, 6 (1), 53-60.

Ilakovac, B. (2018). Ponašanje kućanstava u postupanju s otpadom od hrane. Neobjavljeni doktorski rad. Zagreb: Agronomski fakultet u Zagrebu.

Jacobson, N. S. i Margolin, G. (1979). Marital therapy: Strategies based on social learning and behavioral change principles. New York: Brunner/Mazel.

Jacobson, N. S., Follette, W. C. i Mcdonald, D. W. (1982). Reactivity to positive and negative behavior in distressed and nondistressed married couples. Journal of Consulting and Clinical Psychology, 50(5), 706- 714.

Jacobson, N. S., McDonald, D. W., Follette, W. C. i Berley, R. A. (1985). Attributional processes in distressed and nondistressed married couples. Cognitive Therapy and Research, 9, 35- 50.

Jelić, M., Kamenov, Ž. i Huić, A. (2014). Perceived spouse's affectionate and antagonistic behaviours and marital satisfaction. Društvena istraživanja: časopis za opća društvena pitanja, 123(1), 87-107.

Johnson, M. D. i Bradbury, T. N. (2015). Contributions of Social Learning Theory to the Promotion of Healthy Relationships: Asset or Liability? Journal of Family Theory \& Review, 7, 13-27.

Kalebić Maglica, B. (2010). Teorijski pristupi u ispitivanju rizičnih zdravstvenih ponašanja. Psihologijske teme, 19 (1), 71-102.

Kamenov, Ž. (1991). Neke determinante atribucija uspjeha i neuspjeha srednjoškolaca. Neobjavljeni magistarski rad. Zagreb: Odsjek za psihologiju Filozofskog fakulteta u Zagrebu.

Kamenov, Ž. (1998). Socijalna (ne)prikladnost prosudbe o uzrocima ponašanja temeljene na grupnoj pripadnosti. Neobjavljeni doktorski rad. Zagreb: Odsjek za psihologiju Filozofskog fakulteta u Zagrebu.

Kamenov, Ž. i Huić, A. (2012). Odnos privrženosti, vremenske perspektive i ponašanja u intimnoj vezi. U A. Brajša Žganec, J. Lopižić i Z. Penezić (ur.). Psihološki aspekti 
suvremene obitelji, braka i partnerstva: knjiga sažetaka (str. 59- 59). Zagreb: Hrvatsko psihološko društvo.

Karney, B. R. i Bradbury, T. N. (1995). The longitudinal course of marital quality and stability: A review of theory, methods, and research. Psychological Bulletin, 118(1), 3-34.

Kelley, H. H. (1972). Causal schemata and the attribution process. U E. E. Jones, D. E. Kanouse, H. H. Kelley, R. E. Nisbett, S. Valins, i B. Weiner, B. (ur.). Attribution: Perceiving the causes of behavior (str. 151-174). Morristown, NJ: General Learning Press.

Kelley, H. H. (1973). The processes of causal attribution. American Psychologist, 28(2), 107128.

Kelley, H. H., Berscheid, E., Christensen, A., Harvey, J. H., Huston, T. L., Levinger, L. i sur. (1983). Analyzing close relationships. U H. H. Kelley, E. Berscheid, A. Christensen, J. H. Harvey, T. L. Huston, G. Levinger, E. McClintock, L. A. Peplau. i D. R. Peterson (ur.). Close Relationships (str. 20 - 67). New York: Freeman.

Keough, K.A., Zimbardo, P.G., Boyd, J.N. (1999). Who's Smoking, Drinking, and Using Drugs? Time Perspective as a Predictor of Substance Use. Basic and Applied Social Psychology, 21(2)., 149-164.

Kidwell, B. i Jewell, R. D. (2003). The moderated influence of internal control: An examination across health related behaviors. Journal of Consumer Psychology, 13, 377-386.

Kiecolt- Glaser, J. K. i Newton, T. L. (2001). Marriage and health: his and hers. Psychological Bulletin, 127, 427- 503.

Klineberg, S. L. (1968). Future time perspective and the preference for delayed reward. Journal of Personality and Social Psvchology, 8, 253-257.

Kluwer, E. S. i Johnson, M. D. (2007). Conflict frequency and relationship quality across the transition to parenthood. Journal of Marriage and the Family, 69, 1089- 1106.

Kothandapani, V. (1971). Validation of feeling, belief, and intention to act as three components of attitude and their contribution to prediction of contraceptive behavior. Journal of Personality and Social Psychology, 19, 321-333. 
Krassner, A. M., Gartstein, M. A., Park, C., Dragan, W. Ł., Lecannelier, F. i Putnam, S. P. (2017). East-West, Collectivist-Individualist: A Cross-Cultural Examination of Temperament in Toddlers from Chile, Poland, South Korea, and the U.S. The European journal of developmental psychology, 14(4), 449-464. doi:10.1080/17405629.2016.1236722

Krznarić, T. i Kamenov, Ž. (2016). Attributions of partner's negative behavior and intimate relationship quality. Socijalna psihijatrija, 44 (4), 283-290.

Krznarić, T., Kamenov, Ž. i Huić, A. (2015). Vremenske perspektive i odnos roditelja kao prediktori stilova komunikacije u bliskim vezama. U D. Pajić (ur.), Savremeni trendovi u psihologiji 2015, knjiga sažetaka, (str. 153- 155). Novi Sad: Filozofski fakultet Univerziteta u Novom Sadu.

Krznarić, T., Huić, A. i Kamenov, Ž. (2013). Odrednice razvoja intimnih veza na prijelazu u odraslu dob. U Programski odbor (ur.), Naučno-stručni skup Savremeni trendovi u psihologiji: knjiga sažetaka, (str. 12-13). Novi Sad: Filozofski fakultet Univerziteta u Novom Sadu.

Krznarić, T., Kamenov, Ž. i Huić, A. (2013). Jesu li vremenska perspektiva i regulacijski fokus odrednice ponašanja u ljubavnoj vezi? U G. Kuterovac Jagodić, I. Erceg Jugović i A. Huić (ur.) 21. dani Ramira i Zorana Bujasa: sažeci priopćenja, (str. 158-158). Zagreb: Filozofski fakultet.

Krznarić, T., Kamenov, Ž. i Huić, A. (2017). Odnos atribucijskog stila i atribucije ponašanja partnera u intimnoj vezi. U L. Arambašić, I. Erceg, Inja i Ž. Kamenov (ur.). 23. Dani Ramira i Zorana Bujasa, knjiga sažetaka (str. 151- 151). Zagreb: Medicinska naklada d.o.o.

Kurdek, L.A. (1995). Predicting change in marital satisfaction from husbands' and wives' conflict resolution styles. Journal of Marriage and the Family, 57, 153- 164.

Lamm, H., Schmidt, R. W. i Trommsdorf, G. (1976). Sex and social class as determinants of future orientation (time perspective) in adolescents. Journal of Personality and Social Psychology, 34, 317- 326. 
Lavner, J. A., Karney, B. R. i Bradbury, T. N. (2016). Does Couples' Communication Predict Marital Satisfaction, or Does Marital Satisfaction Predict Communication?. Journal of marriage and the family, 78(3), 680-694. doi:10.1111/jomf.12301

Lavner, J. A., Karney, B. R. i Bradbury, T. N. (2016). Does Couples' Communication Predict Marital Satisfaction, or Does Marital Satisfaction Predict Communication? Journal of marriage and the family, 78(3), 680-694.

Lawrence E. i Bradbury T. N. (2007). Trajectories of change in physical aggression and marital satisfaction. Journal of Family Psychology, 21, 236-247. doi: 10.1037/08933200.21.2.236.

Lawrence, E. i Bradbury, T. N. (2007). Trajectories of change in physical aggression and marital satisfaction. Journal of Family Psychology, 21(2), 236- 247.

Little, T. D., Cunningham, W. A., Shahar, G. i Widaman, K. F. (2002). To parcel or not to parcel: Exploring the question, weighing the merits. Structural Equation Modeling, 9 (2), 151-173.

Madeira Graham, J. (2003). The role of marital attributions in the relationship between life stressors and marital quality. Neobjavljena doktorska disertacija. Austiin: Sveučilište u Texasu.

Margolin, G. (1981). Behavior exchange in happy and unhappy marriages: A family cycle perspective. Behavior Therapy, 12, 329- 343.

Margolin, G. i Wampold, B. E. (1981). Sequential analysis of conflict and accord in distressed and nondistressed marital partners. Journal of Consulting and Clinical Psychology, 49, 554- 567.

McMillan, B. i Conner, M. (2003). Applying an extended version of the theory of planned behavior to illicit drug use amongst students. Journal of Applied Social Psychology, 33, $1662-1683$.

McNulty, J. K. i Karney, B. R. (2001). Attributions in Marriage: Integrating Specific and Global Evaluations of a Relationship. Personality and Social Psychology Bulletin, 27, 943-955.

Mijoč, J. (2013). Modeliranje namjera za samozapošljavanjem studentske populacije. Neobjavljeni doktorski rad. Osijek: Ekonomski fakultet u Osijeku. 
Miller, G. E. i Bradbury, T. N. (1995). Refining the association between attributions and behavior in marital interaction. Journal of Family Psychology, 9(2), 196- 208.

Mischel, W., Shoda, Y. i Rodriguez, M. L. (1989). Delay of gratification in children. Science. 244, 933-938.

Mitchell, A. E., Castellani, A. M., Herrington, R. L., Joseph, J. I., Doss, B. D. i Snyder, D. K. (2008). Predictors of intimacy in couples' discussions of relationship injuries: An observational study. Journal of Family Psychology, 22, 21-29.

Navran, L. (1967). Communication and adjustment in marriage. Family Process, 6, 172-185.

Norton, R. (1983). Measuring marital quality: A critical look at the dependent variable. Journal of Marriage and the Family, 45,141-151.

Öner, B. (2000). Relationship satisfaction and dating experience: Factors affecting future time orientation in relationships with the opposite sex. The Journal of psychology, 134(5), 527-536. http://dx.doi.org/10.1080/00223980009598234

Öner, B. (2001). Factors predicting future time orientation for romantic relationships with the opposite sex. The Journal of psychology, 135(4), 430-438. http://dx.doi.org/10.1080/00223980109603709

Patterson, G. R. i Hops, H. (1972). Coercion, a game for two: Intervention techniques for marital conflict. U R. E. Ulrich i P. Mountjoy (ur.). The experimental analysis of social behavior (str. 424 - 440). New York: Appleton- Century- Crofts.

Pekeč, M. i Petrić, V. (2015). Marriages and births in Croatia. Državni zavod za statistiku Republike Hrvatske. Preuzeto 05.08.2019. s www.ec.europa.eu.

Peterson, C., Semmel, A., von Bayer, C., Abramson, L. Y., Metalsky, G. I. i Seligman, M. E. P. (1982). The attributional style questionnaire. Cognitive Therapy and Research, 6(3), 287-300.

Peterson, C. i Villanova, P. (1988). An Expanded Attributional Style Questionnaire. Journal of Abnormal Psychology, 97(1), 87-89.

Petrocelli J. V. (2003). Factor validation of the Consideration of Future Consequences Scale: Evidence for a short version. Journal of Social Psychology. 143 (4), 405-413. 
Podsakoff, P. M., MacKenzie, S. B., Lee, J.-Y. i Podsakoff, N. P. (2003). Common method biases in behavioral research: A critical review of the literature and recommended remedies. Journal of Applied Psychology, 88(5), 879-903.

Poehlman, T.A., Uhlman, E., Greenwald, A.G. i Banaji, M.R. (2009). Understanding and using the implicit association test: III. Meta-analysis of predictive validity. Journal of Personality and Social Psychology, 97(1), 17-41.

Povey, R., Conner, M., Sparks, P., James, R. i Shepard R. (2000). The theory of planned behavior and healthy eating: Examining additive and moderating effects of social influence variables. Psychology and Health, 14, 991-1006.

Pranjić, R. (2012). Komunikacija između partnera prilikom sukoba, rodne uloge partnera $i$ zadovoljstvo brakom. Neobjavljeni diplomski rad. Zagreb: Odsjek za psihologiju Filozofskog fakulteta u Zagrebu.

Przepiorka, A., Sobol-Kwapinska, T. i Jankowski, T. (2016). A polish short version of the Zimbardo Time Perspective Inventory. Pers. Individ. Differ. 101, 78-89. doi: 10.1016/j.paid.2016.05.047

Punek, J. (2010). Odrednice lažiranja odgovora na upitniku ličnosti u selekcijskoj situaciji: provjera jednog modela. Neobjavljeni diplomski rad. Zagreb: Odsjek za psihologiju Filozofskog fakulteta u Zagrebu.

Rabinovich, A., Morton, T. i Postmes, T. (2010). Time perspective and attitude-behaviour consistency in future-oriented behaviours. British Journal of Social Psychology, 49(1), 69-89.

Rempel, J. K., Ross, M. i Holmes, J. G. (2001). Trust and communicated attributions in close relationships. Journal of Personality and Social Psychology, 81(1), 57-64.

Rivis, A. i Sheeran, P. (2003). Descriptive Norms as an Additional Predictor in the Theory of Planned Behaviour: A Meta-Analysis. Current Psychology: A Journal for Diverse Perspectives on Diverse Psychological Issues, 22(3), 218-233. http://dx.doi.org/10.1007/s12144-003-1018-2

Roos, P. (1964). Time Reference Inventory. Austin, TX: Austin State School. 
Savin-Williams, R. i Ream, G. (2007). Prevalence and Stability of Sexual Orientation Components During Adolescence and Young Adulthood. Archives of sexual behavior, 36, 385-394. 10.1007/s10508-006-9088-5.

Seligman, M. E. P., Abramson, L. Y., Semmel, A. i von Baeyer, C. (1979). Depressive attributional style. Journal of Abnormal Psychology, 88, 242-247.

Shapiro, A.F. i Gottman, J.M. (2004). The Specific Affect Coding System. U P. Kerig i D. H. Baucom (ur.). Couple Observational Coding Systems. Mahwah, NJ: Lawrence Erlbaum.

Shu, X. (2004). Education and Gender Egalitarianism: The Case of China. Sociology of Education, 77(4), 311-336.

Simpson, J. A., and Campbell, L. (ur.). (2013). The Oxford Handbook of Close Relationships. New York, NY: Oxford University Press. doi: 10.1093/oxfordhb/9780195398694.001.0001

Sircova, A., van de Vijver, F. J. R., Osin, E., Milfont, T. L., Fieulaine, N., Kislali-Erginbilgic, A. i sur. (2014). A global look at time: A 24-country study of the equivalence of the Zimbardo Time Perspective Inventory. Sage Open, 4, 1-12. doi: $10.1177 / 2158244013515686$

Smith, D. A., Vivian, D. i O'Leary, K. D. (1990). Longitudinal prediction of marital discord from premarital expressions of affect. Journal of Consulting and Clinical Psychology, 58, 790- 798 .

Spanier, G. B. (1976). Measuring dyadic adjustment: New scales for assessing the quality of marriage and similar dyads. Journal of Marriage and the Family, 38, 15-28.

Stewart, R. A. C. (1 976). An experimental form of the Stewart personality inventory: A simplified-format measure of major personality dimensions. Perceptual and Motor Skills, 43, 813- 814.

Stolarski, M., Wojtkowska, K. i Kwiecińska, M. (2016). Time for love: Partners' time perspectives predict relationship satisfaction in romantic heterosexual couples. Time \& Society, 25(3), 552-574. https://doi.org/10.1177/0961463X15596703

Storaasli, R. D. i Markman, H. J. (1990). Relationship problems since the early stages of marriage: A longitudinal investigation. Journal of Family Psychology, 4, 80 - 98. 
Sullaway, M. i Christensen, A. (1983). Assessment of dysfunctional interaction patterns in couples. Journal of the Marriage and Family, 45, 653-650.

Sussman, R. i Gifford, R. (2019). Causality in the Theory of Planned Behavior. Personality and Social Psychology Bulletin, 45(6), 920- 933.

Sutton, S. (2002). Testing attitude-behaviour theories using non-experimental data: An examination of some hidden assumptions. European Review of Social Psychology, 13, $293-323$.

Tabachnick, B. G. i Fidell, L. S. (2013). Using multivariate statistics (6th edition). New Jersey: Pearson Education Inc.

Tatlović Vorkapić, S. (2013). Razvojna psihologija, Rani i predškolski odgoj i obrazovanje. Rijeka: Učiteljski fakultet u Rijeci.

Taylor, S. E. i Brown, J. D. (1988). Illusion and well-being: A social psychological perspective for mental health. Psychological Bulletin, 103, 193-210.

Teahan, J. E. (1958). Future time perspective, optimisrn, and academic achievement. Journal of Abnormal and Social Psvchology. 57, 379-380.

Tomić, M. (2016). Primjena teorije planiranog ponašanja u etnocentričnom kupovnom ponašanju. Neobjavljeni doktorski rad. Zagreb: Agronomski fakultet u Zagrebu.

Tonković, M. (2013). Motivacijske i situacijske odrednice lažiranja odgovora na upitnicima ličnosti u selekcijskoj situaciji. Neobjavljeni doktorski rad. Zagreb: Odsjek za psihologiju Filozofskog fakulteta u Zagrebu.

Triandis, H. C. (1993). Collectivism and Individualism as Cultural Syndromes. Cross-Cultural Research, The Journal of Comparative Social Science, 27(3-4), 155-180. https://doi.org/10.1177/106939719302700301

Trommsdorff, G., Mayer, B. i Albert, I. (2004). Dimensions of culture in intra-cultural comparisons: Individualism/collectivism and family-related values in three generations. U H. Vinken, J. Soeters i P. Ester (ur.). Comparing cultures: Dimensions of culture in a comparative perspective. International Studies in Sociology and Social Anthropology (str. 157 -154). Leiden: Brill. 
Trommsdorff, G., Mayer, B. i Albert, I. (2004). Individualism/collectivism and family-related values in three generations. U H. Vinken, J. Soeters i P. Ester (ur.), Comparing cultures: Dimensions of culture in a comparative perspective (str. 157-179). Leiden: Brill Academic Publishers.

Umeh, K. i Patel, R. (2004) .Theory of planned behavior and ecstasy use: An analysis of moderator-interactions. British Journal of Health Psychology, 9, 25-38.

Van Ittersum, K. (2012). The effect of decision makers' time perspective on intention-behavior consistency. Marketing Letters, 23(1), 263-277.

Weiner, B. (1979). A theory of motivation for some classroom experiences. Journal of Educational Psychology, 71(1), 3-25.

Weiner, B. (1983). Some methodological pitfalls in attributional research. Journal of Educational Psychology, 75, 530-543.

Weiner, B. (1985). An attributional theory of achievement motivation and emotion. Psychological Review, 92(4), 548-573.

Weiner, B. (2008). Reflections on the history of attribution theory and research. Social Psychology, 39(3), 151-156.

Weiss, R. L. (1978). The conceptualization of marriage from a behavioral perspective. U T. J. Paolino i B. S. McCrady (ur.). Marriage and marital therapy: Psychoanalytic, behavioral and systems theory perspectives (str. 165- 239). New York: Brunner Mazel.

Weiss, R. L., Hops, H. i Patterson, G. R. (1973). A framework for conceptualizing marital conflict: A technology for altering it, some data for evaluating it. U L. A. Hamerlynck, L. D. Handy i E. J. Mash (ur.). Behavior change: Methodology, Concepts and Practice, 309 - 342. Champaign, IL: Research Press.

Whitton, S. W. i Kuryluk, A. D. (2012). Relationship satisfaction and depressive symptoms in emerging adults: Cross-sectional associations and moderating effects of relationship characteristics. Journal of Family Psychology, 26(2), 226-235. http://dx.doi.org/10.1037/a0027267

Williams, L. J. i Holahan, P. J. (1994). Parsimony-based fit indices for multiple-indicator models: Do they work?. Structural Equation Modeling, 1, 161-189. 
Wolf, F. M. i Savickas, M. L. (1985). Time perspective and causal attributions for achievement. Journal of Educational Psychology, 77, 471-480.

Woods, S. B., Priest, J. B. i Roush, T. (2014). The biobehavioral family model: testing social support as an additional exogenous variable. Family Processes, 53(4), 672-685.

Worrell, F. C. i Mello, Z. R. (2007). The reliability and validity of Zimbardo Time Perspective Inventory scores in academically talented adolescents. Educ. Psychol. Meas. 67, 487504. doi: 10.1177/0013164406296985

Worrell, F. C., Mello, Z. R. i Buhl, M. (2013). Introducing English and German versions of the Adolescent Time Attitude Scale (ATAS). Assessment, 4, 496-510. doi: $10.1177 / 1073191110396202$

Worrell, F. C., Temple, E. C., McKay, M. T., Živkoviè, U., Perry, J. L., Mello, Z. R. i sur. (2016). A theoretical approach to resolving the psychometric problems associated with the Zimbardo time perspective inventory. Eur. J. Psychol. Assess. 34, 41-51. doi: $10.1027 / 1015-5759 / \mathrm{a} 000313$

Yzer, M. i van den Putte, B. (2014). Control perceptions moderate attitudinal and normative effects on intention to quit smoking. Psychology of Addictive Behaviors, 28(4),1153.

Zhang, J. W., Howell, R. T. i Bowerman, T. (2013). Validating a brief measure of the Zimbardo Time Perspective Inventory. Time Soc. 22, 391-409. doi: 10.1177/0961463X12441174

Zimbardo, P.G. i Boyd, J.N. (1999). Putting time in perspective. A valid, reliable, individualdifferences metric. Journal of Personality and Social Psychology, 77(6), 1271-1288. doi:10. 1037/0022-3514.77.6.1271 


\section{PRILOZI}

Prilog 1. Upitnik otvorenog oblika primijenjen s ciljem konstrukcije čestica za Mjeru namjere konstruktivne komunikacije prilikom sukoba.

Spol: $\quad$ M $\quad \check{Z}$

Dob:

Jeste li trenutno u romantičnoj vezi: $\quad$ DA $\quad$ NE

UPUTA: Molimo Vas da odvojite malo vremena te napišete što mislite o mogućnosti otvorene rasprava o konfliktnim temema, slobodnog i pozitivnog izražavanje emocija te zajedničkog truda oko postizanja rješenja u sukobu u intimnoj vezi. Nema točnih ili netočnih odgovora, zanima nas samo Vaše osobno mišljenje. Molimo Vas da odgovorite na postavljenja pitanja zapisujući misli koje Vam prve padnu na pamet. Svaku misao ili ideju zapišite na zasebnu liniju.

Sva pitanja odnose se na konstruktivno rješavanje sukoba koje uključuje otvorenu rasprava o konfliktnim temema, slobodno i pozitivno izražavanje emocija te zajednički trud oko postizanja rješenja u sukobu.

1) Koje bi bile prednosti kada biste Vi osobno otvoreno razgovarali o konfliktnim temama, slobodno i pozitivno izražavali emocije te se zajednički trudili oko postizanja rješenja u sukobu s partnerom? 
2) Koji bi bili nedostaci kada biste Vi osobno otvoreno razgovarali o konfliktnim temama, slobodno i pozitivno izražavali emocije te se zajednički trudili oko postizanja rješenja u sukobu s partnerom?

3) Što Vam još pada na pamet kada razmislite o tome da Vi osobno otvoreno razgovarate o konfliktnim temama, slobodno i pozitivno izražavate emocije te se zajednički trudite oko postizanja rješenja u sukobu s partnerom?

Po pitanju Vašeg ponašanja na način da otvoreno razgovarate o konfliktnim temama, slobodno i pozitivno izražavate emocije te se zajednički trudite oko postizanja rješenja u sukobu s partnerom, moguće je da postoje pojedinici ili grupe koji smatraju da biste se trebali tako ponašati ili da se ne biste trebali tako ponašati.

4) Navedite pojedince ili grupe koji bi odobravali da se tako ponašate ili koji smatraju da biste se trebali tako ponašati. 
5) Navedite pojedince ili grupe koji NE BI odobravali da se tako ponašate ili koji smatraju da se NE BISTE trebali tako ponašati.

6) Ponekad, kada nismo sigurni što učiniti, pokušamo vidjeti što drugi čine $u$ istoj situaciji. Navedite pojedince ili grupe za koje je NAJVJEROJATNIJE da će prilikom sukoba s partnerom otvoreno razgovarati o konfliktnim temama, slobodno i pozitivno izražavati emocije te se zajednički truditi oko postizanja rješenja.

7) Navedite pojedince ili grupe za koje je NAJMANJE VJEROJATNO da će prilikom sukoba s partnerom otvoreno razgovarati o konfliktnim temama, slobodno i pozitivno izražavati emocije te se zajednički truditi oko postizanja rješenja. 
8) Navedite sve faktore i okolnosti koji bi Vam olakšali ili Vas onemogućili da prilikom sukoba s partnerom otvoreno razgovarate o konfliktnim temama, slobodno i pozitivno izražavate emocije te se zajednički trudite oko postizanja rješenja.

Hvala Vam na suradnji! 
Prilog 2. Psihometrijsko funkcioniranje čestica preliminarne verzije Mjere namjere konstruktivne komunikacije prilikom sukoba u predistraživanju $(N=110)$

\begin{tabular}{|c|c|c|c|c|c|c|}
\hline & $M$ & $S D$ & 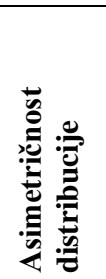 & 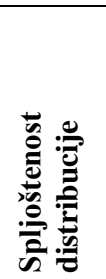 & 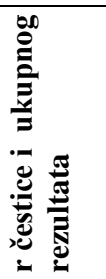 & 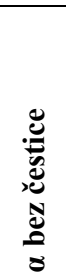 \\
\hline 1. Konstruktivno rješavanje sukoba u vezi za mene je iznimno loše/iznimno dobro. ${ }^{1}$ & 6.16 & 1.113 & -1.550 & 2.384 & .413 & .798 \\
\hline 2. Konstruktivno rješavanje sukoba u vezi za mene je sasvim bezvrijedno/iznimno vrijedno. ${ }^{1}$ & 6.41 & 1.119 & -2.945 & 10.510 & .467 & .797 \\
\hline 3. Konstruktivno rješavanje sukoba u vezi za mene je vrlo neugodno/vrlo ugodno. ${ }^{1}$ & 5.22 & 1.128 & -.130 & -.491 & .332 & .800 \\
\hline 4. Konstruktivno rješavanje sukoba u vezi za mene je dosadno/zanimljivo. ${ }^{1}$ & 5.28 & 1.182 & -.261 & -.542 & .520 & .795 \\
\hline 5. Konstruktivno rješavanje sukoba omogućit će mi da bolje razumijem svojeg/u partnera/icu. ${ }^{2}$ & 6.46 & .885 & -1.951 & 3.905 & .561 & .797 \\
\hline 6. Bolje razumjeti svojeg/u partnera/icu za mene bi bilo iznimno loše/iznimno dobro. ${ }^{3}$ & 6.50 & .821 & -1.873 & 3.607 & .621 & .796 \\
\hline 7. Konstruktivno rješavanje sukoba omogućit će da partner/ica i ja imamo kvalitetniju vezu. ${ }^{2}$ & 5.74 & 1.315 & -.930 & .282 & .617 & .792 \\
\hline 8. Imati kvalitetniju vezu s partnerom/icom za mene bi bilo iznimno loše/iznimno dobro. ${ }^{3}$ & 6.32 & 967 & -1.797 & 3.921 & .575 & .796 \\
\hline 9. Konstruktivno rješavanje sukoba omogućit će mi da se osjećam dobro u vezi sebe. ${ }^{2}$ & 6.41 & 1.095 & -2.500 & 6.565 & .517 & .796 \\
\hline 10. Osjećati se dobro u vezi sebe za mene bi bilo iznimno loše/iznimno dobro. ${ }^{3}$ & 6.10 & 1.117 & -1.570 & 2.643 & .480 & .797 \\
\hline 11. Konstruktivno rješavanje sukoba unaprijedit će našu vezu. ${ }^{2}$ & 5.49 & 1.488 & -.739 & -.280 & .453 & .796 \\
\hline 12. Unaprijediti našu vezu za mene bi bilo iznimno loše/iznimno dobro. ${ }^{3}$ & 4.59 & 1.666 & -.453 & -.705 & .064 & .808 \\
\hline 13. Konstruktivno rješavanje sukoba omogućit će da identificiramo uzrok problema u našoj vezi. ${ }^{2}$ & 5.12 & 1.432 & -.670 & -.055 & .392 & .798 \\
\hline 14. Identificirati uzrok problema u našoj vezi za mene bi bilo iznimno loše/iznimno dobro. ${ }^{3}$ & 4.84 & 1.358 & -.279 & -.478 & .262 & .802 \\
\hline 15. Konstruktivno rješavanje sukoba omogućit će da pronađemo rješenje problema u vezi. ${ }^{2}$ & 5.03 & 1.364 & -.580 & -.122 & .243 & .802 \\
\hline 16. Pronaći rješenje problema u vezi za mene bi bilo iznimno loše/iznimno dobro. ${ }^{3}$ & 5.91 & 1.193 & -.780 & -.610 & .466 & .797 \\
\hline 17. Konstruktivno rješavanje sukoba skraćuje trajanje sukoba. ${ }^{2}$ & 4.36 & 1.304 & -.049 & .277 & .305 & .801 \\
\hline 18. Skratiti trajanje sukoba za mene bi bilo iznimno loše/iznimno dobro. ${ }^{3}$ & 5.00 & 1.514 & -.629 & -.037 & .373 & .798 \\
\hline
\end{tabular}




\begin{tabular}{|c|c|c|c|c|c|c|}
\hline & M & SD & 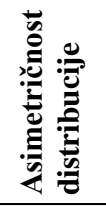 & 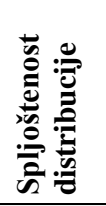 & 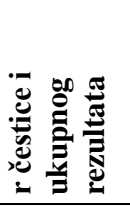 & 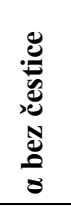 \\
\hline 19. Ukoliko bih konstruktivno rješavao/la sukob, bojao/la bih se da ću biti povrijeđen/a. ${ }^{* 2}$ & 6.24 & .938 & -1.036 & .074 & .534 & .797 \\
\hline 20. Biti povrijeđen/a za mene bi bilo iznimno loše/iznimno dobro.*3 & 5.71 & 1.546 & -1.121 & .523 & .421 & .797 \\
\hline 21. Konstruktivnim rješavanjem sukoba došlo bi do zaoštravanja odnosa s partnerom/icom.*2 & 5.22 & 1.529 & -.533 & -.393 & .512 & .794 \\
\hline 22. Zaoštravanje odnosa s partnerom/icom za mene bi bilo iznimno loše/iznimno dobro.* 3 & 5.90 & 1.270 & -1.259 & 1.457 & .517 & .795 \\
\hline 23. Konstruktivnim rješavanjem sukoba bih povrijedio/la partnera/icu. ${ }^{* 2}$ & 5.93 & 1.366 & -1.516 & 2.241 & .547 & .794 \\
\hline 24. Povrijediti partnera/icu za mene bi bilo iznimno loše/iznimno dobro. ${ }^{* 3}$ & 5.53 & 1.470 & -.991 & .778 & .553 & .793 \\
\hline 25. Konstruktivno rješavanje sukoba može dovesti do prekida veze. ${ }^{* 2}$ & 4.36 & 1.373 & -.446 & -.054 & .414 & .797 \\
\hline 26. Prekid veze za mene bi bio iznimno loš/iznimno dobar.*3 & 3.73 & 1.702 & .005 & -.931 & .003 & .811 \\
\hline 27. Većina ljudi koji su mi važni smatra da ne trebam/trebam konstruktivno rješavati sukobe u vezi. ${ }^{4}$ & 5.81 & 1.274 & -1.205 & 1.365 & .439 & .797 \\
\hline 28. Većina mojih prijatelja konstruktivno rješava sukobe u vezi. ${ }^{4}$ & 5.91 & 1.488 & -1.558 & 2.053 & .437 & .796 \\
\hline 29. Od mene se očekuje da konstruktivno rješavam sukobe u vezi. ${ }^{4}$ & 2.85 & 1.516 & .750 & -.119 & .139 & .806 \\
\hline 30. Većina ljudi čije mišljenje cijenim bi odobravala da konstruktivno rješavam sukobe u vezi. ${ }^{4}$ & 5.79 & 1.189 & -1.184 & 1.973 & .605 & .793 \\
\hline 31. MOJ/A PARTNER/ICA smatra da trebam konstruktivno rješavati sukobe u vezi. ${ }^{5}$ & 5.53 & 1.325 & -.903 & .262 & .646 & .791 \\
\hline 32. Moji MUŠKI PRIJATELJI smatraju da trebam konstruktivno rješavati sukobe u vezi. ${ }^{5}$ & 6.12 & .993 & -1.559 & 3.828 & .574 & .796 \\
\hline 33. Moje ŽENSKE PRIJATELJICE smatraju da trebam konstruktivno rješavati sukobe u vezi. ${ }^{5}$ & 3.63 & 1.876 & .124 & -1.073 & -.097 & .815 \\
\hline 34. Moji RODITELJI smatraju da trebam konstruktivno rješavati sukobe u vezi. ${ }^{5}$ & 4.71 & 1.672 & -.439 & -.644 & -.016 & .811 \\
\hline 35. Moji KOLEGE smatraju da trebam konstruktivno rješavati sukobe u vezi. ${ }^{5}$ & 2.96 & 1.786 & .636 & -.795 & -.283 & .821 \\
\hline 36. Općenito govoreći, koliko Vam je stalo do toga što Vaši MUŠKI PRIJATELJI misle da biste trebali činiti? ${ }^{6}$ & 3.60 & 1.516 & .256 & -.466 & -.173 & .815 \\
\hline $\begin{array}{l}\text { 37. Općenito govoreći, koliko Vam je stalo do toga što Vaše ŽENSKE PRIJATELJICE misle da biste trebali } \\
\text { učiniti? }^{6}\end{array}$ & 2.91 & 1.855 & .732 & -.698 & -.071 & .814 \\
\hline 38. Općenito govoreći, koliko Vam je stalo do toga što Vaši RODITELJI misle da biste trebali činiti? ${ }^{6}$ & 3.86 & 1.869 & -.150 & -1.174 & -.210 & .819 \\
\hline 39. Općenito govoreći, koliko Vam je stalo do toga što VAŠ/A PARTNER/ICA misli da biste trebali činiti? ${ }^{6}$ & 4.97 & 1.571 & -.649 & -.144 & -.036 & .811 \\
\hline
\end{tabular}


40. Općenito govoreći, koliko Vam je stalo do toga što Vaši KOLEGE misle da biste trebali činiti? ${ }^{6}$

41. Konstruktivno rješavanje sukoba u vezi za mene je iznimno teško/iznimno lako. ${ }^{7}$

42. Hoću li ili neću konstruktivno rješavati sukobe u vezi ovisi isključivo o meni. ${ }^{7}$

43. Uvjeren sam da bih mogao konstruktivno rješavati sukobe u vezi, kada bih to htio. ${ }^{7}$

44. Konstruktivno rješavanje sukoba u vezi za mene je nemoguće/moguće. ${ }^{7}$

45. Konstruktivno rješavanje sukoba u vezi u situaciji kada se razgovor odvija u prisutnosti drugih ljudi za mene bi bilo iznimno teško/iznimno lako. ${ }^{7}$

46. Namjeravam redovito konstruktivno rješavati sukobe $u$ vezi. ${ }^{8}$

47. Siguran/a sam da ću prilikom sljedećeg sukoba u vezi sukob rješavati konstruktivno. ${ }^{8}$

48. Potrudit ću se prilikom sukoba u vezi komunicirati konstruktivno. ${ }^{8}$

49. Kada ne bih imao/la dovoljno vremena da se nađem sa svojim/om partner/icom, to bi mi otežalo konstruktivno komuniciranje prilikom sukoba. ${ }^{9}$

50. Koliko često Vas manjak vremena sprječava da se nađete sa svojim/om partner/icom? ${ }^{10}$

51. Kada bi me moje emocije potpuno obuzele, to bi mi otežalo konstruktivno komuniciranje prilikom sukoba. ${ }^{9}$

52. Koliko često Vas Vaše emocije potpuno obuzmu? ${ }^{10}$

53. Kada moj/a partner/ica ne bi bio/bila voljan/a ili spreman/a na konstruktivno rješavanje sukoba, to bi mi otežalo konstruktivno komuniciranje prilikom sukoba. ${ }^{9}$

54. Koliko često Vaš/a partner/ica nije voljan/a ili spremna na konstruktivno rješavanje sukoba? ${ }^{10}$

55. Kada se ne bih znao/la konstruktivno ponašati prilikom sukoba, to bi mi otežalo konstruktivno komuniciranje prilikom sukoba. ${ }^{9}$

56. Koliko često se Vi ne znate konstruktivno ponašati prilikom sukoba? ${ }^{10}$

57. Kada bi druge osobe bile prisutne i uplitale se u sukobe između moje/g partnera/ice i mene, to bi mi otežalo konstruktivno komuniciranje prilikom sukoba. ${ }^{9}$

58. Koliko često prisutnost i uplitanje drugih osoba ometa rješavanje sukoba između Vas i Vaše/g partnera/ice? ${ }^{10}$

59. Kada bih se za vrijeme sukoba sjetio/la prošlih neuspješnih pokušaja rješavanja problema u vezi, to bi mi otežalo konstruktivno komuniciranje prilikom sukoba. ${ }^{9}$

$S D$

$3.29 \quad 1.819$

$2.73 \quad 1.444$

$1.89 \quad 1.087$

$2.01 \quad 1.230$

$2.01 \quad 1.280$

$3.15 \quad 1.660$ 
Prilog 3. Psihometrijske karakteristike čestica Mjere atribucija u vezi u predistraživanju $(N=110)$.

\begin{tabular}{|c|c|c|c|c|c|c|}
\hline & $M$ & $S D$ & 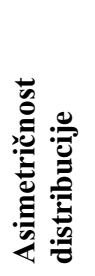 & 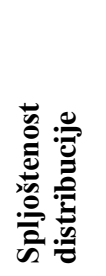 & 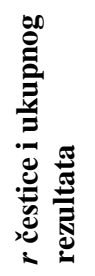 & 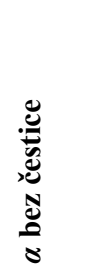 \\
\hline \multicolumn{7}{|l|}{ 1. VAŠ/A PARTNER/ICA KRITIZIRA NEŠTO ŠTO STE REKLI } \\
\hline $\begin{array}{l}\text { 1.1. Ponašanje moje/g partnera/ice je takvo zbog nje/ga same/og (npr. takav je tip osobe, njezino/njegovo } \\
\text { trenutno raspoloženje). }\end{array}$ & 4,11 & 1,448 &,- 600 &,- 524 & ,335 & ,893 \\
\hline 1.2. Ponašanje moje/g partnera/ice je takvo zbog mene (npr. kakav sam tip osobe, moje trenutno raspoloženje). & 3,28 & 1,286 & ,009 &,- 646 &,- 060 & ,899 \\
\hline 1.3. Nije vjerojatno da će se razlog zbog kojeg me partner/ica kritizirao/la promijeniti. & 3,46 & 1,346 & ,205 &,- 583 & ,314 & ,893 \\
\hline 1.4. Razlog zbog kojeg me partner/ica kritizirao/la je nešto što utječe i na druga područja naše veze. & 3,76 & 1,452 &,- 438 &,- 759 & ,295 & ,893 \\
\hline 1.5. Moj/a partner/ica me kritizirao/la namjerno, nije to napravio/la nesvjesno. & 3,48 & 1,494 &,- 184 &,- 999 & ,415 & ,891 \\
\hline 1.6. Ponašanje moje/g partnera/ice bilo je motivirano sebičnim, a ne nesebičnim razlozima. & 2,35 & 1,405 &, 819 &,- 467 &, 581 &, 888 \\
\hline 1.7. Moj/a partner/ica zaslužuje da ju/ga krivim što me kritizirala. & 2,40 & 1,308 &, 874 &, 175 &, 590 & ,888 \\
\hline \multicolumn{7}{|l|}{ 2. VAŠ/A PARTNER/ICA POČINJE PROVODITI MANJE VREMENA S VAMA } \\
\hline $\begin{array}{l}\text { 2.1. Ponašanje moje/g partnera/ice je takvo zbog nje same (npr. takav je tip osobe, njezino trenutno } \\
\text { raspoloženje). }\end{array}$ & 3,36 & 1,712 & ,075 & $-1,206$ & ,465 & ,890 \\
\hline 2.2. Ponašanje moje/g partnera/ice je takvo zbog mene (npr. kakav sam tip osobe, moje trenutno raspoloženje). & 2,75 & 1,409 & ,227 & $-1,119$ & ,377 & ,892 \\
\hline $\begin{array}{l}\text { 2.3. Nije vjerojatno da će se razlog zbog kojeg je partner/ica počeo/la provoditi manje vremena sa mnom } \\
\text { promijeniti. }\end{array}$ & 2,55 & 1,385 & 697 &,- 413 & ,563 & ,888 \\
\hline $\begin{array}{l}\text { 2.4. Razlog zbog kojeg je moj/a partner/ica počeo/la provoditi manje vremena sa mnom je nešto što utječe i na } \\
\text { druga područja naše veze. }\end{array}$ & 3,82 & 1,671 &,- 415 & $-1,069$ & ,475 & ,890 \\
\hline 2.5. Moj/a partner/ica je počeo/la provoditi manje vremena sa mnom namjerno, za razliku od nenamjerno. & 2,54 & 1,425 &, 574 &,- 639 &, 582 & ,888 \\
\hline 2.6. Ponašanje moje/g partnera/ice bilo je motivirano sebičnim, za razliku od nesebičnih pobuda. & 2,47 & 1,476 & ,726 &,- 571 & 623 &, 887 \\
\hline 2.7. Moj/a partner/ica zaslužuje da ga/ju krivim što je počeo/la provoditi manje vremena sa mnom. & 2,77 & 1,578 & ,498 &,- 833 &, 558 & ,888 \\
\hline
\end{tabular}




\begin{tabular}{|c|c|c|c|c|c|c|}
\hline & $M$ & $S D$ & 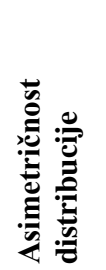 & 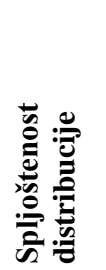 & 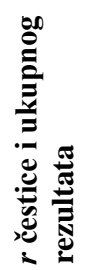 & 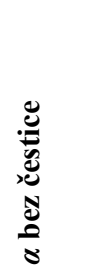 \\
\hline \multicolumn{7}{|l|}{ 3. VAŠ/A PARTNER/ICA NE OBRAĆA POZORNOST NA ONO ŠTO GOVORITE. } \\
\hline $\begin{array}{l}\text { 3.1. Ponašanje moje/g partnera/ice je takvo zbog nje/ga same/og (npr. takav je tip osobe, njezino/njegovo } \\
\text { trenutno raspoloženje). }\end{array}$ & 3,76 & 1,532 &,- 310 &,- 946 & ,494 & ,889 \\
\hline 3.2. Ponašanje moje/g partnera/ice je takvo zbog mene (npr. kakav sam tip osobe, moje trenutno raspoloženje). & 2,87 & 1,389 & ,358 &,- 573 &, 371 & ,892 \\
\hline $\begin{array}{l}\text { 3.3. Nije vjerojatno da će se razlog zbog kojeg } \mathrm{moj} / \mathrm{a} \text { partner/ica ne obraća pozornost na ono što govorim } \\
\text { promijeniti. }\end{array}$ & 2,78 & 1,535 & ,484 &,- 772 &, 552 & ,888 \\
\hline $\begin{array}{l}\text { 3.4. Razlog zbog kojeg moj/a partner/ica ne obraća pozornost na ono što govorim je nešto što utječe i na druga } \\
\text { područja naše veze. }\end{array}$ & 3,32 & 1,544 &,- 017 & $-1,221$ & ,418 & 891 \\
\hline 3.5. Moj/a partner/ica ne obraća pozornost na ono što govorim namjerno, za razliku od nenamjerno. & 2,67 & 1,478 &, 549 &,- 681 &, 585 & ,888 \\
\hline 3.6. Ponašanje moje/g partnera/ice bilo je motivirano sebičnim, za razliku od nesebičnih pobuda. & 2,60 & 1,460 &, 564 &,- 677 &, 594 & ,887 \\
\hline 3.7. Moj/a partner/ica zaslužuje da ju/ga krivim što ne obraća pozornost na ono što govorim. & 3,66 & 1,655 &,- 152 & $-1,198$ & 458 & 890 \\
\hline 4. VAŠS/A PARTNER/ICA SE DRŽI HLADNO I DISTANCIRANO & & & & & & \\
\hline $\begin{array}{l}\text { 4.1. Ponašanje moje/g partnera/ice je takvo zbog nje/ga same/og (npr. takav je tip osobe, njezino/njegovo } \\
\text { trenutno raspoloženje). }\end{array}$ & 3,50 & 1,624 &, 013 & $-1,199$ & ,404 & ,891 \\
\hline 4.2. Ponašanje moje/g partnera/ice je takvo zbog mene (npr. kakav sam tip osobe, moje trenutno raspoloženje). & 3,13 & 1,402 & ,095 &,- 944 & ,263 & ,894 \\
\hline $\begin{array}{l}\text { 4.3. Nije vjerojatno da će se razlog zbog kojeg je moj/a partner/ica hladan/a i } \\
\text { distanciran/a promijeniti. }\end{array}$ & 2,59 & 1,435 & ,677 &,- 388 &, 500 & ,889 \\
\hline $\begin{array}{l}\text { 4.4. Razlog zbog kojeg je moj/a partner/ica hladan/a i distanciran/a je nešto što utječe i na druga područja naše } \\
\text { veze. }\end{array}$ & 4,14 & 1,582 &,- 540 &,- 844 &, 508 & ,889 \\
\hline 4.5. Moj/a partner/ica je hladan/a i distanciran/a namjerno, za razliku od nenamjerno. & 2,94 & 1,510 & ,452 &,- 696 &, 404 & 891 \\
\hline 4.6. Ponašanje moje/g partnera/ice bilo je motivirano sebičnim, za razliku od nesebičnih pobuda. & 2,63 & 1,507 &, 550 &,- 823 &, 536 &, 889 \\
\hline 4.7. Moj/a partner/ica zaslužuje da ju/ga krivim što je hladan/a i distanciran/a. & 3,20 & 1,620 & ,305 & $-1,024$ & ,487 & 890 \\
\hline
\end{tabular}


Prilog 4. Psihometrijske karakteristike čestica Zimbardovog inventara vremenskih perspektiva u predistraživanju $(N=110)$.

\begin{tabular}{|c|c|c|c|c|c|c|}
\hline & $M$ & $S D$ & 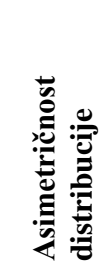 & 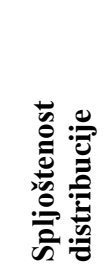 & 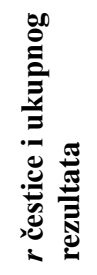 & 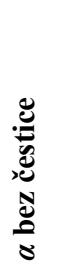 \\
\hline 1. Vjerujem da je druženje radi zabave s prijateljima jedno od važnih životnih zadovoljstava. & 4,33 & ,884 & $-1,267$ & 1,189 &, 153 &, 810 \\
\hline 2. Poznati prizori, zvukovi i mirisi iz djetinjstva često mi donose bujicu predivnih uspomena. & 3,83 & 1,096 &,- 599 &,- 658 & ,189 & ,809 \\
\hline 3. Sudbina određuje velik dio mog života. & 2,44 & 1,161 & ,221 &,- 687 & ,379 & ,804 \\
\hline 4. Često razmišljam o tome što sam sve tijekom života trebala napraviti drugačije. & 2,77 & 1,103 & ,244 &,- 577 & ,371 & ,805 \\
\hline 5. Donosim odluke uglavnom pod utjecajem osoba i stvari koje me okružuju. & 2,52 & ,996 & ,222 &,- 650 & ,202 & ,809 \\
\hline 6. Vjerujem da bi dan trebalo svakoga jutra unaprijed isplanirati. & 3,12 & 1,259 &,- 161 &,- 983 & ,061 & ,813 \\
\hline 7. Ugodno mi je razmišljati o vlastitoj prošlosti. & 3,26 & ,956 &,- 573 &, 415 &,- 077 & 815 \\
\hline 8. Ponašam se impulzivno. & 2,97 & 1,212 &,- 055 &,- 986 & ,423 & ,803 \\
\hline 9. Ne brinem se ukoliko stvari nisu obavljene na vrijeme. & 2,22 & 1,222 & ,910 &,- 169 & ,079 & ,813 \\
\hline 10. Kada nešto želim postići, točno postavim ciljeve i razmotrim kako ih mogu ostvariti. & 3,96 &, 786 &,- 544 &,- 091 & ,053 &, 812 \\
\hline 11. Sve u svemu, u mojoj prošlosti ima puno više dobrih nego loših iskustava. & 4,05 & 1,004 & $-1,062$ &, 815 &,- 281 & 820 \\
\hline 12. Dok slušam svoju omiljenu glazbu, često mi se dogodi da u potpunosti izgubim pojam o vremenu. & 3,64 & 1,197 &,- 555 &,- 800 & ,302 & ,806 \\
\hline 13. Poštivanje rokova i ispunjavanje obaveza dolazi prije zabave. & 3,57 & 1,099 &,- 508 &,- 342 &,- 028 &, 815 \\
\hline 14. Bit će što bude, bez obzira što ja radim. & 2,26 & 1,083 &, 544 &,- 237 & ,339 & ,805 \\
\hline 15. Uživam u pričama o tome kako je bilo u 'dobra stara vremena'. & 3,41 & 1,088 &,- 280 &,- 751 & ,204 &, 809 \\
\hline 16. Bolna iskustva iz prošlosti često se ponavljaju u mojim mislima. & 2,76 & 1,218 & ,365 &,- 722 & 490 &, 801 \\
\hline 17. Nastojim živjeti što potpunije, dan za danom. & 3,97 &, 806 &,- 736 & ,754 &, 105 &, 811 \\
\hline 18. Uzrujava me kada kasnim na sastanke i dogovore. & 3,75 & 1,170 &,- 717 &,- 410 & ,067 &, 813 \\
\hline 19. Kad bih mogla, živjela bih svaki dan kao da mi je posljednji. & 3,62 & 1,173 &,- 343 & $-1,061$ & ,313 &, 806 \\
\hline 20. Sjećanja na dobra vremena lako mi padaju na pamet. & 3,60 & ,960 &,- 198 &,- 904 &, 264 & 808 \\
\hline 21. Svoje obaveze prema prijateljima i nadređenima ispunjavam na vrijeme. & 4,00 & ,849 &,- 488 &,- 425 &, 031 &, 812 \\
\hline 22. U prošlosti sam bila zlostavljana i odbacivana. & 1,63 & ,997 & 1,689 & 2,061 &, 114 &, 811 \\
\hline 23. Odluke donosim kako mi dođe u tom trenutku. & 2,99 & 1,100 & ,047 &,- 543 & ,388 & ,804 \\
\hline
\end{tabular}




\begin{tabular}{|c|c|c|c|c|c|c|}
\hline & $M$ & $S D$ & 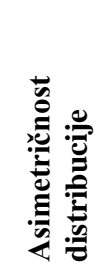 & 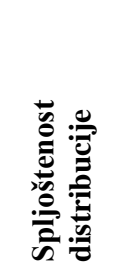 & 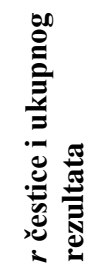 & 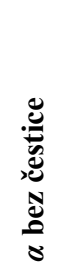 \\
\hline 24. Prihvaćam svaki dan takav kakav je, umjesto da ga pokušavam isplanirati. & 2,48 & 1,092 & 661 &,- 018 & ,164 &, 810 \\
\hline 25. Ima previše neugodnih sjećanja iz prošlosti o kojima ne volim razmišljati. & 2,24 & 1,141 & 667 &,- 468 &, 417 & ,803 \\
\hline 26. Važno mi je unijeti uzbuđenje u svoj život. & 3,78 & ,923 &,- 287 &,- 684 & ,448 & ,803 \\
\hline 27. U prošlosti sam činila greške koje bih željela poništiti. & 3,15 & 1,352 &,- 104 & $-1,208$ & ,265 & ,807 \\
\hline 28. Smatram da je važnije uživati u onome što radiš, nego to obaviti na vrijeme. & 3,31 & ,925 &,- 281 &,- 263 & ,224 & ,808 \\
\hline 29. Hvata me nostalgija za mojim djetinjstvom. & 3,09 & 1,001 &,- 099 &,- 593 & ,327 & ,806 \\
\hline 30. Prije donošenja odluke odvagnem dobre i loše strane te odluke. & 4,04 &, 811 &,- 865 & 1,318 & ,084 &, 811 \\
\hline 31. Riskiranje sprečava da mi život postane dosadan. & 3,03 & 1,034 &,- 110 &,- 569 &, 517 & ,801 \\
\hline 32. Za mene je važnije uživati u životnom putu nego se usmjeriti samo na cilj. & 3,41 & ,929 & ,102 &,- 577 & ,293 & ,807 \\
\hline 33. Stvari rijetko ispadnu onako kako sam očekivala. & 2,56 & ,963 & ,365 &,- 106 & ,335 & ,806 \\
\hline 34. Teško mi je zaboraviti neugodne prizore iz moje mladosti. & 2,44 & 1,284 & ,608 &,- 729 & ,402 &, 803 \\
\hline 35. Aktivnosti nisu toliko ugodne ako moram razmišljati o njihovim rezultatima. & 2,87 & 1,055 & ,284 &,- 501 & ,406 & ,804 \\
\hline 36. Čak i kad uživam u sadašnjosti, ne mogu izbjeći usporedbe sa sličnim iskustvima iz prošlosti. & 2,68 & 1,086 & ,092 &,- 787 & ,401 & ,804 \\
\hline 37. Nije moguće stvarno planirati budućnost jer se stvari previše mijenjaju. & 3,21 & 1,023 &,- 263 & ,219 & ,301 & ,807 \\
\hline 38. Moj životni put kontroliraju sile na koje ne mogu utjecati. & 2,20 & 1,058 & ,404 &,- 523 & ,357 & ,805 \\
\hline 39. Nema smisla brinuti oko budućnosti kad ionako ni na što ne mogu utjecati. & 1,88 & ,941 &, 787 &,- 031 & ,290 & ,807 \\
\hline 40. Završavam zadatke na vrijeme zahvaljujući svom redovitom radu. & 3,36 & 1,082 &,- 327 &,- 436 &,- 162 & ,818 \\
\hline 41. Često se isključim dok članovi moje obitelji razgovaraju o tome kako je nekad bilo. & 2,43 & 1,108 &, 542 &,- 446 & ,069 &, 812 \\
\hline 42. Volim riskirati kako bih unijela uzbuđenje u svoj život. & 2,91 & 1,184 &,- 121 &,- 840 & ,443 & ,802 \\
\hline 43. Obično radim popis stvari koje trebam obaviti. & 3,45 & 1,353 &,- 515 &,- 907 &, 087 &, 813 \\
\hline 44. Češće slijedim svoje srce nego glavu. & 3,47 & 1,091 &,- 411 &,- 462 & ,428 & ,803 \\
\hline 45. Kada imam posla koji trebam obaviti sposobna sam odoljeti iskušenjima. & 3,36 & ,976 &,- 102 &,- 401 &,- 007 &, 814 \\
\hline 46. Zna me ponijeti uzbuđenje trenutka. & 3,89 &, 835 &,- 619 &, 164 & ,332 & ,806 \\
\hline 47. Današnji način života je prekompliciran, više bi mi odgovarao jednostavniji život, kakav je bio u prošlosti. & 2,90 & 1,212 & ,229 &,- 835 & ,333 & ,805 \\
\hline
\end{tabular}




\begin{tabular}{|c|c|c|c|c|c|c|}
\hline & $M$ & $S D$ & 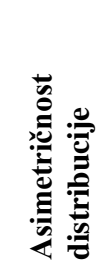 & 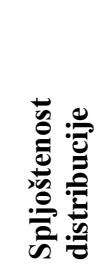 & 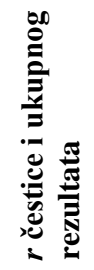 & 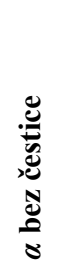 \\
\hline 48. Više mi se sviđaju moji prijatelji koji su spontani nego oni predvidljivi. & 3,57 & 1,023 &,- 357 &,- 235 & 289 & 807 \\
\hline 49. Volim obiteljske rituale i običaje koji se redovito ponavljaju. & 3,62 & 1,165 &,- 637 &,- 445 &, 141 &, 811 \\
\hline 50. Razmišljam o lošim stvarima koje su mi se dogodile u prošlosti. & 2,57 & 1,228 & ,363 &,- 901 & ,391 & ,804 \\
\hline 51. Ustrajem u teškim i dosadnim zadacima ukoliko mi to može pomoći u napredovanju. & 3,50 & 1,016 &,- 246 &,- 570 & ,043 & ,813 \\
\hline 52. Trošenje zarade na današnja zadovoljstva bolje je nego štednja za sigurnu budućnost. & 2,61 & 1,010 & ,038 &,- 530 & ,260 & ,808 \\
\hline 53. Sreća se često isplati više nego naporan rad. & 3,02 & 1,000 & ,196 &,- 375 &, 421 & ,804 \\
\hline 54. Razmišljam o dobrim stvarima koje sam propustila u svom životu. & 2,71 & 1,160 & ,267 &,- 868 & ,434 & ,803 \\
\hline 55. Volim kada su moji odnosi s bliskim osobama strastveni. & 3,89 & ,948 &,- 850 &, 681 & ,302 & ,807 \\
\hline 56. Uvijek će biti vremena da uhvatim korak s poslom. & 3,03 & 1,024 &, 142 &,- 536 &, 199 & ,809 \\
\hline
\end{tabular}


Prilog 5. Psihometrijske karakteristike čestica Upitnika komunikacijskih obrazaca prilikom sukoba u predistraživanju $(N=110)$.

\begin{tabular}{|c|c|c|c|c|c|c|}
\hline & $M$ & $S D$ & 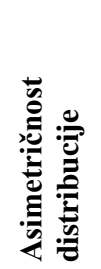 & 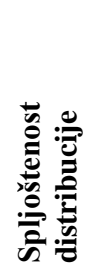 & 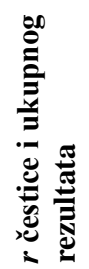 & 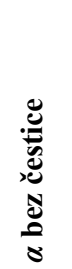 \\
\hline 1. Oba partnera izbjegavaju raspravljati o problemu. & 2,7000 & 1,84500 & 1,477 & 1,682 & ,209 & ,834 \\
\hline 2. Oba partnera pokušavaju raspravljati o problemu. & 6,4949 & 2,06711 &,- 753 &,- 459 &,- 240 & 846 \\
\hline 3. Muškarac pokušava započeti raspravu dok žena pokušava izbjeći raspravu. & 3,2525 & 2,09150 & ,777 &,- 379 & ,299 & ,832 \\
\hline 4. Žena pokušava započeti raspravu dok muškarac pokušava izbjeći raspravu. & 4,0000 & 2,26328 & ,469 &,- 589 & ,281 & ,832 \\
\hline 5. Oba partnera okrivljuju, optužuju i kritiziraju jedno drugo.* & 3,4554 & 2,14254 & ,893 &, 145 &, 544 & ,824 \\
\hline 6. Oba partnera izražavaju svoje osjećaje jedno drugome. & 6,5941 & 1,94514 &,- 623 &,- 273 &,- 037 &, 840 \\
\hline 7. Oba partnera prijete jedno drugome negativnim posljedicama.* & 2,1485 & 1,82968 & 1,805 & 2,726 & ,529 & ,826 \\
\hline 8. Oba partnera predlažu moguća rješenja i kompromise. & 6,6200 & 2,01399 &,- 728 &,- 107 &,- 316 & ,848 \\
\hline 9. Muškarac prigovara i zahtijeva dok se žena povlači, ušuti ili odbija dalje nastaviti raspravu. & 2,4300 & 1,93456 & 1,727 & 2,516 & ,442 & ,828 \\
\hline 10. Žena prigovara i zahtijeva dok se muškarac povlači, ušuti ili odbija dalje nastaviti raspravu. & 3,1100 & 2,28254 & ,892 &,- 444 &, 576 &, 822 \\
\hline 11. Muškarac kritizira, a žena se brani. & 3,2475 & 2,01199 &, 720 &,- 134 & ,477 & ,826 \\
\hline 12. Žena kritizira, a muškarac se brani. & 3,9900 & 2,08164 &, 137 &,- 788 & ,553 & ,824 \\
\hline 13. Muškarac vrši pritisak na ženu da počne ili prestane nešto činiti dok se žena tomu odupire. & 2,7576 & 1,82997 & ,928 & ,032 & ,560 & ,824 \\
\hline 14. Žena vrši pritisak na muškarca da počne ili prestane nešto činiti dok se muškarac tomu odupire. & 3,5446 & 2,36019 &, 637 &,- 634 &, 567 & ,822 \\
\hline 15. Muškarac izražava osjećaje dok žena pokušava objasniti i nudi rješenja. & 4,0792 & 2,36932 &, 263 & $-1,127$ &, 163 & ,836 \\
\hline 16. Žena izražava osjećaje dok muškarac pokušava objasniti i nudi rješenja. & 4,3400 & 2,26176 &, 106 & $-1,040$ & ,295 & ,832 \\
\hline 17. Muškarac prijeti negativnim posljedicama, a žena popušta ili odustaje. & 2,0000 & 1,66132 & 2,176 & 4,837 & ,495 &, 827 \\
\hline 18. Žena prijeti negativnim posljedicama, a muškarac popušta ili odustaje. & 2,3800 & 2,08787 & 1,640 & 1,572 & ,611 &, 822 \\
\hline
\end{tabular}




\begin{tabular}{|c|c|c|c|c|c|c|}
\hline & $M$ & $S D$ & 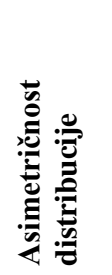 & 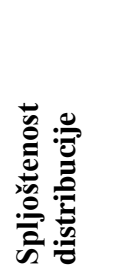 & 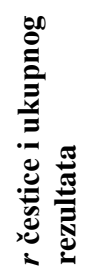 & 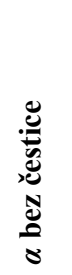 \\
\hline 19. Muškarac naziva ženu ružnim imenima, psuje ili napada njenu osobnost.* & 1,6535 & 1,38156 & 2,413 & 5,280 &, 534 & ,827 \\
\hline 20. Žena naziva muškarca ružnim imenima, psuje ili napada njegovu osobnost.* & 2,0000 & 1,68523 & 1,688 & 1,800 & ,636 &, 823 \\
\hline 21. Muškarac grubo odguruje, šamara ili udara ženu. & 1,0198 & ,19901 & 10,050 & 101,000 &, 172 &, 835 \\
\hline 22. Žena grubo odguruje, šamara ili udara muškarca. & 1,2673 &, 88194 & 3,728 & 14,162 &, 316 &, 832 \\
\hline 23. Oba partnera smatraju da je druga osoba razumjela njihovo gledište. & 6,3663 & 2,06263 &,- 444 &,- 435 &,- 451 &, 853 \\
\hline 24. Oba se partnera povlače jedno od drugoga nakon rasprave. & 2,9400 & 2,00917 & 1,052 & 196 &, 284 &, 832 \\
\hline 25. Oba partnera smatraju da je problem riješen. & 6,0990 & 2,09048 &,- 442 &,- 387 &,- 299 & ,849 \\
\hline 26. Nijedan partner ne popušta drugome nakon rasprave. & 3,1089 & 1,92822 &, 807 &,- 223 & ,249 &, 833 \\
\hline 27. Oba partnera nakon rasprave pokušavaju biti posebno pažljivi prema drugome. & 6,0505 & 2,33594 &,- 405 &,- 986 & ,008 &, 841 \\
\hline 28. Muškarac se osjeća krivim zbog onog što je rekao ili napravio dok se žena osjeća povrijeđeno. & 4,3267 & 2,58112 & 185 & $-1,345$ & ,606 &, 821 \\
\hline 29. Žena se osjeća krivom zbog onog što je rekla ili napravila dok se muškarac osjeća povrijeđeno. & 3,8812 & 2,34643 & 458 &,- 935 &, 554 &, 823 \\
\hline 30. Muškarac pokušava biti posebno pažljiv i ponaša se kao da je sve u redu dok je žena hladna. & 3,5149 & 2,40672 & ,647 &,- 815 &, 516 &, 824 \\
\hline 31. Žena pokušava biti posebno pažljiva i ponaša se kao da je sve u redu dok je muškarac hladan. & 3,0594 & 2,08241 & ,990 &, 310 & ,405 &, 828 \\
\hline 32. Muškarac zahtijeva da se žena ispriča ili obeća da će se više truditi dok se žena tomu opire. & 2,5050 & 2,09582 & 1,393 & ,703 &, 661 &, 820 \\
\hline 33. Žena zahtijeva da se muškarac ispriča ili obeća da će se više truditi dok se muškarac tomu opire. & 2,8713 & 2,23903 & 1,140 & ,338 & ,641 &, 820 \\
\hline 34. Muškarac traži podršku drugih osoba (roditelja, prijatelja...). & 2,1400 & 1,69384 & 2,003 & 4,041 &, 431 &, 828 \\
\hline 35. Žena traži podršku drugih osoba (roditelja, prijatelja...). & 3,2376 & 2,47446 & ,893 &,- 478 & ,383 &, 829 \\
\hline
\end{tabular}

Napomena: Masnim slovima otisnute su čestice koje čine subskalu konstruktivne komunikacije. Oznakom * označene su čestice subskale konstruktivne komunikacije čiji veći rezultat ukazuje na manje konstruktivne komunikacije. Kod takvih čestica, predzadnji stupac prikazuje (nespurioznu) korelaciju rekodirane čestice i ukupnog rezultata na skali. 
Prilog 6. Scree plot prikazi latentne strukture instrumenata korištenih u predistraživanju ( $N=$ $110)$.

a) Modificirani Indeks kvalitete braka

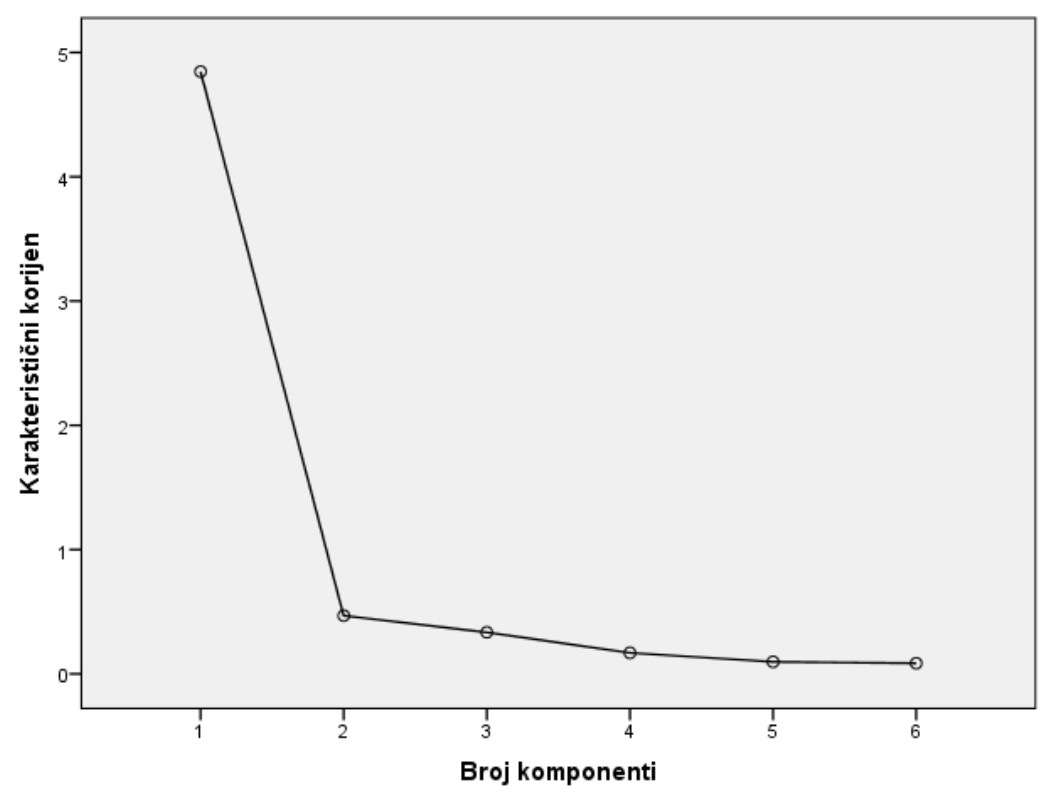

b) Mjera namjere konstruktivne komunikacije prilikom sukoba

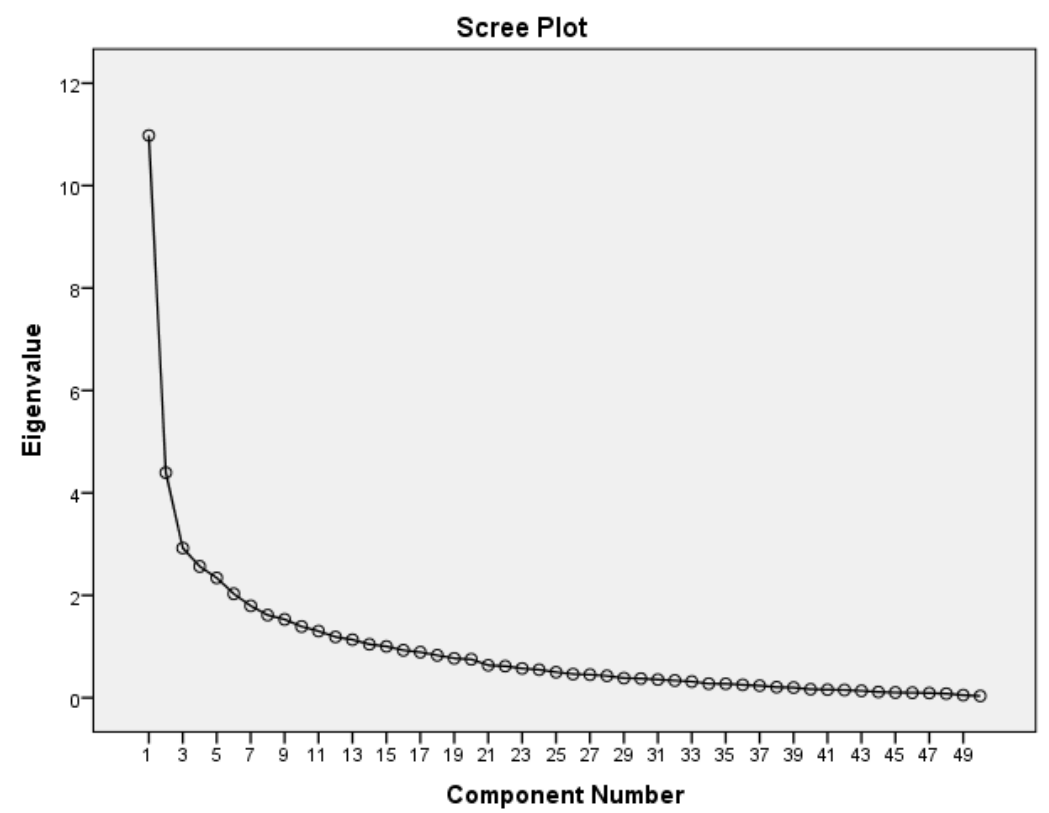


c) Mjera atribucija u vezi

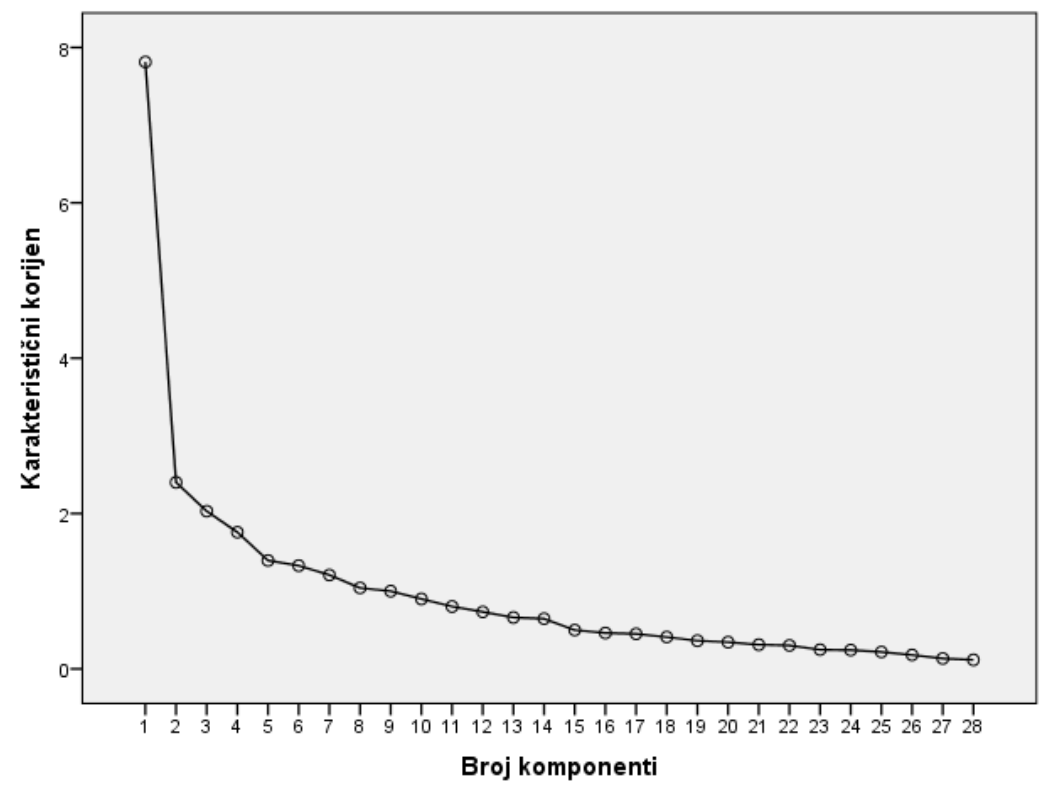

d) Zimbardov inventor vremenskih perspektiva

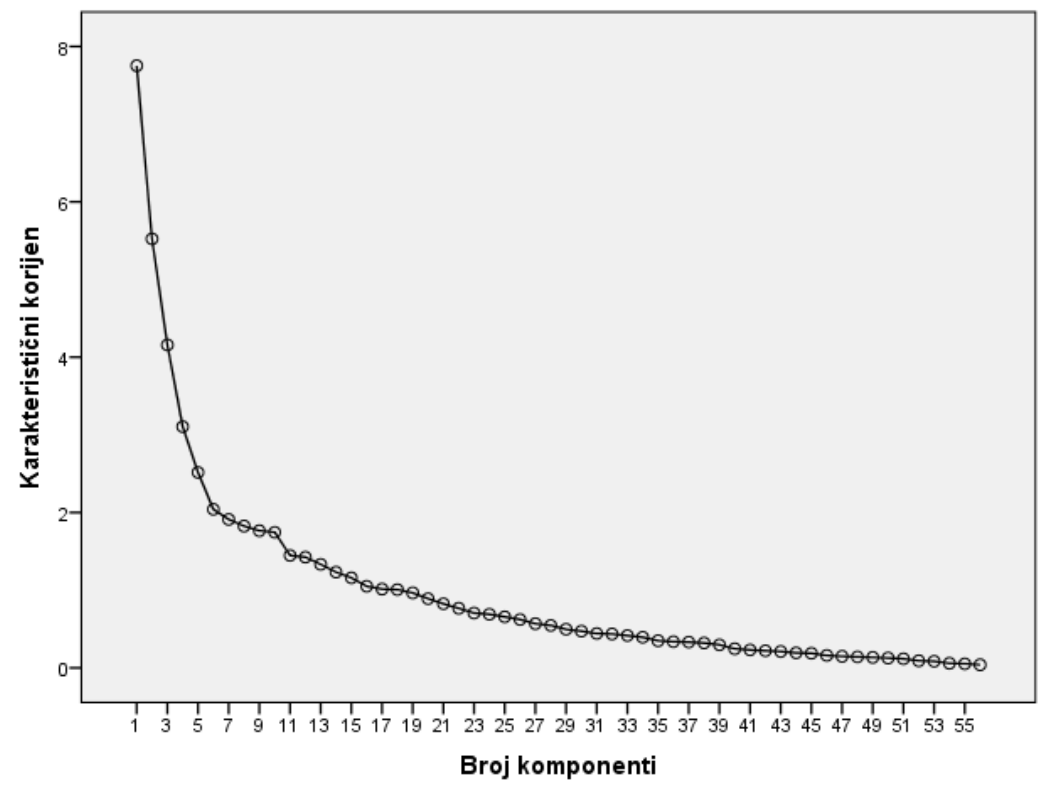


e) Skala konstruktivne komunikacije iz Upitnika komunikacijskih obrazaca prilikom sukoba

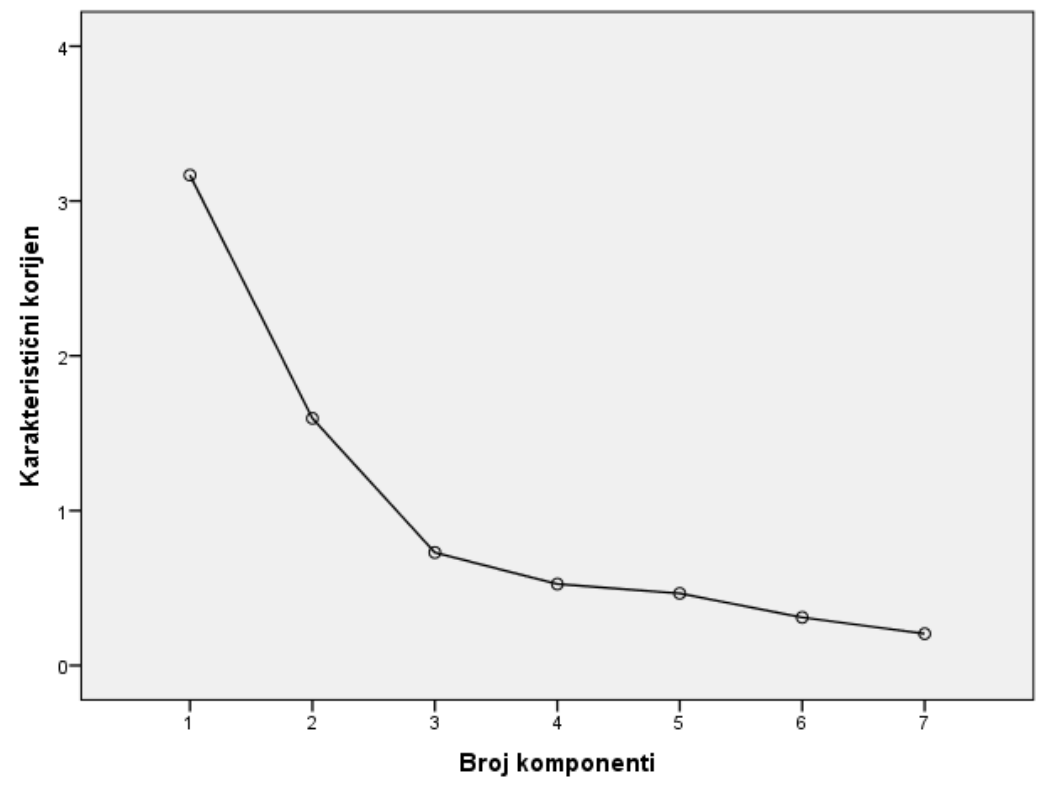




\begin{tabular}{|c|c|c|c|c|c|c|}
\hline & $M$ & $S D$ & 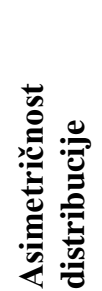 & 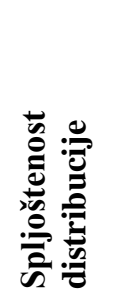 & 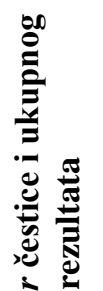 & 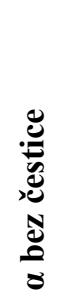 \\
\hline 1. Konstruktivno rješavanje sukoba u vezi za mene je iznimno loše/iznimno dobro. ${ }^{1}$ & 6.30 & .96 & -1.46 & 2.06 & .63 & .70 \\
\hline 2. Konstruktivno rješavanje sukoba u vezi za mene je sasvim bezvrijedno/iznimno vrijedno. ${ }^{1}$ & 6.42 & .94 & -2.2 & 6.69 & .62 & .75 \\
\hline 3. Konstruktivno rješavanje sukoba u vezi za mene je vrlo neugodno/vrlo ugodno. ${ }^{1}$ & 5.08 & 1.24 & -.25 & -.36 & .55 & .75 \\
\hline 4. Konstruktivno rješavanje sukoba u vezi za mene je dosadno/zanimljivo. ${ }^{1}$ & 5.17 & .97 & -1.02 & .76 & .55 & .73 \\
\hline 5. Konstruktivno rješavanje sukoba omogućit će mi da bolje razumijem svojeg/u partnera/icu. ${ }^{2}$ & 6.46 & .86 & -2.2 & 7.70 & .49 & .74 \\
\hline 6. Bolje razumjeti svojeg/u partnera/icu za mene bi bilo iznimno loše/iznimno dobro. ${ }^{3}$ & 5.94 & .31 & -6.08 & 44.63 & .48 & .78 \\
\hline 7. Konstruktivno rješavanje sukoba omogućit će da partner/ica i ja imamo kvalitetniju vezu. ${ }^{2}$ & 6.56 & .74 & -1.91 & 3.77 & .56 & .74 \\
\hline 8. Imati kvalitetniju vezu s partnerom/icom za mene bi bilo iznimno loše/iznimno dobro. ${ }^{3}$ & 5.91 & .34 & -4.10 & 17.33 & .53 & .77 \\
\hline 9. Konstruktivno rješavanje sukoba omogućit će mi da se osjećam dobro u vezi sebe. ${ }^{2}$ & 5.55 & .86 & -2.67 & 9.20 & .35 & .75 \\
\hline 10. Osjećati se dobro u vezi sebe za mene bi bilo iznimno loše/iznimno dobro. ${ }^{3}$ & 5.88 & .43 & -4.02 & 17.08 & .45 & .77 \\
\hline 11. Konstruktivno rješavanje sukoba unaprijedit će našu vezu. ${ }^{2}$ & 5.82 & .45 & -2.47 & 5.58 & .49 & .75 \\
\hline 12. Unaprijediti našu vezu za mene bi bilo iznimno loše/iznimno dobro. ${ }^{3}$ & 6.70 & .64 & -2.34 & 5.23 & .58 & .76 \\
\hline 13. Konstruktivno rješavanje sukoba omogućit će da identificiramo uzrok problema u našoj vezi. ${ }^{2}$ & 6.33 & .93 & -1.48 & 2.20 & .43 & .74 \\
\hline 14. Identificirati uzrok problema u našoj vezi za mene bi bilo iznimno loše/iznimno dobro. ${ }^{3}$ & 6.55 & .77 & -1.81 & 2.75 & .56 & .75 \\
\hline 15. Konstruktivno rješavanje sukoba omogućit će da pronađemo rješenje problema u vezi. ${ }^{2}$ & 6.31 & .86 & -1.05 & .20 & .48 & .74 \\
\hline 16. Pronaći rješenje problema u vezi za mene bi bilo iznimno loše/iznimno dobro. ${ }^{3}$ & 6.62 & .76 & -2.20 & 4.28 & .61 & .75 \\
\hline 17. Konstruktivno rješavanje sukoba skraćuje trajanje sukoba. ${ }^{2}$ & 5.45 & 1.57 & -.84 & -.04 & .40 & .75 \\
\hline 18. Skratiti trajanje sukoba za mene bi bilo iznimno loše/iznimno dobro. ${ }^{3}$ & 6.35 & 1.03 & -1.76 & 2.87 & .34 & .78 \\
\hline 19. Ukoliko bih konstruktivno rješavao/la sukob, bojao/la bih se da ću biti povrijeđen/a.*2 & 3.45 & 1.74 & .27 & -.86 & .30 & .77 \\
\hline
\end{tabular}


21. Konstruktivnim rješavanjem sukoba došlo bi do zaoštravanja odnosa s partnerom/icom. *2

22. Zaoštravanje odnosa s partnerom/icom za mene bi bilo iznimno loše/iznimno dobro.*3

23. Konstruktivnim rješavanjem sukoba bih povrijedio/la partnera/icu. ${ }^{* 2}$

24. Povrijediti partnera/icu za mene bi bilo iznimno loše/iznimno dobro. *3

25. Konstruktivno rješavanje sukoba može dovesti do prekida veze. ${ }^{2}$

26. Prekid veze za mene bi bio iznimno loš/iznimno dobar.*3

27. Većina ljudi koji su mi važni smatra da ne trebam/trebam konstruktivno rješavati sukobe u vezi. ${ }^{4}$

28. Većina mojih prijatelja konstruktivno rješava sukobe u vezi. ${ }^{4}$

29. Od mene se očekuje da konstruktivno rješavam sukobe u vezi. ${ }^{4}$

30. Većina ljudi čije mišljenje cijenim bi odobravala da konstruktivno rješavam sukobe u vezi. ${ }^{4}$

31. MOJ/A PARTNER/ICA smatra da trebam konstruktivno rješavati sukobe u vezi. ${ }^{5}$

32. Moji MUŠKI PRIJATELJI smatraju da trebam konstruktivno rješavati sukobe u vezi. ${ }^{5}$

33. Moje ŽENSKE PRIJATELJICE smatraju da trebam konstruktivno rješavati sukobe u vezi. ${ }^{5}$

34. Moji RODITELJI smatraju da trebam konstruktivno rješavati sukobe u vezi. ${ }^{5}$

35. Moji KOLEGE smatraju da trebam konstruktivno rješavati sukobe u vezi. ${ }^{5}$

36. Općenito govoreći, koliko Vam je stalo do toga što Vaši MUŠKI PRIJATELJI misle da biste trebali činiti? ${ }^{6}$

37. Općenito govoreći, koliko Vam je stalo do toga što Vaše ŽENSKE PRIJATELJICE misle da biste trebali učiniti? ${ }^{6}$

38. Općenito govoreći, koliko Vam je stalo do toga što Vaši RODITELJI misle da biste trebali činiti? ${ }^{6}$

39. Općenito govoreći, koliko Vam je stalo do toga što VAŠ/A PARTNER/ICA misli da biste trebali činiti? ${ }^{6}$

\begin{tabular}{|c|c|c|c|c|c|}
\hline$M$ & $S D$ & 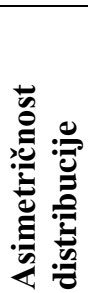 & 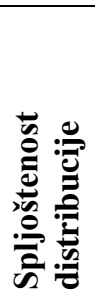 & 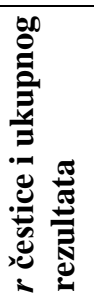 & 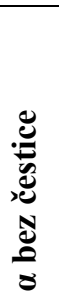 \\
\hline 2.20 & 1.18 & .88 & .67 & .33 & .79 \\
\hline 2.88 & 1.45 & .47 & -.41 & .60 & .72 \\
\hline 1.79 & 1.19 & 2.26 & 6.15 & .49 & .76 \\
\hline 3.16 & 1.53 & .23 & -.66 & .52 & .73 \\
\hline 1.43 & .86 & 3.24 & 13.83 & .53 & .76 \\
\hline 3.00 & 1.48 & .42 & -.30 & .36 & .75 \\
\hline 1.56 & .98 & 2.18 & 5.47 & .46 & .77 \\
\hline 5.69 & 1.24 & -.77 & .15 & .48 & .60 \\
\hline 4.10 & 1.20 & .08 & .42 & .37 & .67 \\
\hline 5.08 & 1.45 & -.66 & .28 & .46 & .62 \\
\hline 6.07 & 1.06 & -1.01 & .38 & .56 & .56 \\
\hline 5.70 & 1.50 & -1.08 & .46 & .44 & .81 \\
\hline 4.80 & 1.52 & -.31 & -.45 & .60 & .76 \\
\hline 5.63 & 1.33 & -.96 & .58 & .66 & .74 \\
\hline 5.68 & 1.33 & -.86 & .25 & .59 & .76 \\
\hline 5.22 & 1.46 & -.55 & -.09 & .65 & .74 \\
\hline 3.81 & 1.68 & -.04 & -.75 & .61 & .74 \\
\hline 4.20 & 1.69 & -.30 & -.87 & .74 & .69 \\
\hline 4.57 & 1.64 & -.30 & -.65 & .59 & .75 \\
\hline 6.01 & 1.05 & -1.02 & .70 & .35 & .81 \\
\hline
\end{tabular}


40. Općenito govoreći, koliko Vam je stalo do toga što Vaši KOLEGE misle da biste trebali činiti? ${ }^{6}$

41. Konstruktivno rješavanje sukoba u vezi za mene je iznimno teško/iznimno lako. ${ }^{7}$

42. Hoću li ili neću konstruktivno rješavati sukobe u vezi ovisi isključivo o meni. ${ }^{7}$

43. Uvjeren sam da bih mogao konstruktivno rješavati sukobe u vezi, kada bih to htio. ${ }^{7}$

44. Konstruktivno rješavanje sukoba u vezi za mene je nemoguće/moguće. ${ }^{7}$

45. Konstruktivno rješavanje sukoba u vezi u situaciji kada se razgovor odvija u prisutnosti drugih ljudi za mene bi bilo iznimno teško/iznimno lako. ${ }^{7}$

46. Namjeravam redovito konstruktivno rješavati sukobe $u$ vezi. ${ }^{8}$

47. Siguran/a sam da ću prilikom sljedećeg sukoba u vezi sukob rješavati konstruktivno. ${ }^{8}$

48. Potrudit ću se prilikom sukoba u vezi komunicirati konstruktivno. ${ }^{8}$

49. Kada ne bih imao/la dovoljno vremena da se nađem sa svojim/om partner/icom, to bi mi otežalo konstruktivno komuniciranje prilikom sukoba. ${ }^{9}$

50. Koliko često Vas manjak vremena sprječava da se nađete sa svojim/om partner/icom? ${ }^{10}$

51. Kada bi me moje emocije potpuno obuzele, to bi mi otežalo konstruktivno komuniciranje prilikom sukoba. ${ }^{9}$

52. Koliko često Vas Vaše emocije potpuno obuzmu? ${ }^{10}$

53. Kada moj/a partner/ica ne bi bio/bila voljan/a ili spreman/a na konstruktivno rješavanje sukoba, to bi mi otežalo konstruktivno komuniciranje prilikom sukoba. ${ }^{9}$

54. Koliko često Vaš/a partner/ica nije voljan/a ili spremna na konstruktivno rješavanje sukoba? ${ }^{10}$

55. Kada se ne bih znao/la konstruktivno ponašati prilikom sukoba, to bi mi otežalo konstruktivno komuniciranje prilikom sukoba. ${ }^{9}$

56. Koliko često se Vi ne znate konstruktivno ponašati prilikom sukoba? ${ }^{10}$

57. Kada bi druge osobe bile prisutne i uplitale se u sukobe između moje/g partnera/ice i mene, to bi mi otežalo konstruktivno komuniciranje prilikom sukoba. ${ }^{9}$

58. Koliko često prisutnost i uplitanje drugih osoba ometa rješavanje sukoba između Vas i Vaše/g partnera/ice? ${ }^{10}$

\begin{tabular}{|c|c|c|c|c|}
\hline$S D$ & 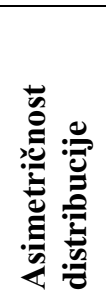 & 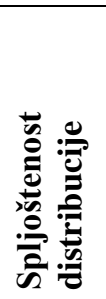 & 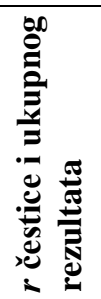 & 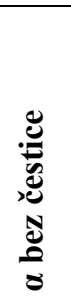 \\
\hline 1.46 & .29 & -.77 & .58 & .75 \\
\hline 1.38 & -.11 & -.45 & .42 & .43 \\
\hline 1.96 & .10 & -1.10 & .21 & .58 \\
\hline 1.30 & -.70 & -.05 & .34 & .48 \\
\hline 1.09 & -1.33 & 1.41 & .33 & .50 \\
\hline 1.69 & .57 & -.58 & .34 & .48 \\
\hline 1.31 & -.89 & .18 & .83 & .85 \\
\hline 1.32 & -.83 & .35 & .84 & .86 \\
\hline 1.11 & -1.39 & 2.34 & .80 & .89 \\
\hline 1.66 & -.89 & .05 & .42 & .64 \\
\hline 1.94 & .01 & -1.18 & .28 & .56 \\
\hline 1.63 & -.88 & .24 & .38 & .65 \\
\hline 1.70 & -.25 & -.81 & .30 & .55 \\
\hline 1.44 & -1.63 & 2.56 & .43 & .64 \\
\hline 1.88 & .45 & -.83 & .22 & .58 \\
\hline 1.25 & -1.13 & 1.47 & .19 & .69 \\
\hline 1.49 & .00 & -.64 & .40 & .51 \\
\hline 1.59 & -1.32 & 1.22 & .47 & .63 \\
\hline 1.41 & 1.13 & .70 & .27 & .56 \\
\hline
\end{tabular}




\begin{tabular}{|c|c|c|c|c|c|c|}
\hline & $M$ & $S D$ & 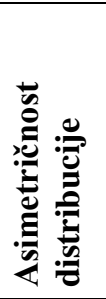 & 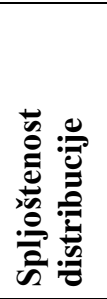 & 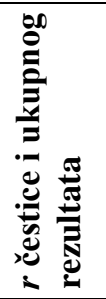 & 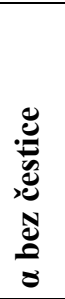 \\
\hline $\begin{array}{l}\text { 59. Kada bih se za vrijeme sukoba sjetio/la prošlih neuspješnih pokušaja rješavanja problema u vezi, to } \\
\text { bi mi otežalo konstruktivno komuniciranje prilikom sukoba. }{ }^{9}\end{array}$ & 4.15 & 1.70 & -.27 & -.81 & .39 & .65 \\
\hline 60. Koliko često se za vrijeme sukoba sjetite prošlih neuspješnih pokušaja rješavanja problema u vezi? ${ }^{10}$ & 3.53 & 1.79 & .12 & -1.07 & .39 & .51 \\
\hline $\begin{array}{l}\text { 61. Kada bih se osjećao/la umorno i pod stresom zbog svakodnevnih obveza, to bi mi otežalo } \\
\text { konstruktivno komuniciranje prilikom sukoba. }{ }^{9}\end{array}$ & 5.18 & 1.48 & -.91 & .49 & .44 & .64 \\
\hline 62. Koliko često se osjećate umorno i pod stresom zbog svakodnevnih obveza? ${ }^{10}$ & 4.83 & 1.55 & -.62 & -.08 & .28 & .55 \\
\hline $\begin{array}{l}\text { 63. Mislite li da će Vaši MUŠKI PRIJATELJI u u budućnosti komunicirati konstruktivno prilikom } \\
\text { sukoba? }{ }^{11}\end{array}$ & 4.15 & 1.22 & -.28 & .46 & .48 & .46 \\
\hline 64. Jesu li Vam Vaši MUŠKI PRIJATELJI uzor kako se treba ponašati u vezi? ${ }^{12}$ & 2.80 & 1.45 & .37 & -.72 & .42 & .39 \\
\hline $\begin{array}{l}\text { 65. Mislite li da će Vaše ŽENSKE PRIJATELJICE u budućnosti komunicirati konstruktivno prilikom } \\
\text { sukoba? }{ }^{11}\end{array}$ & 4.53 & 1.39 & -.41 & -.10 & .47 & .45 \\
\hline 66. Jesu li Vam Vaše ŽENSKE PRIJATELJICE uzor kako se treba ponašati u vezi? ${ }^{12}$ & 3.29 & 1.62 & .12 & -.97 & .46 & .36 \\
\hline $\begin{array}{l}\text { 67. Mislite li da će Vaši RODITELJI prilikom budućih međusobnih sukoba komunicirati konstruktivno? } \\
11\end{array}$ & 4.01 & 1.86 & -.10 & -.92 & .19 & .66 \\
\hline 68. Jesu li Vam Vaši RODITELJI uzor kako se treba ponašati u vezi? ${ }^{12}$ & 3.78 & 2.06 & .03 & -1.30 & .14 & .60 \\
\hline $\begin{array}{l}\text { 69. Mislite li da će VAŠ/A PARTNER/ICA u budućnosti komunicirati konstruktivno prilikom sukoba? } \\
11\end{array}$ & 5.50 & 1.22 & -1.07 & 1.53 & .31 & .55 \\
\hline 70. Je li Vam VAŠ/A PARTNER/ICA uzor kako se treba ponašati u vezi? ${ }^{12}$ & 5.45 & 1.38 & -.97 & .63 & .05 & .59 \\
\hline 71. Mislite li da će Vaši KOLEGE u budućnosti komunicirati konstruktivno prilikom sukoba? ${ }^{11}$ & 4.13 & 1.00 & -.14 & 1.80 & .39 & .52 \\
\hline 72. Jesu li Vam Vaši KOLEGE uzor kako se treba ponašati u vezi? ${ }^{12}$ & 2.80 & 1.41 & .24 & -.73 & .49 & .35 \\
\hline 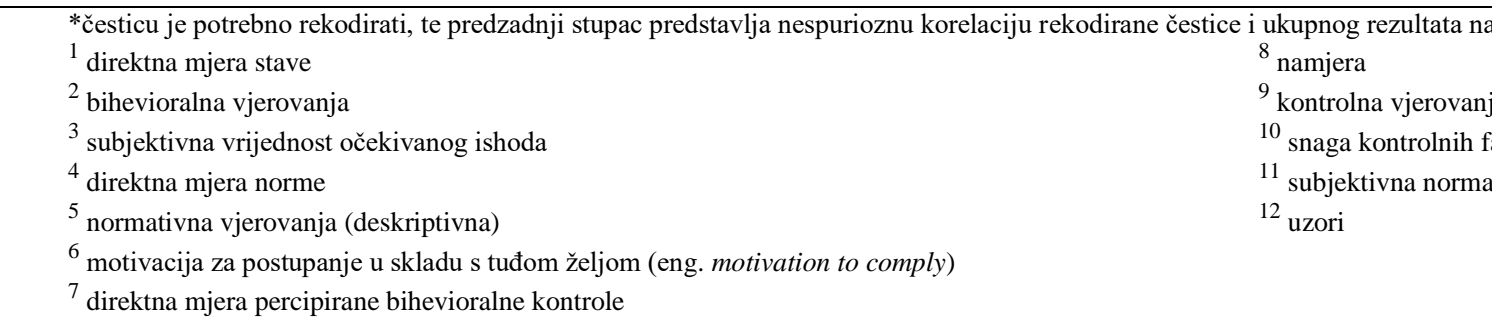 & $\begin{array}{l}\text { a skali } \\
\text { ja } \\
\text { aktora } \\
\text { (injunk }\end{array}$ & & & & & \\
\hline
\end{tabular}


Prilog $7 b$. Psihometrijsko funkcioniranje umnožaka dobivenih množenjem korespondentnih čestica preliminarne verzije Mjere namjere konstruktivne komunikacije prilikom sukoba $(N=$ 236)

\begin{tabular}{|c|c|c|c|c|c|c|c|c|}
\hline & & $\begin{array}{l}\text { Čestice koje sačinjavaju } \\
\text { umnožak }\end{array}$ & $M$ & $S D$ & 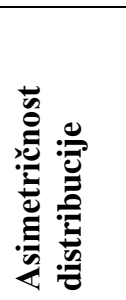 & 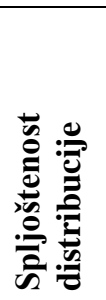 & 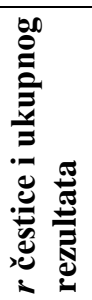 & 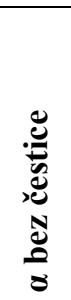 \\
\hline \multirow{11}{*}{ 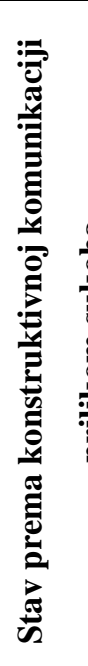 } & \multirow{11}{*}{ 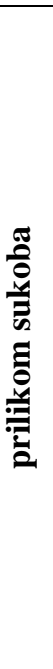 } & TPP_5 * TPP_6 & 38,5200 & 5,73840 & $-2,389$ & 8,084 &, 582 & ,802 \\
\hline & & TPP_7 * TPP_8 & 38,9226 & 5,42021 & $-2,110$ & 4,682 & ,679 & ,797 \\
\hline & & TPP_9 $*$ TPP_10 & 32,7693 & 6,02600 & $-2,256$ & 5,404 & ,437 &, 809 \\
\hline & & TPP_11*TPP_12 & 39,2893 & 5,43631 & $-2,120$ & 3,991 &, 595 &, 802 \\
\hline & & TPP_13 * TPP_14 & 42,0101 & 8,94888 & $-1,219$ &, 805 &, 577 & ,795 \\
\hline & & TPP_15* TPP_16 & 42,1572 & 8,44572 & $-1,200$ &, 742 & 624 & ,791 \\
\hline & & TPP_17*TPP_18 & 35,6910 & 12,71463 &,- 610 &,- 759 & ,438 &, 812 \\
\hline & & rec_TPP_19*rec_TPP_20 & 26,7422 & 12,10981 & ,228 &,- 751 & ,326 &, 824 \\
\hline & & rec_TPP_21*rec_TPP_22 & 32,6178 & 11,84482 &,- 320 &,- 681 &, 582 & ,793 \\
\hline & & rec_TPP_23*rec_TPP_24 & 32,0978 & 11,39507 &,- 178 &,- 662 &, 544 & ,797 \\
\hline & & rec_TPP_25*rec_TPP_26 & 32,4400 & 11,49834 &,- 347 &,- 464 & ,419 &, 812 \\
\hline \multirow{10}{*}{\multicolumn{2}{|c|}{ 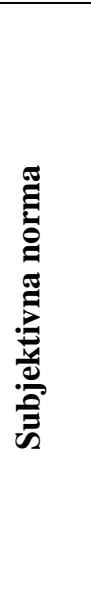 }} & TPP_31*TPP_39 & 34,4615 & 11,64090 &,- 493 &,- 514 & ,386 & 817 \\
\hline & & TPP_32* TPP_36 & 19,2241 & 11,86860 & ,633 &,- 192 & ,620 & ,746 \\
\hline & & TPP_33* TPP_37 & 24,5316 & 12,50665 &, 101 &,- 867 & ,711 &, 713 \\
\hline & & TPP_34 * TPP_38 & 26,8533 & 12,50431 &, 038 &,- 911 &, 584 &, 758 \\
\hline & & TPP_35*TPP_40 & 16,4388 & 10,05529 & ,689 &,- 124 & ,619 &, 751 \\
\hline & & TPP_63 * TPP_64 & 11,8494 & 8,06023 & 1,277 & 2,350 & ,438 & ,415 \\
\hline & & TPP_65 * TPP_66 & 15,8628 & 10,51290 & ,644 &,- 322 & ,436 & ,384 \\
\hline & & TPP_67*TPP_68 & 17,9694 & 14,24710 & ,643 &,- 692 & ,148 & ,607 \\
\hline & & TPP_69*TPP_70 & 30,6978 & 11,83470 &,- 292 &,- 580 & , 167 &, 557 \\
\hline & & TPP_71 * TPP_72 & 12,1003 & 8,10504 & 1,279 & 2,961 & ,470 &, 400 \\
\hline \multirow{7}{*}{\multicolumn{2}{|c|}{ 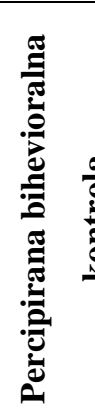 }} & TPP_49* TPP_50 & 20,7006 & 12,54786 &, 525 &,- 621 & ,345 & ,633 \\
\hline & & TPP_51*TPP_52 & 22,7021 & 12,59505 & ,207 &,- 855 & ,389 & ,618 \\
\hline & & TPP_53* TPP_54 & 19,6854 & 12,85740 &, 788 &,- 229 & ,266 & ,658 \\
\hline & & TPP_55 * TPP_56 & 19,8158 & 9,42923 &, 301 &,- 456 & ,379 & ,624 \\
\hline & & TPP_57* TPP_58 & 12,5914 & 8,96771 & 1,236 & 1,336 & ,291 & ,645 \\
\hline & & TPP_59* TPP_60 & 16,0976 & 11,91677 & ,671 &,- 354 & ,479 &, 590 \\
\hline & & TPP_61 * TPP_62 & 25,5467 & 11,89871 & ,016 &,- 754 & ,458 & ,597 \\
\hline
\end{tabular}


Prilog 7c. Formiranje paketića Mjere namjere konstruktivne komunikacije prilikom sukoba

\begin{tabular}{|c|c|c|}
\hline Konstrukt & Paketić & Umnošci čestica \\
\hline \multirow[t]{6}{*}{ Stav } & \multirow[t]{2}{*}{ TPP_P_1 } & TPP_5 * TPP_6 \\
\hline & & TPP_7 $*$ TPP_8 \\
\hline & \multirow[t]{2}{*}{ TPP_P_2 } & TPP_9 $*$ TPP_10 \\
\hline & & TPP_11 * TPP_12 \\
\hline & \multirow[t]{2}{*}{ TPP_P_3 } & TPP_13 * TPP_14 \\
\hline & & TPP_15 * TPP_16 \\
\hline \multirow[t]{6}{*}{ Subjektivna norma } & \multirow[t]{2}{*}{ TPP_P_4 } & TPP_32* TPP_36 \\
\hline & & TPP_71 * TPP_72 \\
\hline & \multirow[t]{2}{*}{ TPP_P_5 } & TPP_33 * TPP_37 \\
\hline & & TPP_65 * TPP_66 \\
\hline & \multirow[t]{2}{*}{ TPP_P_6 } & TPP_34 * TPP_38 \\
\hline & & TPP_63 * TPP_64 \\
\hline \multirow[t]{7}{*}{ Percipirana bihevioralna kontrola } & \multirow[t]{3}{*}{ TPP_P_7 } & TPP_49* TPP_50 \\
\hline & & TPP_53* TPP_54 \\
\hline & & TPP_59* TPP_60 \\
\hline & \multirow[t]{2}{*}{ TPP_P_8 } & TPP_51 * TPP_52 \\
\hline & & TPP_55 * TPP_56 \\
\hline & \multirow[t]{2}{*}{ TPP_P_9 } & TPP_57* TPP_58 \\
\hline & & TPP_61 * TPP_62 \\
\hline
\end{tabular}


Prilog 7d. Mjerni modeli direktnih mjera elemenata Mjere namjere konstruktivne komunikacije prilikom sukoba
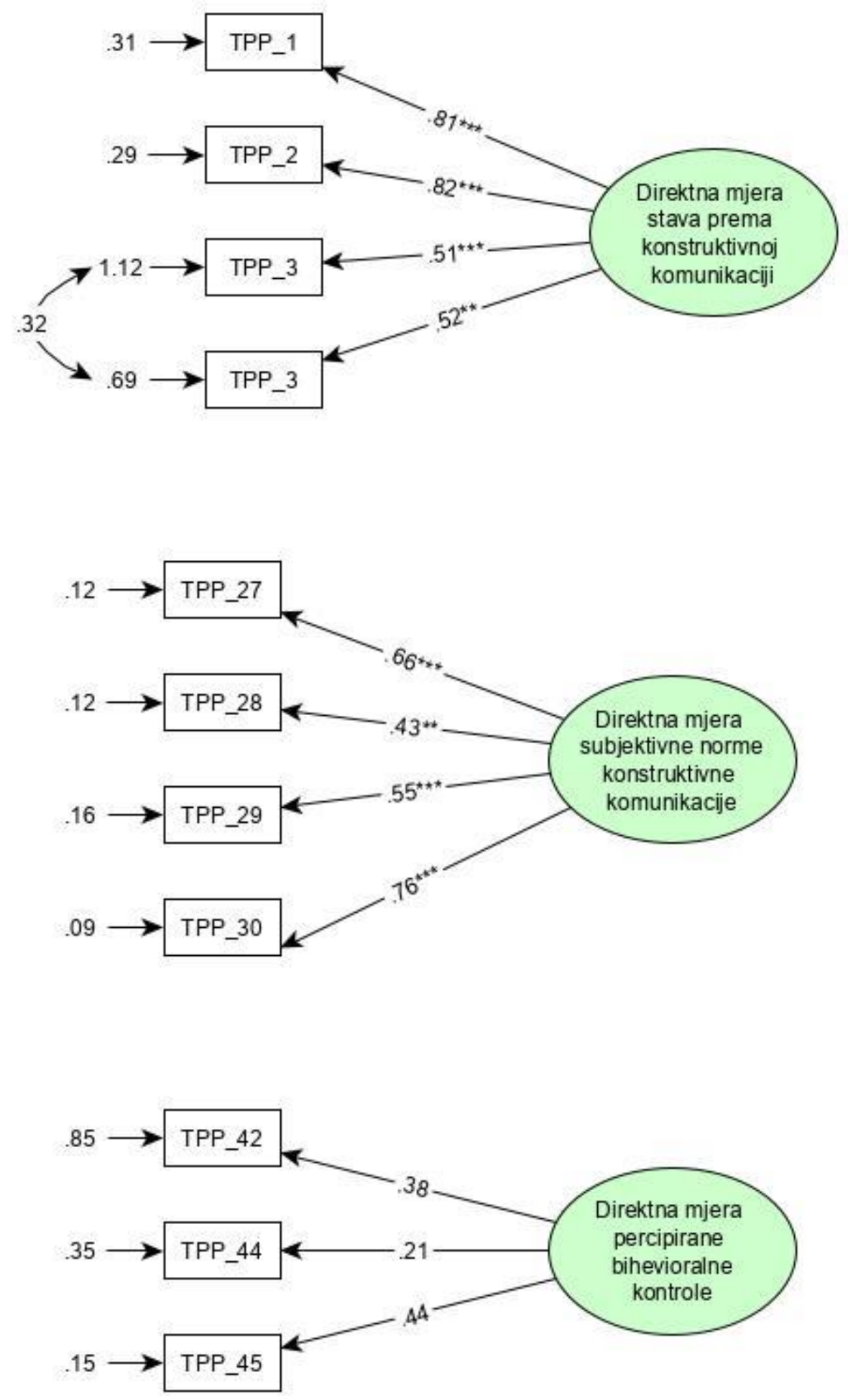
Prilog 7e. Indeksi pristajanja mjernih modela direktnih mjera stava prema konstruktivnoj komunikaciji, subjektivne norme i percipirane bihevioralne kontrole

\begin{tabular}{l|llllll}
\hline \multirow{2}{*}{ Mjerni model } & \multicolumn{5}{|c}{ Indeksi pristajanja modela podacima } \\
\cline { 2 - 7 } & $\chi^{2}(\mathrm{df})^{28}$ & $\chi^{2} / \mathrm{df}^{29}$ & $\mathrm{GFI}^{30}$ & $\mathrm{CFI}^{31}$ & RMSEA $^{32}$ & CAIC $^{33}$ \\
\hline Stav & $3.194(2)$ & 1.597 & .993 & .996 & .050 & 54.904 \\
Norma & $4.289(2)$ & 2.145 & .991 & .962 & .070 & 55.999 \\
Kontrola & $.169(1)$ & .269 & 1.000 & 1.000 & .000 & 32.488 \\
\hline
\end{tabular}

** $\mathrm{p}<0.01 ; \mathrm{p}<0.05 ; \chi^{2}$ hi-kvadrat test; df broj stupnjeva slobode; GFI indeks najboljeg pristajanja; CFI indeks komparativnog pristajanja; RMSEA prosječna standardna rezidualna pogreška; CAIC korigirani Akaikeov kriterij informacije

${ }^{28}$ neznačajan $\chi^{2}$ ukazuje na pristajanje modela podacima

${ }^{29} \chi^{2} / \mathrm{df}$ omjer manji od 2 smatra se vrlo dobrim pristajanjem modela podacima

${ }^{30}$ manji ili jednak od 1; vrijednost 1 ukazuje na savršeno pristajanje

${ }^{31}$ varira u rasponu od 0 do 1 , a što je vrijednost bliža 1 , to je bolje pristajanje

32 vrijednost ispod ,05 predstavlja odlično pristajanje podacima, vrijednost ispod ,08 prihvatljivo pristajanje (Browne i Cudeck, 1993)

33 omogućuje usporedbu modela, niža vrijednost sugerira bolje pristajanje podacima 
Prilog 8. Psihometrijske karakteristike čestica Mjere atribucija u vezi u glavnom istraživanju $(N=236)$.

\begin{tabular}{|c|c|c|c|c|c|c|}
\hline & $M$ & $S D$ & 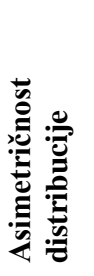 & 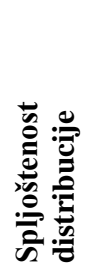 & 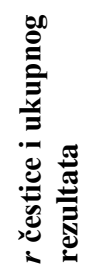 & 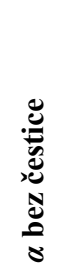 \\
\hline \multicolumn{7}{|l|}{ 1. VAŠ/A PARTNER/ICA KRITIZIRA NEŠTO ŠTO STE REKLI } \\
\hline $\begin{array}{l}\text { 1.1. Ponašanje moje/g partnera/ice je takvo zbog nje/ga same/og (npr. takav je tip osobe, njezino/njegovo } \\
\text { trenutno raspoloženje). }\end{array}$ & 4,03 & 1,30 &,- 654 &,- 072 & 238 &, 875 \\
\hline 1.2. Ponašanje moje/g partnera/ice je takvo zbog mene (npr. kakav sam tip osobe, moje trenutno raspoloženje). & 3,58 & 1,26 &,- 351 &,- 483 & , 149 & ,877 \\
\hline 1.3. Nije vjerojatno da će se razlog zbog kojeg me partner/ica kritizirao/la promijeniti. & 3,16 & 1,19 & 005 &,- 642 & ,406 &, 871 \\
\hline 1.4. Razlog zbog kojeg me partner/ica kritizirao/la je nešto što utječe i na druga područja naše veze. & 3,56 & 1,32 &,- 287 &,- 630 & ,296 & ,873 \\
\hline 1.5. Moj/a partner/ica me kritizirao/la namjerno, nije to napravio/la nesvjesno. & 3,57 & 1,44 &,- 176 &,- 807 & ,326 &, 873 \\
\hline 1.6. Ponašanje moje/g partnera/ice bilo je motivirano sebičnim, a ne nesebičnim razlozima. & 2,26 & 1,21 &, 823 &,- 071 & ,413 &, 871 \\
\hline 1.7. Moj/a partner/ica zaslužuje da ju/ga krivim što me kritizirala. & 2,23 & 1,23 & ,933 &, 312 &, 360 &, 872 \\
\hline 2. VAŠ/A PARTNER/ICA POČINJE PROVODITI MANJE VREMENA S VAMA & & & & & & \\
\hline $\begin{array}{l}\text { 2.1. Ponašanje moje/g partnera/ice je takvo zbog nje same (npr. takav je tip osobe, njezino trenutno } \\
\text { raspoloženje). }\end{array}$ & 2,98 & 1,43 & ,291 &,- 898 & ,220 &, 876 \\
\hline 2.2. Ponašanje moje/g partnera/ice je takvo zbog mene (npr. kakav sam tip osobe, moje trenutno raspoloženje). & 2,80 & 1,30 &, 354 &,- 696 & ,407 &, 871 \\
\hline $\begin{array}{l}\text { 2.3. Nije vjerojatno da će se razlog zbog kojeg je partner/ica počeo/la provoditi manje vremena sa mnom } \\
\text { promijeniti. }\end{array}$ & 2,63 & 1,30 & ,576 &,- 427 & ,319 &, 873 \\
\hline $\begin{array}{l}\text { 2.4. Razlog zbog kojeg je moj/a partner/ica počeo/la provoditi manje vremena sa mnom je nešto što utječe i na } \\
\text { druga područja naše veze. }\end{array}$ & 3,88 & 1,48 &,- 433 &,- 785 & ,484 & ,869 \\
\hline 2.5. Moj/a partner/ica je počeo/la provoditi manje vremena sa mnom namjerno, za razliku od nenamjerno. & 2,50 & 1,46 & ,761 &,- 313 &, 543 &, 867 \\
\hline 2.6. Ponašanje moje/g partnera/ice bilo je motivirano sebičnim, za razliku od nesebičnih pobuda. & 2,34 & 1,37 & ,775 &,- 378 &, 549 &, 867 \\
\hline 2.7. Moj/a partner/ica zaslužuje da ga/ju krivim što je počeo/la provoditi manje vremena sa mnom. & 2,45 & 1,48 & 837 &,- 332 & ,484 & ,869 \\
\hline
\end{tabular}




\begin{tabular}{|c|c|c|c|c|c|c|}
\hline & $M$ & $S D$ & 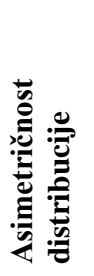 & 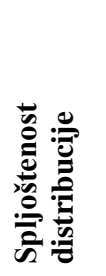 & 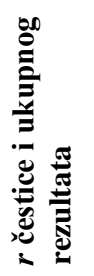 & 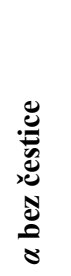 \\
\hline \multicolumn{7}{|l|}{ 3. VAŠ/A PARTNER/ICA NE OBRAĆA POZORNOST NA ONO ŠTO GOVORITE. } \\
\hline $\begin{array}{l}\text { 3.1. Ponašanje moje/g partnera/ice je takvo zbog nje/ga same/og (npr. takav je tip osobe, njezino/njegovo } \\
\text { trenutno raspoloženje). }\end{array}$ & 3,62 & 1,50 &,- 220 &,- 880 & ,258 & ,875 \\
\hline 3.2. Ponašanje moje/g partnera/ice je takvo zbog mene (npr. kakav sam tip osobe, moje trenutno raspoloženje). & 2,88 & 1,29 & ,283 &,- 751 & 339 & ,872 \\
\hline $\begin{array}{l}\text { 3.3. Nije vjerojatno da će se razlog zbog kojeg moj/a partner/ica ne obraća pozornost na ono što govorim } \\
\text { promijeniti. }\end{array}$ & 2,74 & 1,28 & ,271 &,- 908 & ,419 & 870 \\
\hline $\begin{array}{l}\text { 3.4. Razlog zbog kojeg moj/a partner/ica ne obraća pozornost na ono što govorim je nešto što utječe i na druga } \\
\text { područja naše veze. }\end{array}$ & 3,46 & 1,49 &,- 273 &,- 966 & 419 &, 870 \\
\hline 3.5. Moj/a partner/ica ne obraća pozornost na ono što govorim namjerno, za razliku od nenamjerno. & 2,46 & 1,27 & 652 &,- 275 &, 584 &, 867 \\
\hline 3.6. Ponašanje moje/g partnera/ice bilo je motivirano sebičnim, za razliku od nesebičnih pobuda. & 2,36 & 1,22 & 490 &,- 777 & 602 & ,866 \\
\hline 3.7. Moj/a partner/ica zaslužuje da ju/ga krivim što ne obraća pozornost na ono što govorim. & 2,98 & 1,46 & 276 &,- 863 &, 551 & ,867 \\
\hline 4. VAŠS/A PARTNER/ICA SE DRŽI HLADNO I DISTANCIRANO & & & & & & \\
\hline $\begin{array}{l}\text { 4.1. Ponašanje moje/g partnera/ice je takvo zbog nje/ga same/og (npr. takav je tip osobe, njezino/njegovo } \\
\text { trenutno raspoloženje). }\end{array}$ & 3,26 & 1,47 &,- 031 & $-1,037$ & ,305 & 874 \\
\hline 4.2. Ponašanje moje/g partnera/ice je takvo zbog mene (npr. kakav sam tip osobe, moje trenutno raspoloženje). & 3,23 & 1,34 &,- 136 &,- 860 & ,388 &, 871 \\
\hline $\begin{array}{l}\text { 4.3. Nije vjerojatno da će se razlog zbog kojeg je moj/a partner/ica hladan/a i } \\
\text { distanciran/a promijeniti. }\end{array}$ & 2,47 & 1,23 &, 512 &,- 645 &, 464 & ,869 \\
\hline $\begin{array}{l}\text { 4.4. Razlog zbog kojeg je moj/a partner/ica hladan/a i distanciran/a je nešto što utječe i na druga područja naše } \\
\text { veze. }\end{array}$ & 3,94 & 1,55 &,- 503 &,- 822 & 472 & 869 \\
\hline 4.5. Moj/a partner/ica je hladan/a i distanciran/a namjerno, za razliku od nenamjerno. & 3,01 & 1,52 & 255 &,- 949 &, 564 &, 866 \\
\hline 4.6. Ponašanje moje/g partnera/ice bilo je motivirano sebičnim, za razliku od nesebičnih pobuda. & 2,58 & 1,29 & ,442 &,- 579 & ,619 & ,866 \\
\hline 4.7. Moj/a partner/ica zaslužuje da ju/ga krivim što je hladan/a i distanciran/a. & 2,85 & 1,43 & ,396 &,- 749 &, 530 & ,867 \\
\hline
\end{tabular}




\begin{tabular}{|c|c|c|c|c|c|}
\hline$M$ & $S D$ & 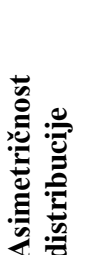 & 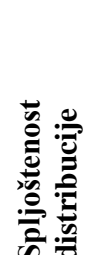 & 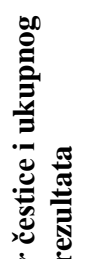 & 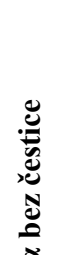 \\
\hline & & & & & \\
\hline
\end{tabular}

\begin{tabular}{|c|c|c|c|c|c|c|}
\hline \multicolumn{7}{|l|}{ 1. SUSREĆETE PRIJATELJA I ON HVALI VAŠ IZGLED. } \\
\hline 1.1. Ovisi li taj uzrok o Vama i Vašim karakteristikama ili o nekim drugim osobama i okolnostima? & 4,78 & 1,08 &,- 804 & ,803 &, 153 & 847 \\
\hline 1.2. Hoće li taj uzrok biti prisutan i u nekoj budućoj sličnoj situaciji? & 4,78 & ,91 &,- 414 & ,364 & ,319 & ,844 \\
\hline 1.3. Je li taj uzrok nešto što utječe samo na ovu situaciju ili može utjecati i na druge situacije u Vašem životu? & 4,36 & 1,30 &,- 992 & ,699 &, 350 & ,843 \\
\hline 1.4. Da Vam se dogodi ovakva situacija, koliko bi Vam bila važna? & 4,20 & 1,38 &,- 755 &,- 119 &, 267 & ,845 \\
\hline \multicolumn{7}{|l|}{ 2. VEĆ NEKO VRIJEME BEZUSPJEŠNO POKUŠAVATE NAĆI POSAO. } \\
\hline 2.1. Ovisi li taj uzrok o Vama i Vašim karakteristikama ili o nekim drugim osobama i okolnostima? & 4,06 & 1,29 &,- 143 &,- 656 &, 137 & ,848 \\
\hline 2.2. Hoće li taj uzrok biti prisutan i u nekoj budućoj sličnoj situaciji? & 4,36 & 1,17 &,- 373 &,- 259 &, 249 & 845 \\
\hline 2.3. Je li taj uzrok nešto što utječe samo na ovu situaciju ili može utjecati i na druge situacije u Vašem životu? & 4,53 & 1,25 &,- 728 & ,069 & ,431 & ,841 \\
\hline 2.4. Da Vam se dogodi ovakva situacija, koliko bi Vam bila važna? & 5,38 & ,93 & $-1,481$ & 1,579 & 477 &, 841 \\
\hline \multicolumn{7}{|l|}{ 3. POSTAJETE VRLO BOGATI. } \\
\hline 3.1. Ovisi li taj uzrok o Vama i Vašim karakteristikama ili o nekim drugim osobama i okolnostima? & 4,88 & 1,08 &,- 861 &, 858 &, 156 & ,847 \\
\hline 3.2. Hoće li taj uzrok biti prisutan i u nekoj budućoj sličnoj situaciji? & 4,83 & 1,01 &,- 706 &, 825 &, 285 &, 845 \\
\hline 3.3. Je li taj uzrok nešto što utječe samo na ovu situaciju ili može utjecati i na druge situacije u Vašem životu? & 5,08 & 1,01 &,- 993 &, 722 &, 376 &, 843 \\
\hline 3.4. Da Vam se dogodi ovakva situacija, koliko bi Vam bila važna? & 5,20 & ,97 & $-1,289$ & 1,442 & ,295 & ,844 \\
\hline
\end{tabular}

\section{DOLAZI VAM PRIJATELJ KOJI IMA PROBLEMA, A VI MU I NE POKUŠAVATE POMOĆI.}

4.1. Ovisi li taj uzrok o Vama i Vašim karakteristikama ili o nekim drugim osobama i okolnostima?

4.2. Hoće li taj uzrok biti prisutan i u nekoj budućoj sličnoj situaciji?

4.3. Je li taj uzrok nešto što utječe samo na ovu situaciju ili može utjecati i na druge situacije u Vašem životu?

4.4. Da Vam se dogodi ovakva situacija, koliko bi Vam bila važna?

$\begin{array}{llllll}4,13 & 1,74 & -, 498 & -1,053 & , 174 & , 849 \\ 3,67 & 1,47 & -, 252 & -, 793 & , 139 & , 849 \\ 3,89 & 1,54 & -, 561 & -, 642 & , 355 & , 843 \\ 5,04 & 1,04 & -, 898 & , 265 & , 303 & , 844\end{array}$




\begin{tabular}{|c|c|c|c|c|c|c|}
\hline & $M$ & $S D$ & 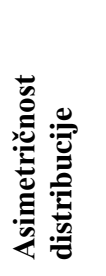 & 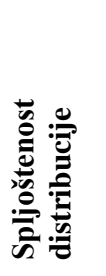 & 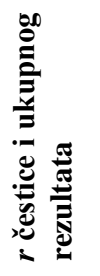 & 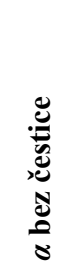 \\
\hline \multicolumn{7}{|l|}{ 5. ODRŽITE VAŽAN GOVOR PRED SKUPINOM LJUDI, A ONI NA GOVOR NEGATIVNO } \\
\hline \multicolumn{7}{|l|}{ REAGIRAJU. } \\
\hline 5.1. Ovisi li taj uzrok o Vama i Vašim karakteristikama ili o nekim drugim osobama i okolnostima? & 4,20 & 1,24 &,- 407 &,- 181 & ,220 & ,846 \\
\hline 5.2. Hoće li taj uzrok biti prisutan i u nekoj budućoj sličnoj situaciji? & 4,10 & 1,19 &,- 429 & ,193 & 324 &, 844 \\
\hline 5.3. Je li taj uzrok nešto što utječe samo na ovu situaciju ili može utjecati i na druge situacije u Vašem životu? & 4,23 & 1,40 &,- 856 & 045 & ,365 & ,843 \\
\hline 5.4. Da Vam se dogodi ovakva situacija, koliko bi Vam bila važna? & 5,14 & 1,12 & $-1,440$ & 1,917 & 447 &, 841 \\
\hline \multicolumn{7}{|l|}{ 6. RADITE NA PROJEKTU KOJI JE VRLO DOBRO OCIJENJEN. } \\
\hline 6.1. Ovisi li taj uzrok o Vama i Vašim karakteristikama ili o nekim drugim osobama i okolnostima? & 5,03 & ,90 &,- 452 &,- 651 & 143 &, 847 \\
\hline 6.2. Hoće li taj uzrok biti prisutan i u nekoj budućoj sličnoj situaciji? & 5,07 &, 82 &,- 315 &,- 958 & ,307 & ,844 \\
\hline 6.3. Je li taj uzrok nešto što utječe samo na ovu situaciju ili može utjecati i na druge situacije u Vašem životu? & 4,97 & ,99 & $-1,210$ & 2,090 & ,363 & ,843 \\
\hline 6.4. Da Vam se dogodi ovakva situacija, koliko bi Vam bila važna? & 5,60 &, 75 & $-1,990$ & 3,716 & 357 &, 844 \\
\hline \multicolumn{7}{|l|}{ 7. SUSREĆETE PRIJATELJA KOJI SE PREMA VAMA NEPRIJATELJSKI ODNOSI. } \\
\hline 7.1. Ovisi li taj uzrok o Vama i Vašim karakteristikama ili o nekim drugim osobama i okolnostima? & 3,23 & 1,27 &, 113 &,- 479 & 147 &, 848 \\
\hline 7.2. Hoće li taj uzrok biti prisutan i u nekoj budućoj sličnoj situaciji? & 3,95 & 1,23 &,- 456 &,- 111 & 359 & ,843 \\
\hline 7.3. Je li taj uzrok nešto što utječe samo na ovu situaciju ili može utjecati i na druge situacije u Vašem životu? & 3,77 & 1,38 &,- 565 &,- 481 & 429 &, 841 \\
\hline 7.4. Da Vam se dogodi ovakva situacija, koliko bi Vam bila važna? & 4,61 & 1,38 &,- 932 &, 237 & 352 & ,843 \\
\hline \multicolumn{7}{|l|}{ 8. NE USPIJEVATE OBAVITI SAV POSAO KOJI OKOLINA OČEKUJE DA ĆETE OBAVITI. } \\
\hline 8.1. Ovisi li taj uzrok o Vama i Vašim karakteristikama ili o nekim drugim osobama i okolnostima? & 4,62 & 1,18 &,- 654 & 083 & 263 & ,845 \\
\hline 8.2. Hoće li taj uzrok biti prisutan i u nekoj budućoj sličnoj situaciji? & 4,21 & 1,13 &,- 620 & 688 & 352 & ,843 \\
\hline 8.3. Je li taj uzrok nešto što utječe samo na ovu situaciju ili može utjecati i na druge situacije u Vašem životu? & 4,32 & 1,29 &,- 834 & ,416 & 462 &, 840 \\
\hline 8.4. Da Vam se dogodi ovakva situacija, koliko bi Vam bila važna? & 5,06 & 1,07 & $-1,282$ & 1,584 & ,471 & 841 \\
\hline
\end{tabular}




\begin{tabular}{|c|c|c|c|c|c|c|}
\hline & $M$ & $S D$ & 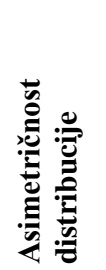 & 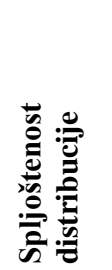 & 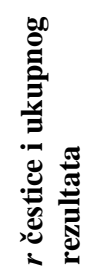 & 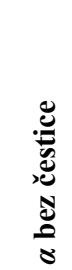 \\
\hline \multicolumn{7}{|l|}{ 9. VAŠ VAM JE PARTNER/ICA NAKLONJENIJI/A NEGO PRIJE. } \\
\hline 9.1. Ovisi li taj uzrok o Vama i Vašim karakteristikama ili o nekim drugim osobama i okolnostima? & 4,69 & ,99 &,- 626 & ,499 & ,067 & ,849 \\
\hline 9.2. Hoće li taj uzrok biti prisutan i u nekoj budućoj sličnoj situaciji? & 4,9 &, 87 &,- 404 &,- 199 & ,237 & ,845 \\
\hline 9.3. Je li taj uzrok nešto što utječe samo na ovu situaciju ili može utjecati i na druge situacije u Vašem životu? & 4,91 & 1,07 & $-1,039$ & 1,320 & ,305 & ,844 \\
\hline 9.4. Da Vam se dogodi ovakva situacija, koliko bi Vam bila važna? & 5,61 & ,76 & $-2,363$ & 6,949 & ,332 & ,844 \\
\hline \multicolumn{7}{|l|}{$\begin{array}{l}\text { 10. PRIJAVLJUJETE SE ZA MJESTO KOJE ZAISTA ŽELITE DOBITI (npr. važan posao, upis na } \\
\text { željeni fakultet) I DOBIVATE GA. }\end{array}$} \\
\hline 10.1. Ovisi li taj uzrok o Vama i Vašim karakteristikama ili o nekim drugim osobama i okolnostima? & 5,36 & ,90 & $-1,737$ & 4,158 & ,312 & ,844 \\
\hline 10.2. Hoće li taj uzrok biti prisutan i u nekoj budućoj sličnoj situaciji? & 5,30 &, 83 &,- 880 &,- 036 & ,307 &, 844 \\
\hline 10.3. Je li taj uzrok nešto što utječe samo na ovu situaciju ili može utjecati i na druge situacije u Vašem životu? & 5,39 & 1,03 & $-2,049$ & 4,467 &, 513 &, 840 \\
\hline 10.4. Da Vam se dogodi ovakva situacija, koliko bi Vam bila važna? & 5,84 & ,49 & $-3,329$ & 10,807 & ,342 & ,845 \\
\hline \multicolumn{7}{|l|}{ 11. ODLAZITE NA „SPOJ“ KOJI LOŠE PROTIČE. } \\
\hline 11.1. Ovisi li taj uzrok o Vama i Vašim karakteristikama ili o nekim drugim osobama i okolnostima? & 3,88 &, 82 & ,094 & 1,044 &, 215 &, 846 \\
\hline 11.2. Hoće li taj uzrok biti prisutan i u nekoj budućoj sličnoj situaciji? & 3,76 & 1,01 &,- 550 &, 544 & ,298 & ,844 \\
\hline 11.3. Je li taj uzrok nešto što utječe samo na ovu situaciju ili može utjecati i na druge situacije u Vašem životu? & 3,43 & 1,45 &,- 257 &,- 970 & ,292 & ,845 \\
\hline 11.4. Da Vam se dogodi ovakva situacija, koliko bi Vam bila važna? & 3,89 & 1,37 &,- 203 &,- 778 & 271 &, 845 \\
\hline \multicolumn{7}{|l|}{ 12. DOBIVATE POVIŠICU PLAĆE. } \\
\hline 12.1. Ovisi li taj uzrok o Vama i Vašim karakteristikama ili o nekim drugim osobama i okolnostima? & 5,14 & ,91 & $-1,100$ & 1,698 &, 276 & ,845 \\
\hline 2.2. Hoće li taj uzrok biti prisutan i u nekoj budućoj sličnoj situaciji? & 4,97 & ,88 &,- 455 &,- 262 & ,300 & ,844 \\
\hline 12.3. Je li taj uzrok nešto što utječe samo na ovu situaciju ili može utjecati i na druge situacije u Vašem životu? & 5,06 & 1,01 & $-1,213$ & 1,704 & ,380 & ,843 \\
\hline 12.4. Da Vam se dogodi ovakva situacija, koliko bi Vam bila važna? & 5,60 &, 72 & $-1,984$ & 4,000 & ,428 & ,843 \\
\hline
\end{tabular}


Prilog 9b. Formiranje paketića Upitnika atribucijskog stila

\begin{tabular}{lll}
\hline Konstrukt & Paketić & Čestice \\
\hline Stabilnost & ASQ_P_stabilnost_1 & ASQ_posao2 + ASQ_pomoc2+ASQ_mjesto2_rec \\
& ASQ_P_stabilnost_2 & ASQ_govor2 + ASQ_neprijat2+ASQ_projekt2_rec \\
& ASQ_P_stabilnost_3 & ASQ_okolina2 + ASQ_spoj2+ASQ_naklon2_rec \\
& ASQ_P_stabilnost_4 & ASQ_bogati2_rec + ASQ_prijatelj2_rec+ASQ_povisica2_rec \\
\hline Internalnost & ASQ_P_internalnost_1 & ASQ_posao1+ASQ_pomoc1+ASQ_mjesto1_rec \\
& ASQ_P_internalnost_2 & ASQ_govor1+ASQ_neprijat1+ASQ_projekt1_rec \\
& ASQ_P_internalnost_3 & ASQ_okolina1+ASQ_spoj1+ASQ_naklon1_rec \\
& ASQ_P_internalnost_4 & ASQ_bogati1_rec+ASQ_prijatelj1_rec+ASQ_povisica1_rec \\
\hline Globalnost & ASQ_P_globalnost_1 & ASQ_posao3+ASQ_pomoc3+ASQ_mjesto3_rec \\
& ASQ_P_globalnost_2 & ASQ_govor3+ASQ_neprijat3+ASQ_projekt3_rec \\
& ASQ_P_globalnost_3 & ASQ_okolina3+ASQ_spoj3+ASQ_naklon3_rec \\
& ASQ_P_globalnost_4 & ASQ_bogati3_rec+ASQ_prijatelj3_rec+ASQ_povisica3_rec \\
\hline
\end{tabular}




\begin{tabular}{|c|c|c|c|c|c|c|}
\hline & $M$ & $S D$ & 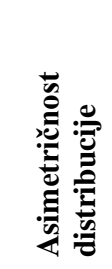 & 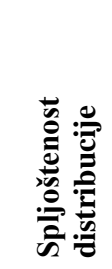 & 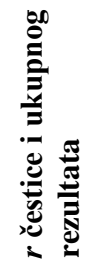 & 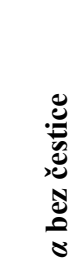 \\
\hline 1. Vjerujem da je druženje radi zabave s prijateljima jedno od važnih životnih zadovoljstava. & 4,29 & ,96 & $-1,362$ & 1,335 & ,080 & 818 \\
\hline 2. Poznati prizori, zvukovi i mirisi iz djetinjstva često mi donose bujicu predivnih uspomena. & 3,85 & 1,12 &,- 639 &,- 474 & ,368 & ,811 \\
\hline 3. Sudbina određuje velik dio mog života. & 2,38 & 1,19 & ,440 &,- 756 & ,337 & ,812 \\
\hline 4. Često razmišljam o tome što sam sve tijekom života trebala napraviti drugačije. & 3,02 & 1,18 &,- 057 &,- 810 & ,363 &, 811 \\
\hline 5. Donosim odluke uglavnom pod utjecajem osoba i stvari koje me okružuju. & 2,73 & ,97 &, 100 &,- 437 & ,258 & ,814 \\
\hline 6. Vjerujem da bi dan trebalo svakoga jutra unaprijed isplanirati. & 3,01 & 1,19 &,- 132 &,- 822 &,- 005 & ,821 \\
\hline 7. Ugodno mi je razmišljati o vlastitoj prošlosti. & 3,25 & 1,07 &,- 178 &,- 493 & 074 &, 818 \\
\hline 8. Ponašam se impulzivno. & 2,99 & 1,08 &, 025 &,- 524 & ,200 &, 815 \\
\hline 9. Ne brinem se ukoliko stvari nisu obavljene na vrijeme. & 2,53 & 1,22 & ,379 &,- 853 & ,037 &, 820 \\
\hline 10. Kada nešto želim postići, točno postavim ciljeve i razmotrim kako ih mogu ostvariti. & 3,74 & 1,06 &,- 590 &,- 308 &,- 050 & ,821 \\
\hline 11. Sve u svemu, u mojoj prošlosti ima puno više dobrih nego loših iskustava. & 4,03 & ,96 &,- 877 & ,263 &,- 008 & ,820 \\
\hline 12. Dok slušam svoju omiljenu glazbu, često mi se dogodi da u potpunosti izgubim pojam o vremenu. & 3,50 & 1,22 &,- 381 &,- 877 & ,449 & 808 \\
\hline 13. Poštivanje rokova i ispunjavanje obaveza dolazi prije zabave. & 3,63 & 1,06 &,- 449 &,- 494 &,- 067 &, 821 \\
\hline 14. Bit će što bude, bez obzira što ja radim. & 2,31 & 1,06 &, 528 &,- 369 & ,323 &, 812 \\
\hline 15. Uživam u pričama o tome kako je bilo u 'dobra stara vremena'. & 3,23 & 1,15 &,- 166 &,- 720 & ,358 &, 811 \\
\hline 16. Bolna iskustva iz prošlosti često se ponavljaju u mojim mislima. & 2,62 & 1,16 & ,292 &,- 798 & ,323 &, 812 \\
\hline 17. Nastojim živjeti što potpunije, dan za danom. & 3,74 & ,97 &,- 500 &,- 218 &, 249 &, 814 \\
\hline 18. Uzrujava me kada kasnim na sastanke i dogovore. & 3,81 & 1,05 &,- 790 & ,205 &, 135 &, 817 \\
\hline 19. Kad bih mogla, živjela bih svaki dan kao da mi je posljednji. & 3,62 & 1,26 &,- 576 &,- 707 & ,429 &, 809 \\
\hline 20. Sjećanja na dobra vremena lako mi padaju na pamet. & 3,60 & 1,04 &,- 431 &,- 338 & ,409 &, 810 \\
\hline 21. Svoje obaveze prema prijateljima i nadređenima ispunjavam na vrijeme. & 3,94 &, 86 &,- 616 & 085 & ,003 &, 819 \\
\hline 22. U prošlosti sam bila zlostavljana i odbacivana. & 1,88 & 1,16 & 1,129 &, 131 &, 118 &, 817 \\
\hline
\end{tabular}




\begin{tabular}{|c|c|c|c|c|c|c|}
\hline & $M$ & $S D$ & 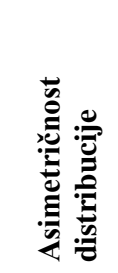 & 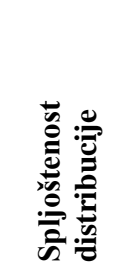 & 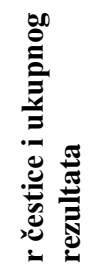 & 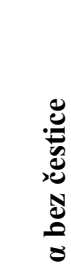 \\
\hline 23. Odluke donosim kako mi dođe u tom trenutku. & 2,74 & 1,06 & ,034 &,- 627 & 299 & 813 \\
\hline 24. Prihvaćam svaki dan takav kakav je, umjesto da ga pokušavam isplanirati. & 2,76 & 1,10 & ,328 &,- 512 & ,202 & ,815 \\
\hline 25. Ima previše neugodnih sjećanja iz prošlosti o kojima ne volim razmišljati. & 2,25 & 1,16 & 670 &,- 477 & ,200 & ,815 \\
\hline 26. Važno mi je unijeti uzbuđenje u svoj život. & 3,79 & ,92 &,- 583 &, 171 & ,322 & ,813 \\
\hline 27. U prošlosti sam činila greške koje bih željela poništiti. & 3,14 & 1,21 &,- 128 &,- 917 & ,265 & ,814 \\
\hline 28. Smatram da je važnije uživati u onome što radiš, nego to obaviti na vrijeme. & 3,37 & 1,02 &,- 065 &,- 550 & ,311 & ,813 \\
\hline 29. Hvata me nostalgija za mojim djetinjstvom. & 3,02 & 1,18 & ,021 &,- 811 & ,402 &, 810 \\
\hline 30. Prije donošenja odluke odvagnem dobre i loše strane te odluke. & 3,91 & ,95 &,- 894 & ,816 & 033 & ,819 \\
\hline 31. Riskiranje sprečava da mi život postane dosadan. & 2,93 & 1,05 &, 180 &,- 474 & ,413 & 810 \\
\hline 32. Za mene je važnije uživati u životnom putu nego se usmjeriti samo na cilj. & 3,44 & ,97 &,- 316 &,- 104 & ,340 & ,812 \\
\hline 33. Stvari rijetko ispadnu onako kako sam očekivala. & 2,86 & 1,05 & ,283 &,- 772 &, 424 &, 810 \\
\hline 34. Teško mi je zaboraviti neugodne prizore iz moje mladosti. & 2,30 & 1,12 & ,589 &,- 531 & ,220 & ,815 \\
\hline 35. Aktivnosti nisu toliko ugodne ako moram razmišljati o njihovim rezultatima. & 3,07 & 1,01 &,- 113 &,- 286 & ,320 & 812 \\
\hline 36. Čak i kad uživam u sadašnjosti, ne mogu izbjeći usporedbe sa sličnim iskustvima iz prošlosti. & 2,55 & 1,22 & ,407 &,- 777 & ,349 & ,811 \\
\hline 37. Nije moguće stvarno planirati budućnost jer se stvari previše mijenjaju. & 3,21 & 1,07 &,- 105 &,- 782 & ,393 &, 810 \\
\hline 38. Moj životni put kontroliraju sile na koje ne mogu utjecati. & 2,28 & 1,11 & ,468 &,- 760 & ,442 & ,809 \\
\hline 39. Nema smisla brinuti oko budućnosti kad ionako ni na što ne mogu utjecati. & 1,95 & 1,01 & ,906 &, 162 & ,247 &, 814 \\
\hline 40. Završavam zadatke na vrijeme zahvaljujući svom redovitom radu. & 3,44 & 1,10 &,- 356 &,- 450 &,- 070 & ,822 \\
\hline 41. Često se isključim dok članovi moje obitelji razgovaraju o tome kako je nekad bilo. & 2,48 & 1,08 & ,469 &,- 383 & ,086 &, 818 \\
\hline 42. Volim riskirati kako bih unijela uzbuđenje u svoj život. & 2,80 & 1,10 &, 126 &,- 632 & ,344 &, 812 \\
\hline 43. Obično radim popis stvari koje trebam obaviti. & 3,15 & 1,39 &,- 191 & $-1,211$ &, 122 & ,818 \\
\hline 44. Češće slijedim svoje srce nego glavu. & 3,23 & 1,07 &,- 198 &,- 584 & ,378 & 811 \\
\hline 45. Kada imam posla koji trebam obaviti sposobna sam odoljeti iskušenjima. & 3,38 & ,99 &,- 261 &,- 354 & ,060 & ,818 \\
\hline
\end{tabular}




\begin{tabular}{|c|c|c|c|c|c|c|}
\hline & $M$ & $S D$ & 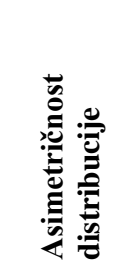 & 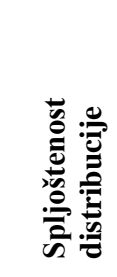 & 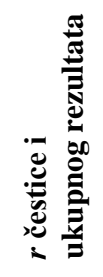 & 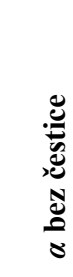 \\
\hline 46. Zna me ponijeti uzbuđenje trenutka. & 3,81 & ,98 &,- 865 & 5,588 & ,502 & ,808 \\
\hline 47. Današnji način života je prekompliciran, više bi mi odgovarao jednostavniji život, kakav je bio u prošlosti. & 2,95 & 1,26 & ,076 &,- 907 &, 315 & 812 \\
\hline 48. Više mi se sviđaju moji prijatelji koji su spontani nego oni predvidljivi. & 3,57 & 1,00 &,- 285 &,- 470 & ,402 & 811 \\
\hline 49. Volim obiteljske rituale i običaje koji se redovito ponavljaju. & 3,62 & 1,04 &,- 407 &,- 399 &, 274 & 813 \\
\hline 50. Razmišljam o lošim stvarima koje su mi se dogodile u prošlosti. & 2,48 & 1,14 & ,439 &,- 714 &, 311 & 812 \\
\hline 51. Ustrajem u teškim i dosadnim zadacima ukoliko mi to može pomoći u napredovanju. & 3,66 & 1,01 &,- 544 &,- 198 &, 063 &, 818 \\
\hline 52. Trošenje zarade na današnja zadovoljstva bolje je nego štednja za sigurnu budućnost. & 2,70 & ,94 &, 237 &, 154 & 212 & 815 \\
\hline 53. Sreća se često isplati više nego naporan rad. & 2,98 & 1,10 &, 053 &,- 672 & 239 & 814 \\
\hline 54. Razmišljam o dobrim stvarima koje sam propustila u svom životu. & 2,83 & 1,12 &, 062 &,- 787 &, 358 & 811 \\
\hline 55. Volim kada su moji odnosi s bliskim osobama strastveni. & 3,94 &, 86 &,- 564 & 156 & 267 & 814 \\
\hline 56. Uvijek će biti vremena da uhvatim korak s poslom. & 3,22 & ,96 &, 033 &,- 293 &, 320 & 812 \\
\hline
\end{tabular}


Prilog 10b. Formiranje paketića Zimbardovog inventara vremenskih perspektiva

\begin{tabular}{lll}
\hline Konstrukt & Paketić & Čestice \\
\hline Prošlost negativna & PN_P_1 & ZTPI_4 + ZTPI_22 + ZTPI_34 + ZTPI_54 \\
& PN_P_2 & ZTPI_5 + ZTPI_27 + ZTPI_36 \\
& PN_P_3 & ZTPI_16 + ZTPI_33 + ZTPI_50 \\
\hline Prošlost pozitivna & PP_P_1 & ZTPI_2 + ZTPI_15 + ZTPI_29 \\
& PP_P_2 & ZTPI_7 + ZTPI_20 + ZTPI_41_rec \\
& PP_P_3 & ZTPI_11 + ZTPI_25_rec + ZTPI_49 \\
\hline Sadašnjost hedonistička & SH_P_1 & ZTPI_1+ZTPI_23+ZTPI_42 \\
& SH_P_2 & ZTPI_8+ZTPI_26+ZTPI_44 \\
& SH_P_3 & ZTPI_12+ZTPI_28+ZTPI_46 \\
& SH_P_4 & ZTPI_17+ZTPI_31+ZTPI_48 \\
& SH_P_5 & ZTPI_19+ZTPI_32+ZTPI_55 \\
\hline Sadašnjost fatalistička & SF_P_1 & ZTPI_3 + ZTPI_35+ ZTPI_37 \\
& SF_P_2 & ZTPI_14 + ZTPI_38+ ZTPI_39 \\
& SF_P_3 & ZTPI_47 + ZTPI_53+ ZTPI_52 \\
\hline B_P_1 & ZTPI_6 + ZTPI_13 + ZTPI_24_rec + ZTPI_43 \\
\hline Budućnost & B_P_2 & ZTPI_9_rec + ZTPI_18 + ZTPI_30 \\
& B_P_3 & ZTPI_10 + ZTPI_45 + ZTPI_21 \\
& B_P_4 & ZTPI_40 + ZTPI_51 + ZTPI_56_rec \\
\hline
\end{tabular}


Prilog 11. Popis tvrdnji i prikaz osnovnih deskriptivnih pokazatelja na razini pojedine tvrdnje subskale Konstruktivne komunikacije Upitnika komunikacijskih obrazaca prilikom sukoba $(N=236)$.

\begin{tabular}{|c|c|c|c|c|c|c|c|}
\hline & & $M$ & $S D$ & 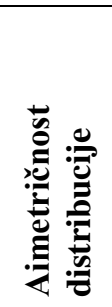 & 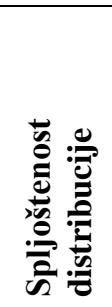 & 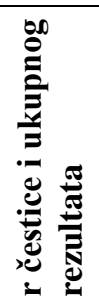 & 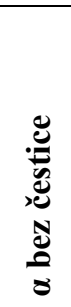 \\
\hline & $\begin{array}{l}\text { Oba partnera pokušavaju raspravljati o } \\
\text { problemu. }\end{array}$ & 7.16 & 1.77 & -.953 & .676 & .432 & .695 \\
\hline 2. & $\begin{array}{l}\text { Oba partnera okrivljuju, optužuju i kritiziraju } \\
\text { jedno drugo.* }\end{array}$ & 7.00 & 2.14 & -.877 & .615 & .465 & .686 \\
\hline 3. & $\begin{array}{l}\text { Oba partnera izražavaju svoje osjećaje jedno } \\
\text { drugome. }\end{array}$ & 6.93 & 1.78 & -.905 & .570 & .651 & .636 \\
\hline & $\begin{array}{l}\text { Oba partnera prijete jedno drugome } \\
\text { negativnim posljedicama.* }\end{array}$ & 6.39 & 1.75 & -.592 & -.347 & .372 & .718 \\
\hline 5. & $\begin{array}{l}\text { Oba partnera predlažu moguća rješenja i } \\
\text { kompromise. }\end{array}$ & 7.83 & 1.80 & -1.944 & 3.812 & .385 & .706 \\
\hline 6. & $\begin{array}{l}\text { Muškarac naziva ženu ružnim imenima, psuje } \\
\text { ili napada njenu osobnost.* }\end{array}$ & 8.51 & 1.28 & -2.777 & 7.325 & .423 & .702 \\
\hline 7. & $\begin{array}{l}\text { Žena naziva muškarca ružnim imenima, psuje } \\
\text { ili napada njegovu osobnost.* }\end{array}$ & 8.35 & 1.43 & -3.169 & 11.199 & .390 & .704 \\
\hline
\end{tabular}


Prilog 12. Scree plot prikazi latentne strukture instrumenata korištenih u glavnom istraživanju ( $N$ $=236$ ).

a) Modificirani Indeks kvalitete braka

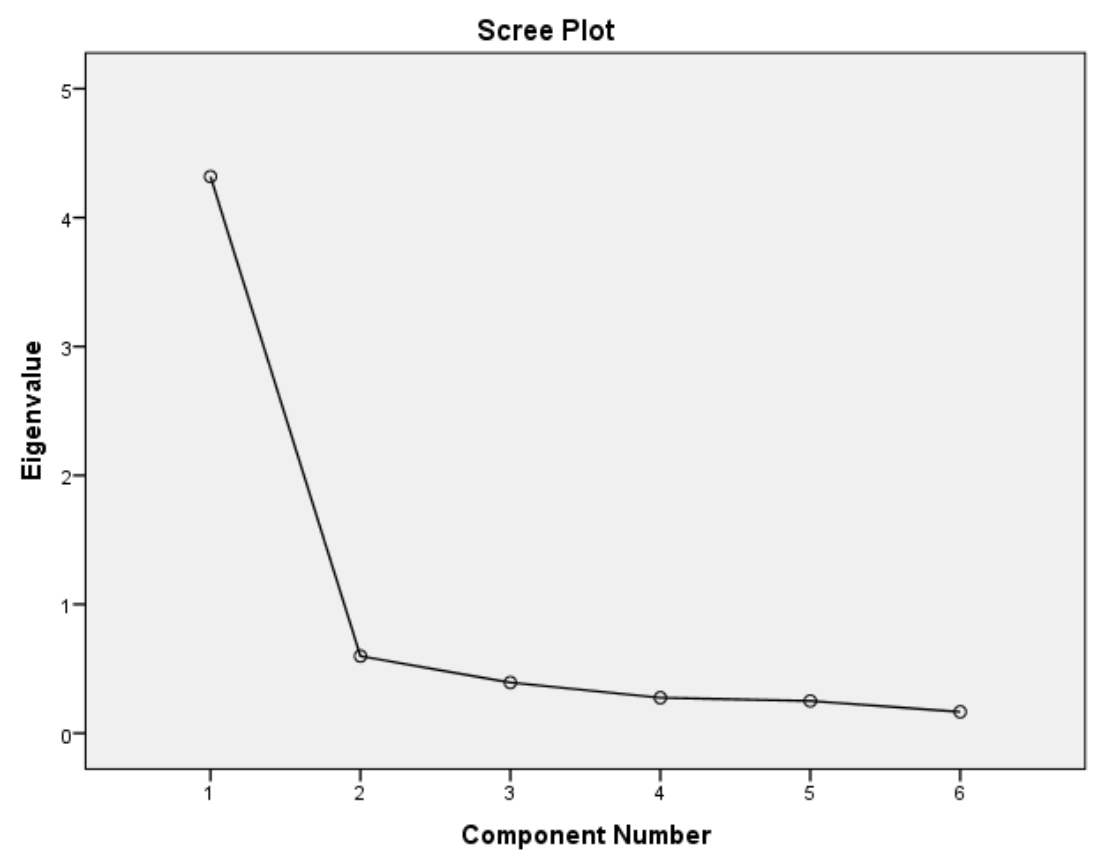

b) Mjera namjere konstruktivne komunikacije prilikom sukoba

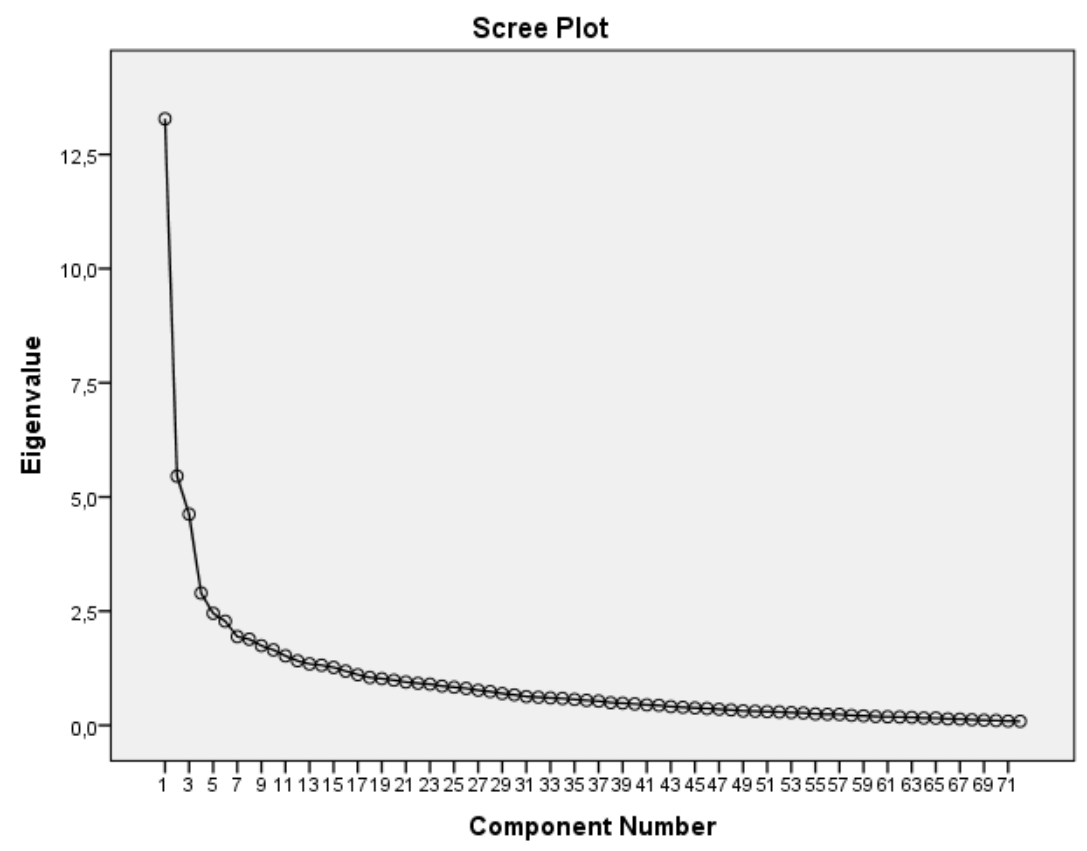


c) Mjera atribucija u vezi

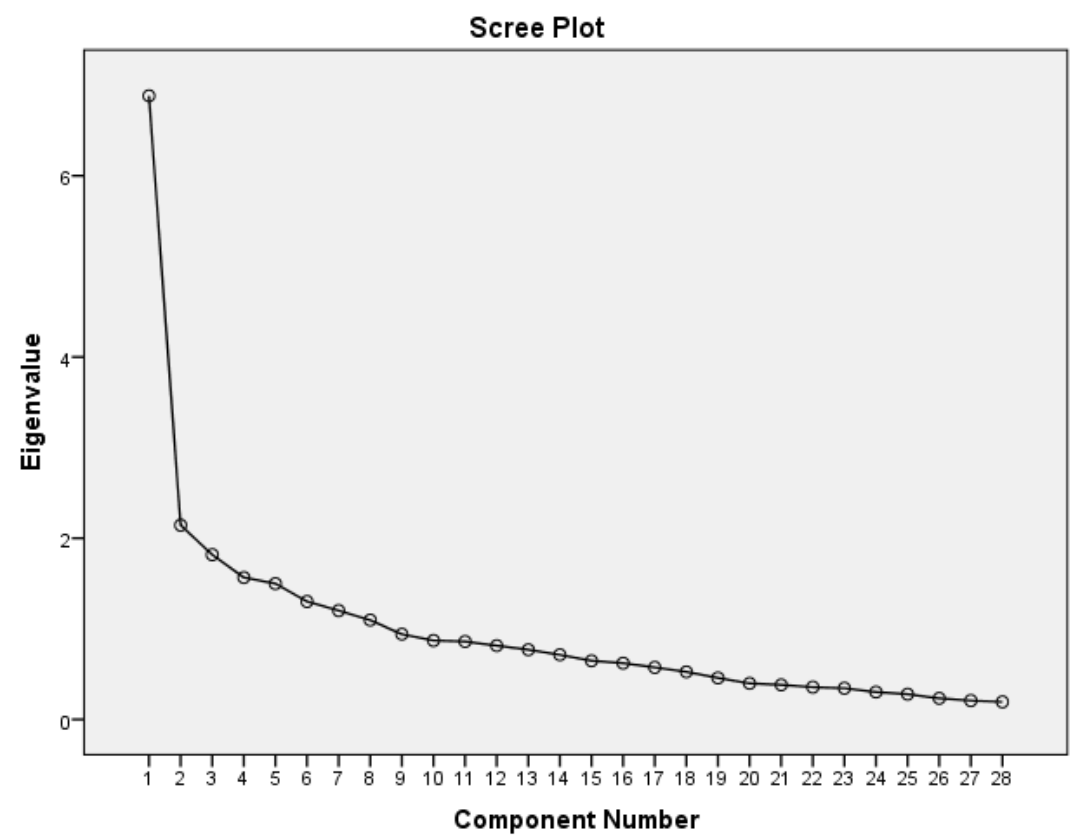

d) Upitnik atribucijskog stila

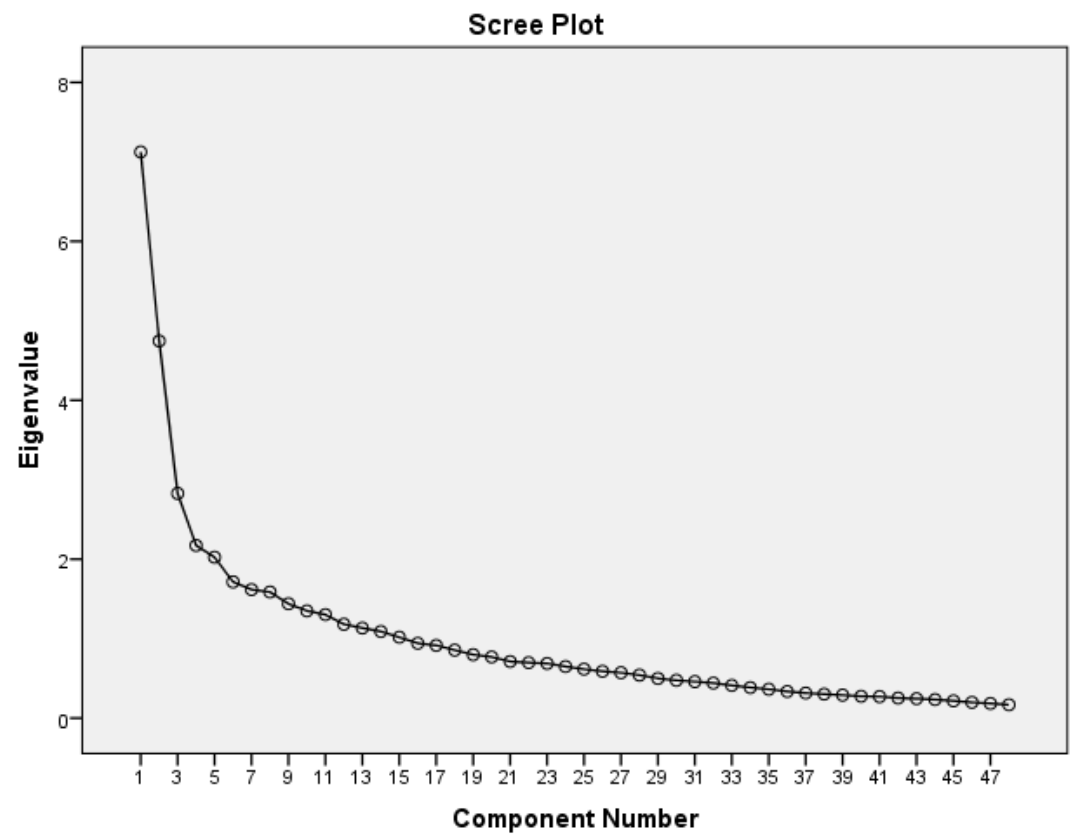


d) Zimbardov inventor vremenskih perspektiva

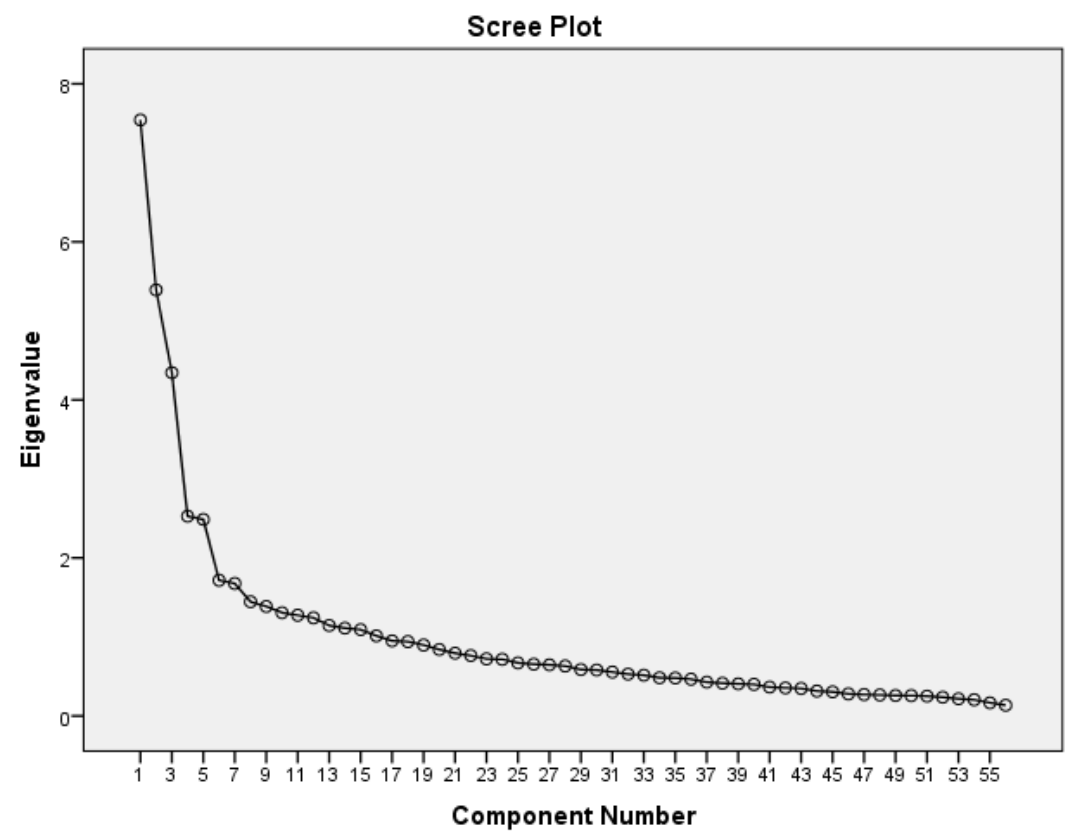

e) Skala konstruktivne komunikacije iz Upitnika komunikacijskih obrazaca prilikom sukoba

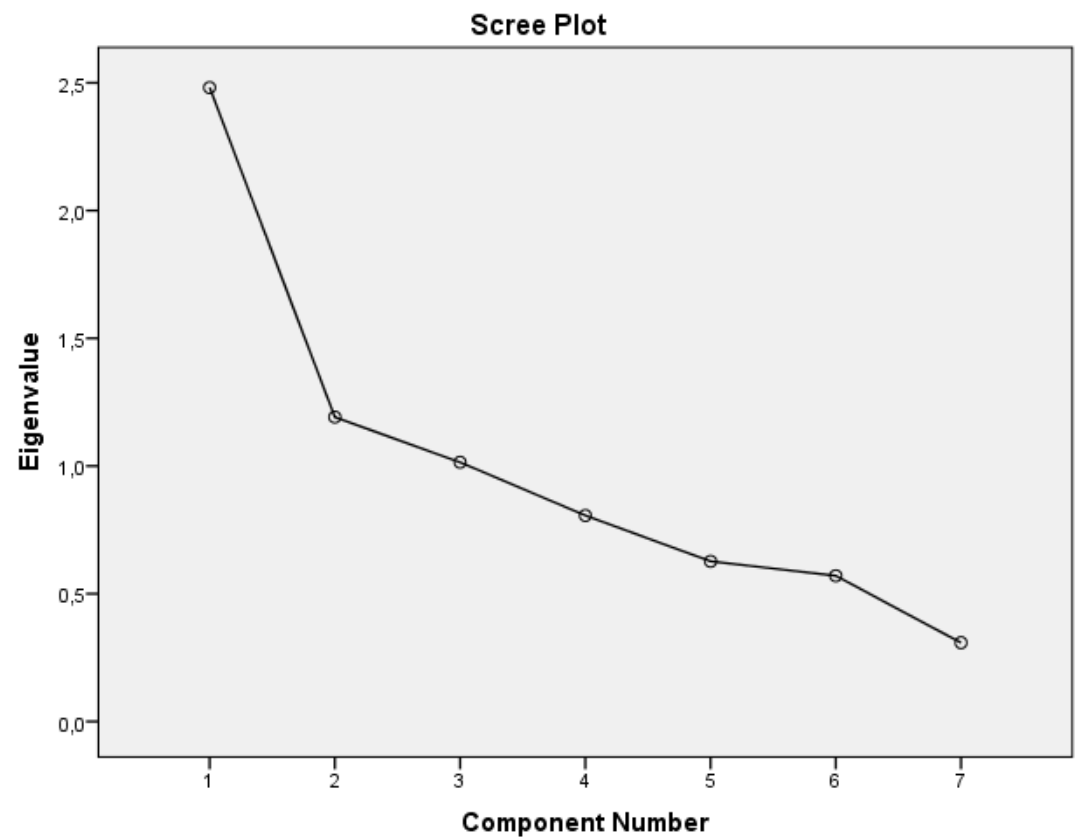


Prilog 13. Konačna verzija upitnika korištenog u istraživanju u prvoj točki mjerenja, primijenjena putem sustava SurveyMonkey. 


\section{()}

\section{Sukobi u vezama_1}

Sudjelovanje u istraživanju o bliskim odnosima

Istraživačica: Tina Krznarić, tkrznari@ffzg.hr

\section{Poštovani/Poštovana,}

pred Vama se nalazi upitnik o Vašim stavovima i mišljenjima o Vašoj trenutnoj romantičnoj vezi. Upitnik se sastoji od nekoliko dijelova i sastavljen je za potrebe istraživanja koje provodi psihologinja Tina Krznarić u okviru svoje doktorske disertacije na poslijediplomskom doktorskom studiju psihologije na Filozofskom fakultetu u Zagrebu, pod mentorstvom prof. dr. sc. Željke Kamenov. Istraživanje se provodi u sklopu projekta «Razvoj novog modela komunikacije prilikom sukoba u bliskim vezama», sufinanciranog putem Europskog socijalnog fonda. Tema istraživanja su bliski odnosi kod mladih odraslih osoba.

Vaše sudjelovanje u ovom istraživanju je potpuno dobrovoljno. Ukoliko odlučite sudjelovati, molim Vas da na pitanja odgovarate što spontanije i što iskrenije možete, te da ne izostavite niti jedno pitanje. Detaljne upute i način odgovaranja nalaze se u upitniku.

Ovo istraživanje provest će se u dvije vremenske točke. Otprilike mjesec dana nakon što ispunite ovaj upitnik, student/ica psihologije koji Vas je kontaktirao na e-mail će Vam poslati link za kraći upitnik. Molim Vas da tada ispunite i taj upitnik. Vaš identitet (odnosno ime i prezime) zna samo student/ica koji Vas je kontaktirao, no ta osoba neće imati pristup rezultatima. Nigdje u upitniku ne trebate navoditi svoje ime i prezime ili druge osobne podatke pomoću kojih bi Vas bilo moguće identificirati te će Vaši odgovori biti spremljeni isključivo pod šifrom, a rezultati istraživanja bit će prikazivani isključivo na grupnoj razini i korišteni samo u znanstvene svrhe. Stoga ne postoji način da se Vaši odgovori povežu s Vama osobno, čime je zajamčena potpuna anonimnost. Kako bismo mogli upariti Vaše odgovore u ovom upitniku s onima koje ćete dati za mjesec dana, molimo Vas da na prvoj stranici upitnika upišete svoju šifru, koju ste dobili od studenta koji Vas je kontaktirao. Istu ćete šifru navesti kada Vas idući put kontaktiramo, kako bi se izbjegla potreba za korištenjem Vašeg imena i prezimena i sačuvala Vaša anonimnost.

Molim Vas da upitnik ispunjavate u miru, bez prekidanja i neovisno o svom partneru, te da međusobno ne gledate odgovore! To nam je iznimno važno zbog valjanosti prikupljenih podataka. Ispunjavanje upitnika traje oko 45 minuta.

Provedbu istraživanja odobrilo je Etičko povjerenstvo Odsjeka za psihologiju Filozofskog fakulteta 
u Zagrebu.

Nadam se da ćete pristati sudjelovati u ovom istraživanju jer su nam potrebni odgovori što većeg broja ljudi kako bismo dobili bolji uvid u bliske odnose mladih odraslih osoba. Ukoliko imate bilo kakvih pitanja, slobodno se javite na gore navedenu e-mail adresu. Ako imate neke pritužbe na provedeni postupak ili ste zabrinuti zbog nečega što ste tijekom istraživačkog postupka doživjeli, molimo Vas da se obratite na etikapsi@ffzg.hr.

Zahvaljujemo Vam unaprijed na Vašem sudjelovanju, te Vas srdačno i s poštovanjem pozdravljamo! 


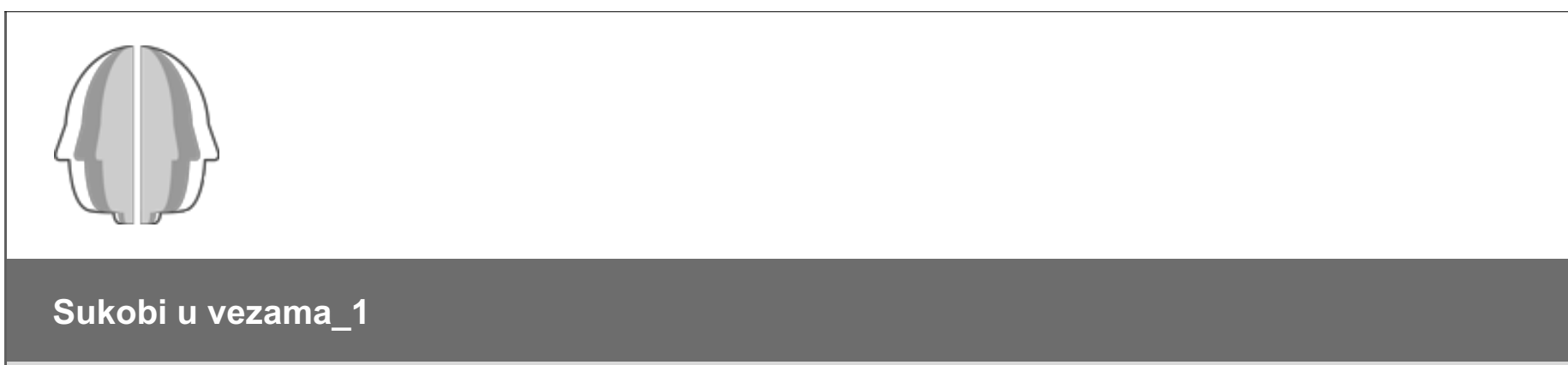

* 1. Molimo Vas da upišete šifru ispitanika koju ste dobili putem e-maila, a kojom se jamči Vaša anonimnost. 


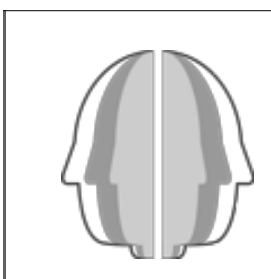

\section{Sukobi u vezama_1}

* 2. Spol

Muško

Žensko

3. Dob

\section{Mjesto stalnog boravka}

selo ili manje mjesto (do 10000 stanovnika)

manji grad (do 100000 stanovnika)

$\operatorname{grad}($ do 500000 stanovnika)

veliki grad (više od 500000 stanovnika)

5. Veličina mjesta u kojem ste proveli najveći dio svog života do punoljetnosti

selo ili manje mjesto (do 10000 stanovnika)

manji grad (do 100000 stanovnika)

grad (do 500000 stanovnika)

veliki grad (više od 500000 stanovnika)

6. Jesu li Vaša oba roditelja živa?

DA

NE 
7. Jesu li Vaši roditelji rastavljeni/razvedeni?

DA

NE 


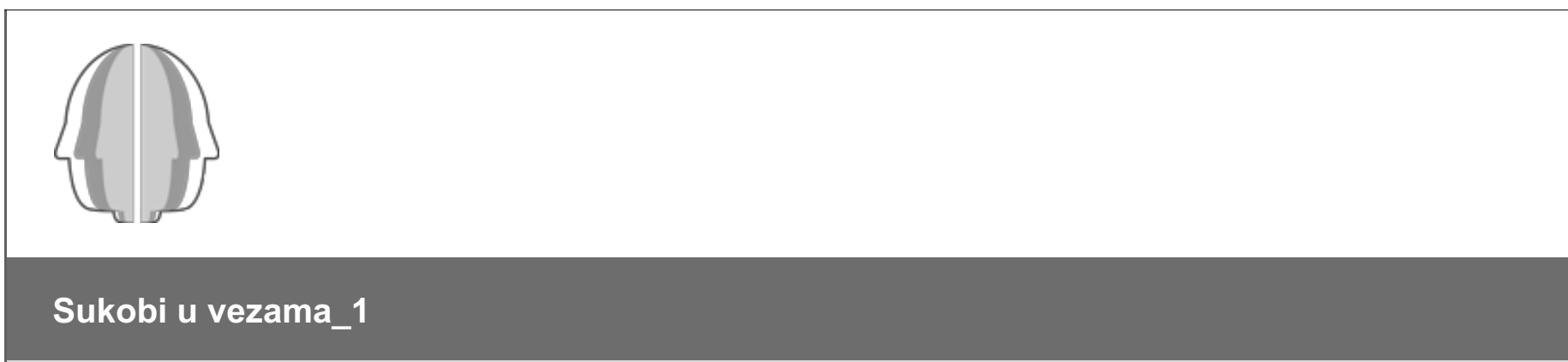

8. Ako da, koliko ste godina imali kad su prestali živjeti zajedno? 


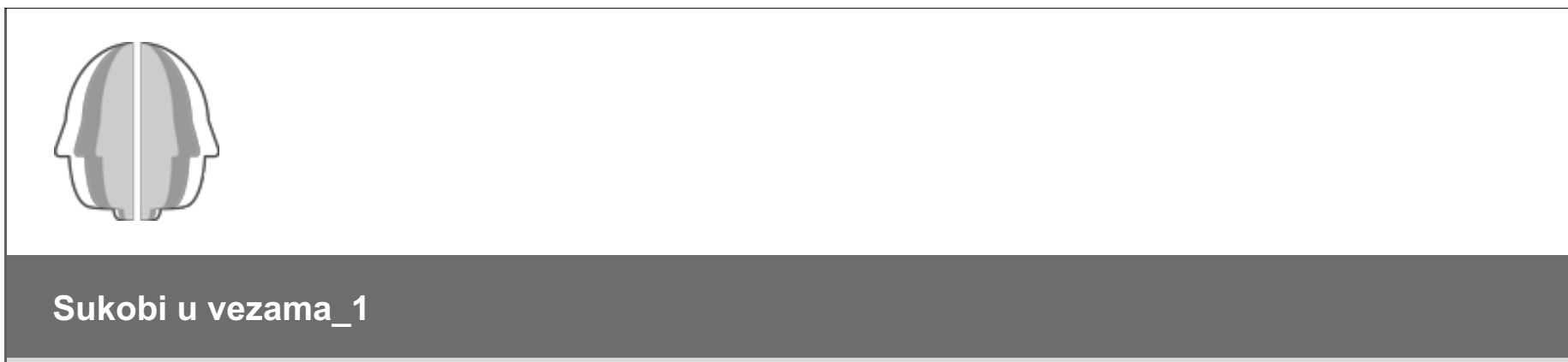

9. Jeste li trenutno u ljubavnoj vezi?

DA

NE

10. Koliko dugo ste Vi i Vaš/a partner/ica u vezi (upišite broj mjeseci)

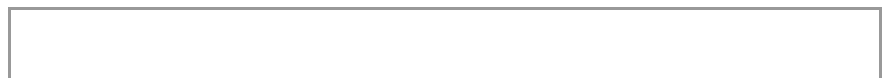

11. Živite li s partnerom/icom?

DA

NE 


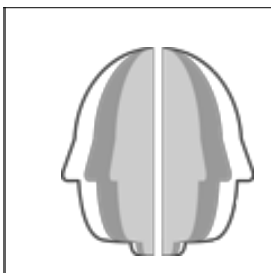

\section{Sukobi u vezama_1}

Imajući na umu Vašu sadašnju vezu, procijenite u kojoj se mjeri slažete s navedenim tvrdnjama, te odaberite odgovarajući kružić. Pritom 1 znači „uopće se ne slažem“, a 7 „u potpunosti se slažem“.

12. Imajući na umu Vašu sadašnju vezu, procijenite u kojoj se mjeri slažete s navedenim tvrdnjama, te odaberite odgovarajući kružić. Pritom 1 znači „uopće se ne slažem“, a 7 „u potpunosti se slažem“.

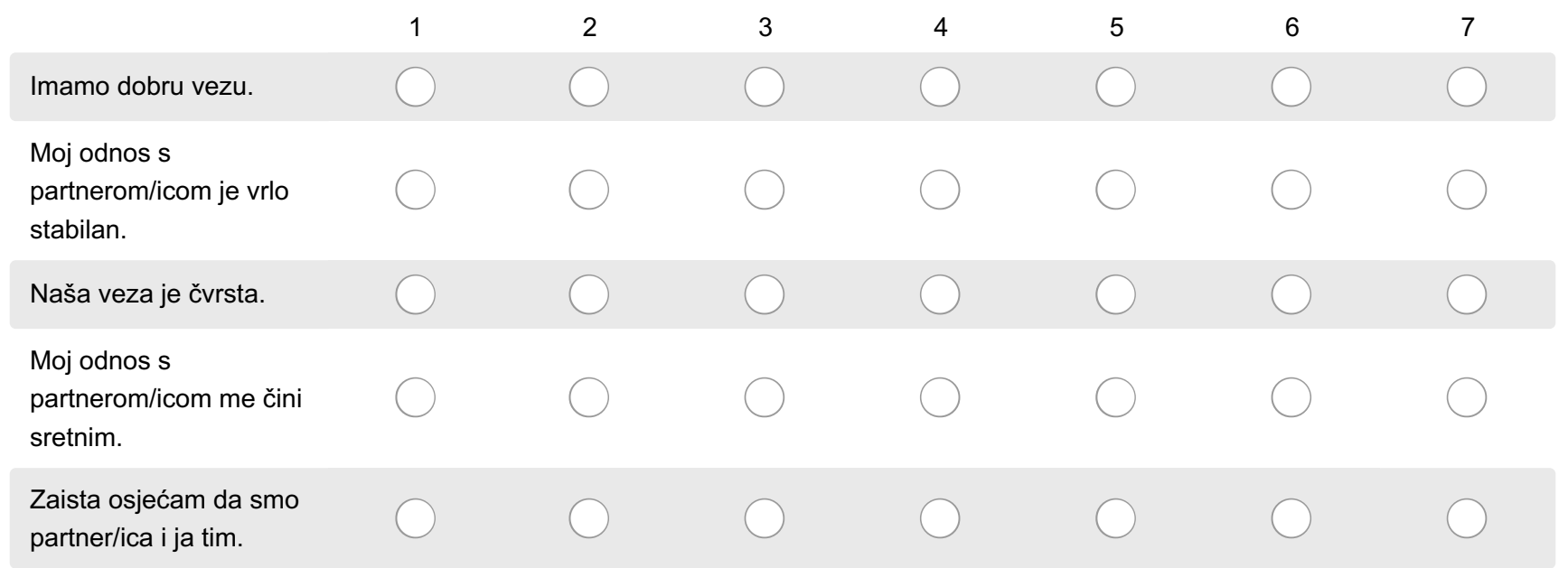

13. Uzevši sve u obzir, koliko ste sretni u vezi s Vašim/om partnerom/icom?

$$
\text { Jako }
$$

nesretan

Jako sretan

1 


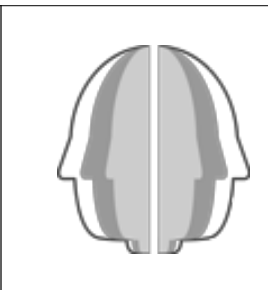

\section{Sukobi u vezama_1}

Ovaj upitnik ispituje neke Vaše stavove prema konstruktivnom rješavanju sukoba u vezi. Molimo Vas da pročitate definiciju ponašanja, te izrazite stupanj slaganja s pojedinom tvrdnjom odabirom kružića ispod pojedinih brojeva.

Definicija ponašanja: Konstruktivno rješavanje sukoba je ponašanje koje uključuje otvorenu raspravu o konfliktnim temama, slobodno i pozitivno izražavanje emocija te zajednički trud oko postizanja rješenja u sukobu.

Sukob se zbiva kad pojedinci ili grupe doživljavaju razlike neuskladivim ili vide jedni druge kao prijetnju svojim potrebama, vrijednostima ili sredstvima. Pretpostavlja niz ponašanja u međuljudskim odnosima koja se kreću u rasponu od napetosti i neslaganja do svađe, pa do različitih oblika nasilja.

\section{Konstruktivno rješavanje sukoba u vezi za mene je}

Iznimno loše

$\begin{array}{lllllll}1 & 3 & 4 & 5 & 6 & 7 \\ 0 & 0 & 0 & 0\end{array}$

15. Konstruktivno rješavanje sukoba u vezi za mene je

Sasvim bezvrijedno

10304

16. Za mene je konstruktivno rješavanje sukoba u vezi

Vrlo neugodno

$\bigcirc \quad 3$

4

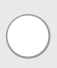

Iznimno vrijedno

7

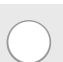

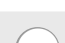

17. Konstruktivno rješavanje sukoba u vezi za mene je

Dosadno
4

5

6

Vrlo ugodno

$\bigcirc$

7

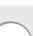


18. Konstruktivno rješavanje sukoba omogućit će mi da bolje razumijem svojeg/u partnera/icu.

Uopće nije

vjerojatno

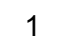

(
2

O

3

$\bigcirc$

4

O

6

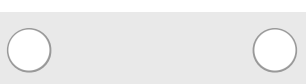

Vrlo vjerojatno

7

Iznimno dobro

7

$0^{6} \bigcirc^{7}$

20. Konstruktivno rješavanje sukoba omogućit će da partner/ica i ja imamo kvalitetniju vezu.

\section{Uopće nije}

vjerojatno

1

0
2

3

3

2

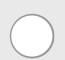

4

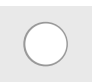

5

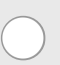

Vrlo vjerojatno

6

Iznimno dobro

6

7

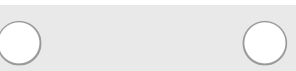

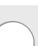

22. Konstruktivno rješavanje sukoba omogućit će mi da se osjećam dobro u vezi sebe.

Uopće nije

vjerojatno

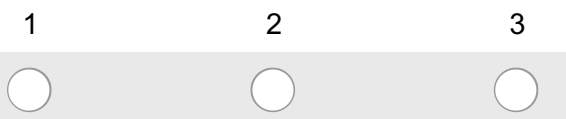

4

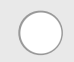

Vrlo vjerojatno

6

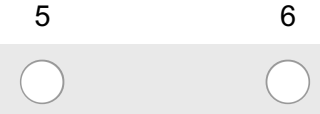

7

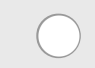

23. Osjećati se dobro u vezi sebe za mene bi bilo

Iznimno loše

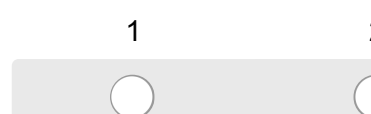

2

$\bigcirc$

3

$\bigcirc$

4

$\bigcirc$

5

0

Iznimno dobro

6

7

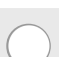

24. Konstruktivno rješavanje sukoba unaprijedit će našu vezu.

\begin{abstract}
Uopće nije
\end{abstract}
vjerojatno

1

2

3

4

5

6

Vrlo vjerojatno

0


25. Unaprijediti našu vezu za mene bi bilo

Iznimno loše

$\begin{array}{lllllll}1 & 2 & 3 & 4 & 5 & 6 & 7 \\ 0 & 0 & 0 & 0\end{array}$

26. Konstruktivno rješavanje sukoba omogućit će da identificiramo uzrok problema u našoj vezi.

Uopće nije

vjerojatno

1

2

3

4

5

6

Vrlo vjerojatno
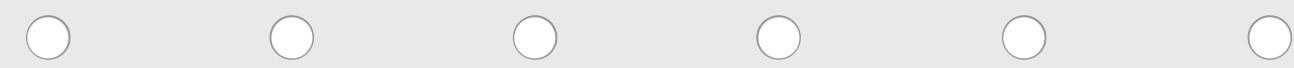

27. Identificirati uzrok problema u našoj vezi za mene bi bilo Iznimno loše

$\begin{array}{ccccccc}\text { Iznimno loše } & & & 6 & 6 \\ 1 & 2 & 3 & 4 & 5 & 7\end{array}$

28. Konstruktivno rješavanje sukoba omogućit će da pronađemo rješenje problema u vezi.

Uopće nije

vjerojatno

1

2

3

4

5
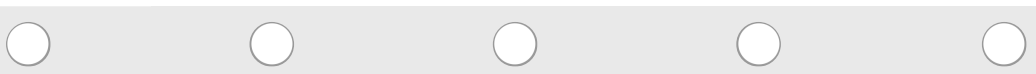

6

Vrlo vjerojatno

7

29. Pronaći rješenje problema u vezi za mene bi bilo

Iznimno loše

$\begin{array}{lllllll}1 & 3 & 4 & 5 & 6 & 7 \\ 0 & 0 & 0 & 0\end{array}$

30. Konstruktivno rješavanje sukoba skraćuje trajanje sukoba.

Uopće nije
vjerojatno

1

0
2

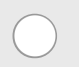

3

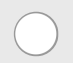

4

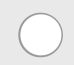

5

0

6

Vrlo vjerojatno

7

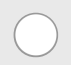

31. Skratiti trajanje sukoba za mene bi bilo Iznimno loše

$\begin{array}{lllllll}1 & 2 & 3 & 4 & 5 & 6 & 7 \\ 0\end{array}$


32. Ukoliko bih konstruktivno rješavao/la sukob, bojao/la bih se da ću biti povrijeđen/a.

Uopće nije

vjerojatno
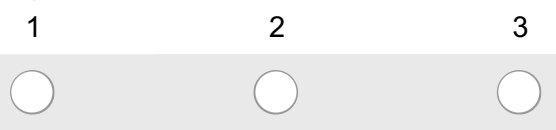

4

5

6

Vrlo vjerojatno
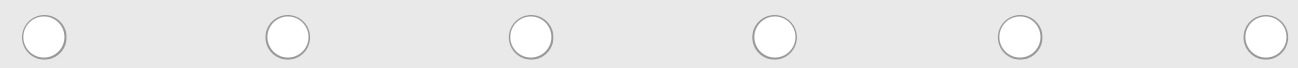

7

33. Biti povrijeđen/a za mene bi bilo

Iznimno loše

$\begin{array}{lllllll}1 & 2 & 3 & 4 & 5 & 7 & 6 \\ 7\end{array}$

34. Konstruktivnim rješavanjem sukoba došlo bi do zaoštravanja odnosa s partnerom/icom.

Uopće nije

vjerojatno

1

2

3

5

6

Vrlo vjerojatno
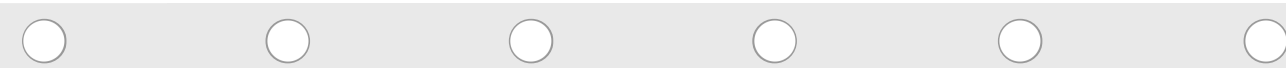

35. Zaoštravanje odnosa s partnerom/icom za mene bi bilo

Iznimno loše

$\begin{array}{lllllll}1 & 3 & 4 & 5 & 6 & 7 \\ 0 & 0 & 0 & 0\end{array}$

36. Konstruktivnim rješavanjem sukoba bih povrijedio/la partnera/icu.

Uopće nije

vjerojatno

$\begin{array}{lllllll}2 & 3 & 4 & 5 & 6 & 7 \\ 0 & 0 & 0 & 0\end{array}$

37. Povrijediti partnera/icu za mene bi bilo

Iznimno loše

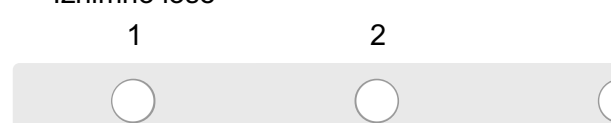

3

0

4

0

5

0

Iznimno dobro

6

7

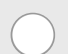

38. Konstruktivno rješavanje sukoba može dovesti do prekida veze.

Uopće nije

vjerojatno

1

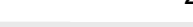

2

3

0

4

0

Vrlo vjerojatno

6

7 
39. Prekid veze za mene bi bio

Iznimno loš

$\begin{array}{lllllll}1 & 3 & 4 & 5 & 6 & 7 \\ 0 & 0 & 0 & 0\end{array}$

40. Većina ljudi koji su mi važni smatra da konstruktivno rješavati sukobe u vezi. Ne trebam

$\begin{array}{lllllll}1 & 2 & 3 & 4 & 5 & 0^{7} & \\ 0 & 0 & 0 & 0\end{array}$

41. Većina mojih prijatelja konstruktivno rješava sukobe u vezi.
U potpunosti
netočno
1
2
3
4
5
U potpunosti

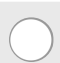

0
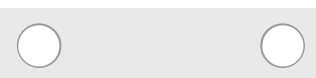
6
točno
7

42. Od mene se očekuje da konstruktivno rješavam sukobe u vezi.

U potpunosti netočno

1

$\bigcirc$
2

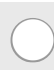

3

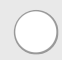

4

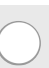

U potpunosti točno

6

7

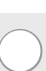

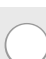

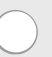

43. Većina ljudi čije mišljenje cijenim bi odobravala da konstruktivno rješavam sukobe u vezi.

U potpunosti se ne slažem

12

3

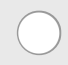

4

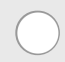

5

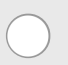

U potpunosti se slažem

7

\section{6}

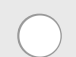

44. MOJ/A PARTNER/ICA smatra da trebam konstruktivno rješavati sukobe u vezi.

Uopće nije

vjerojatno

1

$\bigcirc$
2

$\bigcirc$

3

$\bigcirc$

4

$\bigcirc$

5

$\bigcirc$

Vrlo vjerojatno

7

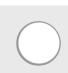

45. Moji MUŠKI PRIJATELJI smatraju da trebam konstruktivno rješavati sukobe u vezi.

\begin{abstract}
Uopće nije
vjerojatno
\end{abstract}

1

2

3

4

5

6

Vrlo vjerojatno

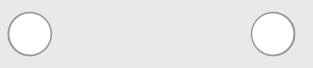

0


46. Moje ŽENSKE PRIJATELJICE smatraju da trebam konstruktivno rješavati sukobe u vezi. Uopće nije vjerojatno

1

(

2

3

4

5

6

Vrlo vjerojatno

$\bigcirc$

0

0

0

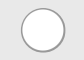

0

7

47. Moji RODITELJI smatraju da trebam konstruktivno rješavati sukobe u vezi.

Uopće nije

vjerojatno

1

2

3

4

5

Vrlo vjerojatno

0

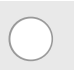

0
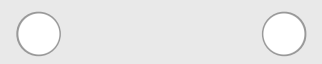

6

7

48. Moji KOLEGE smatraju da trebam konstruktivno rješavati sukobe u vezi.

Uopće nije

vjerojatno

1

O
2

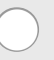

3

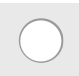

4

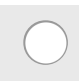

5

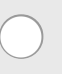

Vrlo vjerojatno

6

7

49. Općenito govoreći, koliko Vam je stalo do toga što Vaši MUŠKI PRIJATELJI misle da biste trebali činiti? Niti malo

12

3

4

5

6

Jako puno
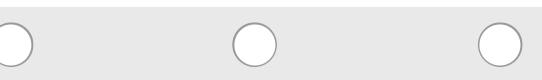

7

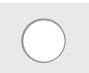

50. Općenito govoreći, koliko Vam je stalo do toga što Vaše ŽENSKE PRIJATELJICE misle da biste trebali učiniti?

Niti malo

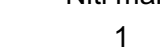

0
2

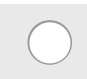

3

0

4

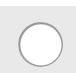

5

0

Jako puno

6

7

0

51. Općenito govoreći, koliko Vam je stalo do toga što Vaši RODITELJI misle da biste trebali činiti? Niti malo

1

1

2

2

3

4
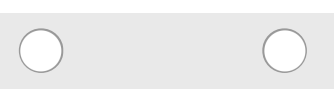

5

5

6

Jako puno

52. Općenito govoreći, koliko Vam je stalo do toga što VAŠ/A PARTNER/ICA misli da biste trebali činiti? Niti malo

1

2

3
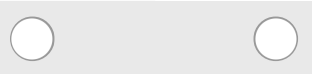

0

5

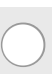

Jako puno

6

7 
53. Općenito govoreći, koliko Vam je stalo do toga što Vaši KOLEGE misle da biste trebali činiti? Niti malo

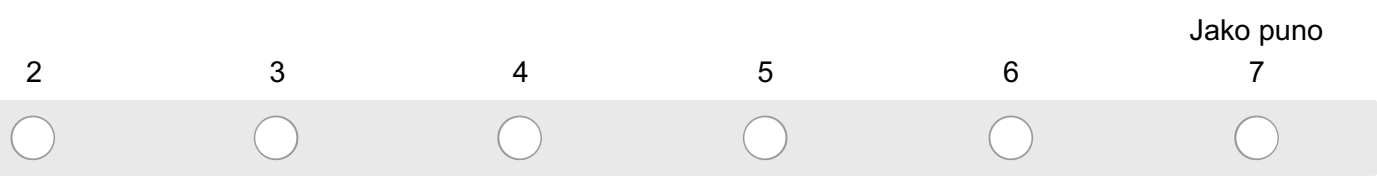

54. Konstruktivno rješavanje sukoba u vezi za mene je Iznimno teško

$\begin{array}{ccccccc}1 & 2 & 3 & 4 & 5 & 6 & 7 \\ 0 & 0 & 0 & 0 & 0 & 0 & 0\end{array}$

55. Hoću li ili neću konstruktivno rješavati sukobe u vezi ovisi isključivo o meni.

$\begin{array}{ccccccc}\begin{array}{c}\text { U potpunosti se } \\ \text { ne slažem } \\ 1\end{array} & 2 & 3 & 4 & 5 & 6 & \begin{array}{c}\text { U potopunosti se } \\ \text { slažem }\end{array} \\ 0 & 0 & 0 & 0 & 0 & 7\end{array}$

56. Uvjeren sam da bih mogao konstruktivno rješavati sukobe u vezi, kada bih to htio.

U potpunosti netočno

1

$\bigcirc$
2

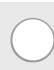

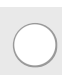

4

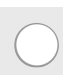

5

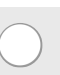

U potpunosti točno

6

7

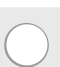

57. Konstruktivno rješavanje sukoba u vezi za mene je

Nemoguće

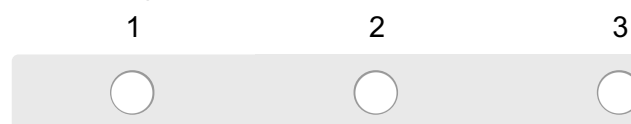

3

O

4

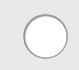

5

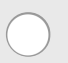

Moguće

7

58. Konstruktivno rješavanje sukoba u vezi u situaciji kada se razgovor odvija u prisutnosti drugih ljudi za mene bi bilo

Iznimno teško

1

2

0

3

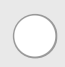

4

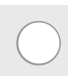

5

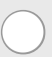

Iznimno lako

6

7

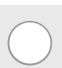

59. Namjeravam redovito konstruktivno rješavati sukobe u vezi.

Uopće nije

vjerojatno

1

0
2

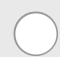

3

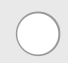

4

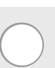

Vrlo vjerojatno

6

7 
60. Siguran/a sam da ću prilikom sljedećeg sukoba u vezi sukob rješavati konstruktivno.

U potpunosti se ne slažem

\begin{tabular}{|c|c|c|c|c|c|}
\hline & & & & & $\begin{array}{c}\text { U potpunosti se } \\
\text { slažem }\end{array}$ \\
\hline 2 & 3 & 4 & 5 & 6 & 7 \\
\hline
\end{tabular}

61. Potrudit ću se prilikom sukoba u vezi komunicirati konstruktivno.

\begin{tabular}{cccccc}
$\begin{array}{c}\text { U potpunosti se } \\
\text { ne slažem } \\
1\end{array}$ & 2 & 3 & 4 & 5 & \multicolumn{2}{c}{$\begin{array}{c}\text { U potpunosti se } \\
\text { slažem }\end{array}$} \\
& 0 & 0 & 0 & 0
\end{tabular}

62. Kada ne bih imao/la dovoljno vremena da se nađem sa svojim/om partner/icom, to bi mi otežalo konstruktivno komuniciranje prilikom sukoba.

\begin{tabular}{|c|c|c|c|c|c|c|}
\hline $\begin{array}{l}\text { U potpunosti se } \\
\text { ne slažem }\end{array}$ & & & & & & $\begin{array}{l}\text { U potpunosti se } \\
\text { slažem }\end{array}$ \\
\hline 1 & 2 & 3 & 4 & 5 & 6 & 7 \\
\hline
\end{tabular}

63. Koliko često Vas manjak vremena sprječava da se nađete sa svojim/om partner/icom? Jako rijetko

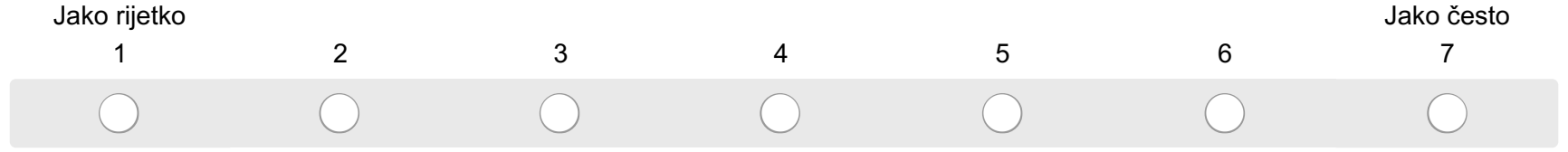

64. Kada bi me moje emocije potpuno obuzele, to bi mi otežalo konstruktivno komuniciranje prilikom sukoba.

\begin{tabular}{ccccccc}
$\begin{array}{c}\text { U potpunosti se } \\
\text { ne slažem } \\
1\end{array}$ & 2 & 3 & 4 & 5 & \multicolumn{2}{c}{$\begin{array}{c}\text { U potpunosti se } \\
\text { slažem }\end{array}$} \\
& & 0 & & & &
\end{tabular}

65. Koliko često Vas Vaše emocije potpuno obuzmu? Jako rijetko

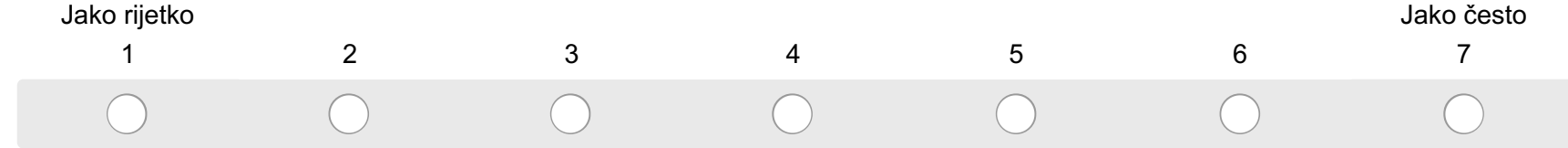


66. Kada moj/a partner/ica ne bi bio/bila voljan/a ili spreman/a na konstruktivno rješavanje sukoba, to bi mi otežalo konstruktivno komuniciranje prilikom sukoba.

\begin{tabular}{ccccccc}
$\begin{array}{c}\text { U potpunosti se } \\
\text { ne slažem } \\
1\end{array}$ & 2 & 3 & 4 & 5 & \multicolumn{2}{c}{$\begin{array}{c}\text { U potpunosti se } \\
\text { slažem }\end{array}$} \\
\hdashline & 0 & 0 & 0 & 0
\end{tabular}

67. Koliko često Vaš/a partner/ica nije voljan/a ili spremna na konstruktivno rješavanje sukoba? Jako rijetko

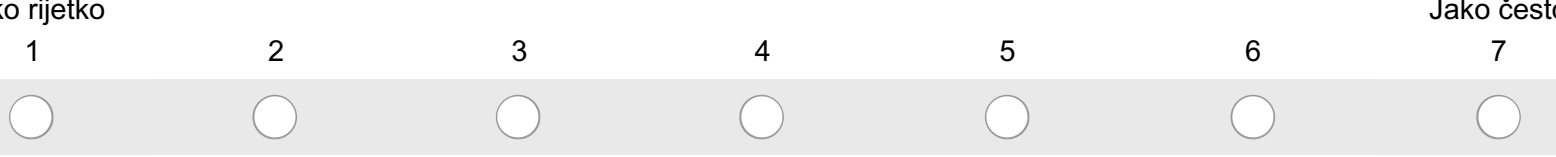

68. Kada se ne bih znao/la konstruktivno ponašati prilikom sukoba, to bi mi otežalo konstruktivno komuniciranje prilikom sukoba.

\begin{tabular}{ccccccc}
$\begin{array}{c}\text { U potpunosti se } \\
\text { ne slažem } \\
1\end{array}$ & 2 & 3 & 4 & 5 & \multicolumn{2}{c}{$\begin{array}{c}\text { U potpunosti se } \\
\text { slažem }\end{array}$} \\
\hline & 0 & 0 & 0 & 0
\end{tabular}

69. Koliko često se Vi ne znate konstruktivno ponašati prilikom sukoba?

$\begin{array}{ccccccc}\text { Jako rijetko } \\ 1 & 2 & 3 & 4 & 5 & 6 & \text { Jako često } \\ 0 & 0 & 0 & 0 & 0\end{array}$

70. Kada bi druge osobe bile prisutne i uplitale se u sukobe između moje/g partnera/ice i mene, to bi mi otežalo konstruktivno komuniciranje prilikom sukoba.

\begin{tabular}{ccccccc}
$\begin{array}{c}\text { U potpunosti se } \\
\text { ne slažem } \\
1\end{array}$ & 2 & 3 & 4 & 5 & \multicolumn{2}{c}{$\begin{array}{c}\text { U potpunosti se } \\
\text { slažem }\end{array}$} \\
& 0 & 0 & 0 & 0
\end{tabular}

71. Koliko često prisutnost i uplitanje drugih osoba ometa rješavanje sukoba između Vas i Vaše/g partnera/ice?

$\begin{array}{cccccc}\begin{array}{c}\text { Jako rijetko } \\ 1\end{array} & 2 & 3 & 4 & 5 & 6 \\ 7 & 0 & 0 & 0\end{array}$


79. Jesu li Vam Vaše ŽENSKE PRIJATELJICE uzor kako se treba ponašati u vezi? Sigurno ne

$\begin{array}{lllllll}2 & 3 & 4 & 5 & 6 & 7 & 0 \\ 0 & 0 & 0 & 0\end{array}$

80. Mislite li da će Vaši RODITELJI prilikom budućih međusobnih sukoba komunicirati konstruktivno? Sigurno ne

1

$\bigcirc$
2

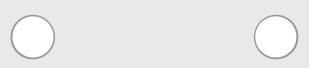

3

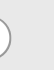

4

5

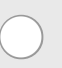

Sigurno da

6

7

81. Jesu li Vam Vaši RODITELJI uzor kako se treba ponašati u vezi?

Sigurno ne

1

0
2

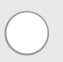

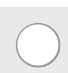

4

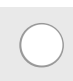

5

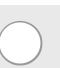

Sigurno da

6

7

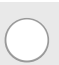

82. Mislite li da će VAŠ/A PARTNER/ICA u budućnosti komunicirati konstruktivno prilikom sukoba?

Sigurno ne

1

$\bigcirc$
2

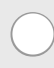

3

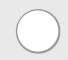

4

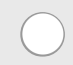

5

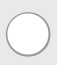

Sigurno da

6 7

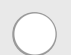

83. Je li Vam VAŠ/A PARTNER/ICA uzor kako se treba ponašati u vezi? Sigurno ne

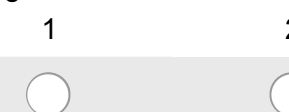

2

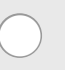

3

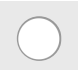

4

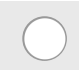

6

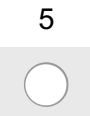

Sigurno da

7

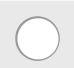

84. Mislite li da će Vaši KOLEGE u budućnosti komunicirati konstruktivno prilikom sukoba? Sigurno ne

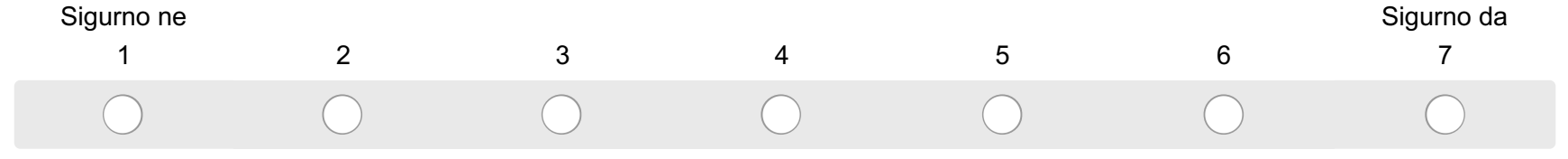

85. Jesu li Vam Vaši KOLEGE uzor kako se treba ponašati u vezi?

Sigurno ne

1

1

2

\begin{abstract}
3
\end{abstract}
4

O

Sigurno da

6

7 


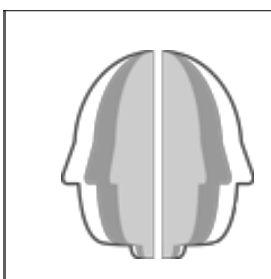

\section{Sukobi u vezama_1}

Ovaj upitnik opisuje nekoliko mogućih postupaka Vašeg/e partnera/ice. Zamislite da Vaš/a partner/ica izvodi pojedino ponašanje, a zatim pročitajte izjave koje slijede. Molimo Vas da odaberete kružić ispod broja koji najbolje odgovara tome koliko se slažete ili ne slažete s pojedinom izjavom 
86. VAŠ/A PARTNER/ICA KRITIZIRA NEŠTO ŠTO STE REKLI

\section{Uopće se ne \\ slažem}

1
Donekle se ne slažem

3
Donekle se slažem
4

U potpunosti se slažem

Ponašanje

moje/g partnera/ice je

takvo zbog nje/ga

same/og (npr. takav je tip

osobe, njezino/njegovo

trenutno raspoloženje).

Ponašanje moje/g partnera/ice je takvo zbog mene (npr. kakav sam tip osobe, moje trenutno raspoloženje).

Nije vjerojatno da će se razlog zbog kojeg me partner/ica kritizirao/la promijeniti.

Razlog zbog kojeg me partner/ica kritizirao/la je nešto što utječe i na druga područja naše veze.

Moj/a partner/ica me kritizirao/la namjerno, nije to napravio/la nesvjesno.

Ponašanje moje/g partnera/ice bilo je motivirano sebičnim, a ne nesebičnim razlozima.

Moj/a partner/ica zaslužuje da ju/ga krivim što me kritizirala.

2
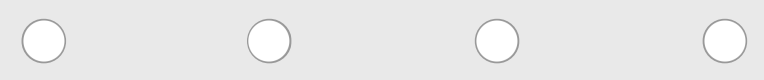

Slažem se

5

6 
87. VAŠ/A PARTNER/ICA POČINJE PROVODITI MANJE VREMENA S VAMA

\section{Uopće se ne \\ slažem}

1
Ne slažem se

2
Donekle se ne slažem

3
Donekle se slažem
4

U potpunosti se slažem

Ponašanje moje/g partnera/ice je takvo zbog nje same (npr. takav je tip osobe, njezino trenutno raspoloženje).

Ponašanje moje/g partnera/ice je takvo zbog mene (npr. kakav sam tip osobe, moje trenutno raspoloženje).

Nije vjerojatno da će se razlog zbog kojeg je partner/ica počeo/la provoditi manje vremena sa mnom promijeniti.

Razlog zbog kojeg je $\mathrm{moj} / \mathrm{a}$

partner/ica počeo/la provoditi manje vremena sa mnom je nešto što utječe i na druga područja naše veze.

Moj/a partner/ica je počeo/la provoditi manje vremena sa mnom namjerno, za razliku od nenamjerno.

Ponašanje moje/g partnera/ice bilo je motivirano sebičnim, za razliku od nesebičnih pobuda.

Moj/a partner/ica zaslužuje da ga/ju krivim što je počeo/la provoditi manje vremena sa mnom.

\section{Slažem se}

5 
88. VAŠ/A PARTNER/ICA NE OBRAĆA POZORNOST NA ONO ŠTO GOVORITE.

\section{Uopće se ne \\ slažem}

1
Donekle se ne
slažem

3
Donekle se slažem

4
U potpunosti se slažem

Ponašanje moje/g partnera/ice je takvo zbog nje/ga same/og (npr. takav je tip osobe, njezino/njegovo trenutno raspoloženje).

Ponašanje moje/g partnera/ice je takvo zbog mene (npr. kakav sam tip osobe, moje trenutno raspoloženje).

Nije vjerojatno da će se razlog zbog kojeg moj/a partner/ica ne obraća pozornost na ono što govorim promijeniti.

Razlog zbog kojeg moj/a partner/ica ne obraća pozornost na ono što govorim je nešto što utječe i na druga područja naše veze.

Moj/a partner/ica ne obraća pozornost na ono što govorim namjerno,

za razliku od

nenamjerno.

Ponašanje moje/g partnera/ice bilo je motivirano sebičnim, za razliku od nesebičnih pobuda.

Moj/a partner/ica zaslužuje da ju/ga krivim što ne obraća pozornost na ono što govorim.

2
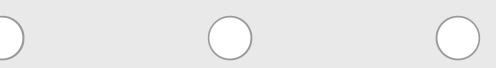

Slažem se

5

6 
89. VAŠ/A PARTNER/ICA SE DRŽI HLADNO I DISTANCIRANO

\section{Uopće se ne \\ slažem}

1

Ne slažem se
Donekle se ne slažem

3

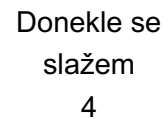

4
U potpunosti se slažem

Ponašanje moje/g partnera/ice je takvo zbog nje/ga same/og (npr. takav je tip osobe, njezino/njegovo trenutno raspoloženje).

Ponašanje moje/g partnera/ice je takvo zbog mene (npr. kakav sam tip osobe, moje trenutno raspoloženje).

Nije vjerojatno da će se razlog zbog kojeg je moj/a

partner/ica hladan/a i distanciran/a promijeniti.

Razlog zbog kojeg je $\mathrm{moj} / \mathrm{a}$ partner/ica hladan/a i distanciran/a je nešto što utječe i na druga područja naše veze.

Moj/a partner/ica je hladan/a i distanciran/a namjerno, za razliku od nenamjerno.

Ponašanje moje/g partnera/ice bilo je motivirano sebičnim, za razliku od nesebičnih pobuda.

Moj/a partner/ica zaslužuje da ju/ga krivim što je hladan/a i distanciran/a. 


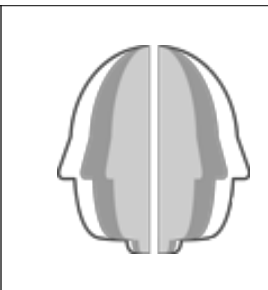

\section{Sukobi u vezama_1}

90. Molimo Vas da označite u kojoj mjeri se slažete ili ne slažete sa sljedećim izjavama koje se odnose na neslaganja i konflikte koji se javljaju između Vas i Vaše/g partnera/ice, pri čemu 1 znači da se uopće ne slažete, a 7 da se u potpunosti slažete.

3

4

5

7

Imam malo kontrole nad problemima koji se javljaju između mojeg partnera/ice i mene.

Ne postoji mogućnost da riješim neke od problema koji se javljaju u mojoj vezi.

Kad se potrudim mogu riješiti gotovo svaku nesuglasicu koja se javi između mene i mog partnera/ice.

Često se osjećam bespomoćno kad je u pitanju nošenje s problemima koji se javljaju u mojoj vezi.

Ponekad se osjećam kao da moje mišljenje o problemima koji uzrokuju konflikte između nas nije važno.

Mogu napraviti stvari potrebne da bi se riješili naši problemi.

Malo toga mogu učiniti kako bih riješio mnoge od važnih problema između moje/g partnera/ice i sebe. 


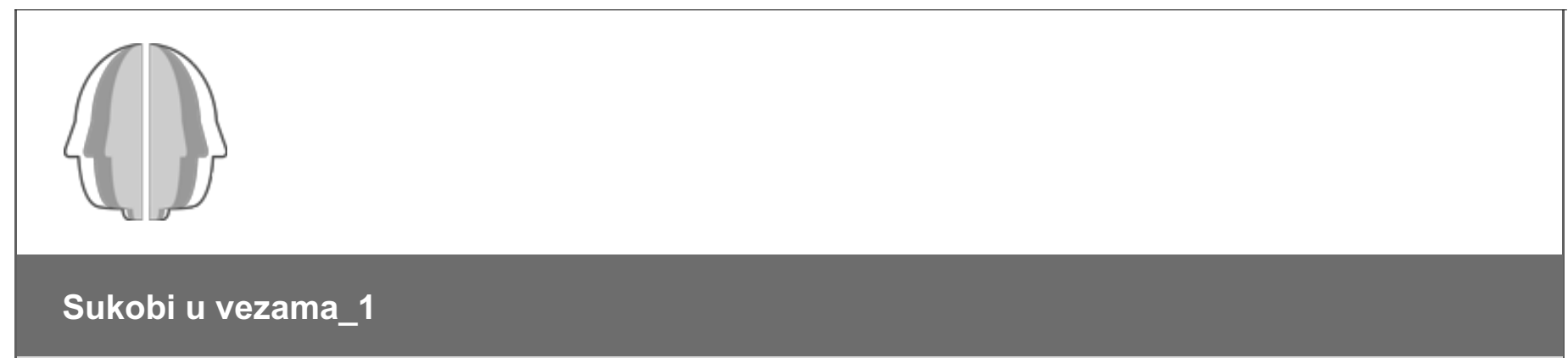

Hvala na dosadašnjem trudu, još samo 15-ak minuta! 


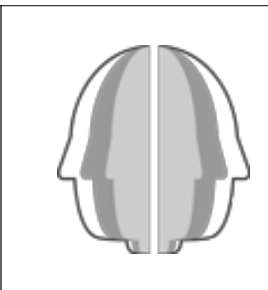

\section{Sukobi u vezama_1}

91. Pročitajte svaku tvrdnju i, najiskrenije što možete, odgovorite na pitanje: U KOJOJ MJERI SE ONO ŠTO TVRDNJA IZRAŽAVA ODNOSI NA MENE? Označite svoj odgovor, imajući na umu skalu s vrha tablice. MOLIMO VAS DA ODGOVORITE NA SVAKO PITANJE!
Uopće se ne odnosi na mene
1

\section{Podjednako se}

odnosi i ne odnosi na mene

3
U potpunosti se odnosi na mene

4

1. Vjerujem da je druženje radi zabave $\mathrm{s}$ prijateljima jedno od važnih životnih zadovoljstava

2. Poznati prizori, zvukovi i mirisi iz djetinjstva često mi donose bujicu predivnih uspomena

3. Sudbina određuje velik dio mog života

4. Često razmišljam o tome što sam sve tijekom života trebao napraviti drugačije

5. Donosim odluke uglavnom pod utjecajem osoba i stvari koje me okružuju

6. Vjerujem da bi dan trebalo svakoga jutra unaprijed isplanirati

7. Ugodno mi je razmišljati o vlastitoj prošlosti

8. Ponašam se impulzivno 


\begin{tabular}{|c|c|c|c|c|c|}
\hline & $\begin{array}{l}\text { Uopće se ne odnosi } \\
\text { na mene } \\
1\end{array}$ & 2 & $\begin{array}{l}\text { Podjednako se } \\
\text { odnosi i ne odnosi } \\
\text { na mene } \\
3\end{array}$ & 4 & $\begin{array}{l}\text { U potpunosti se } \\
\text { odnosi na mene }\end{array}$ \\
\hline \multicolumn{6}{|l|}{$\begin{array}{l}\text { 9. Ne brinem se ukoliko } \\
\text { stvari nisu obavljene na } \\
\text { vrijeme }\end{array}$} \\
\hline \multicolumn{6}{|l|}{$\begin{array}{l}\text { 10. Kada nešto želim } \\
\text { postići, točno postavim } \\
\text { ciljeve i razmotrim kako } \\
\text { ih mogu ostvariti }\end{array}$} \\
\hline \multicolumn{6}{|l|}{$\begin{array}{l}\text { 11. Sve u svemu, u } \\
\text { mojoj prošlosti ima puno } \\
\text { više dobrih nego loših } \\
\text { iskustava }\end{array}$} \\
\hline \multicolumn{6}{|l|}{$\begin{array}{l}\text { 12. Dok slušam svoju } \\
\text { omiljenu glazbu, često } \\
\text { mi se dogodi da u } \\
\text { potpunosti izgubim } \\
\text { pojam o vremenu }\end{array}$} \\
\hline \multicolumn{6}{|l|}{$\begin{array}{l}\text { 13. Poštivanje rokova i } \\
\text { ispunjavanje obaveza } \\
\text { dolazi prije zabave }\end{array}$} \\
\hline \multicolumn{6}{|l|}{$\begin{array}{l}\text { 14. Bit će što bude, bez } \\
\text { obzira što ja radim }\end{array}$} \\
\hline \multicolumn{6}{|l|}{$\begin{array}{l}\text { 15. Uživam u pričama o } \\
\text { tome kako je bilo u } \\
\text { 'dobra stara vremena' }\end{array}$} \\
\hline \multicolumn{6}{|l|}{$\begin{array}{l}\text { 16. Bolna iskustva iz } \\
\text { prošlosti često se } \\
\text { ponavljaju u mojim } \\
\text { mislima }\end{array}$} \\
\hline \multicolumn{6}{|l|}{$\begin{array}{l}\text { 17. Nastojim živjeti što } \\
\text { potpunije, dan za danom }\end{array}$} \\
\hline \multicolumn{6}{|l|}{$\begin{array}{l}\text { 18. Uzrujava me kada } \\
\text { kasnim na sastanke i } \\
\text { dogovore }\end{array}$} \\
\hline \multicolumn{6}{|l|}{$\begin{array}{l}\text { 19. Kad bih mogao, živio } \\
\text { bih svaki dan kao da mi } \\
\text { je posljednji }\end{array}$} \\
\hline \multicolumn{6}{|l|}{$\begin{array}{l}\text { 20. Sjećanja na dobra } \\
\text { vremena lako mi padaju } \\
\text { na pamet }\end{array}$} \\
\hline $\begin{array}{l}\text { 21. Svoje obaveze } \\
\text { prema prijateljima i } \\
\text { nadređenima } \\
\text { ispunjavam na vrijeme }\end{array}$ & & & & & \\
\hline
\end{tabular}




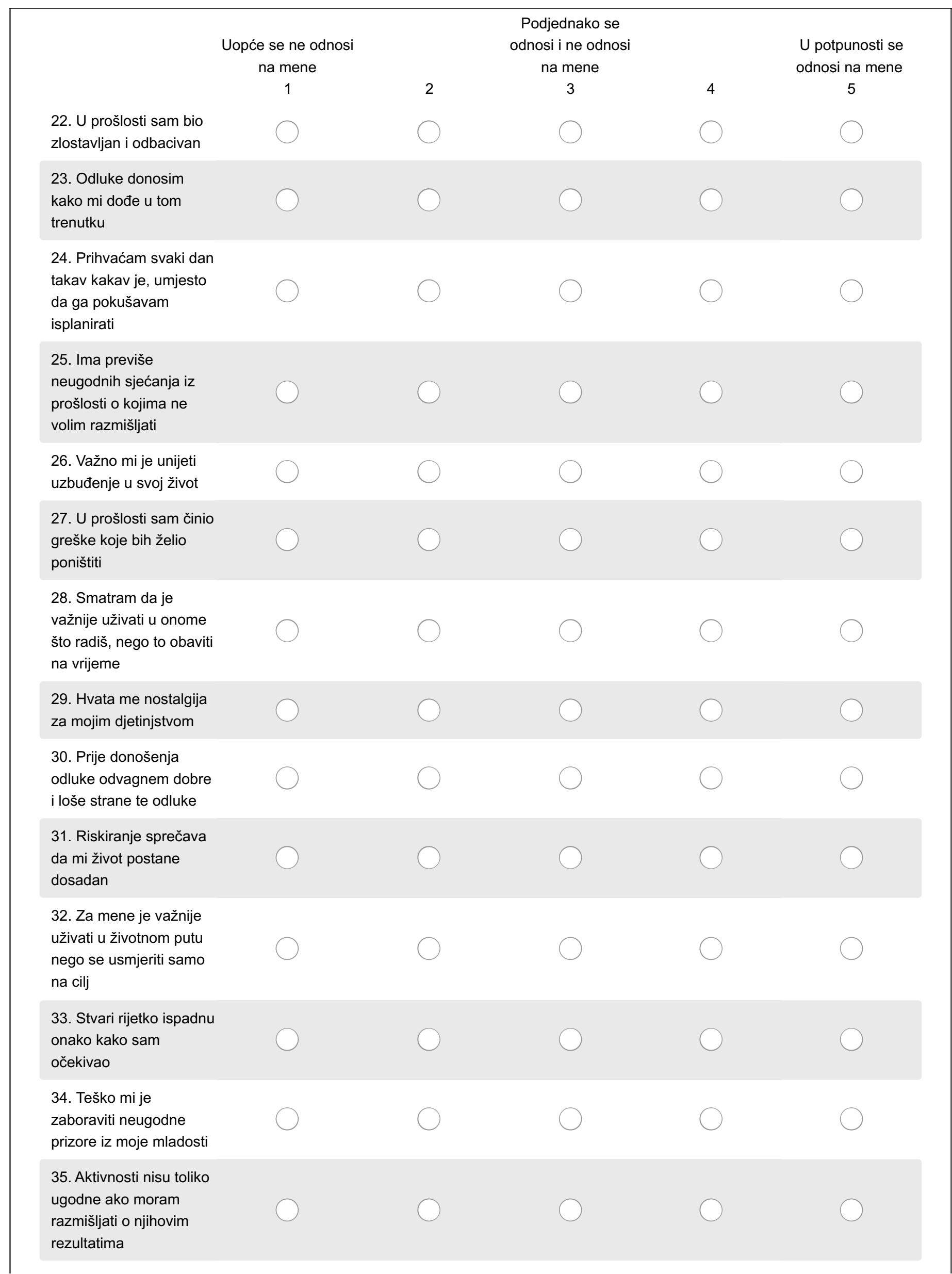


Uopće se ne odnosi

na mene

1

2
Podjednako se

odnosi i ne odnosi

na mene

3

4

U potpunosti se

odnosi na mene

5

36. Čak i kad uživam u sadašnjosti, ne mogu izbjeći usporedbe sa sličnim iskustvima iz prošlosti

37. Nije moguće stvarno planirati budućnost jer se stvari previše mijenjaju

38. Moj životni put kontroliraju sile na koje ne mogu utjecati

39. Nema smisla brinuti oko budućnosti kad ionako ni na što ne mogu utjecati

40. Završavam zadatke na vrijeme zahvaljujući svom redovitom radu

41. Često se isključim dok članovi moje obitelji razgovaraju o tome kako je nekad bilo

42. Volim riskirati kako bih unio uzbuđenje $u$ svoj život

43. Obično radim popis stvari koje trebam obaviti

44. Češće slijedim svoje srce nego glavu

45. Kada imam posla koji trebam obaviti sposoban sam odoljeti iskušenjima

46. Zna me ponijeti uzbuđenje trenutka

47. Današnji način Života je prekompliciran, više bi mi odgovarao jednostavniji život, kakav je bio u prošlosti 
Podjednako se

Uopće se ne odnosi na mene

1

2

odnosi i ne odnosi

na mene

3

4

U potpunosti se odnosi na mene

5

48. Više mi se sviđaju moji prijatelji koji su spontani nego oni predvidljivi

49. Volim obiteljske rituale i običaje koji se redovito ponavljaju

50. Razmišljam o lošim stvarima koje su mi se dogodile u prošlosti

51. Ustrajem u teškim i dosadnim zadacima ukoliko mi to može pomoći u napredovanju

52. Trošenje zarade na današnja zadovoljstva bolje je nego štednja za sigurnu budućnost

53. Sreća se često isplati više nego naporan rad

54. Razmišljam o dobrim stvarima koje sam propustio u svom životu

55. Volim kada su moji odnosi s bliskim osobama strastveni

56. Uvijek će biti vremena da uhvatim korak s poslom
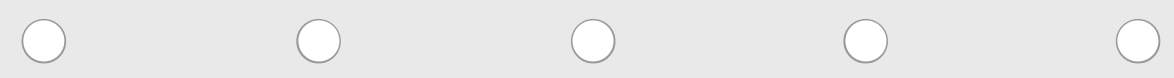


\section{()}

\section{Sukobi u vezama_1}

Pokušajte se sami zamisliti u situacijama koje slijede. Kad biste se našli u takvoj situaciji, što biste mislili da je uzrok? Događaji mogu biti izazvani različitim uzrocima, a mi tražimo od Vas da izaberete samo jedan, glavni, najvjerojatniji uzrok da se Vi nađete u takvoj opisanoj situaciji.

\section{SUSREĆETE PRIJATELJA I ON HVALI VAŠ IZGLED.}

92. Ovisi li taj uzrok o Vama i Vašim karakteristikama ili o nekim drugim osobama i okolnostima?

Potpuno ovisi o

drugim ljudima i

okolnostima

$$
1
$$

2

3

4

5
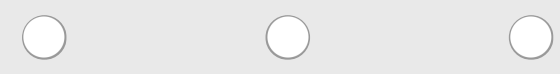

93. Hoće li taj uzrok biti prisutan i u nekoj budućoj sličnoj situaciji?

Nikad više neće

biti prisutan

$\begin{array}{lllllll}1 & 2 & 3 & 4 & 5 & 6 & 7 \\ 0 & 0 & 0 & 0\end{array}$

94. Je li taj uzrok nešto što utječe samo na ovu situaciju ili može utjecati i na druge situacije u Vašem životu?

$$
\begin{aligned}
& \text { Utječe samo na } \\
& \text { ovu konkretnu } \\
& \text { situaciju }
\end{aligned}
$$

1

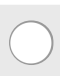

2

3

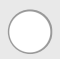

Utječe na sve situacije u mom

životu

6

7
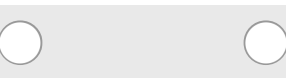

Potpuno ovisi o

meni

7

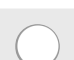

vijek će biti

risutan

95. Da Vam se dogodi ovakva situacija, koliko bi Vam bila važna?

Uopće mi ne bi

bila važna

1
2

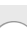

3

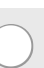

Bila bi mi osobito

važna

7 


\section{0}

\section{Sukobi u vezama_1}

\section{VEĆ NEKO VRIJEME BEZUSPJEŠNO POKUŠAVATE NAĆI POSAO.}

96. Ovisi li taj uzrok o Vama i Vašim karakteristikama ili o nekim drugim osobama i okolnostima?

Potpuno ovisi o

drugim ljudima i

Potpuno ovisi o

okolnostima

3

4

5

meni

1

2
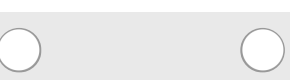

6

7

97. Hoće li taj uzrok biti prisutan i u nekoj budućoj sličnoj situaciji?

Nikad više neće

Uvijek će biti

biti prisutan

3

4

5

prisutan

$\begin{array}{lllllll}1 & 3 & 4 & 5 & 6 & 7 & 6 \\ 0 & 0 & 0 & 0\end{array}$

98. Je li taj uzrok nešto što utječe samo na ovu situaciju ili može utjecati i na druge situacije u Vašem životu?

Utječe samo na

ovu konkretnu situaciju

1 2

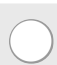

3

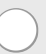

Utječe na sve situacije u mom životu 7

99. Da Vam se dogodi ovakva situacija, koliko bi Vam bila važna?

Uopće mi ne bi bila važna

1

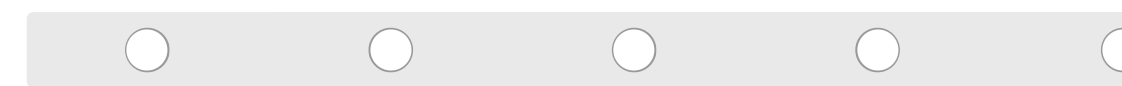

2

3

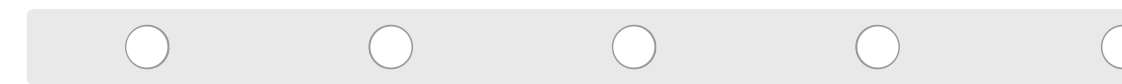

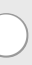

6

5

6

Bila bi mi osobito

važna

7 


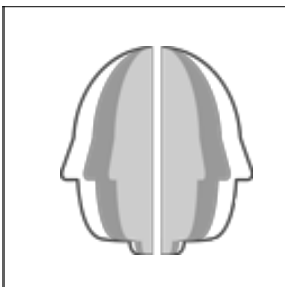

\section{Sukobi u vezama_1}

\section{POSTAJETE VRLO BOGATI.}

100. Ovisi li taj uzrok o Vama i Vašim karakteristikama ili o nekim drugim osobama i okolnostima?

Potpuno ovisi o

drugim ljudima i

okolnostima

3

2

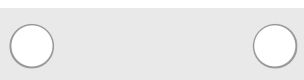

4

5

Potpuno ovisi o

O
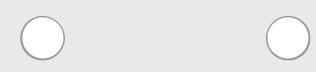

6

meni

7

101. Hoće li taj uzrok biti prisutan i u nekoj budućoj sličnoj situaciji?

Nikad više neće

biti prisutan

4

5

Uvijek će biti

1

2

0

0

0

6

7

102. Je li taj uzrok nešto što utječe samo na ovu situaciju ili može utjecati i na druge situacije u Vašem životu?

Utječe samo na

Utječe na sve

ovu konkretnu situaciju

1

2

3

4

5

situacije u mom
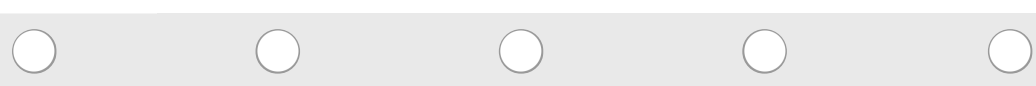

6

životu

7

103. Da Vam se dogodi ovakva situacija, koliko bi Vam bila važna?

Uopće mi ne bi
bila važna

1

0
2

3

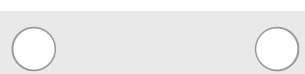

Bila bi mi osobito

važna

5

6

7 


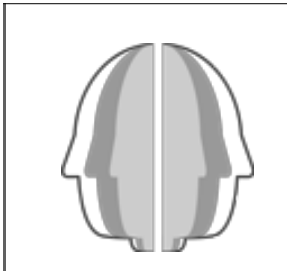

\section{Sukobi u vezama_1}

\section{DOLAZI VAM PRIJATELJ KOJI IMA PROBLEMA, A VI MU I NE POKUŠAVATE POMOĆI.}

104. Ovisi li taj uzrok o Vama i Vašim karakteristikama ili o nekim drugim osobama i okolnostima?

Potpuno ovisi o

drugim ljudima i

okolnostima

1

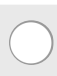

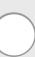

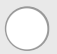

4

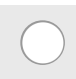

Potpuno ovisi o meni

6

7

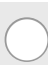

105. Hoće li taj uzrok biti prisutan i u nekoj budućoj sličnoj situaciji?

Nikad više neće

biti prisutan

1

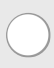
2

3

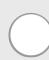

4

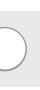

Uvijek će biti prisutan

6

7

106. Je li taj uzrok nešto što utječe samo na ovu situaciju ili može utjecati i na druge situacije u Vašem životu?

Utječe samo na

ovu konkretnu

situaciju

1

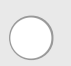

2

3

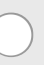

4

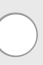

Utječe na sve situacije u mom životu

6 7

107. Da Vam se dogodi ovakva situacija, koliko bi Vam bila važna?

Uopće mi ne bi bila važna

1

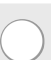

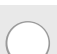

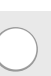

Bila bi mi osobito važna

6

7 


\section{0}

\section{Sukobi u vezama_1}

\section{ODRŽITE VAŽAN GOVOR PRED SKUPINOM LJUDI, A ONI NA GOVOR NEGATIVNO REAGIRAJU.}

108. Ovisi li taj uzrok o Vama i Vašim karakteristikama ili o nekim drugim osobama i okolnostima?

Potpuno ovisi o

drugim ljudima i

okolnostima

1

2

5

Potpuno ovisi o
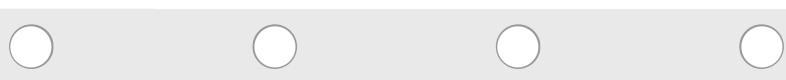

men

109. Hoće li taj uzrok biti prisutan i u nekoj budućoj sličnoj situaciji?

Nikad više neće

Uvijek će biti

biti prisutan

2

3

4

5

6

prisutan
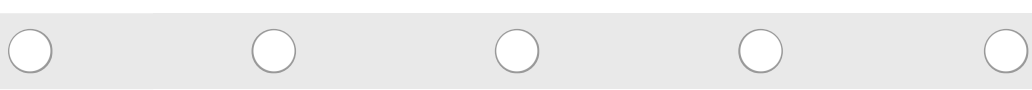

110. Je li taj uzrok nešto što utječe samo na ovu situaciju ili može utjecati i na druge situacije u Vašem životu?

Utječe samo na

ovu konkretnu

situaciju

1

2

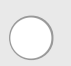

3

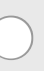

4

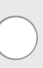

Utječe na sve situacije u mom životu

6

7

111. Da Vam se dogodi ovakva situacija, koliko bi Vam bila važna?

Uopće mi ne bi bila važna

1

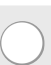

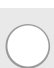

5

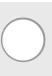

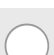

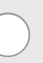

7

7

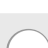




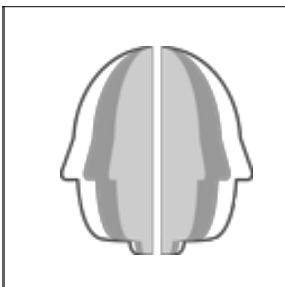

\section{Sukobi u vezama_1}

\section{RADITE NA PROJEKTU KOJI JE VRLO DOBRO OCIJENJEN.}

112. Ovisi li taj uzrok o Vama i Vašim karakteristikama ili o nekim drugim osobama i okolnostima?

Potpuno ovisi o

drugim ljudima $\mathrm{i}$

okolnostima

4

5

Potpuno ovisi o

1

2
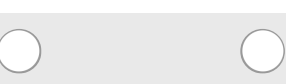

6

meni
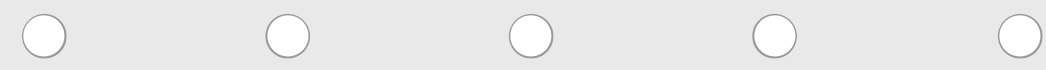

7

113. Hoće li taj uzrok biti prisutan i u nekoj budućoj sličnoj situaciji?

Nikad više neće

biti prisutan

1

2

3

4

5

Uvijek će biti

prisutan

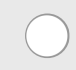

$\bigcirc$
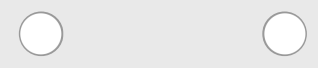

6

7

114. Je li taj uzrok nešto što utječe samo na ovu situaciju ili može utjecati i na druge situacije u Vašem životu?

Utječe samo na
ovu konkretnu
situaciju

1

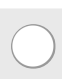

2

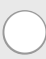

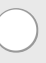

Utječe na sve situacije u mom životu

6 7

115. Da Vam se dogodi ovakva situacija, koliko bi Vam bila važna?

Uopće mi ne bi

bila važna

1

0
2

3
4

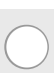

Bila bi mi osobito

važna

6

7 


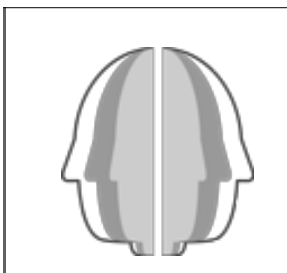

\section{Sukobi u vezama_1}

\section{SUSREĆETE PRIJATELJA KOJI SE PREMA VAMA NEPRIJATELJSKI ODNOSI.}

116. Ovisi li taj uzrok o Vama i Vašim karakteristikama ili o nekim drugim osobama i okolnostima?

Potpuno ovisi o

drugim ljudima i okolnostima

$$
1
$$

2

3

4

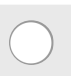

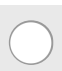

Potpuno ovisi o

meni

6

7

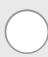

117. Hoće li taj uzrok biti prisutan i u nekoj budućoj sličnoj situaciji?

Nikad više neće

biti prisutan

1

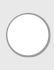

2

3

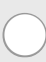

4

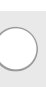

Uvijek će biti prisutan

6

7

118. Je li taj uzrok nešto što utječe samo na ovu situaciju ili može utjecati i na druge situacije u Vašem Životu?

Utječe samo na

ovu konkretnu

situaciju

1

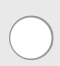

3

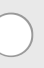

4

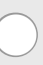

Utječe na sve situacije u mom životu

6 7

119. Da Vam se dogodi ovakva situacija, koliko bi Vam bila važna?

\section{Uopće mi ne bi} bila važna

1

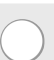

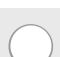

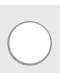

Bila bi mi osobito važna

6

7 


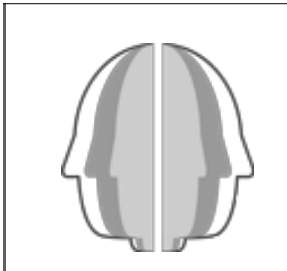

\section{Sukobi u vezama_1}

\section{NE USPIJEVATE OBAVITI SAV POSAO KOJI OKOLINA OČEKUJE DA ĆETE OBAVITI.}

120. Ovisi li taj uzrok o Vama i Vašim karakteristikama ili o nekim drugim osobama i okolnostima?

Potpuno ovisi o

drugim ljudima i okolnostima

$$
1
$$

2

3

4

5

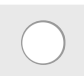

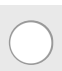

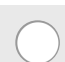

Potpuno ovisi o

meni

6

7

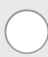

121. Hoće li taj uzrok biti prisutan i u nekoj budućoj sličnoj situaciji?

Nikad više neće

Uvijek će biti

biti prisutan

2

3

4

5

6

prisutan
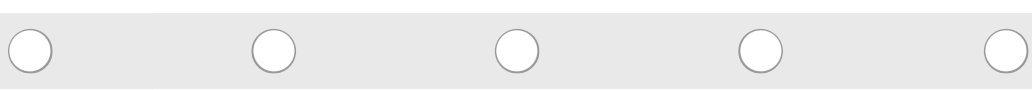

7

122. Je li taj uzrok nešto što utječe samo na ovu situaciju ili može utjecati i na druge situacije u Vašem životu?

Utječe samo na

ovu konkretnu

situaciju

1

2

3

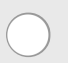

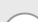

4

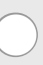

Utječe na sve situacije u mom životu

7

$\bigcirc$

123. Da Vam se dogodi ovakva situacija, koliko bi Vam bila važna?

\section{Uopće mi ne bi}

bila važna

1

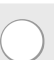

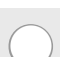

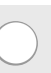

Bila bi mi osobito

važna

6

7 


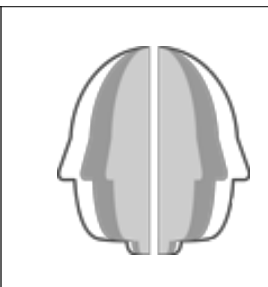

\section{Sukobi u vezama_1}

\section{VAŠ VAM JE PARTNER/ICA NAKLONJENIJI/A NEGO PRIJE.}

124. Ovisi li taj uzrok o Vama i Vašim karakteristikama ili o nekim drugim osobama i okolnostima?

Potpuno ovisi o

drugim ljudima $\mathrm{i}$

okolnostima

4

5

Potpuno ovisi o

1

2
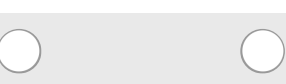

6

meni
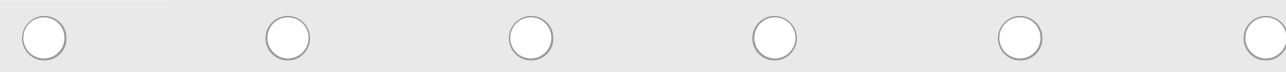

7

125. Hoće li taj uzrok biti prisutan i u nekoj budućoj sličnoj situaciji?

Nikad više neće

biti prisutan

1

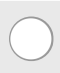

2

$\bigcirc$

3

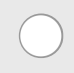

4

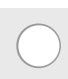

Uvijek će biti prisutan

7

126. Je li taj uzrok nešto što utječe samo na ovu situaciju ili može utjecati i na druge situacije u Vašem životu?

Utječe samo na
ovu konkretnu
situaciju

1

$\bigcirc$
2

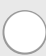

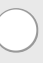

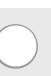

Utječe na sve situacije u mom životu

6

7

127. Da Vam se dogodi ovakva situacija, koliko bi Vam bila važna?

Uopće mi ne bi

bila važna

1

O
2

3
4

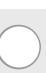

Bila bi mi osobito

važna

6

7 


\section{()}

\section{Sukobi u vezama_1}

\section{PRIJAVLJUJETE SE ZA MJESTO KOJE ZAISTA ŽELITE DOBITI (npr. važan posao, upis na željeni fakultet) I DOBIVATE GA}

128. Ovisi li taj uzrok o Vama i Vašim karakteristikama ili o nekim drugim osobama i okolnostima?

Potpuno ovisi o

drugim ljudima i

okolnostima

$$
1
$$

2

3

4

5

Potpuno ovisi o
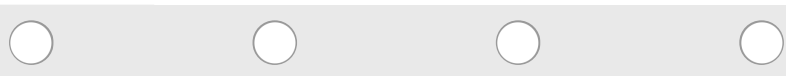

men

129. Hoće li taj uzrok biti prisutan i u nekoj budućoj sličnoj situaciji?

Nikad više neće

biti prisutan

2

3

4

5

Uvijek će biti

1

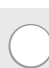

$\bigcirc$

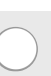

6

prisutan

7

130. Je li taj uzrok nešto što utječe samo na ovu situaciju ili može utjecati i na druge situacije u Vašem Životu?

Utječe samo na

ovu konkretnu

situaciju

1

2

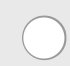

3

4

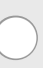

Utječe na sve situacije u mom životu

7

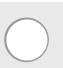

131. Da Vam se dogodi ovakva situacija, koliko bi Vam bila važna?

Uopće mi ne bi

bila važna

1

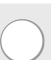

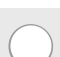

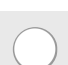

Bila bi mi osobito

važna

6

7 


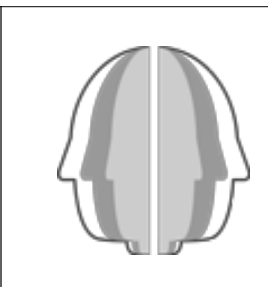

\section{Sukobi u vezama_1}

\section{ODLAZITE NA „SPOJ“ KOJI LOŠE PROTIČE.}

132. Ovisi li taj uzrok o Vama i Vašim karakteristikama ili o nekim drugim osobama i okolnostima?

Potpuno ovisi o

drugim ljudima i

okolnostima

3

2

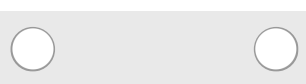

4

5

Potpuno ovisi o

O

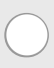

6

meni

7

133. Hoće li taj uzrok biti prisutan i u nekoj budućoj sličnoj situaciji?

Nikad više neće

biti prisutan

1

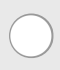

2

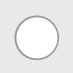

3

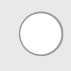

4

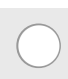

Uvijek će biti prisutan

7

134. Je li taj uzrok nešto što utječe samo na ovu situaciju ili može utjecati i na druge situacije u Vašem životu?

Utječe samo na
ovu konkretnu
situaciju

1

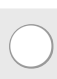

2

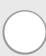

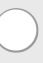

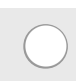

Utječe na sve situacije u mom životu

6

135. Da Vam se dogodi ovakva situacija, koliko bi Vam bila važna?

Uopće mi ne bi

bila važna

1

$\bigcirc$
2

3
4

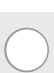

Bila bi mi osobito

važna

6

7 


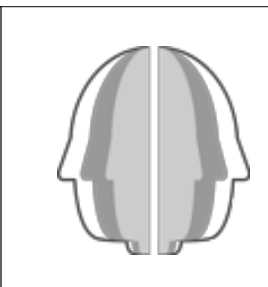

\section{Sukobi u vezama_1}

\section{DOBIVATE POVIŠICU PLAĆE.}

136. Ovisi li taj uzrok o Vama i Vašim karakteristikama ili o nekim drugim osobama i okolnostima?

Potpuno ovisi o

drugim ljudima i

okolnostima

3

2

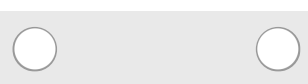

4

5

Potpuno ovisi o

(2)
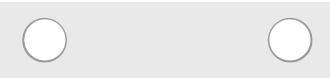

6

meni

7

137. Hoće li taj uzrok biti prisutan i u nekoj budućoj sličnoj situaciji?

Nikad više neće

biti prisutan

1

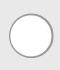

2

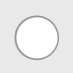

3

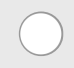

4

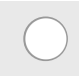

Uvijek će biti prisutan

7

138. Je li taj uzrok nešto što utječe samo na ovu situaciju ili može utjecati i na druge situacije u Vašem životu?

Utječe samo na
ovu konkretnu
situaciju

1

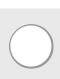

2

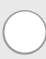

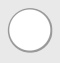

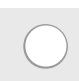

Utječe na sve situacije u mom životu

6

7

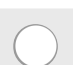

139. Da Vam se dogodi ovakva situacija, koliko bi Vam bila važna?

Uopće mi ne bi

bila važna

1

0
2
4

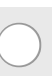

Bila bi mi osobito

važna

7 


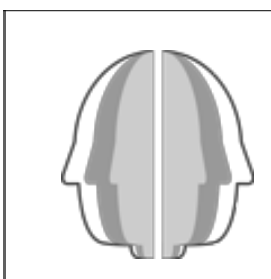

\section{Sukobi u vezama_1}

Hvala Vam što ste sudjelovali u istraživanju i posvetili nam Vaše vrijeme. Za mjesec dana putem e-maila ćete primiti link za drugi, kraći upitnik. Vrlo nam je važno da prikupimo cjelovite podatke, pa Vas molimo da ispunite i taj drugi upitnik. U međuvremenu se za sva pitanja slobodno obratite na e-mail adresu tkrznari@ffzg.hr. 
Prilog 14. Konačna verzija upitnika korištenog u istraživanju u drugoj točki mjerenja, primijenjena putem sustava SurveyMonkey. 


\section{Sukobi u vezama_2}

1.

Poštovani,

hvala Vam što ste se pristali sudjelovati u istraživanju bliskih odnosa, koje provodi psihologinja Tina Krznarić u okviru svoje doktorske disertacije na poslijediplomskom doktorskom studiju psihologije na Filozofskom fakultetu u Zagrebu, pod mentorstvom prof. dr. sc. Željke Kamenov. U prvoj fazi istraživanja ispunili ste upitnik, a sada Vas molimo da odvojite 15-ak minuta i odgovorite na još neka pitanja. Budući da nam je iznimno važno imati podatke iz obje faze mjerenja, molimo Vas da ovaj upitnik ispunite do kraja.

Nigdje na upitniku ne trebate navoditi svoje ime i prezime ili druge osobne podatke pomoću kojih bi Vas bilo moguće identificirati te će Vaši odgovori biti spremljeni isključivo pod šifrom, a rezultati istraživanja bit će prikazivani isključivo na grupnoj razini i koristiti samo u znanstvene svrhe. Kako bismo mogli upariti Vaše odgovore u ovom upitniku s onima koje ste dali ranije, molimo Vas da na prvoj stranici upitnika upišete svoju šifru koju ste dobili od studenta - anketara. Šifra treba biti jednaka onoj koju ste upisali u upitnik pred mjesec dana. 


\section{Sukobi u vezama_2}

2.

* 1. Molimo Vas da upišete šifru ispitanika koju ste dobili putem e-maila od studenta - anketara. Šifra treba biti jednaka onoj koju ste upisali u upitnik pred mjesec dana.

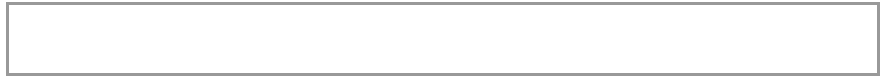

* 2. Spol:

muški

ženski

* 3. Jeste li još uvijek u ljubavnoj vezi s istom osobom s kojom ste bili prilikom ispunjavanja prvog upitnika?

$\mathrm{Da}$

$\mathrm{Ne}$ 
Sukobi u vezama_2

3.

4. Prije koliko dana ste prekinuli s partnerom?

* 5. Tko je prekinuo vezu?

Ja

Partner

Odluka je bila zajednička 


\section{Sukobi u vezama_2}

4.

6. Sljedeće tvrdnje odnose na Vašu vezu sa sadašnjim/om partnerom/icom. Molimo označite koliko se slažete s pojedinom tvrdnjom.

Zadovoljan/a sam našom vezom.
Moja veza je mnogo bolja od veza drugih ljudi.
Moja veza je gotovo idealna.
Naša veza me čini jako sretnim/om.
bliskosti, druženjem i slično.
Želim da naša veza jako dugo traje.
Predan/a sam održavanju veze sa svojim/om
partnerom/icom.

Ne bih bio/bila jako uzrujan/a da naša veza u bliskoj budućnosti završi.

Vjerojatno ću tijekom sljedeće godine biti u vezi s nekim drugim tko nije moj trenutni parner/ica.

Jako sam vezan/a za naš odnos - vrlo snažno povezan/a sa svojim/om partner/icom.

Želim da naša veza traje zauvijek.

Usmjeren/a sam na dugoročnu budućnost naše veze (npr. zamišljam se sa svojim partnerom i za nekoliko godina).

Drugi muškarci/druge žene s kojima bih mogao/la biti (osim mog/moje partnera/ice) su mi vrlo privlačni.

Moje alternative našoj vezi (izlasci s nekim drugim, provođenje vremena s prijateljima ili samostalno) su gotovo idealne.

Da nisam u vezi sa svojim/om partnerom/icom bilo bi mi sasvim dobro jer bih našao/la drugu privlačnu osobu s kojom bih bio/la.

Privlače me alternative ovoj vezi (izlasci s nekim drugim, provođenje vremena s prijateljima ili samostalno). 


\section{Sukobi u vezama_2}

5.

Sljedeće tvrdnje opisuju ponašanja koja se uobičajeno javljaju kad se pojavi neki problem u vezi. Vaš zadatak je da za svaku dolje navedenu tvrdnju označite broj koji označava koliko često ste se Vi i Vaš partner ponašali na navedeni način kad ste bili suočeni s nekim problemom U PROTEKLIH MJESEC DANA.

7. Kad se u vezi pojavi neki problem

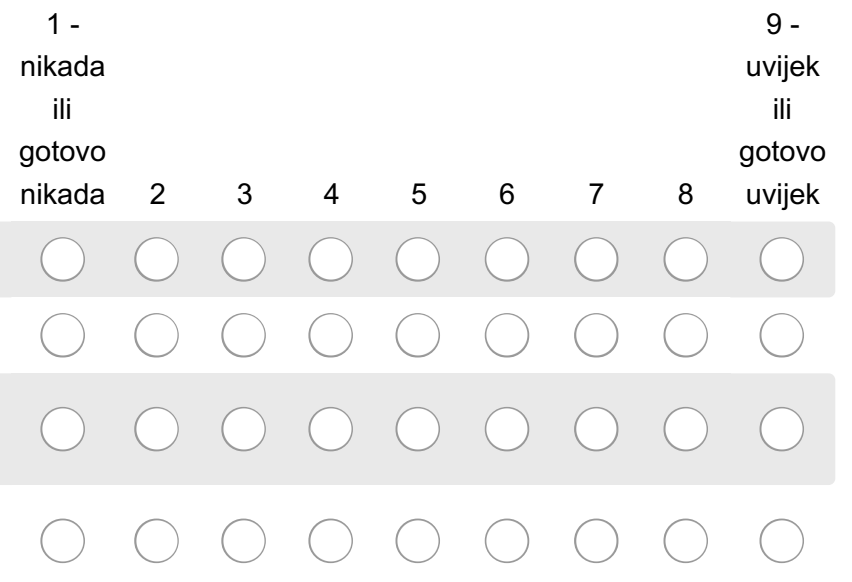
izbjeći raspravu. 
8. Tijekom rasprave o problemu u vezi,

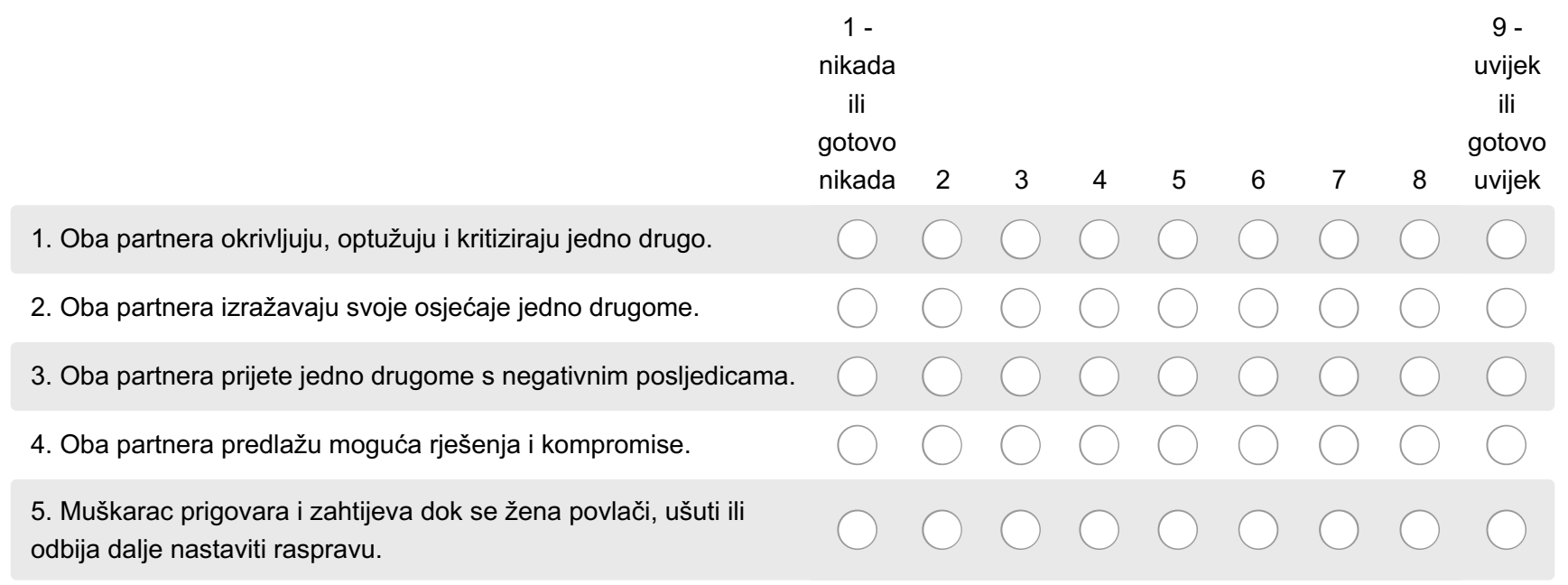

6. Žena prigovara i zahtijeva dok se muškarac povlači, ušuti ili odbija dalje nastaviti raspravu.

7. Muškarac kritizira, a žena se brani.

8. Žena kritizira, a muškarac se brani.

9. Muškarac vrši pritisak na ženu da počne ili prestane nešto činiti dok se žena tomu odupire.

10. Žena vrši pritisak na muškarca da počne ili prestane nešto činiti dok se muškarac tomu odupire.

11. Muškarac izražava osjećaje dok žena pokušava objasniti i nudi rješenja.

12. Žena izražava osjećaje dok muškarac pokušava objasniti i nudi rješenja.

13. Muškarac prijeti negativnim posljedicama, a žena popušta ili odustaje.

14. Žena prijeti negativnim posljedicama, a muškarac popušta ili odustaje.

15. Muškarac naziva ženu ružnim imenima, psuje ili napada njenu osobnost.

16. Žena naziva muškarca ružnim imenima, psuje ili napada njegovu osobnost.

17. Muškarac grubo odguruje, šamara ili udara ženu.

18. Žena grubo odguruje, šamara ili udara muškarca. 
9. Nakon rasprave o problemu u vezi,

1. Oba partnera smatraju da je druga osoba razumjela njihovo gledište.

$$
1-
$$

gotovo gotovo

$\begin{array}{lllllllll}\text { nikad } & 2 & 3 & 4 & 5 & 6 & 7 & 8 & \text { uvijek }\end{array}$

2. Oba se partnera povlače jedno od drugoga nakon rasprave.

3. Oba partnera smatraju da je problem riješen.

4. Nijedan partner ne popušta drugome nakon rasprave.

5. Oba partnera nakon rasprave pokušavaju biti posebno pažljivi prema drugome.

6. Muškarac se osjeća krivim zbog onog što je rekao ili napravio dok se žena osjeća povrijeđeno.

7. Žena se osjeća krivom zbog onog što je rekla ili napravila dok se muškarac osjeća povrijeđeno.

8. Muškarac pokušava biti posebno pažljiv i ponaša se kao da je sve u redu dok je žena hladna.

\section{9. Žena pokušava biti posebno pažljiva i ponaša se kao da je sve u} redu dok je muškarac hladan.

10. Muškarac zahtijeva da se žena ispriča ili obeća da će se više truditi dok se žena tomu opire.

11. Žena zahtijeva da se muškarac ispriča ili obeća da će se više truditi dok se muškarac tomu opire.

12. Muškarac traži podršku drugih osoba (roditelja, prijatelja...).

13. Žena traži podršku drugih osoba (roditelja, prijatelja...). 


\section{Sukobi u vezama_2}

6.

10. Sljedeće tvrdnje odnose se na Vaše osjećaje u ljubavnim vezama. Zanima nas kako se Vi

OPĆENITO osjećate u Vašim vezama s LJUBAVNIM PARTNERIMA, a ne što se događa u Vašoj trenutnoj vezi. Molimo Vas da pažljivo pročitate svaku tvrdnju i odgovorite u kojoj mjeri se slažete s tvrdnjom. Svoj stupanj slaganja sa svakom tvrdnjom izrazite odabirom odgovarajućeg broja na skali od 1 do 7 . Ispitivanje je anonimno pa Vas molimo da budete iskreni.

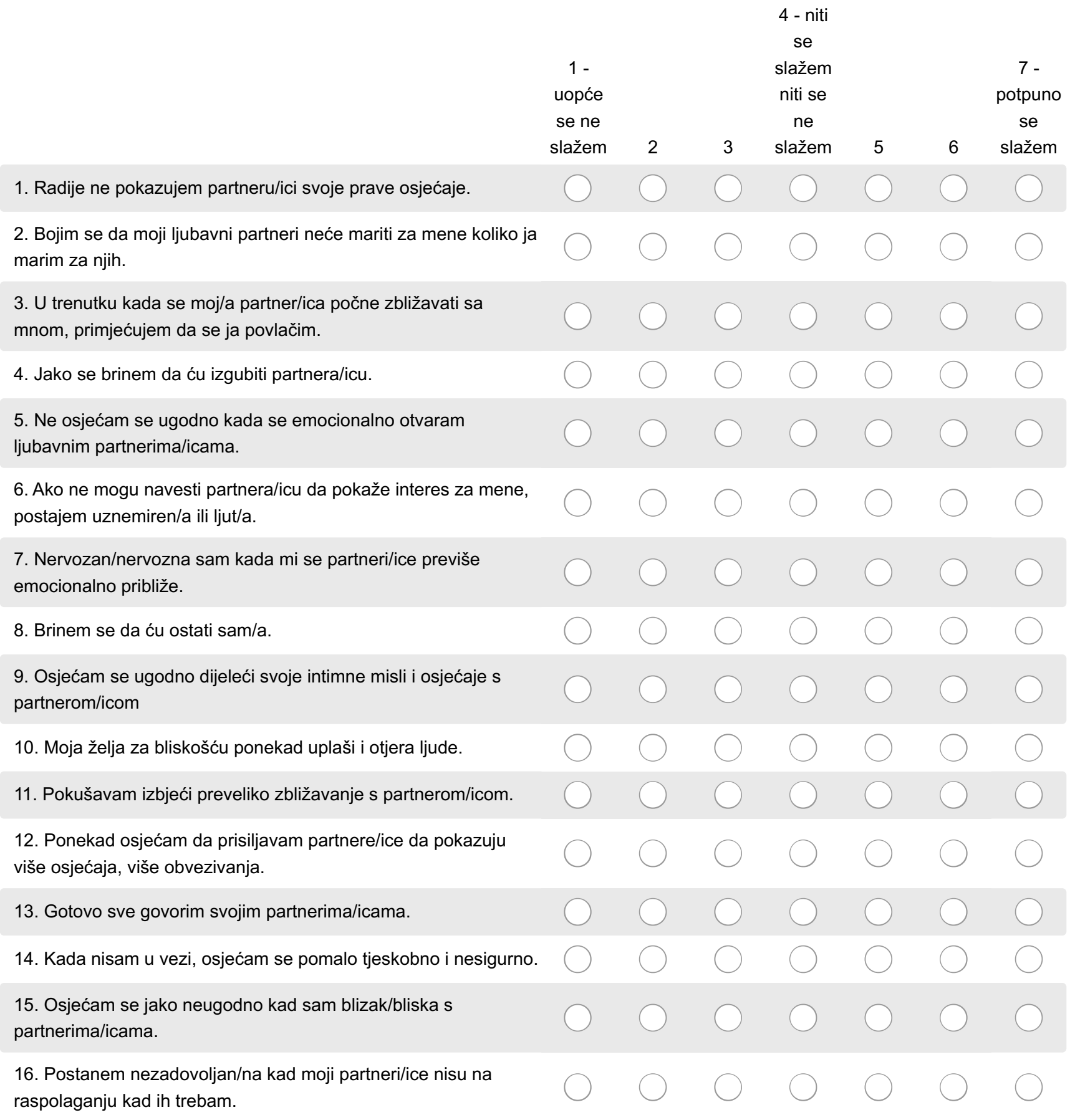




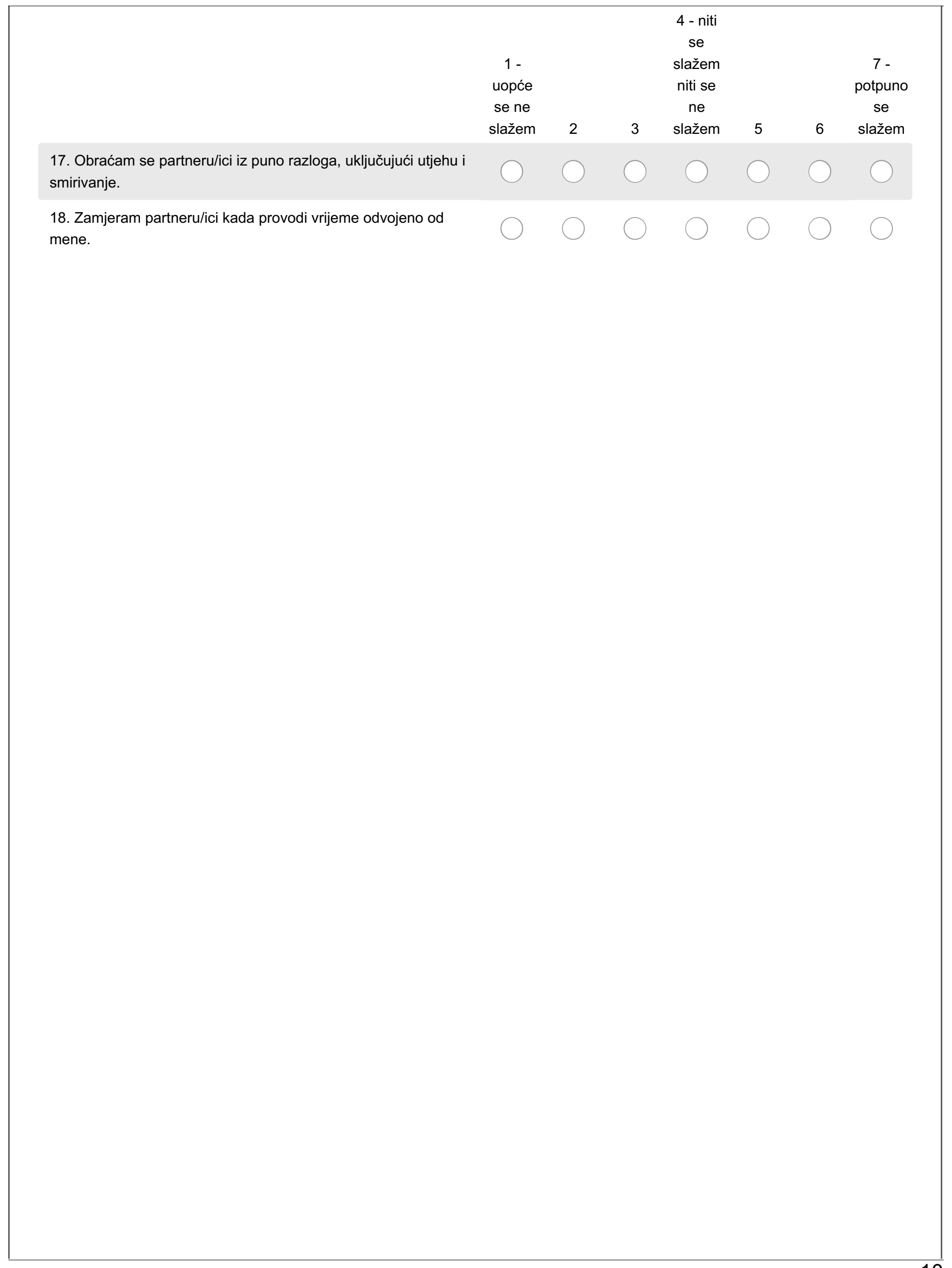




\section{Sukobi u vezama_2}

7.

11. U ovom dijelu upitnika slijede pitanja koja se odnose općenito na Vaša emocionalna stanja, doživljaje i načine reagiranja u određenim situacijama.

Molimo Vas da odredite kvalitetu svakog od dolje navedenih životnih područja na način da procijenite kakva su bila Vaša iskustva unutar svakog od tih područja U POSLJEDNJIH MJESEC DANA. Pored svakog životnog područja označite broj koji najbolje opisuje doživljene okolnosti.

\begin{tabular}{|c|c|c|c|c|c|c|c|c|c|}
\hline & $\begin{array}{c}1 \text { - iznimno } \\
\text { POZITIVNE okolnosti }\end{array}$ & 2 & 3 & 4 & 5 & 6 & 7 & 8 & $\begin{array}{c}9 \text { - iznimno } \\
\text { STRESNE okolnosti }\end{array}$ \\
\hline Odnos s partne & & & & & & & & & \\
\hline Obitelj & & & & & & & & & \\
\hline Prijatelji & & & & & & & & & \\
\hline Fakultet/posao & & & & & & & & & \\
\hline Financije & & & & & & & & & \\
\hline $\begin{array}{l}\text { Svakodnevne } \\
\text { neprilike (npr. } \\
\text { promet) }\end{array}$ & & & & & & & & & \\
\hline Životni uvjeti & & & & & & & & & \\
\hline Zdravlje & & & & & & & & & \\
\hline Stanje u državi & & & & & & & & & \\
\hline
\end{tabular}




\section{Sukobi u vezama_2}

8.

12. Pitanja koja slijede se odnose na Vaše osjećaje i misli tijekomPOSLJEDNJEG MJESECA. U svakom pitanju se traži od Vas da označite broj koji reprezentira KOLIKO ČESTO ste se osjećali ili razmišljali na određeni način. lako će Vam se možda činiti da su neka pitanja jako slična, postoji razlika među njima, pa Vas molimo da svako pitanje tretirate kao zasebno. Najbolji način rješavanja je bez puno razmišljanja o svakoj tvrdnji. To znači da se ne mučite brojati koliko ste se puta u posljednjih mjesec dana osjećali na određeni način, već da izaberete odgovor koji Vam se čini kao točna procjena učestalosti.

U posljednjih mjesec dana, koliko često ste bili uzrujani zbog
nečega što se dogodilo neočekivano?
U posljednjih mjesec dana, koliko često ste se osjećali kao da ne
možete kontrolirati važne događaje u Vašem životu?
U posljednjih mjesec dana, koliko često ste se osjećali nervozno
i “pod stresom"?
U posljednjih mjesec dana, koliko često ste se uspješno nosili
sa (svako)dnevnim problemima i brigama?
U posljednjih mjesec dana, koliko često ste osjećali da se
možete dobro nositi s važnim promjenama koje su se događale u
Vašem životu?

U posljednjih mjesec dana, koliko često ste se osjećali sigurni da se možete nositi s osobnim problemima?

U posljednjih mjesec dana, koliko često ste osjećali da se stvari odvijaju onako kako ste zamislili?

U posljednjih mjesec dana, koliko često ste osjećali da se ne možete nositi sa svim stvarima koje ste trebali učiniti?

Koliko ste često, u posljednjih mjesec dana, mogli kontrolirati događaje/situacije koji su Vas činili razdražljivima?

U posljednjih mjesec dana, koliko često ste osjećali da držite sve konce u svojim rukama?

Koliko ste često, u posljednjih mjesec dana, osjećali ljutnju zbog događaja koji su bili izvan Vaše kontrole?

Koliko ste često, u posljednjih mjesec dana, razmišljali o obavezama koje morati ispuniti?

Koliko ste često, u posljednjih mjesec dana, bili u mogućnosti kontrolirati način na koji provodite svoje vrijeme?

Koliko ste često, u posljednjih mjesec dana, osjećali da se poteškoće toliko gomilaju da in ne možete riješiti? 


\section{Sukobi u vezama_2}

9.

13. Pročitajte dobro sljedeće tvrdnje i uz svaku od njih odaberite onaj broj koji najbolje opisuje u kojoj se mjeri određena tvrdnja odnosi na Vas.

2 -

1 - potpuno djelomično 3 - ni točno netočno netočno

ni netočno
4 -

djelomično 5 - potpuno točno točno

Općenito govoreći zadovoljan/a sam sobom.

Želio/la bih imati više poštovanja prema samom/oj sebi.

Osjećam da nema puno toga čime bih se mogao/la ponositi.

Ponekad se osjećam potpuno beskorisnim/om.

Sposoban/a sam raditi i izvršavati zadatke podjednako uspješno kao i većina drugih ljudi.

S vremena na vrijeme osjećam da ništa ne vrijedim.

Osjećam da sam barem isto toliko sposoban/a koliko i drugi ljudi.

Osjećam da posjedujem niz vrijednih osobina.

Sve više dolazim do spoznaje da jako malo vrijedim.

Mislim da vrijedim barem koliko i drugi ljudi. 


\section{Sukobi u vezama_2}

10.

14. Pročitajte sljedeće tvrdnje i uz svaku od njih odaberite onaj broj koji najbolje opisuje u kojoj se mjeri određena tvrdnja odnosi na Vas.

1 - uopće se ne odnosi na mene
3 - podjednako se

odnosi i ne odnosi

2

na mene
4

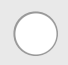

5 - u potpunosti se odnosi na mene

Lako se oduprem iskušenjima.

Teško mi je odviknuti se loših navika.

Lijen/a sam.

Znam izgovoriti

neprimjerene stvari.

Radim neke stvari koje nisu dobre za mene.

Ne prihvaćam stvari koje su loše za mene.

Volio/voljela bih imati više samodiscipline.

Ljudi bi za mene rekli da imam željeznu samodisciplinu.

Užitak i zabava me ponekad spriječe u tome da dovršim posao.

Teško mi je koncentrirati se.

Sposoban/a sam efikasno raditi na ostvarivanju dugoročnih ciljeva.

Ponekad se ne mogu zaustaviti, iako znam da radim nešto pogrešno.

Često napravim nešto bez da prije promislim o svim opcijama.

0

O

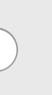




\section{Sukobi u vezama_2}

11.

15. Pročitajte sljedeće tvrdnje i označite koliko često ste se tako osjećaliU POSLJEDNJIH MJESEC DANA.

1 - uopće se

nisam tako

osjećao

Bio/la sam

zaokupljen drugim

stvarima osim ljubavnom

vezom.

\section{Osjećao/la sam se}

umorno.

Trebalo mi je mnogo snage volje da obavim

sve što trebam.
7 - skoro uvijek sam se tako osjećao

4

5

6

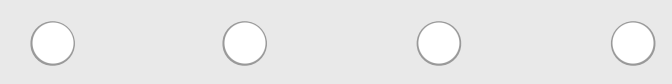

0
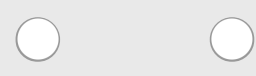


\section{9. ŽIVOTOPIS}

Tina Krznarić Jaković rođena je 1986. godine u Zagrebu. Preddiplomski studij psihologije na Filozofskom fakultetu u Zagrebu upisala je 2005. godine, a 2008. godine i diplomski studij. Diplomirala je 2010. godine na temu vremenske perspektive i rizičnih seksualnih ponašanja. Poslijediplomski doktorski studij psihologije upisala je 2013. godine.

Na Filozofskom fakultetu u Zagrebu se 2011. godine zapošljava kao vježbenica u Centru za primijenjenu psihologiju, nakon čega nastavlja surađivati s Centrom u svojstvu suradnice na tehnologijskom projektu Ministarstva znanosti, obrazovanja i sporta "Razvoj, standardizacija $i$ psihometrijska validacija testova kognitivnih sposobnosti". Sudjelovala je i na projektu "Odrednice aktivnog i pasivnog ponašanja u intimnoj vezi " pri Odsjeku za psihologiju Filozofskog fakulteta u Zagrebu. Tijekom 2015. godine prijavljuje projekt "Razvoj novog modela komunikacije prilikom sukoba u bliskim vezama", te se zapošljava na Filozofskom fakultetu u Zagrebu kao voditeljica navedenog projekta, financiranog od strane Europske unije. Tijekom 2016. boravila je u studijskom posjetu Lisbon University Institute na Odsjeku za društvena istraživanja i intervencije. Od 2011. godine vanjska je suradnica na kolegijima Psihologijski praktikum I, II i III na Filozofskom fakultetu u Zagrebu, a bila je i vanjska suradnica na kolegiju Komunikacijske vještine. Od 2016. održava vježbe iz kolegija Metodologija istraživanja u socijalnom radu na studiju socijalnog rada Pravnog fakulteta u Zagrebu.

Objavila je dva izvorna znanstvena članka u koautorstvu, te tri poglavlja u stručnim knjigama, a sudjelovala je s petnaestak izlaganja na domaćim i međunarodnim znanstvenim konferencijama. Završila je više edukacija i radionica iz područja psihologijskog testiranje, te ljetnu školu iz strukturalnog modeliranja u organizaciji European Consortium for Political Research. Završila je i osposobljavanje za voditelja izrade i provedbe projekta financiranih putem EU fondova. Članica je Hrvatskog psihološkog društva, Hrvatske psihološke komore i International Association for Relationship Research. 


\section{POPIS OBJAVLJENIH RADOVA}

Huić, A. Krznarić, T. i Kamenov, Ž. (2018). Time perspective, perceived stress, self-control and relationship satisfaction in heterosexual dating relationships of emerging adults. Psicologia, Revista da Associação Portuguesa Psicologia, 32(1); 63 - $78 . \quad$ DOI: 10.17575/rpsicol.v32i1.1327

Krznarić, T. (2017). Kako ne pojesti kolačić? Vremenske perspektive kod djece. U Salkičević, S., Huić, A., Parmač Kovačić, M., Rebernjak, B., (ur.) PsihoFESTOlogija 2: Psihologijska znanost na popularan način. Zagreb: FF Press (str. 165 - 169).

Krznarić, T. i Huić, A. (2015). Jeste li ispred svog vremena? Važnost vremenskih perspektiva za svakodnevni život. U M. Tonković-Grabovac, U. Mikac i T. Vukasović Hlupić (ur.) Psihofestologija - ovo nije samo još jedna knjiga iz popularne psihologije. Zagreb: Odsjek za psihologiju Filozofskog fakulteta Sveučilišta u Zagrebu (str. 40-44).

Krznarić, T. i Kamenov, Ž. (2017). Kako se dobro posvađati? Komunikacija prilikom sukoba u ljubavnoj vezi. U Salkičević, S., Huić, A., Parmač Kovačić, M., Rebernjak, B. (ur.) PsihoFESTOlogija 2: Psihologijska znanost na popularan način. Zagreb: FF Press (str. 101 $-105)$.

Krznarić, T. i Kamenov, Ž. (2016). Attributions of partner's negative behavior and intimate relationship quality. Socijalna psihijatrija, 44(4); 283-290. 